\title{
SIMPLE HOLOCARPIC BIFLAGELLATE PHYCOMYCETES
}

\author{
JOHN S. KARLING
}

Columbia University 


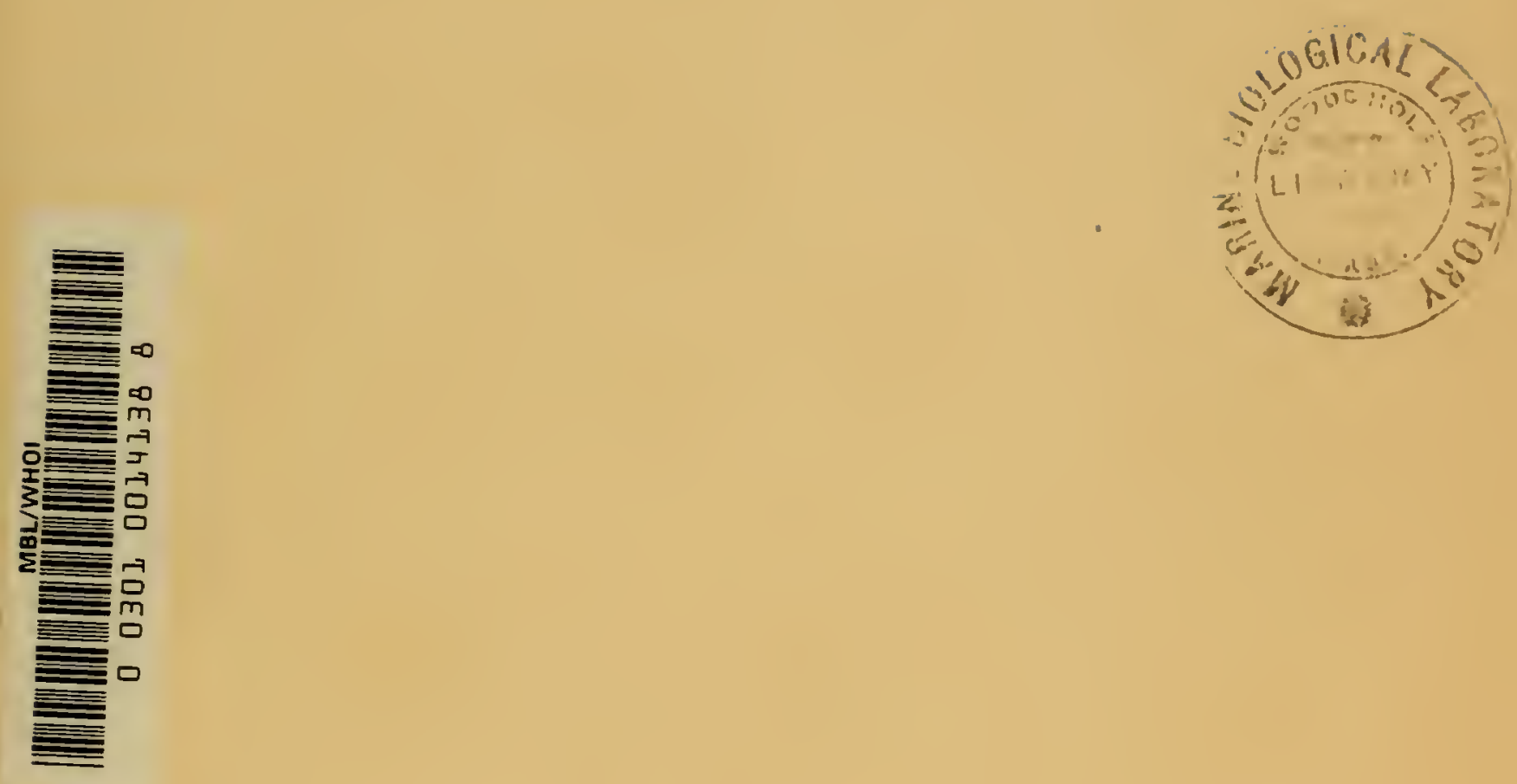





\title{
THE SIMPLE HOLOCARPIC BIFLAGELLATE PHYCOMYCETES
}

\author{
Including a \\ Complete Host Index and Bibliography
}

BI

JOHN S. KARLING

Columbia Lniverity

First Eutriox

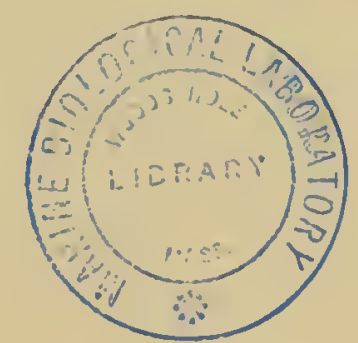

PUBLISHED BY THE AUTHOR

NEW YORK CITY 
COPYRIGHT, 1943, BY THE AUTHOR.

ALL RIGHTS RESERVED. THIS BOOK, OR PARTS

THEREOF, MAY NOT BE REPRODUCED IN ANY

FORM WITHOUT PERMISSION OF THE AUTHOR. 
Dedicated to the Memories of

SCHENK, CORNU, AND ZOPF

For their Contributions to the

Knowledge of the Lower Fungi

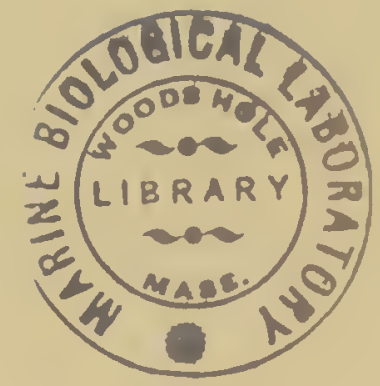



Tus suste volume on the simple. holocarpic hiHagrellate Phyeomycetes is the second in a series of lecetures presented to erraluate and researeh students of mycology at Columbia University on the origin, development, phylogeny, and evolution of the lower organisms. 'Phese simple Plyyomyetes, with the exception of the Lagenidiaceace. Were formerly incluled in the Chytridiales by most myeologists, lont with the recognition in recent decarles that the number. position. and relative lengths of the flagella are of fundomental phylogenetic significance. the vicwpoint has gradually developed that these species camot be ineorporated in the same order with the posteriorly unitlagellate clytrisly. On the hasis of present-day evidenee, the author concurs with this helic and is accordingly presenting these biflagellate species apart from the elytrids. Many of these simple fungi exlibit distinct oomycetons characters and tendencies and should perhaps be included directly in existing or new families of the Phycomyectes. while the life eycles of other species suggest a relationslip or at least a parallelism in development with the Plasmodiophorales and Protcomya. It is thus impossible at present to include all of them in one fomily or order and very difficult to assign them to a definite position in a natural system of classification. For this reason they are treated separately and are referred to here is a heterogeneous collection of simple, holocarpic, hiflagellate l'hycomycetes. This long title is olvionsly inadequate and can also be extended to include other l'hyeomycetes not diseused here, the thalli of which may sometimes be holocarpic. A more adequate and briefer title is not arailalle, although the descriptive name Holobiflagellonyetes is suggested. The use of the term "simple." is not to he interpreted as meaning that these fungi are primitive and have given rise direetly to the higher Oomyeetes and Zygomycetes. Nor loes the author wish to conver the impression that ly diseussing these diverse fungi under one title that lie consiclers them as constituting a natural phylogenetic series. Whether or not they comprise several distinct families is ohviously open to question. The fanily Worminaceae, for eximple, inelules several disimilar genera and is rery doubtful. should the type species Horonina polycystis prove to he a member of the Plasmodioplorales, ats secms quite likely at present. the former family name woulal no longer be tenable. 'l'he author has nonetheles grouperl the genera in five families, realizing fully that the grounds for doing so are woefully inarlequate. Mycologists will doubtless disagree with this arrangement, hut in our stite of meager knowledge eonecroning many of the genera and speries. classification into families is not so important at present, in the author's opinion, as making avaliable to researel students all known facts and datil.

'Tlhese fungi have been the subject of stud! for almost a eentury but no serious attempt has been made to summarize the widely seattered data in zoologrical and hotanieal journals. Fischer ('y2), Sehroeter ('97), and Minelen ('11) discussed rather fully the species known at the turn of the eentury, but since that time most texthooks of mycology have eriven scant attention to them. During the past two deceades several new genera and species have been discovered, and adelitional intensive studies on loner known speeies have modified our eoncepts of host range, sexuality, relationships, ete., within the group. In light of these discoveries and the fact that these simple holocarpic fungi are so signiticant from the standpoints of phylogeny and evolution of the higher Phycomyeetes. the anthor helieves that a scparate and complete treatment of them is wry essential and worthwhile, partieularly in stimulating research. A full discussion of the doulttul and excluded species is also presented with the purpose of making these data available to research workers. Althongh the author agrees with the view that . Ichlyogeton, so far as it is now known, shonld he excluded because of its reported posteriorly uniflagellate zoospores. he novertheless believes it may possibly prove to be a valid member of the group.

In the text which follows very few technical terms are used. A glossary is accordingly mneeessary and has been omitted. Separate hiblingraphice are provided at the end of each chapter to expedite reference to the literature on particular subjects. genera, and species. A host index of plant and animal grenera and species, together with an inclusive billiograplyy is presented in the final eloapter. I) ue to war conditions, many of the recent European and Asiatic journals have not heen availahle, so that this index and bibliograplyy nay not be complete. 'l'he illustrations of numerous authors in Americal and other parts of the world have been freely used hy the anthor. (irateful thanks for this courtesy is lierehy expressed to them. These entributors are too numerous for individual mention, bat full creelit for their drawings is given in the descriptions of the plate's.

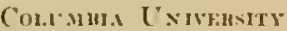

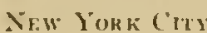

Ocronks, 191? 


\section{CONTENTS}

l'reface

\section{CHAP'TER I}

Introduction

Bibliography

\section{CHAP'TER II}

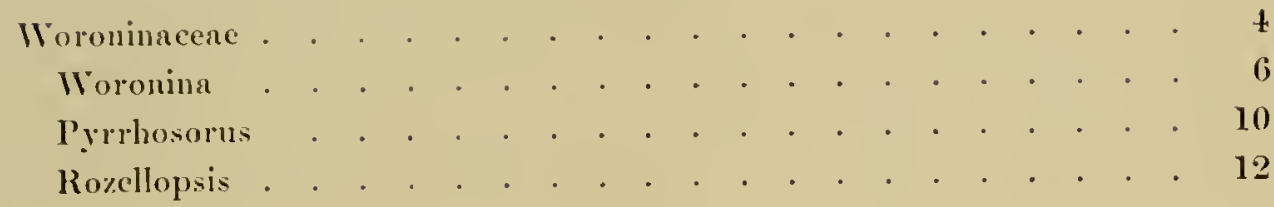

\section{CHAP'TER III}

Ectrogellacene . . . . . . . . . . . . . . . 17

Ectrogella . . . . . . . . . . . . . . . . 17

Eurychasma . . . . . . . . . • . . . . . . . . . 22

Eurpchasmidium . . . . . . . . . . . . . . . . 24

Aphanomycopsis . . . . . . . . . . . . . . . . . 28

\section{CHAPTER IV}

Olpidiopsidncene . . . . . . . . . . . . . . . . 31

Olpidiopsis . . . . . . . . . . . . . . . . . . 31

Development of thalli and roosporangia . . . . . . . . . 33

Resting spore development and sex differentiation . . . . . . 38

Cellular relations betwecn host and parasite . . . . . . . . to

l'arasites of Saprolegnia . . . . . . . . . . . . . . 41

Parasites of Aellya . . . . . . . . . . . . . . . . 45

Parasites of 1 phanomyges . . . . . . . . . . . . . 47

Parasites of Pythium . . . . . . . . . . . . . . . 47

Parasites of algac . . . . . . . . . . . . . . 48

Parasites of cryptogams and insects . . . . . . . . . . 52

Pseudolpidium . . . . . . . . . . . . . . . . . . 52

P'scudosplacrita . . . . . . . . . . . . . . . . . 55

Blastulidiopsis . . . . . . . . . . . . . . . . 58

Pythiella . . . . . . . . . . . . . . . . . . . 58 


\section{CHAP'TER I}

Sirolpidiaceae . . . . . . . . . . . . . . . . . . . 63

Silolpidium . . . . . . . . . . . . . . . . . . . 63

Pontisma . . . . . . . . . . . . . . . . . . . . 63

Petersenia . . . . . . . . . . . . . . . . 66

\section{CHAPTER V'I}

Lagenidiaceae . . . . . . . . . . . . . . . . . . .

Lagenidium . . . . . . . . . . . . . . . . .

Lagenidiopsis . . . . . . . . . . . . . . . . . . 11

Myzocytium . . . . . . . . . . . . . . . . . . 83

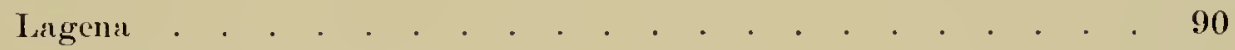

Doubtful genera . . . . . . . . . . . . . . . . . . . . . . 92

Resticularia . . . . . . . . . . . . . . . . . . 92

Fxcluderl genera . . . . . . . . . . . . . . . . 9t

Achlyogeton . . . . . . . . . . . . . . . . 94

Protascus . . . . . . . . . . . . . . . . . . . 96

Mitochytridium . . . . . . . . . . . . . . . . . 98

Rhizomyxa . . . . . . . . . . . . . . . . . . . 98

\section{CHAPTER VII}

Phylogeny and relationships . . . . . . . . . . . . . . 100

Woroninaceae . . . . . . . . . . . . . . . 100

Woronina . . . . . . . . . . . . . . . . . . . 100

Pyrrhosorus . . . . . . . . . . . . . . . . 101

Rozellopsis . . . . . . . . . . . . . . . . . . 101

Ectrogellaccae . . . . . . . . . . . . . . . . . 102

Sirolpidiaceate . . . . . . . . . . . . . . . 104

Olpidiopsidaceac . . . . . . . . . . . . . . . 104

Lagenidiacene . . . . . . . . . . . . . . . . 105

Hosts and Bibliography . . . . . . . . . . . . . . 108

Plant hosts . . . . . . . . . . . . . . . . 108

Fungi . . . . . . . . . . . . . . . . . . . . 108

Olpidiaceae . . . . . . . . . . . . . . . . 108

Saprolegniaceae . . . . . . . . . . . . . . 108

Pythiaceae . . . . . . . . . . . . . . . . 111

Nucoracease . . . . . . . . . . . . . . . . 111 
Myxoplyecre

()coillntoriacose

seytonemalcease

Heterotiontare

Tribonemacese

creptomonaducene

Eugremecae

Dinotlacellat a 111

Peridiniacene

Diatoms.

111

Bacillariaceac

Chloropliycese 113

Chlamydomonadacease . . . . . . . . . . . 113

zyanemacerse.

Desmillaceac $11+$

Chactophoraceate

Oedogoniascease

Cladophoraceac

Bryopsidaceace

Vaucheriaceace 116

Characeace 116

Phacophyerese 116

Ectociaparcate

Rhodophyegere

Coramiatere

Rhodymeniaceac

116

Rhodophyllidiaceace

Jiverworts

Riceriaceate

Enidentified speeries.

Gymnosperms: 117

pinaceac

Angriosperms

Gramineate

Solanaceate

Caryoplypllaceac

Infus(u)

Rotritoria

Sematoda

1)iptera 
Species Index

Subject Index

Author Index 


\section{Introduction}

TuF Foxar presented herewith as the simple. holocarpice hiflagellate Phyconycetes comprise a heterogeneons collection of approximately eighty speries which at re characterized by relatively small or reduced. loolocitrpie thalli and biflageliate zoospores. Although these characters are common to all members of the group) present day evidence does not fully warrant the inclusion of these speejes in one colerent family or order. The simple species were formerly included by most mycologists in the family Woroninaecae and plaecd among the Chrtridiales. while the clongate. nowe myeclioid memiers were incorporated in the Iagenidiaceae and regarded as elonely related to the Saprolegniaceae and Pythiaceate. Inasmueh as the Chytridiales are eharacterized hy posteriorly uniflagellate zoospores, the members of the Woroninaceae ean no longer be ineluded in this order as it is now recognized. For this reason these biflagellate speeies as well as the Lagenidiaceac are deseribed apart from the ehytrids. As will become evident below, they do not constitute a well-defined order or fanily and it is accordingly impossible to give the group as a whole a distinctive name. They are thus presented as simple. holocarjice hiflagellate Plyeomyectes. The majority of them are Oomycete-like and appsear to be either simple and primitive or redueed and degenerate Oonycetes, hut since some species are reported to lie isoganous. like the Zygomycetes, they must for the time being be listed under the more general term l'lyconyeetes. Further study of known speeies and the discovery of new ones will doubtless invalidate many of the present day eoneepts concerning their phylogeny and relationships, and it is not improballe that they may eventually be ineluded in existing fanilies and orders of the Oomyeetes and Zygomyetes.

Whether or not the known genera and species comprise several distinct and elearly defined families is not at all certain at the present time. "The critical derelopmental stages of many speceses are unkunw. and the limits of the geinera are not sharply defined. Nevertheless as an aid in classification and an experlient of reference, they lave been Erouped into five families on the hasis of thallus structure and metlod of sexual reproduction. The. structure of the vegetative thallus al lone is obviously of questionable diagrostic value. but in species where resting spores and sexual reprocluction are muknown. it is the only hasis of distinction for the present. "Tlue orier in which the fanilies are presented does not always indieate degree of conplexity. phylogenetic relationship, and evolution. The jorovisional fanily Woroninacease is presented first lnecaum of its plasmorlium-like thasllus and otlece structural similarities it has in the Plasmodiophorales, but the second fintly. Foctrogellaceac, s lo ow s distinct saprolegniaceous characteristies by its diplanctir zospores. How closely this fimily is related to the Saprolgeniales cannot be aseertained at present. because so little is known ahout its resting spores or the arcurrence of sexuality. The Olpidiopsidacene should perhaps be placed nest to the Iagenidiaerae berause of its predominantly heterogamous type of sexual reproduction. 'The Sirolpidiaceac', however, is placed in this relative position because its thallus has a tendency to become elongate, filamentous. myeelioid and fragmented like that of some species of Lagenidium and Myzocytium. On the other hand, its thallus may sometimes be reduced and distinctly olpidioid. The occurrence of such thalli and the fact that nothing is known about the tyje of sexual reproduction makes the position of this family next to the Iagenidiaccae very problematical. The Lalgenidiacene ap)pears to be the most complex as far as thallus structure and methol of sexual reproduction are concerned and is accordingly presented as the highest family in the evolutionary series. In most species the thillus is elongate and of ten distinetly mycelioid, but it may also be redued, unicellular, and olpidioid. However, the resting spores or oospores are usually developed in partially or fairly well differentiated oogmia as in the higher Oomycetes.

The simpler, olpidioid species were discovered shortly beforc the middie of the last century. Although they had probably been observed earlier. Niageli ('t. f) was among the first to describe and illustrate them as globular bodies in the myeelium of wiater molds. hut lie mistook them for a piart of the normal life eycle of the host. Cicnkowski ('55) likewise misinterpreted the parasites which he fouml in Achlya prolifera as a thirl type of sporangia dereloped hy this host, but in the same vear the paritsitic nature of these int ramatrical bodies was clearly recognized by Alexander Braun. The speeies which lo described in Saprolegnia ferax is now lelieved to relate to Olpidiopsis Saprolegniae. He named this parasite Chytridium Saproleyniae and placed it in his sub-genus Olpidium of the (hytrieliaceate. 'Thus. at all carly stage these Olpidiopsis parasites became associated with the elyytrids in mycolosical literature. and this fact together with the'ir striking similarity of thallus structure and type of development to that of the olpidiend chytrids are probially the chicf reisons why most morologrists up to the present time have ineduded the'n in the Chytridiales. Despite Braun's excellent study. P'ringsheim ('60) was still doulut ful about the nature of these parasites and believerl that they might possibly be the antheri- 
dia of Saprolegnia. However, an intensive study by Cormu in 1872 settled forever the question of whether they are parasites or relate to the life eyele of the host. He proved eonclusivcly their parasitic nature and established the genera Olpidiopsis and IForonina for the biflagellate species which oeeur in lehlya, A phanom yces, and Saprolegnia. Like Braun he ineluded these parasites in the Chytridiales. Cormu observed that the resting spores were usually accompanied by one or more attached, thin-walled. empty resieles whieh he assumed to be male eells or antheridia. In 1878 Reinseh observed the passage of the protoplasm of the small eell into the larger one, and since that time the resting spores have been generally regarded as zygotie in origin. Cornu aud Reinsel ohservations were followed by the early studies of Fiseher whieh contributed muel to our knowledge of the developmental pliases of these fungi. His observations and eonelusions were nevertheless incorreet aud eonfusing in several respects. and it was not unti] 1892 that he eorreeted some of lis errors. Subsequent students of these olpidioid parasites, including Zopf (' 84 ), Sehroeter (' 86 . '97). Petersen ('09, '10), Minden ('11), and others, eontinued to inelude them in the Myroehytridiales, although Lotsy ('07) and Vuillemin ('08) emphasized that the so-ealled elyytrids with liflagellate zoospores have a different origin from those with unifiagellate zoospores and should be sharply separated from the latter. 'These differenees were elearly recognized hy Seherffel in 1925, who for the first time removed Olpidiopsis and similar genera from the Chytridiales and placed them at the lottom of a Saprolegniales-Peronosporales series. Seherffel's interpretation has been followed by a few myeologists, particularly Weston ('35, '41) and Sparrow ('35, i2).

In the meantine, while data about the simple olpidioid parasites were aeeumulating, extensive studies had been made on the more complex, elongate and mycelioid speeies at the other end of the series. In the group now known as the Lagenidiaceae the genera $M y z o c y t i u m$ and Lagenidium were diseovered and created by Sehenk in 1858 and 1859. Beeause of their elongate thalli and the faet that the zoospores may be formed in a thin, extramatrieal resiele, these speeies were first regarded as memhers of the genus P'ythium ly Selienk, Pringshcim ('58. ' 60 ), and $\mathrm{WaIz}$ ('70), althougl it was not then known that the zoospores are biflagellate. These workers figured and deseribed the zoospores as miflagellate, but the subsequent studies of Zopf (' 78 , '79, ' 84, ' 87 ) proved the presenee of two flagella as well as the faet that sexual reproduction in many of the speeies is heterogamous. These diseoverics eoupled with the association of $M y \approx o c y t i u m$ and Lagenidium species with Pythium in myeologica] literature empliasized their relationshijs to the ligher filamentous Oomycetes, and the lagenidia"eac were accordingly never included directly in the Chytridiales. Most myeologists have subsequently ineorporated this family with the Saprolegniales. Since the time of Zopf several unicellular, olpidioid speeies of Myzocytium and Lagenidium have becn diseovered. the thalli of which are strikingly similar to those of Olpidiopsis, so that the gap between the Olpidiopsidaceae and the elongate myeelioid members of the Lagenidiaceae has heen bridged as far as thallus strueture is eoneerncd.

These simple Plyconyeetes are fairly eommon in nature and almost world wide in distribution. So far they have heen reported from Europe, Asia, and Nortl, Ameriea, and when more extensive studies are made they will doubtless be found to oeeur in Afriea and Australia also. They are ubiquitous in host range and oceur in diatoms, blue green, green, brown, and red algae, fungi. liverworts, mosses, grmnosperms, and angiosperms. Among animal hosts they have been rejorted in infusoria, rotifers. nematodes, weevils, mosquitoes, copepods and erustacenus. 'They are predominantly aquatie and may oecur in marine as well as fresh water. Most speeies of the families Ectrogellaeeae and Sirolpidiaceae parasitize marine algae. The majority of speeies are parasitie and eventually kill their hosts, while othcrs are weakly parasitic or saprophytic. Ohligate parasitism has been reported for a few speeies. They may eause marked reaetions in their hosts whieh involve inereased eell division and enlargement and lead to gall formation. Other speeies merely kill and absorb nost of the eontents of the lost eells. Only one species appears to be of eeonomie signitieance. Lagena radicicola in eonjunetion with otlier fungi eauses a root disease of wheat, barley, rye, and eorn whieh is elraraeterized hy stunted curved roots and a reduetion in the root system as a whole. The stems of infeeted plants are considerably shorter than those of normal individuals, while the leares may heeome pale-green and lighter in eolor and under eertain eonditions slow "browning symptons."

Sinee several of these speeics do not appear to be elosely related, differenees in types of development are to be expected, and it is inpossible to give an introduetory aeeount whieh will apply to all families and genera. In the family Woroninaceae, as it is here interpreted, the vegetative assimilative thallus has been deserihed as a jlasmodium whieh undergoes eleavage at maturity. The segments thus formed may develop either into zoosporangia or resting spores. The former may he united in a sporangiosorus or lie free, and give rise to zoospores which are discharged to the outside and reinfect the host. The resting sjores whenever formed usually appear as the fungus eulture hecomes older ind

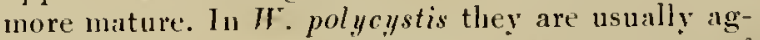
gregated in compact eystosori as in some genera of the Plasmodioplorales, while in other speeies they lie loose and free. Like the sporangia, they form zoospores in germination. Neither zoosporangia nor resting spores have been observed in I'yrrhosorus. The spore mother eells whieh eomprise the sorus divide three times to form eiglit free, thin-walled 
vanres. and these are soun transfomed directly into zouvmon. withent goviner through a dormant period. lit the polyporangiate species of liozellopsis the seguents of the plasmodium form either \%ousposringia or resting spores. lut unlike in $/ T^{\circ}$ oronina they lucoune separated by septa which the host cell forms. Is a result, neitleer sporangia ner restiug upures are united in sporangio- and rystasori, respectively. ln the momesporimgriate speres of this genus coleavige of the thallus apparently does not accur. since enels infection is reported to grive rise to

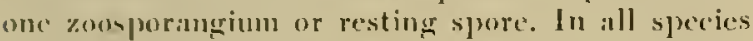
of the Ilorominaceale. however, the zoospores eneyst fempurarily an thes surface of the host and form during eremination a pencetration tube througl which the ypore eoutent palase's into the host cell as a naked proteplast. Devertheless. marked difterences in type of development oceur in this provisional family which rearly indicate that the generic and family conecepti are inadcepuate. The resting spores in all threc senera appear to he asexual, since no fusion of anmetes has heen observed duriner their formation.

lit the sccoud family. Ectrogcllaceate. no plasmodium acours. and each zouspore gives rise to one zoospormgium or resting spore. The zoospores of this family, however. exhibit true diplanetism like those of ichlya and other gevera of the saprolegniales. Resting spores are known in only two specice of this family. In E. perforans they are asexual or possilly parthenogenetic. while in $k$. Licomophoras they lave been reported to be aygotie by Seherffel ( 2,5$)$. lut the cridence of sexuality in this speeies is not conelusive. The family Olpidiopsidaceae includes approximately thirto speries whieh have the same type of regetative development as thone of the Eetrogellasecae. In some species of Olpidiopsis the zoosjures exhilit what has been descriled as partial and primitive diplanetism, while in (). Ocelogoniorum and "ythiella zernalis the $y$ are typically diplanetie. Well defined sexuality oceurs in a large number of members of this family. At the close of the regetative period in Olpidiopsis fusion letween thalli of uncqual. and rarely of equal. size occurs whicll results in the formation of a thickwalled \%rgote. 'These thalli are generally deserilued as oogonia and antheridia on the hasis of rolative sizc. lut they are not markedly differentiated as fametangia or rauces. Sonctheless. the evolution and differentiation of such gancetangia and henterogamy are foresladowed in Olpidiopsis. "The degree of iexuality varies consideralsly in this genns. Some species are wholly sexual or jarthenogenetic while others are partialiy so and form only a few zyegoten. In Pythiella au egge ecll or oos] uhere with a trace of periplasu is formed in the oogonium apparently an advance in lecterngamy toward the Pythium type. Sufar as is now known, the developument of the thallus in the sirolpidiaceac is similar to that of the Ectrogellaceae and Olpidiopsidacene with the r. $x$ (e)ption that it may locenne more clomgate and filamentous and undergo segucentation. Flie serencents thus formed may separite and are transformed directly into olpidioid zomsporangia. 'l'he acourremese of resting spore's is moknown or at least rery dombtful in this fanty and no cridence of sexuality has been reprorted.

In the family Lagenidiaceac the content ol the zompore does not enter the lusst as a naked amocboid horly. lut the tip of the ererm tube clongates, conlarges, and eventually developes into the mature thallus. In the majority of species the thallus is elomerate. sebtate, and may become distinctly myeclioisl. Reduced uniecllular. olpidiod thalli, however, are not mneommon. In some species the segments of the thallus may separate as in the Sirolpidiaceat. 'The segments are transformed cither into zoosporingia or gametangia and botl types of reproduetive struetmes may be intermingled in the same thallus. The zoospores may be fully developed in the zoosporangia and swim dircetly away after emerging or are only partly formed in sporangia and undergo further development in an extramatrical vesiele. In other species the content of the sporangiun emerges to the outside as a naked protoplasmie mass and undergoes eleavage into zoospores in muel the sane manner as in Pythium. 'The presence of a resicular nembrane aromd the protoplasmie mass and the zoospores which are subsequently formed has heen reported in a number of speeies lut appears to be lacking in otluers. In sone species the zoospores encyst in a mass at the mouth of the exit tube and exhibit marked diplanetism. Sexual reproduction in this family is predominantly heterogamous, but in Lagenidium sacculoides, Lagena radicicola, and Resticularia modosa it is rejorted to be isoganous. The segments of elongate thalli as well as entire redueed uniecllular thalli which function as gametingia are only slightly or not at all differentiated as sexual organs. The female grametangiun or oogonium. however, is nunally larger, more vesicular, and frequently barrel-shaped, while the socalled antheridium is nsmally clongate and tubular. Differcutiation of an egar eell and periplasm in the fumale gametangium has not heen conclusivcly demonstrated, but the onplasm may contract and agreregate toward the conjugation tube or pore during jasmogamy. The zvate which results from fusion lies free in the oogonimn and is generally referred to in the literature as an oospore. In some specicen the antleridium is lacking, and the resting spores are formed partlonogenetically.

\section{BIILIOGIRAIIIY: INTHODE"C"TION}

Braun, A. 18.jiat. Ber K"gl. J'rousti. Akad. Wiss, ] h.j.s: 36,j.

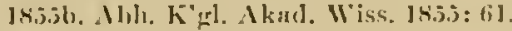

Cicukumaki, 1.. 18.5.j, Bul. \%,cit. I3: 801.

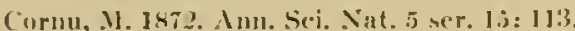

Fiscluer, A. 18k0. But. \%,it. 36: tik9.

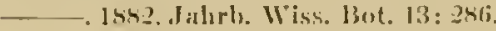

1492. Kubuluest's Krypt'A. 1, 1:37.

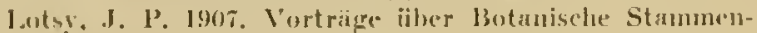
zescluichle 1. Jena. 
Minden, M. 1911. Krypt'fl. Mark Brandenburg 5: 262.

Nägeli, C. 1844. Zeitschr. Wiss. Bot. no, 1, 3 : 29.2.

Petersen, H. F. I909. Bot. Tidsskr. 29. 1910. Ann. Mycol. 8: 539.

Pringsheim, N. 1858. Jahrb. Wiss. Bot. $1: 284$.

1860. Ihid. 2: 205 .

Reinsch, P. 1878. Ibid. 11 : 283.

Schenk, A. 1858. Üher das Vorkommen Contractiler Zellen im Pflaazenreich. Wurzlurg.

___ 1859. Verh. Phys. Med. Gesell. Wurzburg 9: 27.

Scherffel, A. 19:5. Arch. Protistk. 5:38.

Schroeter, J. 1886. Colun's Krypt'fl. Schlesiens 3: 195.

85.
Sparrow, F. K. 1935. Proc. 6th Intern. Bot. Congress 11: 182.

1942. Aycologia 34: 113.

Vuillemin, P. 1908. Prog. rei Bot. Q: 1.

Walz, J. 1870. Bot. Zeit. 28: 556.

Weston, W. H. 1935. Proc. 6th Intern. Bot. Congress 1: 266.

- 1941. Symposium on Hydrobiology, 1) 130. Univ. of Wisconsin Press.

Zojf, W. 1878. Verh. Bot. Verein. Brandenburg 20: 77. 1879. Hedwigia $18: 94$.

. 1884. Nova Acta Kisl. Leop.-Carol. Deut. Akad. Nat. 47: 143.

1887. Abl. Naturf. Gesell. Halle 17: 97.

\section{Chapter II}

\section{Woroninaceae}

\section{Minden, 1911. Krypt. Fl. Mark Brandenburg 5: 224.}

This family was proposed by Minden for all simple holocarpic species, exclusive of the Lagenidiacea, which had been reported to have biflagellate zoospores, and as such it included Olpidiopsis, Pseudolpidium, Woronina, and Rozella. Minden placed this family in the Cliytridiales, and together with the Olpidiaceae and Synchytriaceae it comprised the socalled Myxochytridiales of Fischer. In creating the Woroninaceae, Minden ignored Petersen's ('09) earlier-named family Pseudolpidiaceae which was proposed for Olpidiopsis and Pseudolpidium. Since Minden's time numerous other genera lave been added to the Woroninaceae, and this family las been rather generally regarded as a convenient dumping ground in the Chytridiales for fungi of this type with hiflagellate zoospores, although Petersen and Scherffel in particular emphasized the similarity and relationships of such fungi to the Lagenidiales and Saprolegniales. Sparrow ('42) discarded the family name Woroninaceae entirely, presumably because he believed that the genus Woronina, after which the family takes its name, belongs in the Plasnodiophorales. While the data at hand favor the view that $W^{\prime}$. polycystis, at least, is a nember of this order, further intensive study of Horonina is nceded hefore this question can be settled. Until this relationship is estahlished. the present author is temporarily retaining the Woroninaceae in a restricted sense for Woronina, Pyrrhosorus and Rozellopsis. By this interpretation it is not, lowever, to be regarded as a well established and unquestionable family of closely related genera, but still as a convenient catch-ali for species which are reported to have a plasmodial vegetative stage but which at present cannot be definitcly inclucled in the Plasnodiophorales. In Woronina, I'yrrhosorus, and the septigenous species of Rozcllopsis the plasmodium is reported to undergo segmentation into a number of elosely aggregated or loose and separate spores, spore mother cells, sporangia, or resting spores, and the suggestion is obvious that such species may possibly be transition forms between the Plasmodiophorales and the non-plasmodial, non-soric genera. However, our knowledge relative to both groups is

PLATE 1

\section{Joronine polycystis}

Figs. 1, ९. 13iflagellate zoospores. Fischer, ' 8 ?.

Figs. 3, 4. Anteriorly biflagellate zoospores. Cook and Nicholson, "33.

Figs. 5, 6. Early infection stages. Fischer, l.c.

Fig. 7. Same. Cook and Nicholson, l.c.

Figs. 8-10. Amoeboid changes in shape and position of young parasite in lost cell. Fischer, l.c.

Figs. 11, 12, 13, 15. Successive stages in development of the parasite and its cleavage into a sporangiosorus. Note local hypertrophy and septation of host lypha. Fischer, I.e.

Fig. 14. Vacuolite thallus undergoing centrifugal clcavage. Fischer, l.c.

Fig. 16. Sporangiosorus. Cornu, '79.

Figs. 17-20. Itaturation, cleavage, and emission of zoospores from a sporangium. Fischer, l.c.

Fig. 2l. Small (m)lty sporangiosorus. Cornu, ].c.

Fig. 22. Cleavage of thallus into a cystosorus. Fischer, l.c.

Fig. 23. Nature eystosorus. Cornu, l.c.

Fig. 24. Scptate. locally hypertrophied Jypha of Saprolegnice with five cystosori of various sizes and slaajes and two empty sporangiosori. Fischer, l.c.

Fig. 25. Elongate, irregular cystosorus. Cook and Nicholson, l.c.

Fig. 26. Varionsly-shaped resting spores from a cystosorus. Fischer, I.c.

Figs. 27, 28. Thick-walled resting sporcs. Conk and Nicholson, l.c.

Fig. 29. Germination of cystosurus. Resting spores swelling and resiculating to become zoosporangia. Fischer, l.c.

Fig. 30. Gurmination of resting spores. Cook and Nicholson, l.c. 
PLATE 1
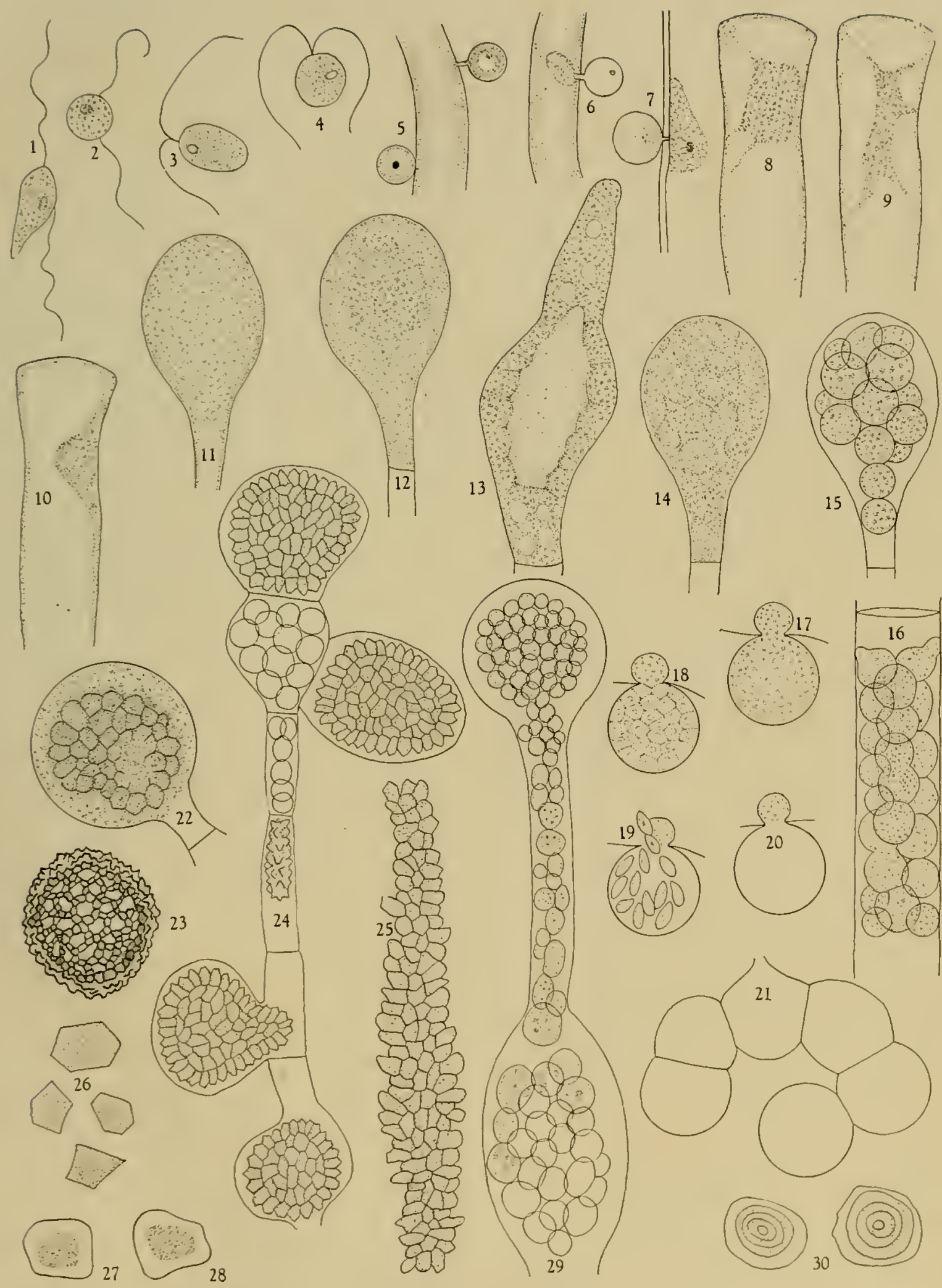
so incomplete at present that this suggested relationship is largely lypothetical.

\section{WORONINA}

Cornu, 1872. Ann. Sci. Nat. 5 ser. 15: 176. (Plates 1 AND 2)

Thallus intramatrical. plasnodial, naked but inmiscible with the host protoplasin; cleaving into segments which become zoosporangia or resting spores. Zoosporangia and resting spores united in compact sporangiosori and cystosori respectively, or lying loose and free of each other. Zoosporangia usuilly spherical, oval or ellipsoid with a short exit papilla or an elongate cylindrical and basally inflated exit tube. Zoospore pyriform or somewhat kidney-shaped with one to several refractive granules, heterocont (?): emerging singly and fully formed; occasionally liberated within the host ccll; swimming directly away in a comparatively slow and even manner. Resting spores spherical, oval, irregular and polygonal, with a smooth, spiny or sculptured outer wall ; producing one or sereral zoospores dircetly in germination.

This genus has been fully discussed by the writer ('42) in relation to the plyylogeny and relationships of the Plasmodiophorales. It includes at present five species most of which are incompletely known and very doubtful, and in light of present-day knowledge Woronina appears to be scarcely more than a dumping ground for species with a plasmodial stage which cannot be incorporated with certainty at present in the Plasmodiophorales or Proteomyxa. The type species. $W$. polycystis, has a life cycle almost identical to that of Octomyxa of the Plasmodioploraceac, while $\Pi$. glomerata resembles species of the zoosporic Myxozoidia or Proteomyxa by its animal type of nutrition. As a consequence these two species have been included in the Plasmodiophorales (Sparrow, '42) and the Proteomyxa (Zopf, '94; Scherffel, '25) respectively. The other species, $\boldsymbol{H}$. aggregata, $W^{r}$. elegans, and $W^{r}$. asterina, are so imperfectly known that it is impossible to determine their taxonomic and generic distinctions. Woronina must accordingly be interpreted for the time heing as a incolerent and questionable group of species. It is nonetheless phylogenetically significant, because it includes organisms which appear to he transitional forms hetween the Proteonyxa, Plasmodiophorales, and simple, holocarpic biflagellate oonycete-like fungi. Numerous undiscovered Toronina-like species doubtless exist, the discovery of which may possibly bridge the present-day gajs.

Sparrow ('42) disposed of $W^{\prime}$ oronina directly by including it in the Plasmodiophorales without presenting additional evidence of its relationslip to this order, but this disposition merely overlooks and does not elear up the problems involved. Horonina polycystis will prohably prove to be a plasmodio- phoraceous species closely related to Octomyxa Achlyae, and in that event some of the remaining species must be segregated in another genus. Woronina glomerata may well be a member of the Proteomyxa as Zopf and Scherffel contended, but further study is necessary to settle this point.

Inasmuch as these two species differ in certain respects their development will be described separately. In $\mathrm{W}$. polycystis the contents of the zoospore enters the host hypha as a naked protoplasmic mass (Pl. 1, figs. 6-10), undergoes amoehoid changes in shape, develops into a plasmodium-like thallus as it feeds on the host protoplasm, and causes local hypertrophy (figs. 11, 12).

At maturity the thallus cleaves into segments (figs. 13, 14) which develop into zoosporangia (figs. $15,16)$ and form a typical sporangiosorus. As in Octomyra, the peripheral zoosporangia are usnally independent with a single cxit papillae, while the deeper lying ones may be confluent with a common papilla for zoospore emission. Each sporangium produces a number of biflagellate zoospores (figs. 18, 19) which reinfect the host hyphae. As the culture becomes older, the nature thalli cleave into small segments which become the resting spores. These remain closely attached and form compact cystosori of various sizes and shapes (figs. 23-25). As in Ligniera and Polymyxa, the cystosori may be elongate, irregular, flattened, oval and almost spherical, and include a few to numerous polygonal spores, each of which produces one zoosporc in germination.

As to the structure of the zoospores there is, however, considerable disagreement among students of this species. Fischer described and figured them as ellipsoid (fig. 1) with a slight indentation at one side and two slightly unequal flagella. The shorter flagelhum arises from the anterior end and extends forward in swimming, while the longer one is inserted laterally and projects backward. It must be noted, however, that Fischer's description was not applied directly to $W$. polycystis but related to the zoospores of Rozella, Olpidiopsis, and Horonina as a group. Cook and Nicholson ('33), on the other hand, described the zoosporc as spherical (fig. 3, 4) with two anterior flagella which lash back and forth in breast-stroke fashion in swimming. These workers were non-committal about the relative lengths of the flagella, but most of the figures slow them to be equal in length. One of their figures (fig. 3), however, shows flagella of unequal length. If the zoospores are anteriorly biflagellate, as Nicholson and Cook contended, and heterocont as Fischer reported, they do not differ fundamentally from those of the Plasmodiophorales. In view of the wide differences in observation it is not altogether improballe that what is now called $I r$. polycystis nay rclate to more than one organisn or species. Further critical studies of this species arc therefore highly essential.

So far schizogony has not been reported in $W$. polycystis, and nothing is known about the type of nuclear divisions in the regetative thallus. This parasite has never been studicd critically from fixed 
and stained material, and it is not improbible that future incestigation may reveal the ocenrence of selimogony and "promitotie" divisions. It should be noted in thiv eonnection, however, that the walls of the sporangia and resting spores of $\| F$. polycystis grive is definite erllulose reaction, while those of the Plasmodiopliorales alo not. liurthermore, in germination the content of the zoospore cuters the host througla a penetration tube (figs. is-7) leaving the emper case on the outside of the host cell as in Olpidiopsis, liozellopsis, ete. In the l'lasmodiophorales the zoospores are reported to cuter direetly. 'Tlic latter differcuec may not be important. but the presene' of collulose is fundimentally significant. according to present-day student of pliylogeny.

IIoromina glomerata parasiti\%'s species of $l$ aucheria and causes septation of the filaments without hypertroplyy (l). 2., fig. I). It forms sporangio- and cystosori, but the resting spores aml sporangia are not eluncly aggreated and compact as in $W^{\text {r }}$. polycystis hut mav lit loose and free of each other (figs. 6, 10, 13). Motile zoospores were observerl by Tokunaga who deserilued them as hiflagellate. lut notling further is known about the number, position and relative lengtl of the Hagella. 'The zoospores apparently enter the host directly and divide, according to Zopf ('9., p. .5). "J'he daughter cells soon become amocboid and after a while may divide also (fig. 2 ). The amoebre feed directly on the host protoplasm and engulf starch grains, eloloroplyyll gramules, ete., wherely they may hecome quite green in eolor. 'This engulfed food is held in sharply-defined vacuoles (fig. *), according to Selierffel. and later as the cleavage segments of the plasmodium are transformed into zoosporangia or resting spores the extraneous waste material is extruded to the outside (fig. j) like in typical proteomyxean species. As a consequence. the groups of sporangia and spores are usually accompanied hy masses of dark brown waste material (firs. 1.5, 6. in).

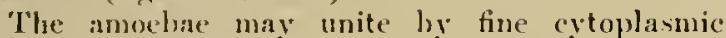
strands or pseudopords and form il reticulate plasmodium which often completely fills the delimited portions of the host filament. "The amochae may scparate again. whicl suggests that they do not lose their entity as cells in the large plasmodium but instead remain distinct and form a psendoplasmodium sugerestive of that in the Acrasicas. This, however, remains to be slown. Zojuf nevertluless reported that the large plasmodium cleaves into segments or "Theilplasmodien" at maturity.e each of whel forms a group of zoosporangia or resting spores. 'This division of amoclue and plasmodia is somewlat suggestive of schizogomy in the l'lasmodiopluoriles.

'The resting spores. unlike thouc of $\boldsymbol{H}^{\circ}$. polycystis and the plasmoliophorales, function as zoosporangia in germination and produce muncrous zoospores. The content of the spore undergoe's cleavige (figs. 11, ]2) into \%ospoure initials. While the endospore expands out througl the germ pore and forms a globular vesicle which then develops a celindrical exit tube of variable lengtl (fig. 13.1). Orcisionally, vesicles of two adjacent spores fusc and form a fommmon one (figs. 133 3, ('). After the resicle and exit tubc lave licen formed, the zoospores in the resting spore bass through these structures to the outsiale of the host. 'The ligaline resiele in this sperese is sumewhat similar in appearanee to the thin-walled, lyyline zoosporangia which are developecl on the surfice of germinating resting spores of many eleytrid specic's, but whetloce they are to he regarded as such or as inflated bisc's of exit tubes is not eertain.

As noted alove. Zopl and Schertfel regarded $\mathbb{I}^{\circ}$. glomerata as an organism witl a fungus-like life cyele and an animal type of nutrition, and they acecordingly believed that it should be placed in the family Gymmococeaceas among the Proteomyxa.

W. POLYCYSTIS Cormu, 1.4., pl. 7, figs. 1-19.

1\%. polyeystis var. sminriformis. Petersen, 1910. Ann. Mycul. $8.3,3 \%$.

Sporangosori oval, ellipsoid, somewliat irregular or elongate, $30 \times 100 \mu .60 \times 476^{\circ} \mu$ often in linear rows, lying in successively delimited septate segments of the lost hyplace. Zoosporangia oceasionally single, usually in small or large groups, lyyline, smooth, spherical, ]2-20 $\mu$, oval, ellipsoid or polyconal with a short exit tube, or papilla. Zoospores hyaline with one small granule or glolule, elongate, $2 \times+\mu$ or spherical 3.5- $\$ \mu$. Cystosori spherieal, ellipsoid, larrel-shaped. cylindrieal or jrregular, $12-\operatorname{t~} 10 \mu, 50 \times 308 \mu$. dark hrown. covered on the surface witl numerous cone-shaped and pointed projections which relate to the outer cysts or spores. Individual cysts or resting spores thick-walled, spluerical or polygonal, $4-8.6 \mu$ in diancter, usually compactly united; producing one (?) zoospore in germination.

Parasitic in the regetative filaments, zoosporangia, zoospores, antheridia and oogonia of Saprolegnia monoica and S. thureti in Germany (Fischer, 82; Minden, '11) ; Achlya polyandra, i. racemosa, Ichlya sp., Saprolegnia spiralis and Saprolegnia monoica in France (Cornu, l.e.; 1)angeard, "!o); . Sehlya racemosa in Russia (Sorokin, '83, '8!:) Saprolegria sp., in Switzerland (Maurizio, '9.5); Saprolegnia forax, Saprolegnia sp'. Achlya de Baryana, dchlya sp.., in England (Hartog. '90; Smith and Ramshottou, 17 : Cook and Nicholson, '33: Siparrow. '36) ; Saprolegnia sp.., and dchlya sp., in l)enmark (Petersen, '09, '10), and Ichlya sp)., in Sirw York, U. S. A. (Sparrow. '32. '33). ('ausing septation and marked hypertroply of the infected filaments.

Until recently most workers regarded the parasite which Pringshem ('60) described in Achlya divica as $H^{\circ}$. polycystis, lunt Couch ('39) lias shown that it relates to anotler speceies, Pringsheimm lla divica, with posteriorly unifliercllate zoospores. Cook (32) reported that $\boldsymbol{W}^{*}$. polycystis parasitizes ()edogonium crassusculum var. idiesporium in lingland. 'Illis is the only aceount so far of its oceurrence: in lusts otlier than the water molds. The plasmodia 
and sporangiosori of Cook's fungus may possibly belong to either $\Pi$. glomerata or $\boldsymbol{W}^{*}$. aggregata, or a new species. According to Fischer ("92) $\mathrm{W}$. polycystis is limited to species of Saprolegnia and will not infect Achlya, but subsequent workers have not confirmed his olservations. So far no intensive cross inoculation experiments have been made. The validity of Peterson's forma scalariformis is open to serious question.

As noted elsewhere, Fischer, Zopf, Cook and Nicholson described the mature vegetative thallus as a plasmodium, hut they did not prove conclusively whether it arises from a single infection or by fusion of several amoebae within the host cell. Minden believed that in cases of multiple infection fusion of scveral protoplasts is not an improbahle occurrence. According to Fischer the thallus may exhibit many of the characteristics of a plasmodium, undergoing amoeboid changes in shaje which are accompanied by slow and weak wave-likc streaming of its dense protoplasm. As to its mode of feeding, Zopf maintained that it engulfs the protoplasm of its host directly. Cook and Nicholson reported that it feeds on glycogen and the oil globules of its host, because they were able to demonstrate by microchemical tests the presence of the same substances in both the host and parasite. They, furthermore, maintained that the mature plasmodium or young sorus becomes surrounded by a cellulose wall as it segments into sporangia and spore rudiments; yet none of their figures show the presence of such a wall.

W. GLOMERATA (Cornu) Fischer, 1892. Rabenlorst's Kryptog. FI. I, $4: 64$.

Chytridinm glomeratum Cormu, l.e., p. 187, pl. 7, figs. $20-22$.

Zoosporangia occasionally single, more often in small groups or loose aggregates which measure $50-96 \mu \times 70-300 \mu$; individual zoosporangia hyaline, smooth, oval or spherical, 10-33 $\mu$, with a single broad flask-shaped exit tube which may or may not project beyond the surface of the host. Zoospores liyaline, oval, $2-2.6 \mu$, somewhat kidney-slıaped or ellipsoid, $2.4 \times 3.6 \mu$, with numerous small granules; position and relative lengths of flagella unknown. Resting spores in groups like the zoosporangia, hyaline, spherical or ellipsoid, 12-2.4 $\mu$, with a granulir content, thin endospore, and thick exospore which has a net-like sculptured surface similar to that of 'Tilletia tritici; functioning as a zoosporangium in germinating and producing numerous zoospores.

Parasitic in V'aucheria sessilis, $I$. terrestris and Iraucheria sp.. in France (Cornu, l.c.), Germany (Zopf, '9.4), Hungary (Scherffel, '25), Bulgaria (Valkanov, '31) and Japan (Tokunaga, '33), causing septation but no lypertrophy of the infected lost filaments.

W. AGgREgata Zopri, 1894. Physiol. Morpl. Nied. Organismen 4:60.

Zoosporangia, 10 to 20 in number, grouped in round grape-like clusters or sori, hyaline, smooth and spherical with a tubular cylindrical exit tube. Zoospores and resting spores unknown.

Parasitic in Mougeotia sp., in Germany.

This species has the same type of development as W. glomerata, according to Zopf, but differs primarily by the arrangement of the zoosporangia in the sorus and the presence of non-inflated cxit tubes. Zopf also observed a similar Horonina-like organism in the mycclium of I'ilobolus, but he did not identify it.

\section{DOUB'TFLL SPECIES}

W. ELEGANS (Perroncito) Fischer, 1.c., p. 66.

Chytriclium eleyans Perroncito, 1888. Centrallul. Bakt. Parasitk. 4: 29.5.

Sporangesori single, spherical to star-shaped, $6-110 \mu$, rosy red in color and made up of $8-20$ sporangia. Zoosporangia smooth, spherical, 20-30 $\mu$, egg-shaped or pyriform with several $+5 \mu \times$ $5-100 \mu$ cylindrical exit tuhes which bore through the cuticle of the host. Zoospores oval, somewhat elongated, $2-4 \mu \times+-5 \mu$, with two long flagella and numerous minute red granules; position and relative lengths of flagella unknown. Cystosori and resting spores unknown.

Parasitic in P'hilodina rosetta in Italy.

\section{Plate 2}

\section{Woronina glomerata}

Fig. 1. Septate filament of Jancheria terrestris with six cystosori. Zopf, "94.

Fig. 2. Septate portion of a $T$. sessilis filament with numerous amoebac, some united by fine protoplasmic strands and containing chlorophyll granules. Zopf, l.c.

Fig. 3. Same, five hours later. Amvebae have separated, begun to retract their jeseudopods, and are rounding up. Extraneous chlorophyll granules have been extruded. Zoprf, l.c.

Fig. 4. Two amoebae with extraneous material in food vacuoles, Scherffel, 25.

Fig. 5. Sporangiosorus of four sporangia, one of which has emitted its \%oospores. Extruded waste naterial lying nearby. Scherffel, l.c.

Fig. 6. Large sporangiosorus. Zopf, l.c.

Fig. 7. Two large sporangiosori. 'Tokunaga, '33.

Fig. 8. Single sporangium undergoing cleavage. Zopf, l.c.

Fig. 9. Zoospores emerging from zoosporangia. Note inflated exit tubes. Zopf, l.c.

Fig. 10. Cystosorus of loosely united and separate resting spores. Zope, l.e.

Fig. 11. Enlarged view of resting spore with sculptured exospore. Zopf, l.c.

Fig. 19. Early germination stage. \%opf, l.c.

Fig. 13. Group of germinated resting spores with long exit tubes. In two of the pairs the superficial zoosporangia or endospores have fused to form a common vesicle. Kopf, I.c.

Fig. 14. Resting spore of $\mathrm{H}^{*}$. asterina. 'Tokunaga, l.c. 
I'IA'TE 2
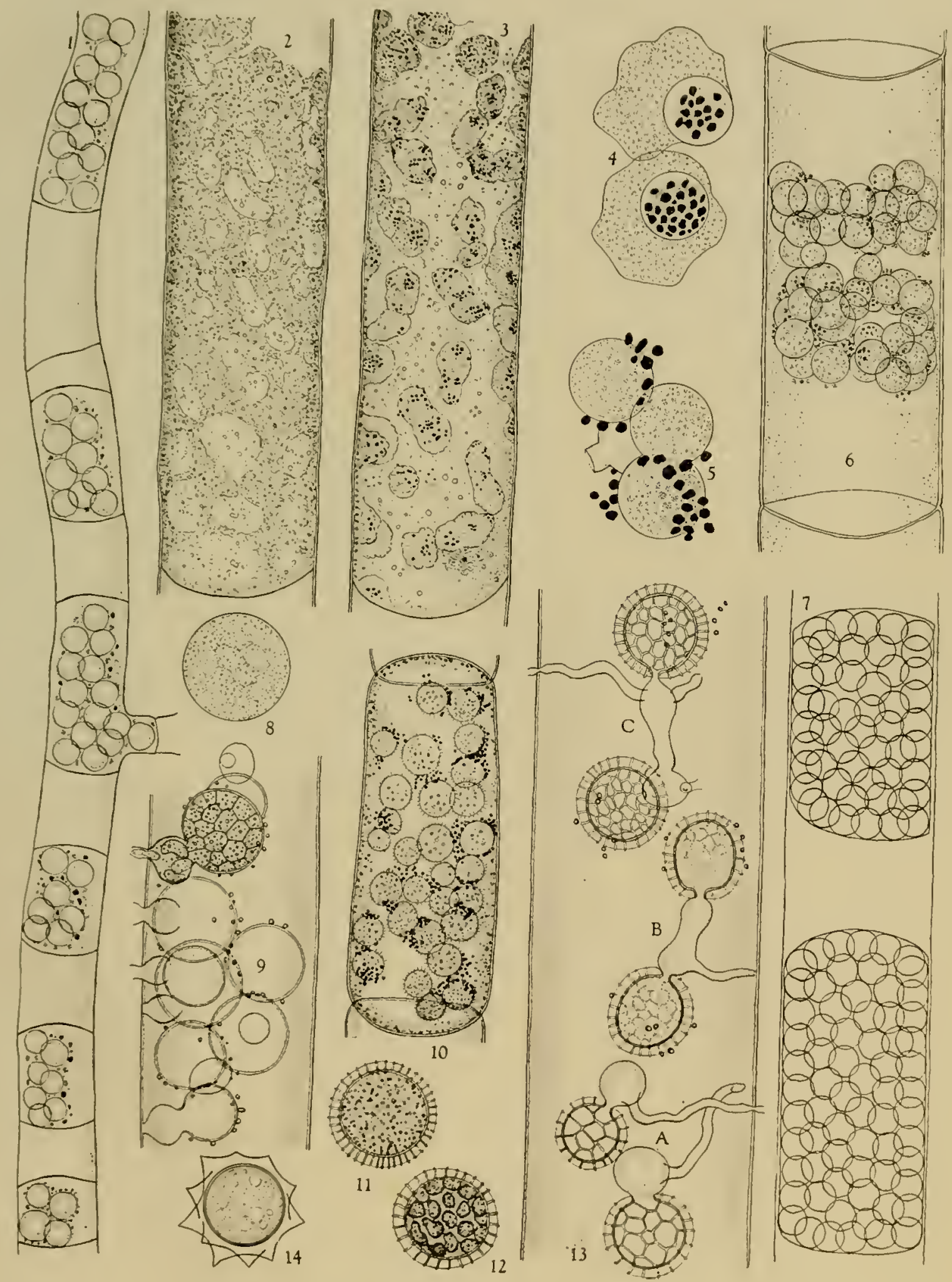

IIoronina 
This speeies is at present a doubtful member of the genus, since the cystosori and resting spores are unknown. It differs from the other species by the presence of thick greatly elongate exit tubes on the zoosporangia.

W. ASTERINA Tokunaga, 1933. Trans. Saporo Nit. Hist. Soc. $13: 26$. l'l. 2 , figs. $15,16$.

Zoosporangia 1 to 20 in number, arranged in single or doulle rows in delimited segments of lost hyphae which measure $18-30 \times 96-216 \mu$; individual zoosporangia, hyaline, smooth. spherical, $12-19 \mu$, opening by a small papilla. Zoospores lyaline, spherical or ovoid, $3-4 \mu$; position and relative lengths of flagella unknown. Resting spores loosely aggregated in single or double rows, or lying free; hyaline, spluerieal, $12-22 \mu$, witl large, broadly conical or prramidal spines; germination unknown.

Parasitic in Achlya americana in Jajan, causing septation by no hypertrophy of the host hyphae.

The validity of this species as a member of 1 roronina is highly questionable and the present writer is inclined to exelude it. The resting spores and sporangia are only loosely aggregated and often lie free in the segments of the host hyphae, and they may have arisen from separate individual thalli as in species of Olpidiopsis. Furthermore, the resting spores (fig. 11), are strikingly similar in structure and appearance to those of $O$. fusiformis $(O$. minor.). Unlike species of Olpidiopsis, howerer, $W$. asterina does not cause hypertrophy of the host hyphae, but whether or not this character is specifie remains to be seen.

\section{PYRRHOSORUS}

Juel, 1901. Bih. Kgr. Srensk. Vet.-Akad. Hand. 26, afd. III, No. 1t: 1 t.

(P1.ATE 3)

Thallus intramatrical, plasmodial. naked when young but apparently immiscible with the lost protoplasm; becoming invested with a wall at maturity and segnenting into spore-mother cells which aggregate to form a sorus. Spore-mother cells dividing three times to form octads of naked spores which soon become transformed into laterally biflagellate, isocont zoospores. Zoosporangia and resting spores lacking (?) or unknowu.

This genus was created for an orange-colored fungus which Juel found parasitizing a red alga. Cystocloninm purpurascens, in Sweden. As has been pointed out by the writer ('42) in his book on the Plasmodiophorales, it has many characteristics in common with these organisms, hut differs by its laterally biflagellate isocont zoospores, naked sporemother cells and spores; lack of zoosporangia and resting spores; and by its saprophytic habit of life. As is shown in figure 1 its zoospores are strikingly similar to those of many of the simple holoearpic biflagellate isocont Oomycete-like fungi, and offhand it might be regarded as a transition form between this group and the Plasmodiophorales. However, to interpret it as such does not seem fully warranted at present, since the complete life cycle of $P$. marinus apparently is not known. For the time being, Pyrrhosorus is included in the Woroninaceae as this family is herewith interpreted.

\section{P. MARINUS Juel, l.c., p. 14, figs. 1-99.}

Plasmodium or thallus partly or completely filling host cell and extending into adjacent cells. Sporemother cells spherical, $8 \mu$, with numerous refringent orange globules. Zoospores pyriform, 2.5 $X$ $4.5 \mu$, with an orange pigment sjot; flagella oppositely direeted in swimming.

Saprophytic in dead branches of Cystoclonium purpurascens in Sweden.

The life cycle of $P$. marinus is as follows: In the early developmental stages it consists of small globular thallus lying within the host cell (fig. 2). Such thalli may often be associated in pairs (fig. 3) or groups, and $J$ uel accordingly considered it possible that they may later coalesce and form a large plasmodium. The uninucleate thallus grows in size as its nueleus enlarges (fig. 4) and apparently divides. Mitoses in the plasmodium have not been observed, and $J$ uel was uncertain as to the manner of origin of the multinucleate stages. A later stage is shown in figure 5 of a plasmodium with four large nuelei. The developing plasmodia apparently have the ability to dissolve intervening cell walls (fig. 5) and may eventually occupy several cells. Although they may be distinctly amoeboid in shape with numerous blunt

PLATE 3

Pyrrhosorus marimus

(All figures after Juel)

Fig. 1. 1.aterally biflagellate isocont zoospores with an orange colored eye spot.

Fig. 2. Tninucleate thallus.

Fig. 3. Paired young thalli.

Fig. 4. Uninucleate thallus with enlarged primary meleus.

Fig. 5. Four-nucleate thallus passing througl cell wall.

Fig. 6. Multinucleate thallus.

Fig. 7. Multinucleate anocboid thallus.

Fig. 8. Cleavage into spore-mother cells.

Fig. 9. Sorus of spore-motluer cells.

lig. 10. 1solated spore-mother ceill.

Fig. t1. A sorus, the spore-mother cells of which have divided into groups of four daughter cells.

Fig. 12. Spindle-shaped spore-nother cells (?) in a brancled thallus.

Fig. 13. Spindle-sliaped spore-mother cells and accessory sterile cells in an elongate host cell.

Fig. 1.4. Sorus with spore-mother and steril. cells.

Fig. 15. Nuelei of sport-mother eells dividing.

Fig. 16 to 19. Mitosis and cytokinesis of spore-mother cells. 
PIATE:3
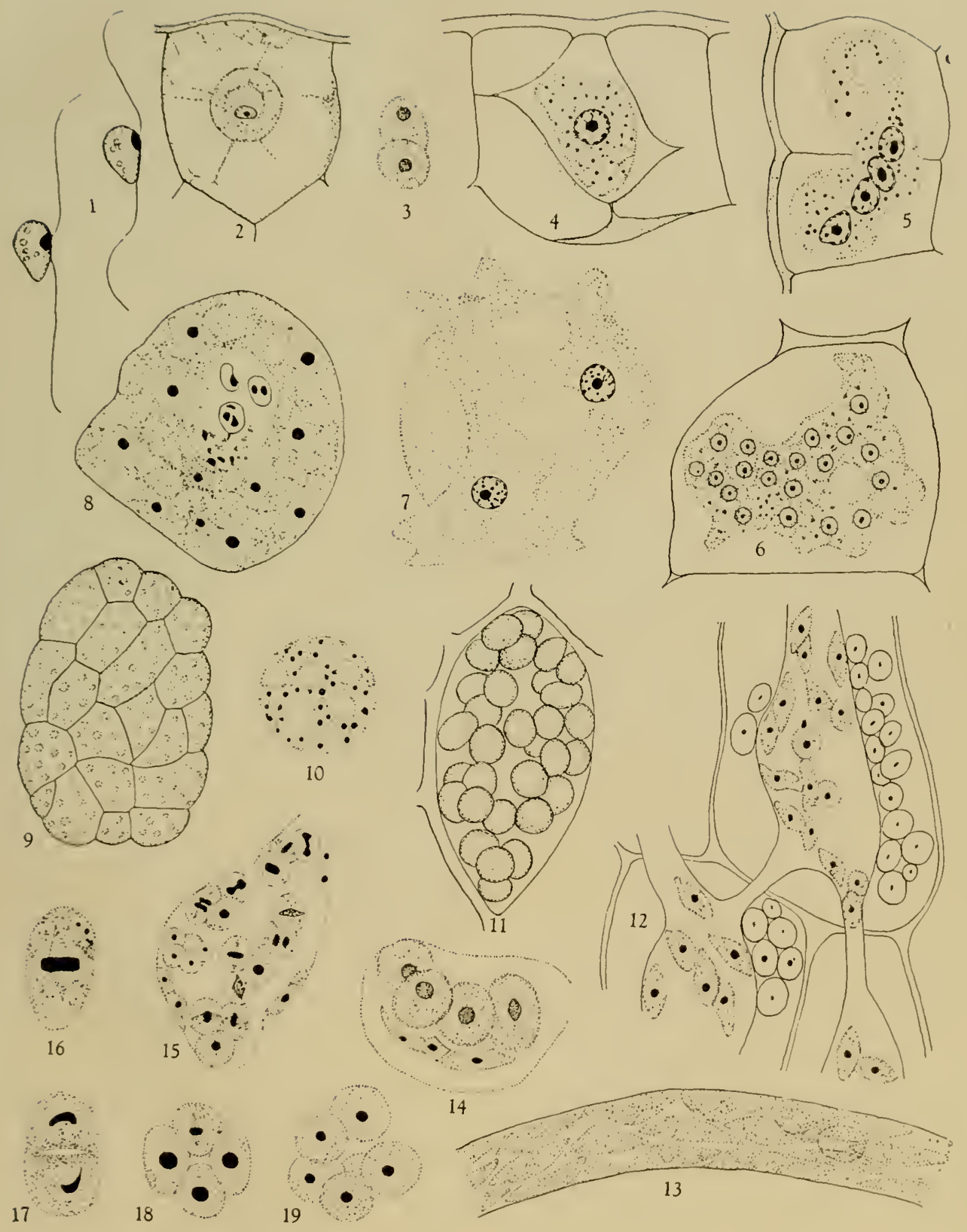

Pyrthosorus 
pseudopod-like extensions and racuoles (figs. 6, 7) it is not certain from Juel's account that they move about and migrate from cell to cell as in Plasmodiophora, etc. No evidence of schizogony was observed by Juel, but Winge interpreted some of the uninucleate stages as prohable meronts.

The mature plasmodium is multinucleate, vacuolate, and usually irregular in shape (figs, 6-8), and just before sporulating forms an enreloping membrane like Sorolpidium. Plasmodia which are extensively drawn ont and occupy several host cells may accordingly appear lobed, irregular, and tubular (fig. 12) after the wall has formed. Following this stage the protoplasm divides into minucleate segments. In this process no distinct cleavage furrows have been observed. The plasmodium appears to become highly vacuolate (fig. 8 ) during this process. and the cytoplasm accumulates around the nuclei and forms stellate protoplasmic islands which resemble somewhat the sporonts of Tetramyxa. These segments soon become almost splierical or spindleshaped (fig. 12), and $J$ uel thought that the latter type of cells are formed in plasmodia which are lighly vacuolate and scarce in cytoplasm. In addition to these two kinds of segments, irregular elongate, oval and smaller ones may be formed, apparently as the result of unequal cleavage, which finally degenerate.

The spherical, $8 \mu$ in diameter, and spindleshaped segments are minucleate, naked, and never develop a distinct wall. They aggregate to form a definite sorus (fig. 9) and each cell soon divides into octads of spores as in Octomyxa, which led Juel to call them spore-mother cells. In this process of spore formation the nuclei divide mitotically (figs. 15-18) and each mitosis is followed hy cell division. Definite chromosomes ( 2 to 5 ) are formed on a sharplydefined spindle during mitosis, and there is no evidence of "promitosis," according to Juel's figures. Each of the eight naked spores soon becomes transformed directly into zoospores without developing thick walls and becoming dormant. The zoospores apparently infect the host cells and develop into the small thalli shown in figures 2 and 3.

\section{ROZELLOPSIS}

Karling, 1942. Amer. Jour. Bot. 29: 33. Mycologia $3 t: 205$.

(PLATE 4)

Thallus, intramatrical, more or less indistinguishable from but apparently immiscible with the host protoplasm; becoming invested with a wall at maturity and forming one sporangium; or cleaving (?) into several segments which become separated by host walls, mature in basipetal succession, and develop into sporangia or resting spores. Sporangia terminal or intercalary in host lyphae, variable in size and shape, with one to several exit papillae which extend through the host wall; usually filling the host sporangia or the hypertrophied portions of the hyphae completely; sporangium wall tightly pressed against, seemingly fused with, and usually indistinguishable from that of the host. Zoospores slightly variable in size and shape, with one to several minute globules, heterocont, shorter flagellum usually extending forward and the longer one hackward in swinming; zoospores swirling in the sporangium before emerging and swimming away; content of zoospore flowing into host cell through an infection tube in germination, leaving the empty zoospore case attached to host cell. Resting spores unknown in monosporangiate species; solitary in septigenous polysporangiate species, lying free within host cell and separate from host wall, variable in size, brown and spiny; protoplasm coarsely grannlar, including a large vacuole or globule of hỵaline material; germination unknown.

This genus was created for the Rozella-like species witl biflagellate heterocont zoospores which have been described from time to time. As such it is perhaps scarcely more than a provisional dumping ground for imperfectly known species of this type. It was proposed primarily to include Pleolpidium inflatum Butler ('07) and a similar parasite which Miss Waterhouse ('40) found in Phytophthora. Whether or not the species which Fischer described as $R$. septigena and $R$. simulans belong here is obviously open to question. He figured and described the zoospores as biflagellate and heterocont, but it is particularly noted in this connection that his description does not apply specifically to these species. It relates instead to the zoospores of Woronina, Olpidiopsis and Rozella collectively. Inasmuch as many of Fischer's observations of other similar parasites have proven inaccurate. it is not altogether improbable that he may have been mistaken about the number, relative lengths, and position of the flagella. On the other hand, it is equally probable that he had at hand a different fungus from the one described by Cornu as $R$. septigena. This is suggested by $\mathrm{To}$ kunaga's ('33) confirmation of Fischer's report of biflagellate heterocont zoospores in $R$. simulans, which is identical to $R$. septigena except in host range. For this reason Fischer's $R$. septigena has been separated from Cornn's species of the same name and placed temporarily with $R$. simulans in Rozellopsis. This genus accordingly includes two incompletely known aseptigenous monosporangiate, and two doubtful septigenous, polysporangiate species.

So far as is now known Rozellopsis has the same type of derelopment as Rozella. In monosporangiate species the thallus develops into one sporangium or resting spore, whereas in the septigenous nembers the thallus is reported to segment into several portions, each of which develops into a sporangium or a spore. Germination of the zoospores, infection, and entrance of the parasite have not been observed in $R$. inflata, so that the following description of the processes is based on $R$. waterhouseii and $R$. septi- 
gena. Aecording to lischer and Miss Waterhouse the zoospores come to rest on the host hyphac ind dovelop germ tuhes of variable lengths (figs. 5-7. 11i) which prenctrate the host wall. 'The contents flow into the fungus hyphat through this tuhe and soon become obseured by and almost completely lost to wight in the lost protoplasm. Although it is not visible as a clearly-defined hody its presence is nevertheless coident by the incrensed density and opraty of the host protoplasm in the region of infection. Fincher reported that the young thallus of $R$. septigena loses all individuality as it mixes with the lost protoplasm and develops into a plasmodium, but his aceount is not based on observitions of fixed and stained material. It is not improhalile that the parasite remains naked until very late in development, hut it is apparently immiscible with the host protoplasm. If it is amolooid in sluape with numerous fine pseulopods it may well infiltrate the interstices of the host protoplasin and appear to be fused or mixed with the latter. 'This, however, remains to be determined by intensive extological study of fixed and stained material.

As the parasite increases in size and attains regetative maturity, mumerous small vacuoles usually appear in the cytoplasm of the hypertroplied portions of the host hyphae (figs. 9, 16), but it is not always certain whether these vacuoles relate to the cytoplasm of the parasite or the host. However, since they scem to fuse later and form the large central vacuole of the parasite's sporangium (fig. 10) they probably relate to the parasite. Such vacuoles may nove ahout and undergo marked changes in shape from time to time (fig. 9). According to Butler, the vincuolate stage is not very narked in $R$. inflata. At this stage one or more dome-shaped exit papillae are usually present which project through the lrost wall (figs. 9, 10). Their presence is probaly a indication that the parasite has reached vegetative maturity and been transformed into an incipicnt sporangium. The formation of the sporangim wall has never heen obscrved, but it las been descrihed in the literature as indistinguishable from and secmingly fused with that of the host. However, by plasmolytie experiments Miss Waterlouse demonstrated that $R$. zaterhouseii has a distinet membrane of its own which may be readily stparated from the host wall. Whether or not it is componed largely of cellulose had not been determined.

Cytokinesis is probably accomplished by centrifugal cleavage furrows which progress from the border of the contral vacuole to the peripliery, although it has not yet heen clearly demonstrated. According to Wiss Waterhouse, the visilule elanges in the protoplasm preparatory to sporogenesis are quite characteristic. 'Tle central vacuole may disappear, leaving the protoplasm quite clear and homogeneous except for a few dark gramule's in the ecnter. Shortly thereafter the protoplasm takes on the appearance as if it had undergone cleariag into zoosjore initials, but this phase persists only for a short time. The protoplasm lecomes optioally alear again, and after i period of about half an hour the exit papillac deliquesce and disapluar (ompletely, leaving a rytuplasmic membrane aeross the orifice. Following this stakge tlic protoplasm becomes fincly reticulate in alppearanee. and shortly thereafter the definitive spore initials are formed (tig. 11). As these become more elcarly defincel the whole mass of segments berins to glide and move around. This movement imereast's in intensity urtil the zoos]ores are swarming and swirling around in the sporangium. Within al'ow minutes the membrane across the orifice bursts and the zoospores are discharged in a dense eloud-like mass.

All species of Rozellopsis are reported to have heterocont zoospores with the shorter flagellum extending forward in swimming (figs. 4, 13, 15). The exact point of insertion of the flagella is not certain in $R$. zeaterhouse $i$, but in $R$. in flata and $R$. septigena Fischer and l3utler reported that the short flagellum arises from the anterior end (fig. 15) while the longer one is laterally inserted. In $R$. simulans, on the other hand, hoth flagella arise from the anterior end (fig. 23) as in the Plasmodiophorales, according to Tokunaga. In swimming the zoospores move along more evenly and smoothly in a straight or curved path in marked contrast to the jerky darting motion of the zoospores of Rosella species. They may also round up and eneyst (fig. 1.4), hut so far no evidence of diplanetism has been observed.

The development of septigenous species is similar to that deserihed ahove for aseptigenous members, with the execption that the thallus produces more thin one sporangium or resting spore. Fischer deseribed the thallus in $R$. septigena amd $R$. simulans as a plasmodiun which fragments or undergoes schizogony into several segments. Althougl he frequently noted instances of multiple infection (fig. 16) Fischer nonctheless believed that each plasmodium is the product of a single infection. As evidence thint the thallus fragments, he reported cases of single spores giving rise to $5,2,4$, and 7 sporangia, In cases of multiple infection the resultint thilli or plasmodia remain scparate and do not fuse, aucording to Fiscluer. As noted elsewhere his studies do not relate to experimentally controlled monospore infections, and until such studies have hecn made the problem of whether or not a single infection eventually gives rise to several sporangia or resting spores remains to be conclusively settled. However formed, the thallus or plasmodium is reported to frament and the portions becone separated hy transierse host walls and mature in hasipetal snceession (figs. $17,2.2)$.

The process of resting spore formation in the septigenous species appears to be the same as that of Rozella, although it must be noted in this commection that Fischer's figures (figs. 18-21) may possib) relate to Rozella instead of hozellopsis. Assuning that the stage's shown in figures 18 to 21 helong to the parasite with biflagellate het:rocont zoospores (fig. 1.5), it is evident that the proecss is strikingly 
sinilar to that of Rozella. The portions of the thallus or "plasmodium" in the liypertrophied hyphal segments or swollen side branches ajpear to eontract and locome invested with a wall (fig. 19), so that they lie loose and free in the host cell. The incipient spores usually lie in a clear space which in turn is surrounded by a layer of host cytoplasm (fig. 20) from which strands radiate to the periphery. The clear area is apparently the region in whieh the host eytoplasm is transformed into spore wall material. hecause as the cytoplasm decreases in amount definite spines are deposited on the outer wall of the spore (figs. 20, 21). The spines and echinulations seem thus to be nothing more than modified host protoplasm as Butler (07) and $\mathbf{M c}$ Larty ('t1) have shown in Olpidiopsis Pylhii and $O$. Achlyae. Germination of the resting spores has not been olsserved, but they probably give rise directly to zoospores as in Rozella.

As is shown in plate $t$, Rozellopsis produces a marked reaction in the host hyphae which involves both cell enlargement and cell division. Hypertrophy is local and confined largely to the region of infection. According to Miss Waterhouse's figures (figs. 5-7) it may even begin during infection. Eventually the infected portions of the liyphae may hecome ten to fifteen tincs their normal diameter (figs. 1-3) and are usually delimited from the remainder of the mycelium by cross walls (figs. 9-12, $16,17,22)$. Such cross septa may become unusually thick (figs. 11, 12) and in extreme cases project up or down into the hypertrophied portions as domeshaped plugs. In the cases of infection by septigenous species the fragments of the "plasmodium" are successirely delimited by walls, so that an infected lyphal tip may have a large number of cross septa (figs. 17, 22). The reaction of the host nuclei and cytoplasm to the presence of the parasite is not known, since most studics to datc have been made on living material. However, as noted preriously, lischer believed that the two protoplasts mix and hecome indistinguishable, but this seems unlikely.

The taxoumic position and relationship of Rozellopsis to the simple holocarpic biflagellate fungi are very uncertiain at present, and solution of these questions must await furtler study. In view of the reports that its thallus is a plasmodium which undergoes schizogony in the septigenous species, Rozellopsis is herewith included provisionally in the famjly Woroninaceae in the restricted sense noted ahore. This disposition is olviously temporary and may he completely invalidated by future studies. The jirescnce of a plasmodium which may undergo fragmentation still remains to he demonstrated in Rozellopsis, in the writer's opinion. If schizogony does oceur in the septigenous members it may hecome necessary to segregate them in a seprarate genus. The prescnce of anteriorly hiflagellate heterocont zoospores in $\boldsymbol{l}$. simulans suggests direct aftinity with the Plasmodiophorales, hut this relationship likewise remains to be proven.

\section{Aseptigenous Monosporangiate Species}

R. INFLATA (Butler) Farling, 194:. Ameı. Jour. Bot. $2 !): 34$.

Pleolpidium inflatum Butler, 1907. Men. Dept. Agric. India. I3ot. ser. 1: 126, 1:\%, pl. $\tau$, figs. 1i-21.

Sporangia terminal, spherieal, up, to $85 \mu$ in diameter, oval, or pyriform $w$ ith one to several exit papillae. Zoospores reniform, kidney-shaped with the shorter flagellum attached at the anterior end and the longer one at the side; swimming smoothly in long curves. Resting spores unknown.

Parasitic in Phytium intermedium, An $\mathrm{t} i \mathrm{bes}$, France, causing marked hypertrojhy of the host sporangia.

\section{R. WATERHOUSEII Karling, l.c., 1. 34.}

Sporangia terminal, spherical, up to $74 \mu$ in diameter, clavate, oval, or obpyriform with $1-3$ apical or lateral exit papillae. Zoospores pyriform, 5-8 $\mu$

\section{PLATE H}

$$
\text { Rozellopsis influta }
$$

(Figs. 1-4 after Butler, '07; figs. 5-14 after Miss Waterhouse, ' 40 ; figs. 15- 21 after Fischer, '82; figs. 22,23 after Tokunaga, '33.)

Fig. 1. Sporangia in the hyphal tips of Pythium intermedium.

Fig. 2. Zoospores within a sporangium.

Fig. 3. Empty sporangium.

Fig. 1. Heterocont zoospores with one or two refractive globules at the ends.

$$
\text { R. waterhouseii }
$$

Figs. 5-7. Infection of hyphal tip of Phytophthora cryptogi'w.

Fig. 8. Early stage of hypertrophy.

Fig. 9. Later stage. Sporangium of parasite delimited by cross sejta, multivacuolate with one exit papilla.

Fig. 10. Still later stage in which the vacuoles have fused to form a large central one.

Fig. 11. Sporangium with zoospore initials.

Fig. 12. Zoospores swarning in the sporangium and emerging through the exit orifice.

Figs. 13, 14. Heteroeont motile, and encysted zoospores.

$$
\text { R. septigrull }
$$

Fig. 15. Heterocont zoospores with one refractive globule. Shorter flagellum at anterior cond.

Fig. 16. Multiple infection of Saprolegniu hyphal tip.

Fig. 17. Hypertrophied and septate host lypha with several "Reihensporangien" in various stages of development.

Figs. 18-21. Stages in development of the resting spores.

$$
\text { R. simuluns }
$$

Fig. 22. Infected hypha of Achlya flugellute with sporangia in various stages of maturity.

Fig. 23. Anteriorly hiflaguthate heterucont zoospores with a refractive globule. 
PIATE +

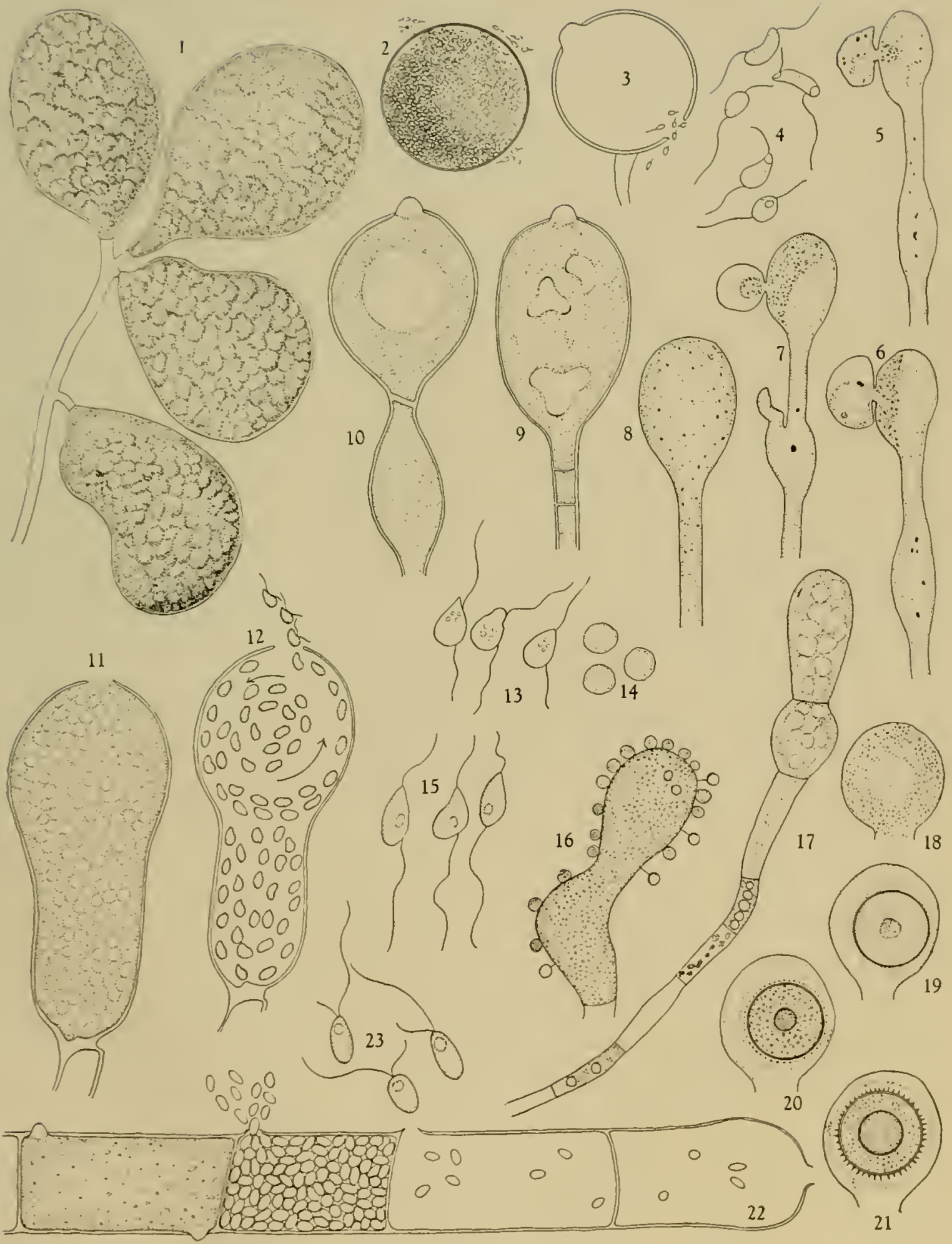

Rozellopsis 
long witl a few small refringent granules in the center or near the posterior end; flagella apparently laterally inserted (?); zoospores active for twentyfour hours or more, or rounding up and encysting. Resting spores unknown.

Parasitic in Phytophthora cryptogea and $P$. megasperma, London, England, causing occasional hypertrophy of the host sporangia and supporting hyphae.

Miss Waterhouse discovered this parasite in material collected from the Hogsmill River, a Surrey tributary of the Thames, and gave an excellent account of its development and infection of the lost. She succeded in inoculating $P$. megas perma with it, hut all attempts to infect Rhiphidium continum and $R$. americanum were unsuccessful. This species differs from $R$. inflata by its pyriform zoospores and the fact that it causes only slight hypertrophy of the host. Bccause of its similarity in other respects to Butler's species, Miss Waterhouse, however, did not diagnose it as a new species.

\section{Septigenous Polysporangiate Species}

\section{R. SEPTIGENA (Fischer) Karling, l.c., p. 34.}

Rozella septigene Fischer, 188?. Jahrb. wiss. Bot. 13:321. Pl. 14, fig. 19; pl. 15. (Not R. septigenu Cornu, 1872.)

Sporangia up to 20 in a linear row in delimited segments of the host hyphae, of the same size and shape as the hyphal segments, with 1-2 apical or lateral exit papillae. Zoospores elongately pyriform, $+\mu \times 6-8 \mu$, hyaline, with a minute central refractive spot; shorter flagellum anteriorly attached, longer flagellum lateral. Resting spores solitary in segments of the hyphae or in short swollen side branches or "false oogonia," spherical, $20 \mu$, with a hraline endospore and spiny brown exospore, spines $2 \mu$ long; contents coarsely granular, including a large refractive globule; germination unknown.

Parasitic in Saprolegnia monoica and S. thureti in Germany (Fischer, I.c.; Minden, l.c.) causing hypertropliy and septation of the host lyphae.

Fischer's attempts to inoculate Ichlya with this species failed, and he accordingly concluded that it is linited in host range to Saprolegnia. His results have not been confirmed experimentally.

R. SIMULANS (Fischer) Karling, l.e., p. 3.1.

Rozella simulans Fischer, 1.c., p. 321 ; Minden, l.c., p. 271 , fig. 11a; 'Tokunaga, 1933. Trans. Sapporo Nat. Hist. Soc. $13: 25$. 1'l. 2 , figs. 12-14.

Sporangia up to 15 in a linear row in delinited segments of the host hyphac. cylindrical, barrelshaped, $25-90 \mu \times 60-250 \mu$, with $1-2$ apical or latcral cxit papillac. Zoospores elongate, ellipsoidal,
2.4 $\mu \times 6 \mu$, lyaline, with a small refractive spot and two unequal flagella attached at the antcrior end. Resting spores solitary in short swollen side branches or "false oogonia," of the same size, sliape, content, and appearance as those of the previous species; germination unknown.

Parasitic in Achlya polyandra and 1. racemosa in Germany (Fischer, l.c.; Minden, l.c.), Achlya sp., in Switzerland (Mauricio, '95), and A. flagellata in Japan (Tokunaga. I.c.), causing hypertrophy and scptation of the host hyphae.

According to lischer, this species is similar to $R$. septigena and differs only by its limitation in lost range to species of $A c h l y a$. Suhsequent workers who reported its occurrence, however, did not make cross inoculations but accepted Fischer's observations without question. Inasmuch as Minden apparently did not detcrmine the number, relative lengths, and position of the flagella of his fungus, it is just as probable that the resting spores which he figured relate to $R$. septigena as to the present species. Likewise, it is not certain that Tokunaga's species is $R$. simulans, although the host reactions and sporangia are similar. He figured the zoospores as anteriorly biflagellate and narrow, while Fischer described them as large and cxactly similar to those of $R$. septigena with the short flagellum anteriorly and the long one laterally attached. Consideration, however, must be given to the difficulty of determining the cxact position of the flagella on active zoospores, and it is possible that these differences in observations are due to this factor. If this species is identical to $R$. septigena, as Fischer maintained, and will infect only ichlya, it may possibly he a physiological race of the former species.

\section{BIBLIOGRAPHY: WORONINACEAE}

Cook, W. R. 1. 193\%. New Phytol. 31, 133. and W. H. Nicholson. 1933. Ann. Bot. 17: 851 .

Couch, J. N. 1939. Jour. Elisha Mitchell Sci. Soc.

Dangeard, P. 1. 1890. Le Bot. 2:63.

Hartog, 11. M. 1890. Rept. 6th Meeting Brit. Assn. Adv. Sei. $1890: 872$.

Karling, J. S. 194:. The Plasmodiophorales. New York.

Maurizio, A. 1895. Jahrl. Nat. Gesc-ll. Graihundens. 38:9. McI arty, D. A. 1941. Bull. Torrey Bot. Club. 68:49, 75.

Petersen, H. E. 1909. Bot. Ark. 29 :5.

1910. Ann. Mycol. 8:494.

Pringsheim, N. 1860. Jahrb. Wiss. Bot, $2: 305$.

Scherffel, A. 1925. Arch. Protistk. 52:1.

Smith, A. I. and J. Rambbottom. 1917. 'Trans. Brit. Mycol. Soc. $6: 231$.

Sorokin. N. 1883. Arch. Bot. du Nord France. 2:1. 1889. Rev. Mycol. $11: 7.1,81$.

Sparrow, F. K. 1932. Mycologia, 24:273. 1933, Ibid., 25: 515. 1942, Ibid. 34: 113.

- 1936. Jour. Linnean Socjety. Iondon, Botany, $50: 425$.

Valkanov, A. 1931. Arch. Protistk. 73:361.

Waterhouse, G. M. 1940. Trans. Brit. Mycol. Soc. $24: 7$. 


\title{
Chupter III
}

\section{Ectrogellaceae}

\author{
Scherlfcl, 1925). Areh. Protistk. 52: 6.
}

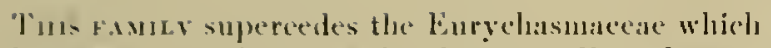
Petersen created in 190.) for the genus lineychasma. Because Petersen ineluded his family in the Myxochytridiales. with which it has little in common except for its olpidiond holocarpic thalli. Selserficel regarded the Furyehasmaceac as invalid. Although he placed Furychasma and lictrogella in the Salprolegniaceace he nevertheless sugerested (p) (i) that they might comprise a separate family, the l'cetrogejlaceac. Which le described as a group of simple silprolegniaceous fungi the thalli of which are transformed holocarpically into single zoosporangia. Coker and IIatthews ('37) incorporated sicherffel's family in the saprolegniales and atded the genus Aphanomycopsis which Scherffel had inchuded in the Silprolegniaceae. A similar interpretation was made hy sparrow in 1933 and 1936. In his recent (' $t$ '2) classification of the aquatic phyconycetes he placed the Ectrogellaceate as the first and most primitive family of the Saprolegniales and added his new genus Eurychasmidium to the groups. Acording to his classifieation, this family includes Ectrogolla, Eurychasma, Eurychasmidium, and Aphanomycopsis. Whether Aphanomycopsis lelongs here or in the Lagenidiaceae or Saprolegniaceac is open to serious question. As will becone more evident helow its thalli may he strikingly similar to those of parthenogenetic species of Iagenidium. On the other hand, it may also have the alperarance of a species of I phanomyces in which sporangia are not well differentiated.

The sugerested relationship of this family to the Saprolegniaceae is hased largely on the similarity in method of zoosjorogenesis, the presence of diplanctism. and in the structure and hehavior of the zonmores, since evidence of sexual reproduction in the Fetrogellacese is at present very meager and inconclusive. Resting spores are unknown in Enrychaswa, Eurychasmidium and in all species of Ectrogella except F. Licmophorae and li. perforans. In Iphanomycopsis they appear to be formed parthenogenetically or merely hy the contraction and eneystment of the cell content. In F. I.icmophorae fusion of undifferentiated male and feniale thilli has been reported, but the cridence presented is not conclusive.

\section{ECTROGELLA}

Zopf, 188t. Nova Acta K'sl. I cop.-Carol. Deut. Akad. Sat. $+7: 175$.

(PL.AT: j)

Thalles intramatrical. lolocarpic. wall showing a mare or less marked cellulose reaction when tested with chloro-iodide of zine; 0 al, clongate, cylindrical and rermiform: forcing the valves of the diatom lost apart at maturity. Zoosporaneria singre or numerous, liyaline. smootl, oval, egg-shaped, clongate, cylindrical. vermiform and slightly jrregular, sometimes becoming partially extramatrical at maturity, with one to several comparatively short, wide, tapering exit tubes which project between the separated valves of the diatom cell. Zoospores variable in shape, lyaline, with one to several small refractive granules: usually becoming active within the sporangium; diplanetic, primary swarmers anteriorly or laterally biffagellate and isocont. emerging singly and swimming directly away as in Saprolegnia; or aflagellate, griding out and encysting in a group at the mouth of the exit tulse as in lehlya; seconclary swarmers oval, lemon-sliaped, and pryiform, usually with a ventral furrow, laterally biflagellate with the flagella inserted nearer the anterior end; the shorter active flagellum directed forward and the longer one lackward in swimming. Resting spores lyaline. smootl, spherical or oval, thick-walled with one large or several smaller ref ractive globules; formed parthenogenetically or by the fusion (?) of the contents of a small male thallus or antheridium (?) with that of female thallus through a broad conjugration tube; germination unknown.

This genus was first included in the Olpidinceac. but since the discovery that the zoospores are biHagellate and diplanetic it has been regarded, particularly by Scherffel, Coker and Matthews, and Sparrow, as a primitive group of the saprolegniales. As it is here constituted Estrogella inchudes five species, some of which may possilly prove to be identical from future studies. All are parasites of diatons and infect marine as well as freshwater speccies.

The life history and development of Ectrogella species are shown in plate. 5. The zouspores conne to rest on the host cell and put forth a germ tule which soun penctrates the silicified wall of the host (fig. 1). The content of the sporte then flows into the host. leaving the empty zoospore casce and penetration tube behind. The young thallus is at first unimucheate, naked and anoeboid with numerous preudopods (fig. 28) but becomes conveloped ly at thin membrane or wall very shortly after entering the host cell. Mlultiple infection may frequently orour, so that as many as thirty young thalli may orcasionally he found in a single eell. As the thalli develop the chloroplasts of the host lecerin to lose their normal color, disintegrate and break down. So far me direet ('ngulfing of masses of host protoplanm or discretc bodies by the thallus has been ohserved. With in- 
crease in size and maturity the wall of the thallus becomes well defined and conspicuous, while the protoplasm takes on a greyish-granular appearance like that of the Saprolegniaceae (figs. 1-2). Numerous small vaeuoles are usually present during the early development stages (figs. 6, 7) but these gradually fuse into a large central one with an irregular outline (figs. 10,19). As a result the remainder of the protoplasm is displaced towards the periphery of the sporangium where it forms a comparatively thin, irregular, parietal layer. Simultaneous with these changes and the transformation of the thallus into a zoosporanginm the valves of the diatom cell are spread apart (fig. 18), and the exit tuhes hegin the push out. These vary greatly in number, diameter, and length, and in E. Licmophorae hecome thick-walled and inflated at the base, whereby they are able to sejarate the valves of the diaton. As a result of this spreading apart of the diatom shell and the growth of the exit tules, the zoosporangium may hecome partially extramatrical, and in E. perforans and E. Licmophorae especially, it has much the same appearance and relation to the lost as that of Eurychasma.

The exit tubes and adjacent portions of the mature sporangium wall give a marked cellulose reaetion when treated with chloro-iodide of zinc, while the remainder of the wall reaets only slightly or not at all. Petersen (05) interpreted this differenee as a matter of age and activity. Scherffel found that the empty zoospore cysts likewise give a marked cellulose reaction.

Cleavage and zoosporongenesis occur in the same manner as in the Saprolegniaceae according to Scherffel. Furrows progress centrifugally from the border of the central vacuole (figs. 10, 19, 22) and thus delimit the zoospore initials. As these furrows progress numcrous small refractive globules may appear at the inner periphery of the zoospore rudiments (fig. 23). When the cleavage furrows have rcached and cut through the plasma membrane, the central vacuole disappears, and the whole sporangium takes on a coarsely granular appearance and the zoospore initials are no longer visible (fig. 11). This is known as the homogeneous gramular stage of zoosporongenesis. It is doubtless the result of a rehydration and swelling of the zoospore anlagen, as Harper ('99) described for Synchytrium, wherehy the lines of demarkation become very faint or invisible. After some time the outlines of the zoospores become visible again (fig. 14), and shortly thereafter they begin to shakc, wobble, and glide upon each other. These are the so-called primary swarmers which are oval to pyriform in shape and may be aflagellate or liave two equal rudimentary flagella attached laterally (fig. 13), or at the anterior end (figs. 26, 30, 31). These primary swarmers may emerge and swim directly away as in Saprolegnia, or glide out and encrst at the mouth of the exit tubes as in Achlya (figs. 14, 27, 32).

Scherffel regarded the method of cleavage and zoosporongenesis described above as typical of the
Saprolegniaceae and not of the Chytridiales, and for this and other reasons he maintained that Ectrogella is a member of the former family. As the present writer has pointed out previously (' 37 ) cleavage in this genus is not fundamentally different from that described by Harper ('99, '14), Swingle ('03), Schwarze ('22) and others for the Mycetozoa, Chytridiales, Ooonycetes and Zygomycetes in general. The point which Scherffel tried to emphasize is not

\section{PLATE 5}

\section{Eetrogella bacillariacearum}

(Figs. 2-5, 17, 18 after Zopf, "84; fig. 35 after Petersen, '09; remainder after Seherffel, '25.)

Fig. 1. Early infection of Syuedra cell.

Fig. 2. Synedra cell with 21 small parasites.

Fig. 3. Synedra cell with one elongate tubular parasite.

Fig. 4. Surface view of infected Synedra cell.

Fig. 5. Mature sporangium witl central vacuoles.

Figs. 6-9. Stages of growth and maturation of sporangium. Small vacuoles fusing to form central row of larger vacuoles.

Fig. 10. Centrifugal cleavage.

Fig. 11. Contracted granular stage following cleavage.

Fig. 12. Reaplearance of outlines of cleavage segments.

Fig. 13. Primary zoospores with rudimentary flagella.

Fig. 14. Syuedre cell with encysted Ectrogella zoospores at mouth of exit papillae.

Fig. 15. Empty cysts and secondary zoospores.

Fig. 16. Laterally biflagellate heterocont secondary zoospores.

Figs. 17, 18. Empty zoosporangia with several exit papillae.

\section{E. monostoma}

Fig. 19. Mature zoosporangia undergoing clearage; exit papilla at $A$.

Fig. 20. Empty cysts and eystospores at mouth of exit papilla.

Fig. 21. Laterally biflagellate heterocont secondary zoospores with a large vacuole.

\section{E. Gomphonematis}

Figs. 29-25. Cleavage stages in a zoosporangium.

Fig. 26. Anteriorly biflagellate primary zoospore.

Fig. 27. Empty sporangium with two exit papillae. Zoospores encysted at one prapillae, while those which emerged from other papilla swan away.

\section{E. Liemophorae}

Fig. 2R. Portion ot a Licmophora cell showing a naked anoelocid uninucleate thallus with pseudopods at lett: two uninucleate thalli with walls near lost mucleus in center; and a tetranucleate thallus at right.

Fig. 29. Mature sporangium witl cleavage segments.

ligs. 30, 31. Anteriorly biflagellate primary zoospores.

Fig. 32. Zoospores encysted at mouth of exit papillae.

Fig. 33. Parthenogenetic resting sprore (?) in rudimentary oogonium (?).

Fig. 34. Antheridiun (?) and oogonium (?) with oospore (?) connected ly fusion canal (?).

Fig. 35. Resting spore of $E$. perforans. 
PLATE 5

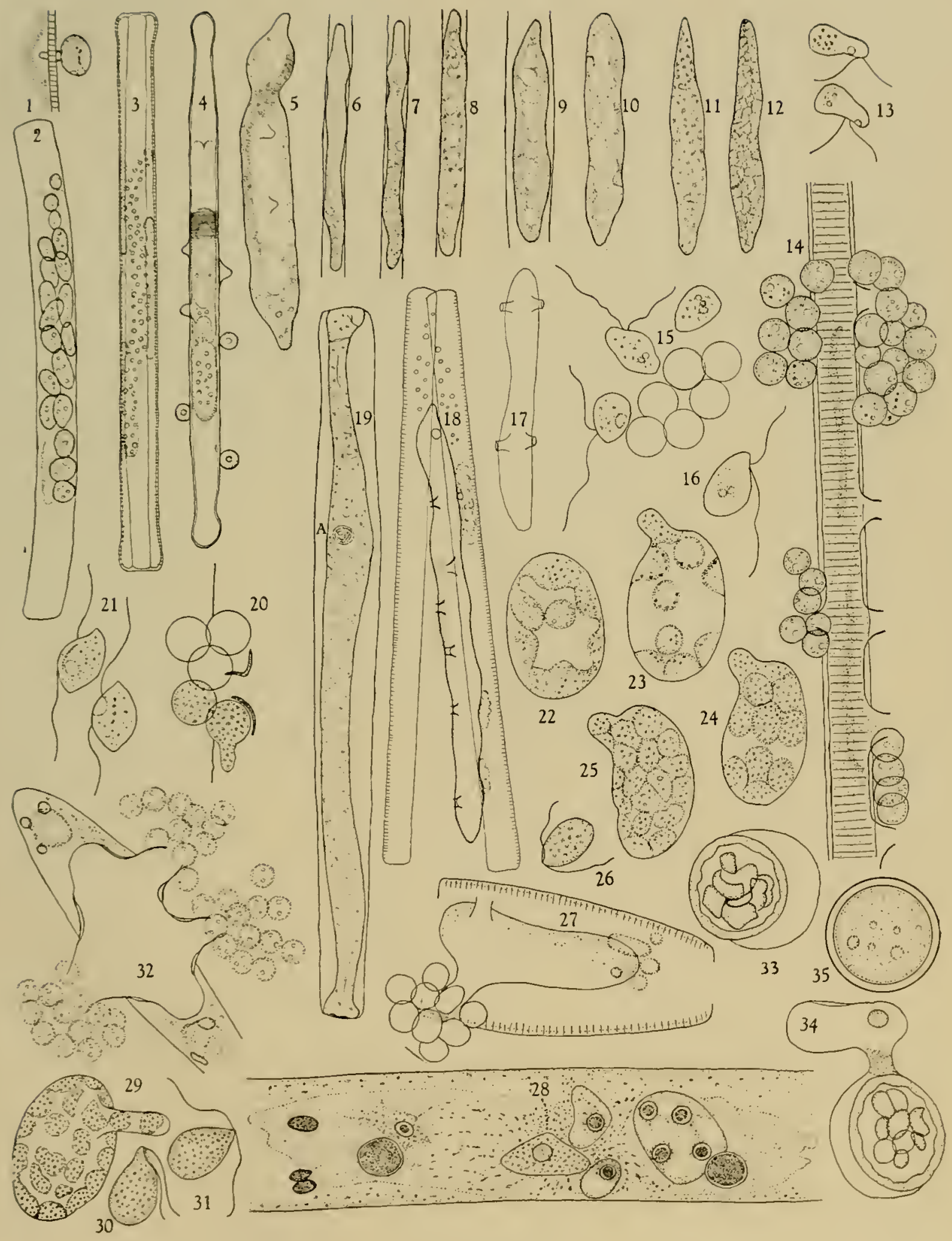


that the method of cleavage is fundamentally different in the Saprolegniaceae but primarily centrifugal in direction, because of the presence of a large central vacuole which displaces the protoplasm in a comparatively thin layer at the periphery. Doubtless when clearage in Eurychasma and Ectrogella has been intensively studied from fixed and stained material the fundamental similarity of the process will become quite evident.

The secondary zoospores emerge from the cysts after a short dormant period (figs. 15, 20, 27). In $E$. Gomphonematis the numerous small granules present in the primary swarmers fuse during the encysted stage and form a single large refractive globule. These zoospores are oval and pyriform in shape with two unequal flagella inserted laterally or close to the anterior end. In motion the shorter flagellum is directed forward, while the longer one is dragged along behind (figs. 16,21 ). Unlike those of the uniflagellate rhizidiaceous chytrids the zoospores swim more evenly and do not dart about in a zigzag path.

Resting spores have so far been observed only in E. perforans (fig. 35) and E. Licmophorae (figs. 33, 34). In the former species no sexual fusion has been reported and the spores appear to be nothing more than spherical, thick-walled, encysted thalli or sporangia. In the latter species, however, Scherffel figured a thick-walled spore lying in a thin envelope with a lyaline thin-walled, empty vesicle or conpanion cell attached to one side by a broad tube (fig. $34)$. He regarded the resting spore as a oospore in a rudimentary oogonium which has bcen formed by fusion of the protoplasts of an antheridium and egg cell through a broad conjugation canal. Scherffel did not olserve aetual fusion in E. Licmophorae, and figure 34 may relate to nothing more than an irregular thallus, the content of which contracted into a thick-walled resting spore in the larger of the two lobes, as is suggested by figure 33. Resting spore formation of this type is not uncommon in species of the lower simple fungi, i.e., Olpidium gregarium, Cantenaria Anguillulae, etc. The evidence of sexual reproduction in Ectrogella is thus very meager and inconclusive, and until further proof is found the presence of sexuality in this genus must be regarded as highly questionable.

E. BACILLARIACEARUM $/ 0 p \mathrm{f}, 188$. , l.c., pl. 16, figs. $1-2 t$.

('ymbanche fäckei l'fitzer (pro parte), 1869. Sitz'b. Niederrh. Ges. Nat. Heilk. $26: 2: 21$.

Olpidium gilli de Wildeman, 1896. Ann. Soc. Belge Micro. 90:41; Gill, 1893. Jour. 1Roy. Micro. Soc., $1893: 1$, pl. 1 .

Zoosporangia solitary or up to 30 in a cell, smooth, hy aline, oval, elongate, cylindrical, vermiform, $4-9 \mu$ in diameter and up to $200 \mu$ in length with 1 to 11 short exit tubes or papillae in single or opposite rows, which project between the separated valves of the diatom cell on the girdle side and stain intensely violet with chloro-iodide of zinc. Zoospores diplanetic; primary zoospores pyriform, $2 \times+\mu$, with a refractive spot at the anterior and numerous granules at the posterior end and two rudimentary (?) equally long, $4 \mu$, flagella inserted laterally in a slight indentation near the anterior end; emerging fully formed and swimming directly away, later coming to rest and encysting; secondary zoospores, oval $2 X+\mu(?)$ with a tapering anterior end, near which arise two unequal flagella, and one to several refractive granules near the posterior end. Resting spores unknown.

Parasitic in Synedra lunalaris, Synedra sp.; Gomphonema sp. and Pinnularia sp. in Germany (Zopf, l.e.); Synedra sp. and Gomphonema sp. in Belgium (de Wildeman, '90, '93, '9., '95); Pleurosigma attenuatum, Synedra sp., Pinnularia sp., Cocconema lanceolatum and Nitzschia sigmoidea in England (Gill, '93; Smith and Ramsbottom, '17); Synedra ulna, Pinnularia sp., Gomphonema sp., and Meridion circulare, in Hungary (Scherffel, '25; Domjan, '35), and Pinnularia sp. in New York, U. S. A. (Sparrow, '33). This species was found in great abundance in Nitzschia sigmoidea by the anthor during the summer of 1942 at Beaufort, North Carolina.

'This is the type species of the genus, and although it apparently occurs abundantly in nature it is still incompletely known. Petersen regarded it as a probable spceies of Pleotrachelus with numerous exit tubes arranged in rows.

The question of whether or not the organism which Gill described relates in entirety to this species has been the subject of much diseussion. As is indicated in the synonomy above de Wildeman lolieved that the sporangia shown in figures 1-8 by Gill relate to a species of Olpidium since only a single elongate exit tube is present, while the thalli shown in figure 9 relate to $E$. bacillariacearum. Minden recognized $O$. gilli as a valid species, but Scherffel was undecided about its ralidity. He maintained, however, that it as well as Van Heurck's fungus is not identical to Zopf's or to any of his own species of Ectrogella, and helieved that figure 9 of Gill may relate to E. bacillariacearum or Aphanomycopsis. Scherffel failed to observe Zopf's species in Pinnularia and Gomphonema, and he was accordingly of the opinion that Zopf's figure 23 , plate 16 , may relate to Lagenidium brach ystomum.

Van Heurck ('99, p. 6.t, fig. 22) figured and described an endophytic parasite with a single elongate exit tube in Plenrosigma angulatum which is strikingly similar to Gill's organism. Van Heurck believed that his fungus may be identical to Gill's species.

As Fiseher ('92) pointed out. Pfitzer's Cymbanche föclei may perhaps relate in part to $E$. bacillariacearum. Zopf ('84, '85), however, regarded it a member of the Saprolegniaceae. It is also possible that the thick-walled strncture with an eccentric vacuole which l'fitzer described may be the resting spore of this species. Pfitzer deseribed this spore as continining small starch grains like those found by Pringsheim in Saprolegnia, but these bodies are ob- 
viously of a different nature than starch grains. The structures deseribed for loiche as spores of dintoms, whicle l'titzer interpreted as a part of ("ymbanche firchei, relate to a specie's of the Myxozodidia. (iym-

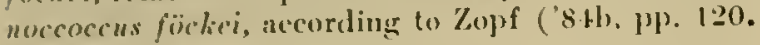
İ(i) and lischer.

E. PERFORANS l'etersen. 190j. (Over. K'pl Dinsk. Vielens. Silsk. For. (j) : Hiti, tigr. I"11, I-s.

Zoosporangia solitary or up to 5 in a cell. smooth hraline; wall staming light violet with chloro-jodide of zinc: spluerical $20-35 \mu$, oval, clongate, $22-23 \mu$ $\times 20-10 \mu$, sometimes slightly irregular, and becoming partially extramatrical at maturity with 1 to 8 short. very broad. $9-12 \mu \times 8-10 \mu$, exit tuhes. Zoospores hialine with a refractive globulc at the anterior cond, cmerging fully formed and swimming directly away, pyriform and somewhat eurved with the two flagella attached anteriorly (?) and oppositely directed in swimming. relitive lengths of Alagella unknown; motion during swimming uneven and twisting. Rest spores spherieal, 1t-19 $\mu$. hyaline, smooth, thick-walled witl one large or several smaller refractive glohules; gremination unknown.

Parasitic in Licmophora Lyugbyei, Licmophora sp.. and Synedra ulna in Denmark (Petersen, l.c.; Siparrow, "31); Licmophora abbreziata, Striatella unipunctata and Vorticella sp.. in Mass., U. S. A. (Sparrow, $36 \mathrm{~h}$ ), causing distortion of host cell and complete destruction of the liost protoplasm. The author has recently ('+2) olsserved this species in great ahundanee in $L$. abbreziata and $L$. flagellata at Beaufort, North Carolina.

This species appears to be a virulent parasite and nay attain epidemie proportions in Licmophora, according to Sparrow (' $36 \mathrm{~h})$. In the shape of its sporangia with numerous hroad exit tubes this species is strikingly similar to $\%$. Licmophorae, and Schertfel was accordingly of the opinion that the two species may prove to he identical. It is to be noted, however, that the base of the exit tubes of $E$. perforans is not thickened and does not form a spreading apparatus as in E. Licmophorae, nor do its zoospores cucyst in a gromp at the month of the exit canals as far as is $110 w$ known. It is primarily for these reasons that Sparrow ('3.t) regarded F. perforans as a distinct species. It is not improbable, however, that when intensive comparative studies have heen made of both species and their range of rariation worked out, they may prove to be identical.

Sparrow ('36) deseribed the zoospores as possibly anteriorly biflagellate with both flagella oppositely dirceted in swinming. He was unable to determine the relative lengths of the flagella, and it is not known whether the anospores are iso- or licterocont. Sparrow found that as much as cighty-eight per cent of the Licmophora cells in a single mount may he parasitized by this species. The zoospores are capable of attiseking other hosts as well. since species of Forticella which ingest free swinming zoosporcs may in turn be attacked by the swallowed parasites and completely destroyed.
No couclusirc rvidenee of sexuality has been found in this species. P'etersen found isolited thickwalled resting spores (fig. 35) in several instanees, hut these were not accompanicd by empty antheridia or companion cells. Spriprow (31), on the other hand, believed that the spores are surrounded by it thin envelope. In one instance lie found an cmpty hemispherical cyst, $3 \mu$ in diameter, attiched to is fully mature sjore. However. no stinges of fusion were olsserved.

E. MONOSTOMA ticherffel, l.e., p. 8, j1. 1, figs. 10-19.

Zoosporangia solitary, elongate. tulular, somcwhat spindle-shaped, $i-8 \mu$ in diameter, slightly swollen in the median region from which a single, short, $2-3 \mu$ thick, cylindrical exit tube or papilla arises: exit tube and part of the sporangium wall staining intensively violct with chloro-iodicle of zinc. Primary zoospores aflagellate, gliding out of the sporangium and encysting in a group at the mouth of the exit tube; individual eystospores spherical, $6-8 \mu$ in diameter, wall showing a marked cellulose reaction; secondary swarmers, lemonshaped, $8 \mu$ long, with a ventral furrow, heterocont (?), shorter flagellum directed forward and the longer one dragged along behind while in motion. Resting spores unknown.

Parasitic in Synedra ulna in Hungary; Pinnularia sp. in New York, U. S. A. (Sparrow, 33) and Synedra sp. in England (Sparrow, '36a).

Aeeording to Scherficl and Sparrow, this speeies differs from the other members of Ectrogella only by the presence of one short exit tube. Except for this eharacter and the median bulge (fig. 19) its thallus and zoosporangia are identical to those of $E$. bacillariacearum whieh parasitize the same host. Obviously the presence of one or more exit tubes is not always a distinctive specific character. However, the secondary zoospores of E. monostoma appear to be considerably larger $(8 \mu$ long) than those of $E$. bacillariacearum which Zopf reported to be only 2 to $3 \mu$ in diameter. Zoospore size is a more constant specific cell eharacter, and if further observations confirm this difference the validity of $E$. monostoma will be established.

E. GOMPHONEMATIS Scherffel, l.c., p. 9, pl. I, figs. 20,21 .

Zoosporangia solitary, oval, oblong, egg-shaped with 1 or usinally 2 short exit tubes located at the cnds. Zoospores diplanctic, primary zoospores eggshaped and somewhat elongate. $3 \mu$ long, with a few highly refractive granules and the two cyual flagella, slightly longer than the spore body. inserted almost at the apjeal end; swarming within the sporangia, later cmerging singly and swimming away (?) or encysting in a group at the mouth of the cxit tubes: gramules fusing during eneystment to form a large refractive glohule as in some rhizidiaceous ehytrids; germination of cysts, and structure of secondary zoospores unknown. Resting spores unknown. 
Parasitic in Gomphonema micropus in Hungary.

Except for the oval shape of its thallus and zoosporangia (figs. 22-25) this species does not appear to have any particularly outstanding characters. Scherffel believed that the primary zoospores (fig. 26) may encyst at once at the month of the exit tube (fig. $27 \mathrm{~A}$ ) as in E. bacillariacearum and in Achlya species or swin away as in Saprolegnia and encyst later. Until more is known ahout this organism its validity as a distinct species will remain doubtful.

\section{E. LICMOPHORAE Seherffel, 1.c., p. 10, pl. 1, figs. 2?-30.}

Zoosporangia solitary or up to 10 in a cell, spreading open the diatom shell and becoming partially extramatrical at maturity; oval, slightly elongate with 1 to 10 exit tubes which are inflated, thickwalled, and flask-shaped at the base and give the mature sporangium and irregular, somewhat stellate appearance. Zoospore diplanetic; primary swarmers pyriform, $3 \mu$ long, with two equal, apically inserted flagella which are approximately twice as long as the spore body; swarming within the sporangium, emerging singly and encysting in a group at the mouth of the exit tube; individual cysts $3.5 \mu$ in diameter: germination of cysts and structure of secondary swarmers unknown. Resting spores single, hyaline and spherical, $12 \mu$, smooth and thickwalled; with several irregular refractive globules, lying in a spherical, $14 \mu$ in diameter, cell or envelope which may be connected by a short broad canal or tube to an oval hyaline vesicle or companion cell; germination unknown.

Parasitic in Licmophora sp. in Hungary.

As has heen noted before. Scherffel regarded the resting spore as a fertilized egg in a rudimentary oogonium, and in this respect he believed that $\dot{E}$. Licmophorae may be closely related to A phanomycopsis and Olpidiopsis. This species also shows considerable resemblance to kurychasma dicksonii and $E$. perforans by its broad exit tubes and partially extramatrical zoosporangia. Whether or not it is distinct from the latter species remains, however, to be seen.

\section{EURYCHASMA}

\author{
Magnus, 1905. Hedwigia $\$ 4: 3+\%$.
}

(PLATE: 6)

Thallus intramatrical when young but becoming partially extramatrical at maturity; oval, ellipsoid, pyriform, dome-shaped, angular or irregular; transformed completely into a zoosporangium; wall of mature thallus well defined and showing a marked cellulose reaction when tested with chloro-iodide of zinc. Zoosporangia solitary in a cell, hyaline. smooth, oval ellipsoid, pyriform, angular or irregular with 1 to 3 broad exit papillae or short tubes which are usually completely extramatrical. Zoospores either
(1), coming to rest and encysting in the sporangium, forming thus a network of polygonal cysts as in Dict yuchus, later emerging from the cysts into the central portion of the sporangium and then swimming out; or (2), swimning out at once and pausing for a few moments at the mouth of the exit papilla, then gliding away without encysting. Zoospores ellipsoid and pyriform, hyaline, containing several small granules; heterocont with the two flagella attached near the anterior end. Resting spores unknown.

This genus includes at present two incompletely known species which are parasitic in brown and red algae. Our knowledge of the genus is hased almost cntirely on $E$. dicksonii the life cycle of which is illustrated in Plate 6. Until the last decade the zoospores were described as posteriorly uniflagellate, although in 1925 Scherffel predicted that further study would show them to be biflagellate. Dangeard's and Sparrow's studies in 193.1 confirmed this prediction as is shown in figures 1 and 2. According to Sparrow, the zoospore comes to rest and encysts on the host cell (fig. 3) and soon forms a germ tube which penetrates the host cell wall. The content of the zoospore passes into the host as a naked body leaving the spore case and penetration tube on the outside (fig. 4 ) as in Ectrogella, $P y$ thiella, Olpidiopsis, etc. Within the host cell the young parasite appears as a naked amoeboid protoplast (fig. 6) with one to several pseudopod-like extensions and resembles the early stages of Ectrogella Licmophorae. According to Lowenthal, it assumes a position near the host nucleus (fig. 6), but whether or not this migration takes place by independent amoeboid movement has not been determined. Lowenthal believed that it remains naked and surrounded by the host protoplasm until it is fairly large and multinucleate (fig. 7). In the early developmental stages it is hardly to be distinguished from the host protoplasn in living material, but as it increases in size it becomes very vacuolate (figs. 8 , 9 ), according to Sparrow. Petersen ('05) described four distinct and successive maturation stages which he believed are also characteristic of the Chytridiales as a whole. At that time, however, it was generally believed that Eurychasma belonged among the chytrids. Since doubt has been expressed about the sequence of these stages it is worthwhile to enumerate them at this point: 1 , Stade protoplasmique ordinare characterized by dense, almost avacuolate protoplasm and division of the nuclei; 2 , Stade globuleux in which nuclear division and zoospore differcntiation have been completed, and the sporangium is filled with numerous closely appressed globules of an oleaginous nature; 3 , Stade ecumeux characterized by an increase in sizc of the sporangium, highly vaciolate protoplasm with the nuclei lying in the pcripheral region and the cytoplasmic bridges separating the vacuoles, and by the disappearance of the outlines of the zoospores; and 4 , Stade a zoospores regulierement disposes contre la membrane in which the zoospores are regularly distributed 
a round the inner periphery of the sporangium. In light of what has siner he'n diseorered albont zonsporogenesis in Iythiella, Fetrogella, and other similar senera. it is very doubtful that numerous larac vaenoles are present in the zoosporangium after the \%onspores have been debinited. as l'otersen reportied for stade ecumeur. Before cleavige be gius the vacuoles doubtlens fuse to form oue or more larger central ones (fig. 12) which apparently disappear when the centritugal deaving furrows reach the plasma membrane, as Scherffel and Couch have dencribed for Eetrogella and Pythiclla. It is, furthermore. questionable that nuclear division has been completed at the time of the stade globuleux. Petersen's studies relate only to lirine material, and in such preparations it is impossible to determine when nuclear division is finished. Petersen's report that these stiges are chitracteristic of the Chrtridiales as a whole was denied by Scherffel who maintained that they are typical only of the Saprolegniaceae and their close relatives. Both he and Lowenthal reported that the zonspores are dolimited simultaneously, hut this is probahly incorrect. Cleavage is doubtless progressire as has becu shown for other closely related gencri.

Aecording to Petersen, the zoospores hecome very active within the sporangium, and after a while come to rest and encyst around the inner periphery. They thus form by inutual contact and pressure a periphcrai layer of polygonal cysts-the so-called "netsporangium" stage (figs. i 1, 11, 15). Sparrow, on the other hand, observed that the zoospores usually cmerge at once and swim away (fig. 7 ) after a bricf pausc at the mouth of the exit tube. He found the "net-sporangium" stage only occasionally and coneluded therefore that its oceurrence may possihly be a reaction to adverse environmental eonditions. Nevertheless, two types of zoospore helavior have becn observed, one as in Saprolegnia and the other as in Dictyuchus. It differs from that of the latter genus, howerer, by the fact that the zoos jores which emerge from the eysts do not pass through the sporangium wall lut into the central cavity and then out through the exit tuhes. Whether or not those which emerge directly and at once from the sporangium cucrat after a period of motility as in Saprolegnia has not been determined. Petersen and Scherffel nometheless regarded the zoospores of liurychasma as diplanetic - the first motile stage occurring within the sporangium and the second on the outside. So far no one has figured or deseribed the shape of the primary swarmers within the sporangium, nor the number, relative lengths, and position of their Aagella.

The effect of Larychasma on the host cell varies considerahly as Rattray and subsequent workers have pointed out. In some instances the infected cells may not be greatly hypertrophicd, while in other cases they una he several times their normal size. Acoording to Sparrow, lypertropley hegins shortly after the entry of the parasite (figs. $3,1,5)$ ). However, infected cells are not stimulat by the parasite to divide; nor do the adjacent henlthy eells cularge or divide as far as is now known. Ilypertrophy is thus contined to infected cells. 'The en-

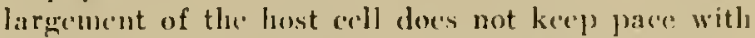
the errowth of the parasite, sinee the lister eventualy hursts out of the confining host wall and is often onc-third to one-lalf extramatrical at maturity as is shown in figures $10,11,1 \%, 18$, and 19 . According to lowentlan], destruction of the coll contents does not oceur at once in Pylaiella cells, since the nuclens and plastids may be cleariy diseerned even when the parasite almost completely fills the cell. "The pyrenoids, howerer, disaplear very shortly. Sparrow, on the other hand, reported that the plastids of Striaria soon become discolored and disintegrate, and the degencrated protoplasm which is not utilized hy the parasite eventually forms a brownish-green layer around the mature parasite.

Prior to the diseovery that the zoospores of Furychasma are biftagellate, this genus was generally included in the family Olpidiaceac of the Chytridiales, althengh as carly as 1905 Petersen had made it the type genus of a new family. Eurychasmaceae, which he placed near the Olpridiaceac. Scherffel ('25), however, merged Furychasma with Ectrogella and included it in the saprolegniaceae, although it was not then known that the zoospores are hifagellate. He did this on the grounds that the thallus hursts out of the host cell as in specics of Ectrogella; that the appearance of the protoplasm and the stages of zoosporogencsis are similar in both genera, and on the belief that the zoospores are typically diplanetic. It is to be noted, however, that the "net-sporangium" stagc has not been found in species of Letrogella. Furtlicrmore, resting spores arc unknown in Eurychasma, and since it is not improbahle that they may be found to be quite different from those of Ectrogella, Eurychasma is retaincd here as a scparate genus for the time being in the family Ectrogellaceac.

E. DICKSONII (Wright) Magmus, l.c., figs. 1-3.

Rhizophidium dirksonii Wright, 1879. 'Trans. Roy. I rish Acad. $26: 369$. PI. 3.

Olpidium dicksonii (Wright) var. Strinter Wille, 1 s99. Viclensk, Selsk. Skr. Math. Nat. lilasse 1, 3:2. Pl. 3. Eiclrogetla alirksouii (Wright) Scherffel, 1933. Ireh. l'rotist'k, 52:1, 11.

Zoosporangia solitars, hyaline. smooth, oval, ellipsoid, somewhat elongate, $20-25 \mu \times 10-80 \mu$. angular and slightly irregular with $1-3$ short, hroad. extramatricil exit tubes or papillae. Zoospores ovil, pyriform $3 \times 5 \mu$. with two unequal Hagella inserted near the anterior end. Resting spores unknown.

l'arasitic in Fictocarpus granulosus, E. crinitus, Pylairlla littoralis and Striaria attenuata in Ireland (Wright. l.('.; Johmson, '09); Ectocarpus conferzovides, $K$. crinitus and $E$ pusillus in Austria (IIauck, 'TS) ; H. siliculosus in Scotland (Rattray'. '81) ; Striaria attenuata var. fragilis and Yylainla littoralis in Norway (Wille, '99; I,owenthal, 0.5); 
P. littoralis, Stietyosiphon tortilis, Striaria attenuata, Alinetospora sp., Ectocarpus sp., E. confervoides, E. sandrianus, and Punctaria sp., in Denmark and Greenland (Petersen, '05; Sparrow, '34); Stictyosiphon corbierei and Ectocarpus sp. in France (Pierre Dangeard, '34), causing marked hypertroplyy and destruction of the infected cells. Magnus ('05) claimed to lave seen it in marine algae at Kiel also as early as 1872 .

As is evident in the synonomy given above this type species of the genus has undergone numerous taxonomic changes. Wright, Hauck, Rattray, Fischer ('92) and Schroeter ('97) placed it in the genus Rhizophidium, but in '99 Wille transferred it to Olpidium because of the lack of a rhizoidal system. In 1905 Magnus called attention to the fact that the sporangia burst through the host ccll and become partially extramatrical with one to several broad exit tubes or papillae, characters which are unlike those of Olpidium; and he accordingly created the new genus Eurychasma for Wright's species. Finally, in 1925, Scherffel transferred it to Ectrogella.

This species had doubtless been seen hefore its discovery by Wright and mistaken for a stage in the life cycle of its host. Wright and Rattray were of the opinion that the reproductive organs of certain marine algae described by Harvey (1862) and Kiitzing $(1855,1861)$ relate to this species. Magnus, however, claimed that the latter workers had studied and figured Chytridium plumulae.

E. SACCULUS Petersen, 190\%, Overs. K"gl. Dansk. Videns. Silsk. Forl. (5) : 477 , figs. VIII, 5, 8, 9.

Zoosporangia solitary, largely extramatrical, hyaline, smooth, irregular, elongate, $80-184 \mu$ high, with one to three broad exit tubes; intramatrical portion lobed and irregular. Zoospores and resting spores unknown.

Parasitic in Rhodymenia palmata and IIalosaccion ramentaceum in Greenland, causing marked hypertrophy and destruction of the infected cell.

According to Petersen, this spccies differs from E. diclisonii by the lohed and irregular shape of the zoosporangia, particularly the intramatrical portion. Although he did not observe the zoospores, he belicred that they may behave in the same fashion as those of the previous species. On the basis of prescnt-day knowledge concerning Eurychasma it appears to be a very doultful species. and further study may prove it to be identical to $E$. dichsonii. Scherffel, on the other hand, believed that it may be a species of Ectragella.

Whether or not Gran's ('00) Olpidium Lauderiae parasitic in Lauderia borralis belongs in Eurychasma or Ectrogella is a matter of dispute. Petersen (l.e., p. 469) regarded it as a questionable species of the former genus and renamed it $2 \%$. Lauderiae. Scherffel thought that it may prove to be a member of Ectrogella, and named it Eetrogella Lauderiae.

\section{EURYCHASMIDIUM}

\author{
Sparrow, 1936. Biol. Bull. 70: 241.
}

(PLATE 7)

Thalli intramatrical, solitary or numerous, unicellular, spherical, ellipsoid, irregular and lobed. Zoosporangia solitary or up to eight in a cell, variouslyshaped with one or numerous exit tubes which may end flush with the surface of the host cell or extend beyond it. Zoospores diplanctic, encysting in polygonal cysts at the month of the exit tubes, emerging later and leaving the empty cysts behind; relative lengths and position of flagclia unknown. Resting spores unknown.

Sparrow created this genus for the parasite of Ceraminm which Magnus first discovered in 1872 and described as Chytridium (Olpidium) tumifaciens. As is slown in Plate 7 it is very similar to

PLATE 6

\section{Eurychresmet dicksonii}

(Figs. 1, 3-5, 8-11, 14-17 after Sparrow, '31; fig. 2 after Dangeard, ' 31 ; figs. $6,7,12,13$ after Lowenthal, '05; fig. 18 after Wright, '77.)

Fig. 1. Fixed and stained biflagellate heterocont zoospores.

Fig. 2. Biflagellate heterocont zoospores with a tapering anterior end near which the flagella are attached.

Fig. 3. Early infection stage of Striarif cell.

Fig. 4. Enlarged algal cell with zoospore case and infection tube attached.

Fig. 5. Enlarged algal cell with small parasite within.

Fig. 6. Naked young uninucleate amoela-like parasite with several pseudopods lying in cytoplasm of a Pylaiella littoralis cell; host nucleus at lett.

Fig. 7. Naked tetranucleate parasite in which only two nuclei are visible; lying in the vacuole of a gametangium of Pylaiella.

Figs. 8-9. Distended host cells with vacuolate parasites; exit papillae beginning to form.

Fig. 10. Partially extruded parasite which has ruptured the enveloping host wall.

Fig. 11. Zoosporangium witls a peripheral layer of zoospores.

Fig. 12. Longitudinal seetion of parasite before cleavage slowing the protollasm as a thin layer lining the sporangium.

Fig. 13. Longitudinal section of sporangium after contpletion of cleavage.

Fig. 1t. A "net-sporangium" in which all but two of the zoospores have evacuated their cysts.

Fig. 15. Sporangium with two exit tubes and a peripheral layer of encysted zoospores.

Fig. 16. Portion of a "net-sporangium" showing emergence of zoospore from a cyst.

Fig. 17. Slorangium showing direct diseharge of zoospores without previous encystment.

Fig. 18. Sporangia in cells of Ectocripues grounto:us.

Fig. 19. Empty thallus of Eurychasma suceulus showing irregular sac-like character of intramatrical portion. Petersen, '05. 
PIAT'E 6
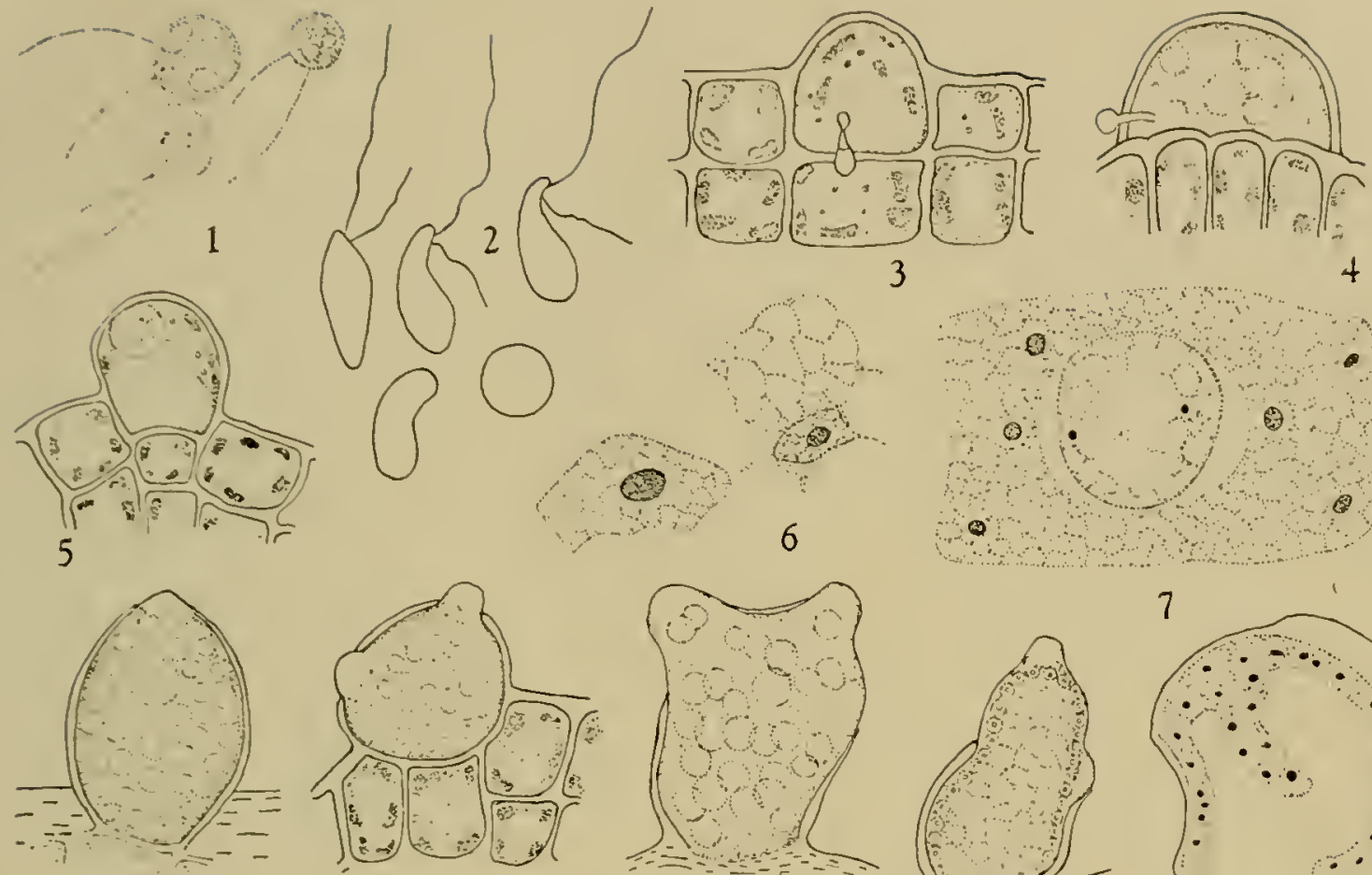

8

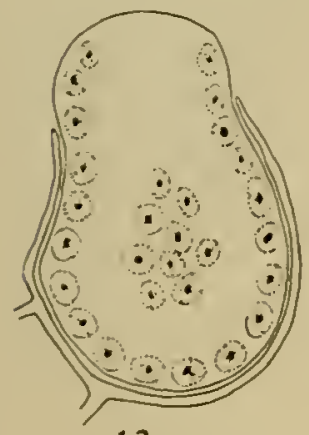

13

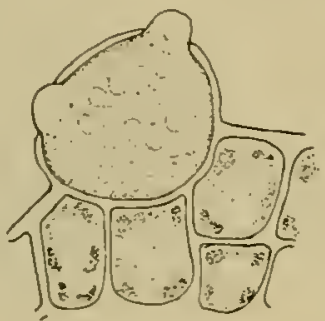

9

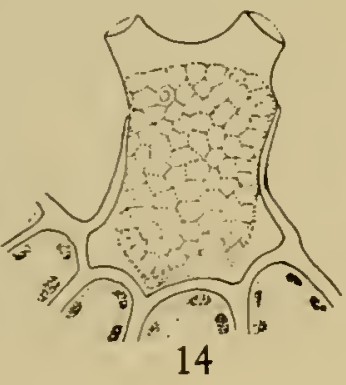

14
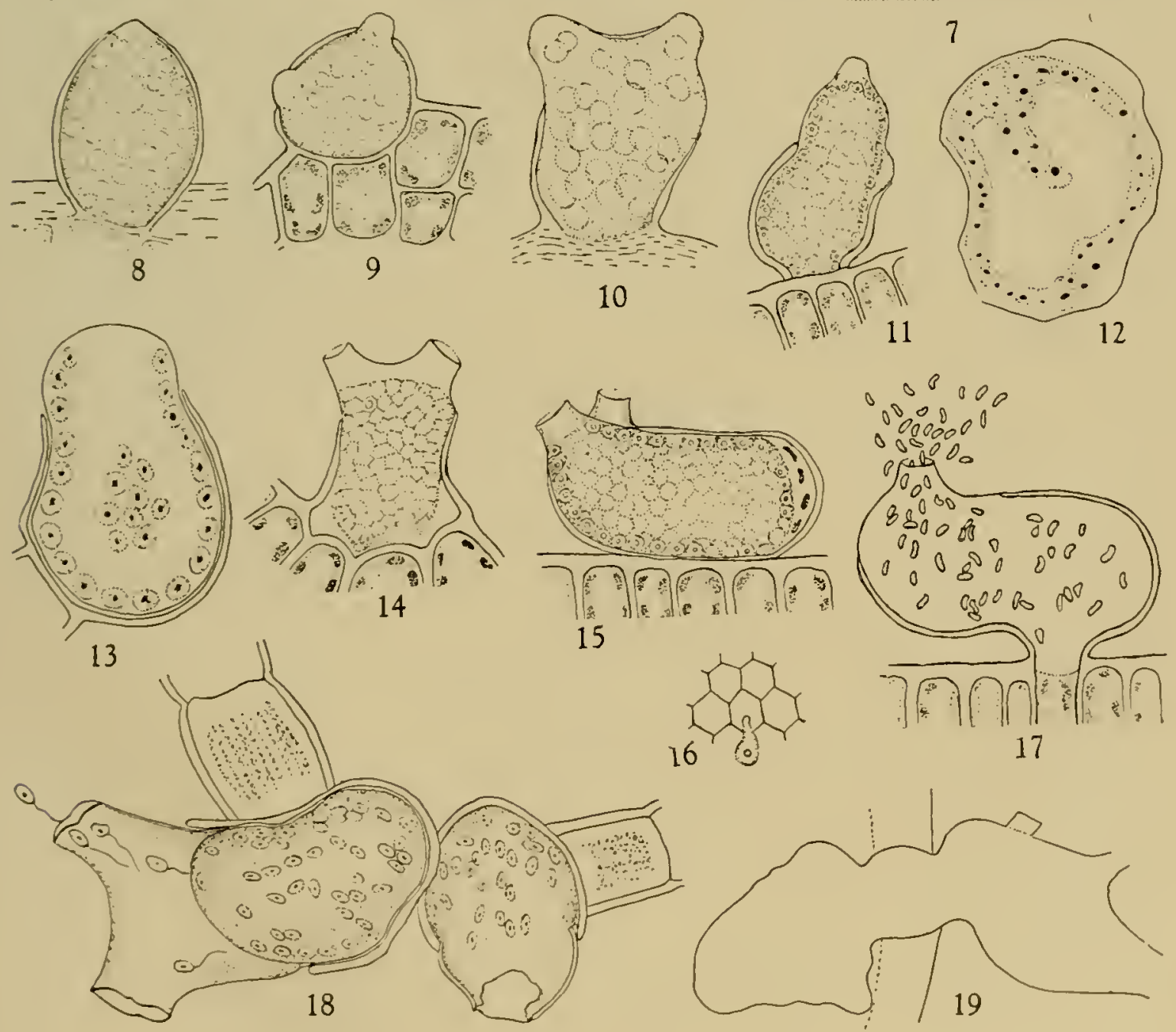

Vurychasma

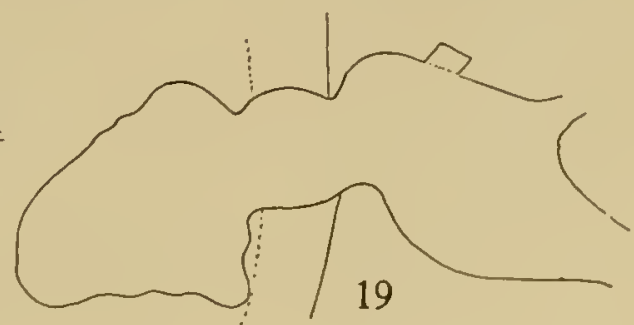


Eurychasma in method of infection and develo p- $^{-}$ ment, but, aceording to Sparrow, it differs fundamentally by the presence of comparatively narrow exit tubes, its completely intramatrieal position in the bost, the eneystment of the zoospores outside the sporangium, and by a more pronounced effect on the host cell. However, differences in number, lengtl and diameter of the exit tubes, effeet on the host. partial or complete intramatrical development are questionable generie eharacters, and when Eurychasmidium as well as Eurychasma are more fully known they may possibly prove to be identieal.

Sparrow reported that zoospore germination and infection of the lost are similar to those of Eurychasma and Ectrogella, although he did not actually observe these processes. In a few cases. however, he found empty zoospore eases and infection tubes attached to parasitized cells (fig. 6), which suggents that the contents of the spore enter the host cell as a naked body. Multiple infection apparently occurs fairly often, since as many as eight thalli may be fomid in a single eell (fig. 3 ). The well-established thalli are easily distinguishable in the host cell ly. the presence of numerous refractive globules in the protoplasm (figs. 5-9). As growth continues the chloroplasts begin to disintegrate and the remainder of the host protoplasm beeomes quite vaenolate (figs. $6-7$ ). Concomitant with these internal changes the bost cell becomes distended and its wall greatly thickened (figs. 8-10). Infected cells do not divide, but healthy cells of adjacent nodes are stimulated to divide. There are thus formed in the vieinity of parasitized cells a number of curved stunted lateral branches (fig. 8,9) which give a bushy appearance to the infected regions of the host plant.

- The sucessive internal maturation changes in the parasite are identical to those described by Petersen for Eurychasma, including the characteristic "stade ecumeux." The final stages in zoospore formation and emergence have not been ohserved, so that it is not known whether the zoospores become flagellate and swarm within the sporangium or glide out without flagella. In either event, they come to rest and eneyst in loose masses at the mouth of the exit tuhes (fig. 10). The eystospores thus formed (fig. 11) are polygonal in shape, and after a period of quiescence the protoplasm of each eyst emerges and develops into a flagellate zoospore. Sparrow reported that the zoospores are hiflagellate, but he did not illustrate them and say whether they are iso- or heterocont, nor show at what place the flagella are attached. As far as the writer is aware the zoospores of this genus lave never been illustrated.

E. TUMJFACiENS (Magnus) Sparrow, l.e., figs. 14-21. Pl. 1, fig. 1.

Chytridium (Olpidium) tumifuciens 11 agmus, 187:a. Sitz"b. Gesell. Nat. Freunde Berlin, 187z:87. 18\%:b.
Jahresb. Komm. Untersuch. Deut. Meere Kiel $2: 61$. Pl. 1, figs. 1-16. 1873. Hedwigia, 12: 28.

Olpillum tumifaciens (Magnus) Fischer, 1892. Rabenhorst's Krypt. Fl. 1, IV: 27.

Pleatruchplus tumifaciens (Magnus) Petersen, 1905. I.c., 1). $\$ 56$.

Zoosporangia, liyaline and smooth, spherieal, $100-110 \mu$. ellipsoid, $110 \times 200 \mu$, irregular and lobed with 1 to 30 exit tubes. Zoospores lyaline with a single refractive globule, eliptical, 3 X $5 \mu$. Additional details are given in the generic diagnosis above.

Parasitie in Ceramium flabelligerum and E. acanthonotum in Scotland (Magnus, l.e.) and England (Smith and Ramshottom); a red alga in Belgium (de Wildenan '00): Ceramium sp. and (C. diaphanum in the United States (Nurray, '03; Sparrow, l.e.) : and Ceramium rubrum in Denmark (Petersen. l.e.).

According to Magnus, this species was first observed by Cramer in 185.5 (pl, H. figs. 9, 11) at Naples, Italy. who mistook it for a monstrosity of C. flabelligerum (C. spiniferum). Sparrow believed that the organism which he observed at Wood's Hole is the same as Magnus' speeies, but there are some differences in the accounts of it given by the two authors. Maguus described the zoosporangia as solitary or numerous in a cell witl one or two exit tuhes which extend eonsiderably heyoud the algal cell, but he failed to ohserve any marked thickening of the host wall. Sparrow, on the other haud, reports that the wall is abnormally thickened, while the zoosporangia may possess as many as thirty exit tubes, through which the ellipsoid, biflagellate zoospores emerge. These differences may well he due to the limited observations of Magnus, but there is nonetheless a possibility that Sparrow maly have studied a different species.

\section{PLATE 7 \\ Euryrhasmidium tumifuciens}

(Figs. 1-4 after Magnus, ' 72 ; figs. 6-11 after Sparrow, 36.)

Fig. 1. Young thalli in the apital hair cell of $C$. flabelligyru:n.

Fig. 2. Older thallus in same type of cell.

Fig. 3. Enlarget tedl with eight spherital thalli.

Fig. 4. An colarged apical cell containing a mature thallus with two broad exit tuhes.

Fig. 5. Early developmental stage of thallus in Ceraminm diapharmur.

Fig. 6. Htore mature thallus with zoospore case and infection tube still attached to the enlarging host cell.

Fig. 7. Thallus surrounded by vacuolate lost protoplasm.

Fig. 8. Thallus completely filling host cell, the wall of which is greatly thickened.

Fig. 9. tobed irregular, vacuolate thallus.

Fig. 10. Empty sjorangium with numerous short exit tubes; gromps of eystospores near the exit tubes.

Fig. 11. A group of polygonal cysts. 
I'LAL
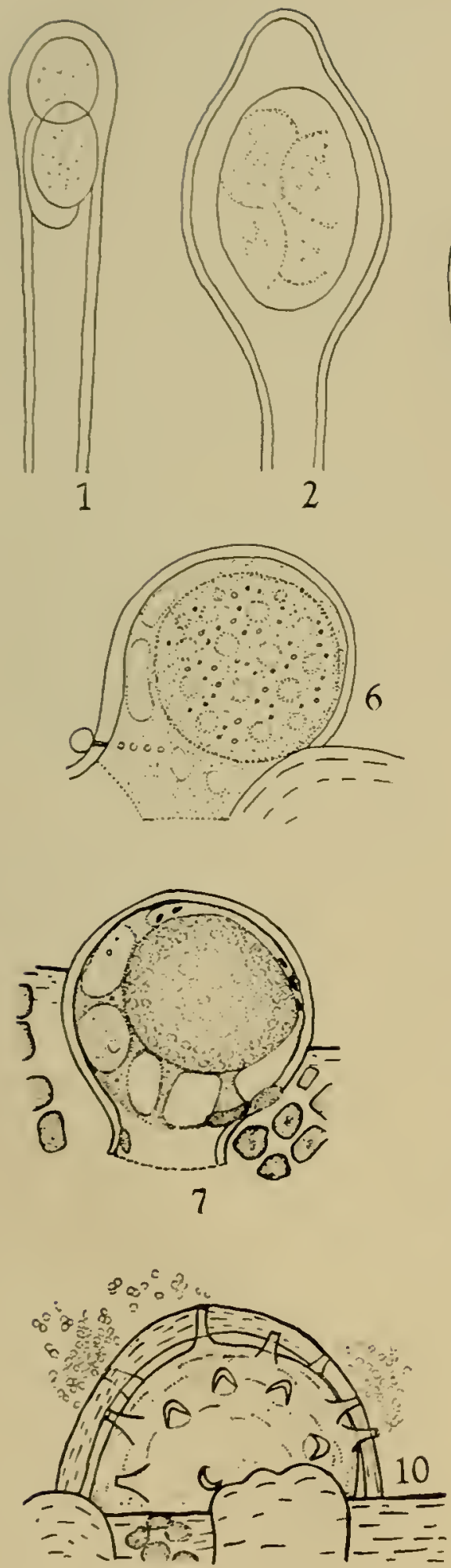
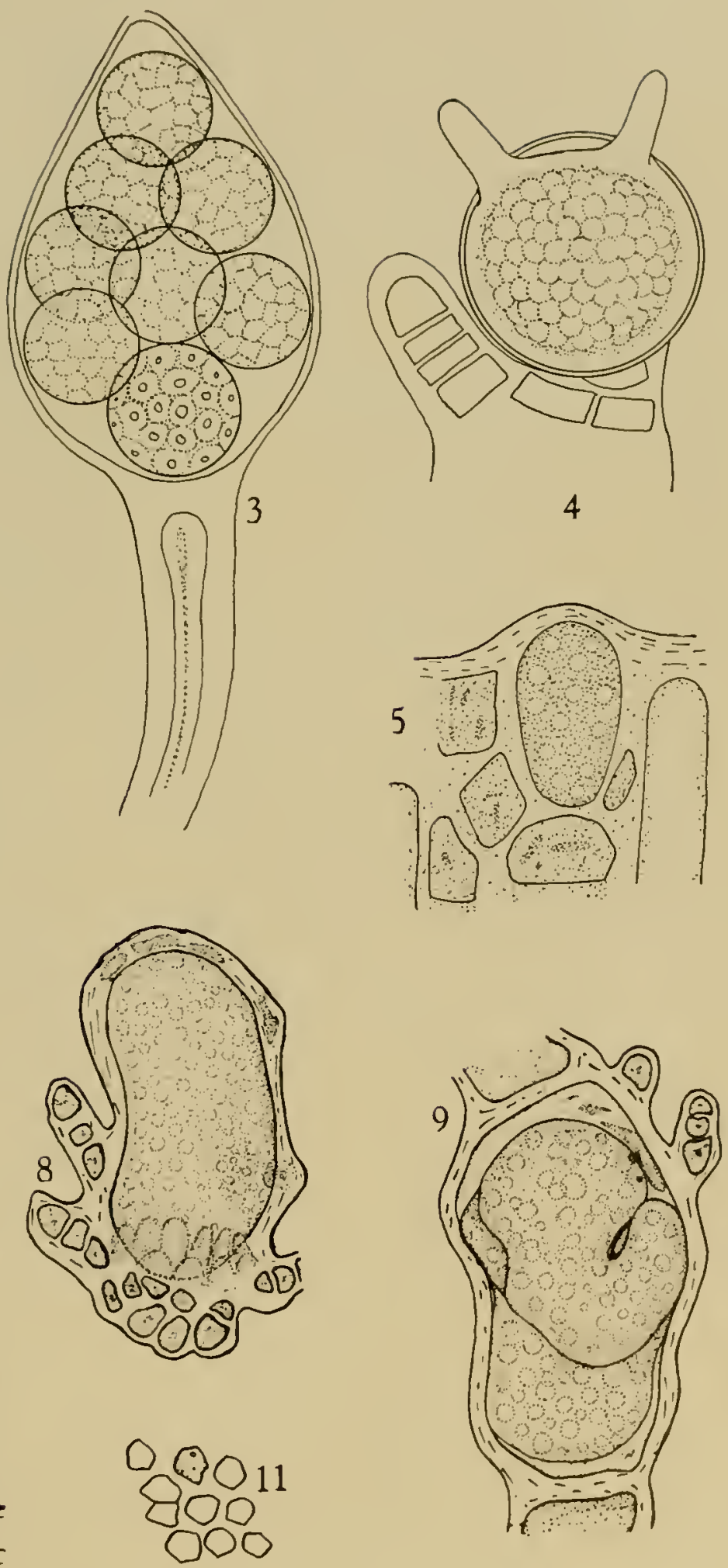

Eurychasmidium 


\section{APHANOMYCOPSIS}

\author{
Scherffel, 1925. Arch. Protistk. 52: 11.
}

(PLATE 8)

Thallus intramatrical, holocarpic, filamentous and thread-like or irregularly tubular, simple or branched. continnous or septate; walls showing a marked cellulose reaction when tested with chloroiodide of zinc; whole thallus or segments transformed directly into sporangia or oogonia (?). Zoosporangia elongate, filamentons and cylindrical or short and tubular with one to several straight, curved or irregular exit tubes which project considerably beyond the surface of the host. Zoospores diplanetic. emerging in succession without flagella and encysting in a cluster at the mouth of the exit tube; secondary zoospores grape seed-shaped with a ventral furrow and conspicuous vacuole, isocont (?) or heterocont (?). active shorter flagellum directed forward in swimming with the longer one dragging behind; swimming movement relatively slow and even, not darting. Oogonia questionable. Resting spores or oospores (?) single or several in thallus or segments thereof; parthenogenetic (?), germination unknown.

Scherffel regarded this genus as closely related to Ectrogella monostoma and included it in the Saprolegniaceae near Aphanomyces hecause of its long thread-like zoosporangium and the formation of zoospores in single linear rows. He furthermore believed that the thalli of Aphanomycopsis with their incipient resting spores should be interpreted as rudimentary oogonia containing one or sereral egg cells which develop asexually or parthenogenetically, a viewpoint which was subsequently accepted by Sparrow ('33) and Coker and Matthews ('37). The latter workers, however, included Aphanomycopsis in the family Ectrogellaceae, and later on Sparrow (' 12 ) followed this classification. Tokunaga (' 33 ) on the other hand, placed it in the Lagenidiaceac. Scherffel pointed out that this genus differs from A phanomyces by the lack of well differentiatcd zoosporangia and oogonia, but Tokunaga found the former structures to be strikingly like those of Lagenidium, as is shown in figures 15, 19, and 25. The scgments which contain the resting spores are also similar in shape to the oogonia of some species of Lagenidium. The fact that the zoospores are diplanctic, encyst in clusters at the orifice of the exit tubes, and are heterocont after emerging from the cysts does not exclude this genus from the Lagenidiaceac since such characters are also to be found in $L$. Oedogonii and Lagenidium sp., Couch. Likewise. several species of the latter genus are parthenogenetic, but each so-called oogonium forms but one sporc. On the bases of Tokunaga's studies, Aphanomycopsis is herewith inchuded only temporarily in the Ectrogellaceac. It is not altogether improbable, however, that Tokunaga's fungus may be different from Scherffel's and Sparrow's species.
Further studies are therefore essential to a better understanding of the identity and relationships of A phanomycopsis.

Scherffel reported that the zoospores which emerge from the cysts are heterocont (fig. 2), but Tokunaga described and figured them as isocont (fig. 16) without indicating any specific flagellum orientation during motility. After coming to rest on the host the zoospores form a broad germ tube which makes a small round hole in the silicified wall and penetrates the diatom cell (figs. 4,5 ). The penetration tube continues to elongate, broadens, brauches, and eventually develops into a full grown thallus, while the zoospore case and extramatrical portion of the tuhe remains attached on the outside (fig. 6). Scherffel and Sparrow reported only elongate, simple (fig. 13) or branched (fig. 17) non-septate thalli, but West and West and Tokunaga found that the thallus may be divided into segments by one to several septa (figs. $7,15,19,25)$ at maturity.

One or more exit tubes are formed as the thallus develops, but they do not perforate the diatom cell like the penctration tube, according to Scherffel. Instead, they pass out between the valves of the host when young and then develop thickened walls at the region of exit, whereby the valves of the diatom are pushed apart (figs. 13, J8). This so-called "Spreizapparat" was observed by Scherffel and Sparrow, but Tokunaga did not illustrate it in his figures of

\section{PLATE 8}

\section{A phummycopsis bacilluriucrarum}

(Figs. 1-6, 8-12, 14, 17, 18, 20-24 after Scherffel, '25; fig. 7 after West, "09; fig. 13 after Sparrow, 33 ; figs. $15,16,19,25$ after 'Tokunaga, '33.)

Fig. 1. Zoospore emerging from eyst.

Fig. 2. Laterally biflagellate heterocont zoospore.

Fig. 3. Optical cross section of same showing ventral groove and vacuole.

Figs. 4. 5. Infection of host.

Fig. 6. Empty zoospore case and infection tube on diatom eell.

Fig. 7. Branched septate thallus with zoospores elustered at $t i p$ of exit tube.

Figs. 8-11. Stages in cleavage and zoospore formation in exit canal.

Fig. 12. Branched exit tube with zoospores which failed to emerge from main branch.

Fig. 13. Two thalli with elusters of discharged 7.00spores, greatly entarged.

Fig. 14. A thallus with three exit tuhes.

Fig. 15. Branched septate thallus with several exit tubes.

Fig. 16. Bean-slatped isocont zoospores.

Figs. 17-19. Empty thalli. Note thickened basal portion of exit tube, the so-called "sp reading applaratus."

Fig. 20. Thallus with three young uospores (?), two of which occur in pairs.

Figs. 21-23. Developmental phases of the latter two oospores or resting spores.

Fig. 24. large oval resting spore.

Fig. 25. Two branched septate thalli with oospores in two expanded cells. 
PIATE S

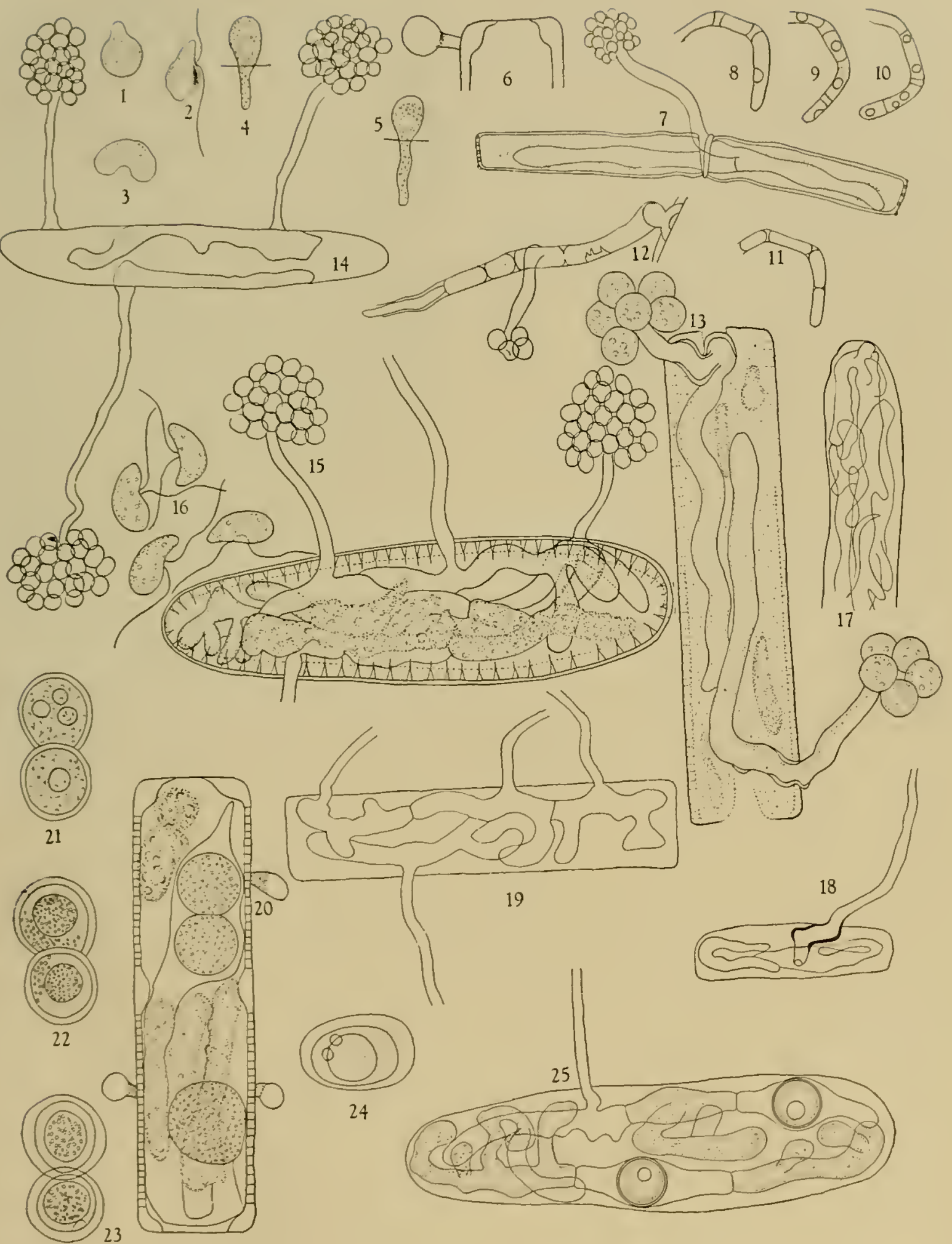

Aphanomycopsis 
this fungus. At maturity the protoplasm undergoes clcavage in the filamentous thallus and exit tubes, and forms elongate cylindrical segments (figs. 8-11) which then pass ont in suecession in a linear row as in Iphanomyces, according to Scherffel, round up, and form a cluster of cystospores at the mouth of the exit tube (figs. 7, 13, 14, 15). The lack of a differentiated sporangium in Aphanomycopsis is one of the chief characters which separates this genus from A phanomyces in Scherffel's opinion, but it may be noted in this connection that Tokunaga found the sporangia to be delimited lyy cross walls from the remainder of the thallus.

So far no evidence of sexuality has been observed in A phanomycopsis. Nevertheless. Seherffel regarded the thalli which bear one to several resting spores as rudimentary oogonia, but the evidence for this viewpoint is not convineing. In the process of resting spore formation the protoplasm of the entire thallus or segments thereof contracts into one or more globular portions (fig. 20) which develop thick, smooth livaline walls and become dormant (figs. 21-24). Whether these spores give rise directly to zoospores or a germ tube in germination is not known.

A. BACILlaRIACEARUM Scherffel, l.c., p. 14. PI. 1, figs. 31-3.5; 1 l. 9 , figs. 36-4s.

Thallus $8-10 \mu$ in diameter, continuous or septate, not markedly constricted at scpta; branches often inflated at the end. Zoosporangia filamentons and thread-like, or cylindrical, tulular, unbranched or irregularly branched and lobed, $4.8-16.8 \mu \times 150 \mu$. Exit tubes $4.8-7 \mu \times 150-240 \mu$, thickened and inflated at base to form a so-called "spreading apparatus" for separating the valves of the diatom cell. Zoospore cysts at mouth of exit tubes spherical, 6-8 $\mu$. Zoospores $7-8 \mu \times 10-12 \mu$. Entire thallus functioning as a rudimentary oogonium (?) in continuous specimen; oogonia (?) intermingled with sporangia in septate thalli, terminal or intercalary, cylindrical and medianly expanded, 15.6-26.6 $\mu$ in diameter, periplasm absent. Oospores (?) oval. $20 \times 2.4$, spherical $14.4-20 \mu$, hyaline, smooth and thick-walled with a large eccentric globule and a briglit lateral spot. For further details see generic description above.
Parasitic in Pinnularia viridis, Epithemia turgida, Cymbella gastroides, and Nitzschia sigmoidea in Hungary (Scherffel, l.c.) Pinnularia sp., and Synedra sp., in New York and England (Sparrow, '33, '36). Surirella sp., and Navicula sp., in Japan (Tokunaga,' $3 \cdot t$ ).

The parasite (fig. 7) which West and West described in Pleurotaenium ehrenberghii is very similar and probably identical to 4 . bacillariacearum. 'Their eontention that this is the same fungus which Archer ( 60 ) described from the same lost seems rery doulstful.

\section{BIBLIOGRAPHY : ECTHOGELIACEAE}

Coker, Wr. C., and Welma D. Matthews. 1937. North Amer. Flora. ?, pt. 1:1\%.

Dangeard, P. 1931. Ann Protist. 4:69.

Domjan, A. 1935. Folio Cryptogam. 2:9.

Fiseber, E. 189?. Rabenhorst's Kryptog'fl. I, IV:11.

Fïcke. Physiol. Studien $2: 43$, pl. 6, figs. $24-30$.

Gran, H. 1900. Nyt. Mag. Naturvid. 38:1Z3.

Harper, R. A. 1899. Ann. Bot. 13:467.

1914. Amer. Jour. Bot. 1:127.

Harrey, W. H. 186:. Plyycologia Australia 4. Pl. 227 , fig. 3. Hauck, F. 1878. Ocsterr. Bot. Weitschr. $28: 321$.

Johnson, T. 1909. Sci. Proc. Ruyal Dublin Soc. 12:131.

Karling, J. S. 1937. Mem. Torrey Botanical Club. 19:I.

Kiitzing, F. T. 1855. 'Tabulae Phycologieae V. Tab. 82. 186 I. Ibid., $\mathrm{X}: 26$. PI. 82.

lowenthal, W. 1905 Arch. Protistk. 5:22J.

Nurray, G. 1903. Grevillea. 21:103.

Rattray, J. 1884. Trans. Edinburgin Roy. Soe. 32:589.

Schroeter, J. 1897. Engler und Prantl, Die Nat. Pflanzenf. I, $1:$ it.

Schwarze, C. E. 1932. Mycologia 14:113.

Smith, A. I... and J. Ramsbottom, 19I7. Trans. Brit. Mycol. Soc. 6: 231 .

Sparrow, F. K. 1933. Nyeologia, 25:513. 1942, Hidl., 34:115.

__. 1934. Dansk. Bot. Ark. 8, no. 6:1. 1936 a. Jour. I inn. Soc. London Bot. $50:+17$. 1936b. Biol. Bull. $70: 236$.

Swingle, D. B. I903. U. S. Bureau Pl. Ind. Bull. 37.

'Jokunaga, Y. 1934. Trans. Sappora Nat. Hist. Soc. 13:237. Van Heurck. 1899. 'Traite des Diatomees. Anvers.

West, W., and G. S. West. 1906. Trans. Roy. 1 rish Acarl. Sect. 13, 33:77.

Wildeman, E. 1890. Ann. Soc. Miero. Belge 14:1. 1893, Ibid., 17:33. 1894, Ibid., 18:149. 1895, 1bid., 19:59.

\%olf, W. 1884. Encykl. der Naturwiss. 3:129. 


\title{
Chapter IV
}

\section{Olpidiopsidaceae}

\author{
Sparrow, 1942. Mycologria :3t: 113.
}

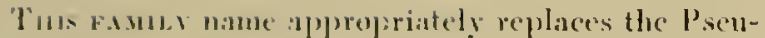
dolpidiaceste previously proposed hy petersen in 190). Since (Npidiopsis was the first genus to be created for fungri of this type it is appropriate that the family take its name from this genus. liurtlemore, there is comsiderable doubt aluout the raldity of l'sendolphdium and should this gemus prove to les srnonrums with (Mpidiopsis the name Psomdolpidiacese would no longer be deserijtive nor temalle. l'eterven included two genera. Olpidiopsis and l'sendolpidium, in his family and placed it in the Iagenidineac next to the family lagenidiaceac. sparrow likewise placed his Olpidiopsidacene in the I agrouidisles lut extended the damily to include Petersenia, Pythiella, and I'seudosphaerita as well as Olpidiopsis and l'seudolpidium. Whether or not l'seudosphaerita helongs in this fanily is open to serious question. because notling is known about the presence of sexuality and the nature of the resting spores in this erenus. In the event it proves to he a valid genus of this family. I)angeard's P'sendo-phateritaceae may also he merged with the Olpidiopsidacene. However, if I)angeard's ('33) and Mitchell's ( $(28)$ reports that the thallus segments after each nuclear divinion are correct, P'seudosphaerita differs markedly from Olpidiopsis in method of development. The present writer is nevertheless including it here temporarily for want of a better group in which to place it. Blastulidiopsis is also ineluded here provisionally for the same reason, although the development of the thallus by the enlargement, growth, and elongation of the intramatri(al tip of the germ tube is more suggestive of relationship with the Iagendiaceat than the Olpridiopsidnceac.

l'etersenia is exchuded from this family lecause the thalli of all known species, ('xecest $l$. andreii, are strikingly similar to those of Sirolpidium and l'untisma in the Sirolpidiaceae. Aceording to Sparrow's account $l$ '. andreii is applarently a species of Olpidiopsis and is acoordingly transferred to this gerulu. 'The inclusion of P'yphirlla in the Olpridiopsidaceae is likewixe: questionalile. While its method of zoosporogenesis and behavior of the zoospores is sinilar to those of some (Mpidiopsis species, the prenenec of periplanm in the so-ealled oogonium suggeste a more direct relationshif) with the l'ythiaceac. liurthermore, its walls give no positive cellulose reaction when tested with chloro-iodide of zinc, a character which is considered to be of fundanental significance in plyylogeny and relationship. As it is hercwith described, the Oljudiopsidaceat includes three incompletely known genera, l'seudosphaerita, Blastulidiopsis and I'seudolpidium in addition to
Olpidiopsis and l'ythiella, genera which future atudies may or may not prove to be colosely related. As such it includes species with markedly heterocout and isocont zoospores, and is accordingly not a very. coherent family of closely related genera. "I'lue sequence in which the genera are described below is no indieation of their primitiveness or complexitr.

\section{OLPIDIOPSIS}

Cormu, 1872. Ann. Sci. Nat. 5 ser. 15: 11t.

$$
\text { (PLATES 9 TO 13) }
$$

Prorystidium Fisch. 18s 1. Sitzolo. Plỵs. Hed. Suc. Erlangen $16 ; 60$.

Diplophysu Schroeter, 1886. Coho's Krypturtfl. Schlesiens 3: 195.

Olpidiopsis (Cornu) Fischer, 1892. Rabenborst's Kryptog'fl. I, 4: 37.

Pseudolfielium Fiselier (jro juarte) l.e., p. 33.

Pseudolpidiopsis Minden, 1911. Kryptog'fl. Mark Brandenburg 5: 255.

Thallus intramatrical, appearing more or less naked lont immiscible with the host protoplasm when young hut soon becoming invested with a celluluse wall. Zoosporangia solitary or numerous, up to 50 or more in a lost cell, hyaline or greyish-granular. smooth or covered with non-cellulasic sprines, knohs. or warts; spluerical, oval, ellipsoid, fusiform, clongute, loled, sac-like or irregular with one to several broad, tapering or cylindrical, straight, curved. coiled, short or clongate exit tubes which may end flush with the surface of the host cell or project boyond it. Zoospores lyaline with numerous mimute refractive granules. and in some speeies containing a contractile vacuole; oval, ellipsoid, elongate, and slightly reniform, iso- or heterocont; flagella inserted laterally near the anterior end or anteriorly, shorter flagellum extending linward and the longer me backward in swimming; emerging fully formed and swimming directly away or occasimally lying quiescent in a mass for a few moments at the mouth of the exit tube before beemning actively motile; diplanetic in one species, primary swarmers aflagedlate and amochoid, or flagellate, encysting to form cystospores; movement of zoospores more or le's even in swinning. not darting, interrupted by one to several rest periods during which the flagellin may be retracted. Resting spores parthenogenetic or sexual; spherical, oval, ellipsoid or elongate, hyaline, golden, ycllowish-brown or brown with a smooth or knobly. warty, sping, undulating and 
wary exospore; warts, spines and knobs non-cellulosic; content coarsely granular with one to several large or small refringent globules; male or conpanion cells when present, single or numerous, oval, spherical, elongate or rermiform. hyaline, smooth or warty and spiny. Resting spores transformed directly into zoosporangia in germination and liberating zoospores throngh exit tubes.

\section{General Considerations}

As is shown in the synonomy above species of this genus have undergone the usual taxonomic vicissitudes and have been bandied about from one genus to another. Cornu created the genus Olpidiopsis in 1872 for five parasites which he found in varions species of the Saprolegniales. In three of these parasites he observed thick-walled resting spores to which were attached one or more smaller empty resicles which he assumed to be male cclls or antheridia. Although Cornu did not specifically mention the presence of attaclied cells as the distinguishing generic character of Olpidiopsis, it subsequently came to be regarded as such. Reinsch ('78) later observed the passage of the protoplasm of the small cell into the larger thallus, and since that time the resting spores of Olpidiopsis have been generally believed to arise from fusions of unlike and sexually differentiated thalli. In a subsequent study of these parasites, Fischer (' 80 ) failed to find empty male companion cells attached to what he helieved to be the resting spores of $O$. Saprolegniae. Accordingly, two years later (' 82 ) he rejected the cellule adjacente character as diagnostic for the genus, and rediagnosed and described Olpidiopsis as luaving ascxual resting spores. Further studies in the meantime, however, convinced Fischer that his earlier obscrvations were incorrect, and in 1892 he interpreted the genus in the original sense and cstabHished a second genus. P'seudolpidium for the Olpidiopsis-like species with asexual resting spores. In this genus he included $P$. Saprolegniae and $P$. fusiforme, for which he described resting spores, and four additional doubtful species in which resting spores were unknown.

In the meantime Zopf ('8t) and Fiscll ('8t) liad described two similar parisites, $O$. schenliana and Pleocystidium parasiticum, with uniflagellate zoospores and sexual resting spores in spirogyra. 'Two years later Schroeter established a new genus, $D$ iplophysa, for Cornu's O. Saprolegniae and his own $D$. elliptica which parasitizes Mesocarpus sp. Fischer ('92), however, reduced Diplophysa and Pleocystidium to synonyms of Olpidiopsis and divided Cornu's genus into two subgenera-Olpidiopsis with biflagellate zoospores, and Pleocystidium with uniflagellate zoospores. In the former he placed $O$. Saprolegniae and $O$. minor (O. fusiformis), while $O$. schenkiana and $O$. parasitica were included in Pleocystidium. The sporangia and resting spores of screral additional algal parasites were described by de Wildeman in 1895 , and in 1911 Minden established a new genus Pseudolpidiopsis (symonymous with Pleocystidium and Diplophysa), in the family Olpidiaceae for these species as well as $O$. schenliana and $O$. parasitica. Inasmuch as the number of flagella on the zoospores of de Wildeman's fungi were unknown. Minden was not justified in referring these species to Pseudolpidiopsis. Since that time the zoospores of $O$. schenliana and its synonym $O$. parasitica have been shown to be biflagellate and heterocont, so that Pseudolpidopsis also becomes a symonym of Olpidiopsis. In the meantime, Butler ('07) added two additional species to the genus Pseudolpidium.

Since the time of Fischer and Butler until quite recently very little critical study was made of $P$ seudolpidium, altlough several new Olpidiopsis and Pseudolpidium species were described, and these two genera have been distinguished respectively by the presence and absence of male cells on the resting spores. In 1939, however. McLarty and Shanor independently discovered that the spiny structures which Fischer had interpreted as the resting spores of Pseudolpidium are nothing more than spiny evanescent zoosporangia, thus showing that Fischer's genus, based on the misinterpretation of these sporangia, is no longer valid. McLarty found in addition that the majority of resting spores of $O$. Achlyae develop parthenogenetically without sexual fusion, which suggests further that other Pseudolpidium species, i.e., P. Pythii, P. gracile, and $P$. stellatum, etc., with true resting spores lacking in attached male cells are only parthenogenetic members of Olpidiopsis. He ('41) accordingly amended the diagnosis of Cormu's genus to include such species and listed Pseudolpidium as a synomym. The present writer is following this diagnosis almost completely but retaining $P$ seudolpidium provisionally as a dumping ground for the specics in which no resting spores have yet been found, i.c., $P$. Glenodinianum, $P$. Sphaeritae and $I$. deformans. The first two of these species will probably be included eventually in Olpidiopsis, but $P$. deformans, because of its amoeboid schizogonic thallus, appcars to belong to a different group of organisms.

MeLarty and Shanor furthermore demonstrated quite clearly from monozoospore infection experiments that the number, size and shape of the zoosporangia as well as the character of the spines. warts, and knobs on the resting spores are highly variable and of little diagnostic value in distinguisling closel $y$-similar species. It is accordingly almost impossible to determine with certainty the identity of most of the Saprolegnia- and Achlya-inhabiting species which were only briefly and meagerly described prior to 1939 and 1941 . Until all species have been as intensively studied as $O$. zarians and $O$. Achlyae, an accurate diagnosis of this genus is well-nigh impossible, and for this reason the classification given below is to be regarded as temporary.

Particularly significant in diagnosis are the results of Shanor's ( 40 ) and Miss Whiffen's (" 4 ) 


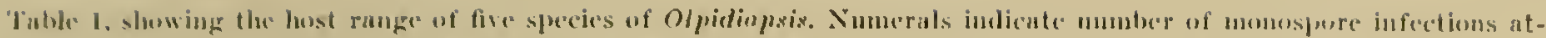

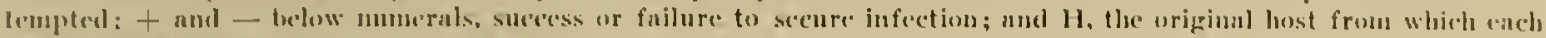
pardste was isulated. Firm shanor, 1910.

\begin{tabular}{|c|c|c|c|c|c|c|c|c|c|c|c|c|c|c|c|c|c|c|c|c|c|c|c|c|c|}
\hline \multirow[b]{2}{*}{ I'arasites } & \multicolumn{25}{|c|}{ Ilosts } \\
\hline & 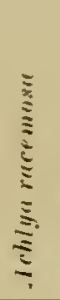 & $\begin{array}{l}\vdots \\
\vdots \\
\vdots \\
\vdots\end{array}$ & 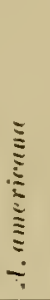 & $\frac{\infty}{\vdots}$ & $\begin{array}{l}\vdots \\
\vdots \\
\vdots \\
\vdots \\
\vdots\end{array}$ & $\begin{array}{l}\Sigma \\
\vdots \\
\vdots \\
\vdots \\
\vdots \\
\vdots \\
\vdots\end{array}$ & 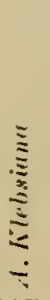 & $\begin{array}{l}\Sigma \\
\vdots \\
\vdots \\
\vdots \\
\vdots\end{array}$ & $\begin{array}{l}\Sigma \\
\vdots \\
\vdots \\
\vdots \\
\vdots\end{array}$ & $\begin{array}{l}\vdots \\
\vdots \\
\vdots \\
\vdots \\
\vdots \\
\vdots\end{array}$ & 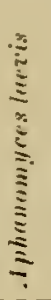 & 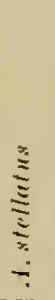 & 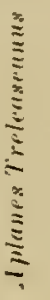 & $\underset{\vdots}{\vdots}$ & 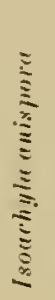 & $\stackrel{\vdots}{\vdots}$ & 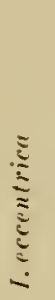 & $\begin{array}{l}\vdots \\
\vdots \\
\vdots \\
\vdots \\
\vdots \\
\vdots \\
\vdots \\
\vdots \\
\vdots\end{array}$ & $\begin{array}{l}\vdots \\
\vdots \\
\vdots \\
\vdots \\
\vdots \\
\vdots \\
\vdots \\
\vdots \\
\vdots \\
\vdots \\
\vdots \\
\vdots \\
\vdots \\
\vdots \\
=\end{array}$ & 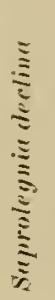 & $\underset{\Xi}{\Xi}$ & $\frac{5}{5}$ & 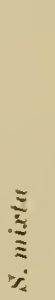 & $\begin{array}{c}\frac{\Xi}{5} \\
\vdots \\
\vdots \\
\vdots \\
\vdots\end{array}$ & \\
\hline iliumiverius & + & + & 3 & $\because$ & H & 8 & 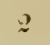 & 2 & $\stackrel{2}{\sim}$ & 2 & 2 & $\stackrel{2}{2}$ & 2 & 2 & $\mathfrak{Z}$ & $\mathcal{2}$ & $\mathcal{I}$ & $\mathfrak{a}$ & $\stackrel{2}{2}$ & $\stackrel{2}{2}$ & 2 & 9 & $\mathcal{g}$ & $\mathfrak{2}$ & 2 \\
\hline & + & + & - & - & + & - & - & 一 & - & - & - & - & - & - & - & - & - & - & -- & - & - & - & - & - & \\
\hline fusiformis & $t$ & + & 3 & 2 & $\tilde{i}$ & HI & 2 & $\boldsymbol{\alpha}$ & 2 & 2 & 2 & 2 & 2 & 2 & 2 & 2 & 2 & 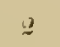 & $\stackrel{2}{2}$ & 2 & 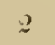 & $\mathfrak{2}$ & 2 & 2 & $\mathscr{g}$ \\
\hline & + & - & - & - & - & + & + & - & - & 一 & - & - & - & - & - & - & - & - & - & - & - & - & - & - & \\
\hline Saproleguier & 2 & 2 & 2 & 2 & 2 & 2 & 2 & $\mathfrak{z}$ & $\mathscr{2}$ & $\mathcal{I}$ & 2 & $\mathfrak{z}$ & 2 & 2 & 1 & + & + & $\stackrel{2}{\sim}$ & 2 & $H$ & 1 & 1 & I & 1 & 2 \\
\hline & - & - & - & - & - & - & - & - & - & - & - & - & - & - & + & + & + & - & - & + & + & + & + & + & \\
\hline nerassula & $\approx$ & 2 & $\mathcal{2}$ & 2 & 2 & 2 & $\mathfrak{z}$ & 2 & 2 & $\stackrel{2}{2}$ & $\mathscr{2}$ & 2 & 2 & 2 & 2 & 3 & + & 2 & $\mathfrak{2}$ & 1 & 1 & $\mathrm{H}$ & 1 & 1 & 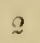 \\
\hline & - & - & - & - & - & - & - & - & - & - & - & - & - & - & + & + & - & - & - & + & + & + & + & + & \\
\hline Inxurians & $?$ & 2 & 2 & 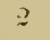 & $\mathscr{2}$ & 2 & 2 & 2 & $\stackrel{2}{2}$ & $\mathfrak{q}$ & $\mathrm{H}$ & 4 & 3 & 2 & 2 & 3 & 2 & 2 & 2 & $\stackrel{2}{2}$ & $\stackrel{2}{2}$ & $\stackrel{2}{\sim}$ & $\stackrel{2}{\sim}$ & 2 & $\stackrel{2}{2}$ \\
\hline (O. I phunomycix) & 一 & - & - & - & - & - & - & - & - & - & + & $\ldots$ & - & - & - & - & - & - & - & - & - & - & - & - & \\
\hline
\end{tabular}

cross inoulation experiments involving numerous host spreeics of Saprolegmia, Achlya, other related genera, and $P$ 'ythium. As is shown in table 1 , Shanor found that $O$. fusiformis and $O$. zarians are restricted in host range to a few species of Achlya, while O. A phanomyecs (O. Iururiaus) is limited to I phanomyces laeris. Miss Whiffen, however, found a form of the latter suecies on d. cladogamous which wonld not infect 1 . laris. Olpidiopsis Saprolegniac and $U$. incrassata, on the other hand, are restricted to the same species of Saprolegnia and to all lut one, $I$. eccentrica, of the same species of Isoachlya, according to Shanor. The number of infections attempted hy Shanor, however, is small, and nore extensive tests may possibly give different results. Furthermore, it is not evident from Shanor's account that temperature, $p H$ concentration, and other cuviromental conditions werc controlled in his experiments. Such factors have proven to be very significant in infection and development of other fungus diseases, and it is quite probable that they "luerate in relation to Olpieliopsis also. Conetheless, the obligate parasitism and limited host range of Olpidiopsis species which parasitize the Saprolegniaceac have licen elearly established. Shanor's results are furthermorc significant, hecause they suggest that species which were formerly believed to be distinct. O. Iphanomyces and O. Iururians for example. may be identical. 'lisis is further sulustantiated by the observations that these speeies are not as distinct morjlologically as they were earlier reported to lie.

"The data presented ly. McI arty" and Shanor show very" definitely that hasty ubervitions and meager descriptions. of the kind so frepuently made in the past, without exact identification of the host and in- tensive study of the range of morphological variation, are practically worthless in the study of $O l_{p i-}$ diopsis. Further studies on these parasites of saprolegniaceous hosts, if they are to be of valne, must comply with the following eriteria: 1. Fxact identification of the host from pure cultures; "2. Monospore infections of a pure eulture of the host to determine whether one or more parasite syecies are present in the original lost culture: 3. Intensive study of monospore infection cultures of the parasite to determine the variations in size, shape, and echinulation or spininess of the sporangia, in the degree of sexuality present, and in the eharacter of the outer resting spore wall; + , Fixtensive inoculation of saprolegniaccous hosts to determine the host range.

\section{Development of 'Thalli and \%oosporangia}

The derelopment and life eycle of Olpidiopsis speeies are as follows: The zoospore comes to rest on the host cell, develops a definite cellulose wall (fig. 8) and forms a conspicuous germ tuhe throngh which the content of the spore piasses into the host (figs. 9-1 I), learing the empty case on the outside. Occasionally, the germ tube fails to penetrate the host and may clongate and hranel to a marked degree. ligure 7 shows a spore which serminated in water outside of the host and formed a linuched germ tube which is strikingly similar to the rhizuidal system of a young rhizidiacous ehytrid thallus. 'I'lue newly-entered zoospores and young tlalli are apparently naked but immiscilyle with the lost protuplasm. Fiven after ten hours following entry into the host Melarty was unable to demonstrate the 
presenee of a structural cellulose wall by plasmolytic experiments and treatment with chloro-iodide of zinc. Aceording to Scherffel and Diehl, the young parasite may ehange its shape and position and independently undergo slight amoeboid movement, but McLarty maintained that in $O$. Achylae, at least, such changes are caused by the rapid streaming of the host protoplasm in which the parasite is passively earried along (figs. 12-15). In $O$. andréei (P. Ectocarpi) $\mathrm{J}_{\mathrm{ok}}$ l figured the young thallus as an amoeba witl one to several long. more or less radially oriented pseudopods (fig. 162) which migrates towards and engulfs the host nucleus. Fiseh and Seherffel also liave shown that the young thalli of $O$. schentiana (I. parasiticum), and O. Oedogoniorum respectively are often to be found in elose association with the host nucleus (fig. 133) which suggests that the food supply may be more optimum in that region of the host cell.

All present-day workers are agreed that no fusion of young thalli or newly-entered zoospores to form a plasmodium occurs in Olpidiopsis. The monospore infection experiments of MeLarty and Shanor show conclusively that each zoospore gives rise to a single independent thallus or sporangium. By the time the thallus has attained mature size it is invested by a definite wall which in most species has been slown to give a marked positive cellulose reaction when tested with ehloro-jodide of zinc. This wall is evidently formed by the parasite itself, but the knobs, warts, and spines which may later appear on it apparently have a different origin. As Fischer has shown, globules and masses of transformed host protoplasm accumulate at separate points around the periphery of the thallus wall (fig. 31) and are gradually transformed further into spines, warts, and other exerescences (fig. 32). These spines show no positive cellulose reaction when tested, which further suggests that they are different from the primary wall. Inasmuch as they are formed in this manner, it is to be expected that they will vary markedly in size, length, and shape. As is shown in figures 26 to 30 they may be lacking entirely or cover only a part of the sporangium (fig. 26) and vary from blunt knobs to broad or fine spines. Spininess of the sporangia can therefore no longer be regarded as a specific character.

The protoplasmic changes which occur during the growth, development, maturation and cleavage of the thalli and zoosporangia have been intensively studied in living as well as fixed material of several Olpidiopsis species, particularly O. Saprolegnia, $O$. A phanomycis, and $O$. Achlyae. Successive stages of these changes are illustrated in figures 16 to 25 of two sporangia of $O$. Achlyae. The young developing thallus usually includes numerous fatty refractive bodies, and as it grows in size, the latter increase in number and size and impart a granular and slightly yellowish gleam or refringent appearance to the protoplasm (fig. 16). With further development these globules gradually become broken np into bodies of smaller size and appear as oily droplets suspended in the more homogeneous protoplasm (fig. 17). At this stage of development small vacuoles appear in the protoplasm (fig. 17), and as they become more distinct they begin to coalesee. The protoplasm at this stage appears granular and slightly brown in appearance, and when stained with Sudan III it becomes briek-brown in color. Coaleseence of the vacuoles continues until one or more large central ones are formed (fig. 19). Within an hour following this stage the racuoles begin to undergo changes in shape (fig. 20) which may continue for a few minutes to half an hour. Cleavage furrows then begin to form at the periphery of the vacuoles and travel centrifugally to the plasma membrane (fig. 21) and delimit the initial zoospore segments (fig. 22). However, in $O$. Achlyae the areas previonsly occupied by the vacuoles as such do not disappear as the cleavage furrows eut through the plasma membrane as Schwartze ('22) described for $O$. Saprolegniae. In-

PLATE 9

$$
\text { Olpidiopsis Achlyue }
$$

(All figures after McLarty, '41)

Fig. 1. Slightly bean-shaped living zoospore with vacuoles and refractive granules.

Fig. 2. Fixed and stained zoospore with large nucleus. Slightly unequal flagella inserted beside a deep-staining body near the anterior end.

Fig. 3. Amoeboid zoospore.

Fig. 4. Zoospore retracting flagella before going into a temporary rest period.

Figs. 5, 6. Zoospore at rest.

Fig. 7. Zoospore germinated in water with a hranched, rhizoid-like germ tube.

Fig. 8. \%oospore at rest and encysted on surface of host hypha.

Figs. 9-11. Successive infection stages.

Figs. 12-15. Changes in shape of the newly-entered parasite due to the streaming of the host protoplasm.

Fig. 16. Two inejpient zoosporangia surrounded hy a dense layer and radiating strands of the host protoplasm.

Figs. 17-20. Successive maturating stages of two zoosporangia.

Figs. 21-25. Cleavage and sporogenesis of lower sporangium shown in previous figures.

Fig. 96. Smooth and partly-spiny zoosporangia.

\section{O. zarians}

Figs. $27-30$. Variations in the character of the sporangium wall. Shanor, '39.

\section{O. fusiformis}

Figs. 31, 32. Formation of spines on zoosporangia. Fischer, 82.

\section{O. vexens}

Figs. 33-37. Suecessive stages in the development of a thallus from fixed and stained material. Nuclear division simultaneous and completely synchronous. Barrett, 12 .

Fig. 38. Portion of a zoosporangium following cleavage. V acuolar areas still present. Barrett, l.c. 
PLA'Tl:9
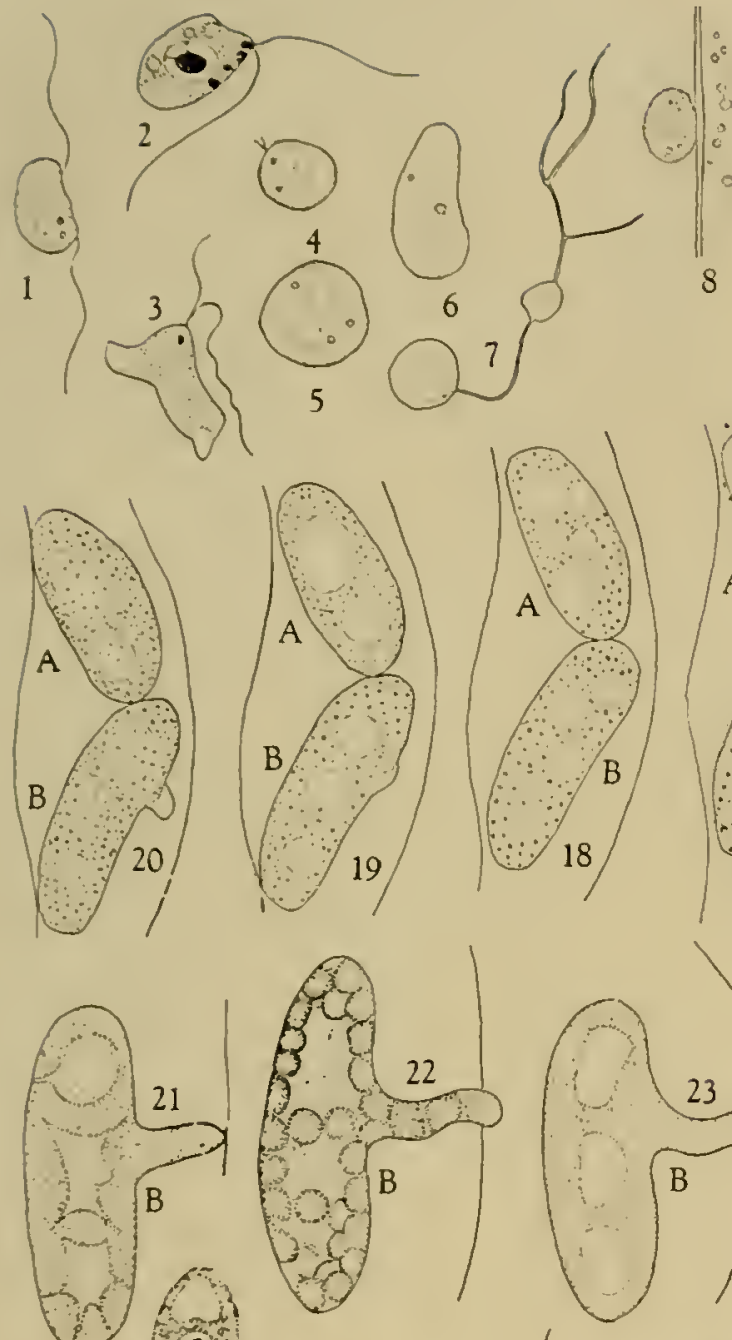

10
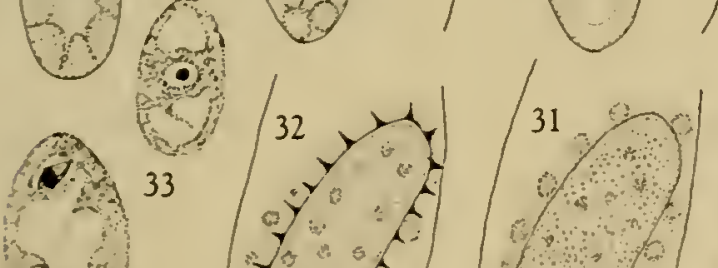

(1)

33

\section{4}

$\therefore-$
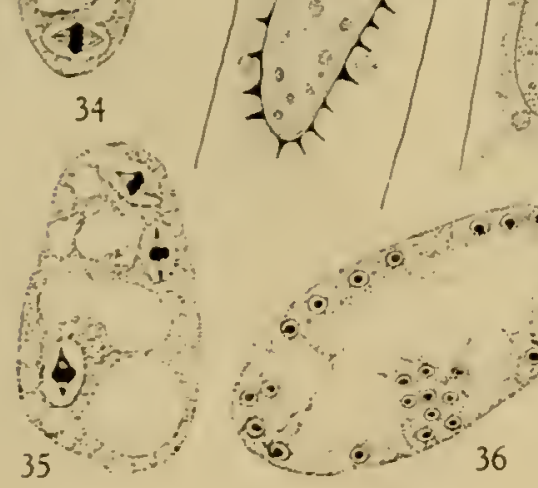

$\left.{ }_{35}^{2}\right)$
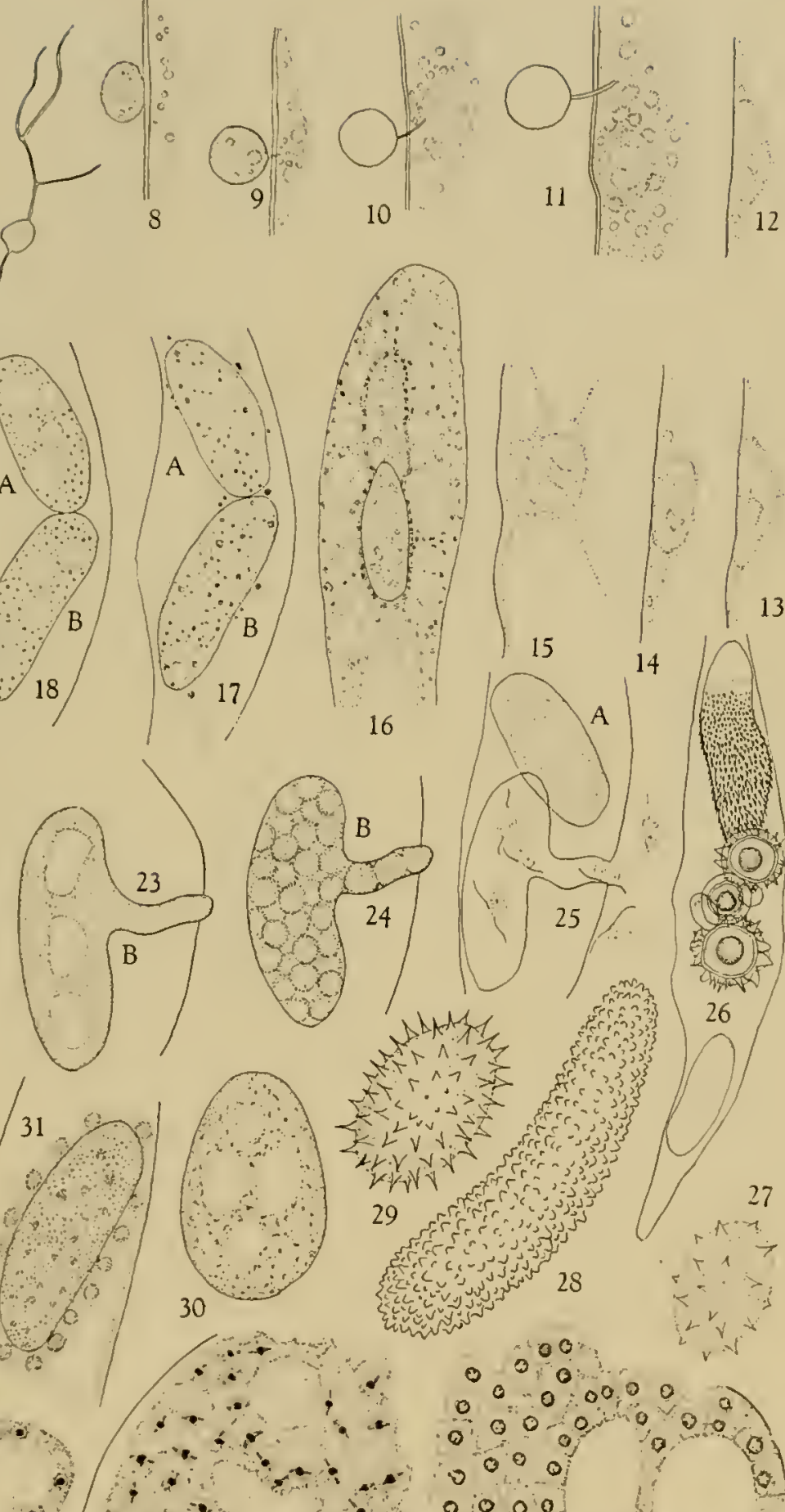

16

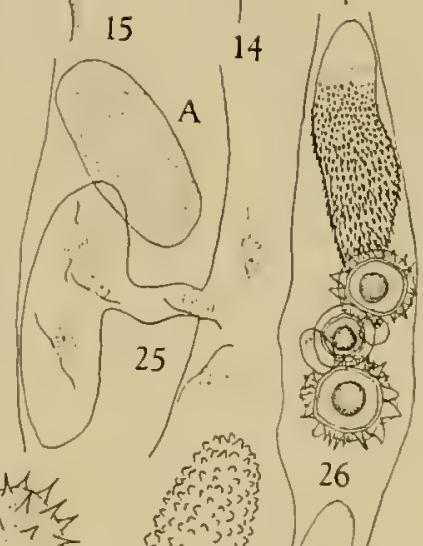

$x_{x \rightarrow 1}+x^{2}=1 / 2$

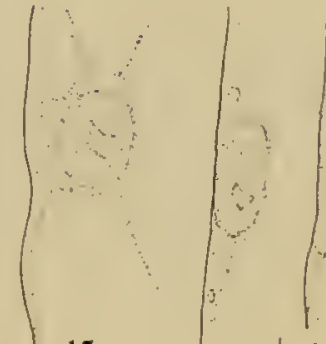

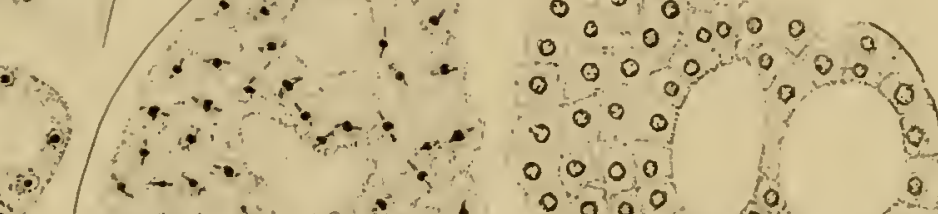

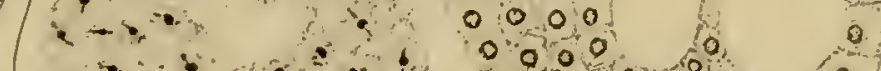


stead, McLarty found that for abont a minute following the completion of cleavage the zoosporcs remained faintly visible flanking the irregular vacuolar spaces (fig. 22). Then as the protoplasm becomes more homogeneously granular and somewliat oleaginous in appearance again, the outlines of the zoospores disappear, and the vacuoles regain their even contours (fig. 23). This is the so-called homogeneous stage following cleavage which has been deseribed by most students of Olpidiopsis. Sporangia in the stage illustrated in figure 23 may undergo a prolonged rest period before liberating the zoospores. That the zoospore initials do not becomc confluent during the homogeneous stage, as Butler ('07) believed, is shown by McLarty's plasmolytic experiments on sporangia in this stage. After a period of about threc quarters of an hour the zoospore segments become visible again (fig. 24), and shortly thereafter the vacuolate areas disappear suddenly and entirely. The zoospores soon assume their mature sliape and begin to swarm in the sporangium, and within a few minutes following this stage, the tip of the exit tube opens. The zoospores then emerge fully developed and swim directly away (fig. 25).

$V$ ariations of the type of clcavage and zoospore behavior described above for $O$. Achlyae have often been reported. In $O$. Saprolegniae and $O$. Oedogoniorum, for example, Coker ('23) and Scherffel ('25) noted that the whole content of the zoosporangium may occasionally emerge to the outside as a globular, naked, undifferentiatcd, protoplasmic mass and then undergo cleavage into zoospores as in Lagenidium and Pythium. In $O$. Pythii the zoospores swarm for a brief period at the mouth of the exit tube (fig. 114) and then come to rest in a cluster, according to Butler. After a few minutes motion is resumed, and the zoospores, which are by this time provided with two flagella, swim away. A similar behavior for the zoospores of $O$. schenkiana was reported by Scherffel (figs. 137, 138). This initial rest period at the mouth of the cxit tubc and the subsequent ones which interrupt the active swimming stage have been interpreted by Butler. Barrett, Scherffel, and DiehI as evidence of primitive or rudimentary diplanetism. In coming to rest the zoospores may retract their flagella (fig. t) and assume spherical or elongate shapes (figs. 5, 6) but they do not encyst. At least no empty vesicle is left behind as they form new flagella and swim away. In $O$. Oedogoniorum, on the other hand, Scherffel reported true diplanetisn. The primary swarmers are laterally bitlagellate (fig. 153). The cystospores later germinate, and an empty vesicle is left behind as the secondary swarmer emerges. Whether or not the position of the flagella on the secondary swarmers differs from that of the primary swamers is not known.

The accounts and descriptions in the literature on the shape of the zoospores and relative lengths of the flagella vary considerably. Most investigators have described the zoospores as oval, elongate, and tapering at the anterior end or some what reniform with- out a marked ventral furrow and with two flagella of equal or almost equal length inserted in or near the anterior end. Other workers have reported them to he almost spherical, oval, pyriform and distinctly heterocont (figs. 103, 158). Accuratc data on the exact location and relative lengths of the flagella are lacking in most species. However, since the zoospores swim fairly rapidly and undergo changes in shape it is difficult to determine with certainty the relative lengths of the flagella in living material. Markedly heterocont zoospores have been reported and figured for $O$. irregularis (Coustantineanu, '01), O. schenliana (Scherffel, '25), and O. Ricciae (du Plessis, '33), while in the remaining species they have been described as isocont or with flagella of

\section{PLATE 10}

\section{O. Achlyae}

Figs. 39-53. Successive stages of nuclear division. McLatrty, l.c.

\section{O. huxuriuns}

Fig. 54. Two young incipient zoosporangia and a larger female thallus with an attached male thallus in a swollen lyphal tip. Barrett, l.c.

\section{O. Achlyae. \\ (All drawings after Mclarty, l.c.)}

Figs. 55-58. Successive stages in the development of a parthenogenctic and a sexual spore. Incipient spores in figure 55 surrounded by a lyaline, amorphous zone or layer.

Fig. 59. Incipient spore from fixed and stained material showing centripetal development of spines at localized points.

Fig. 60. Remanent of border of anorj]lous yone forming a membrane-like border around the tips of the spines.

Figs. 61-67. Variations in the character of the exospore.

\section{O. rexreus and other species}

Fig. 68. Young male and female thalli; nuclei dividing. Barrett, l.c.

Figs. 69-76. Stages in nuclear division from female thallus. Barrett, 1.c.

Fig. 77. Gelatinization of intervening wall between the male and female thalli prior to plasmogamy. Barrett, l.c.

Fig. 78. 1 ater state in gelatinization. Nuelei in small male thallus dividing. Barrett, l.c.

Fig. 79. Passage of male nuclei into female thallus. $O$. Iuxurians. Barrett, l.c.

Figs. 80-8?. Nuclear pairing and karyogamy. $O$. texutus. Barrett, l.c.

Fig. 83. Mature resting spore with two attached male thalli which still contain their protoplasm. O. Achlyre. McLarty, l.c.

Fig. 81. Resting spore with four attached empty male cells.

Fig. 85. One empty male thallus between two resting spores. O. luxuriaus. Barrett, l.c. Drawn trom photograjh.

Fig. 86. Small $O$. minor-like resting spore of $O$. z'arians. Shanor, '39a.

Fig. 87. Early germination stage. Male thallus enveloped by spiny exposure. O. vorians. Shanor, l.c. 
PIATEL 10
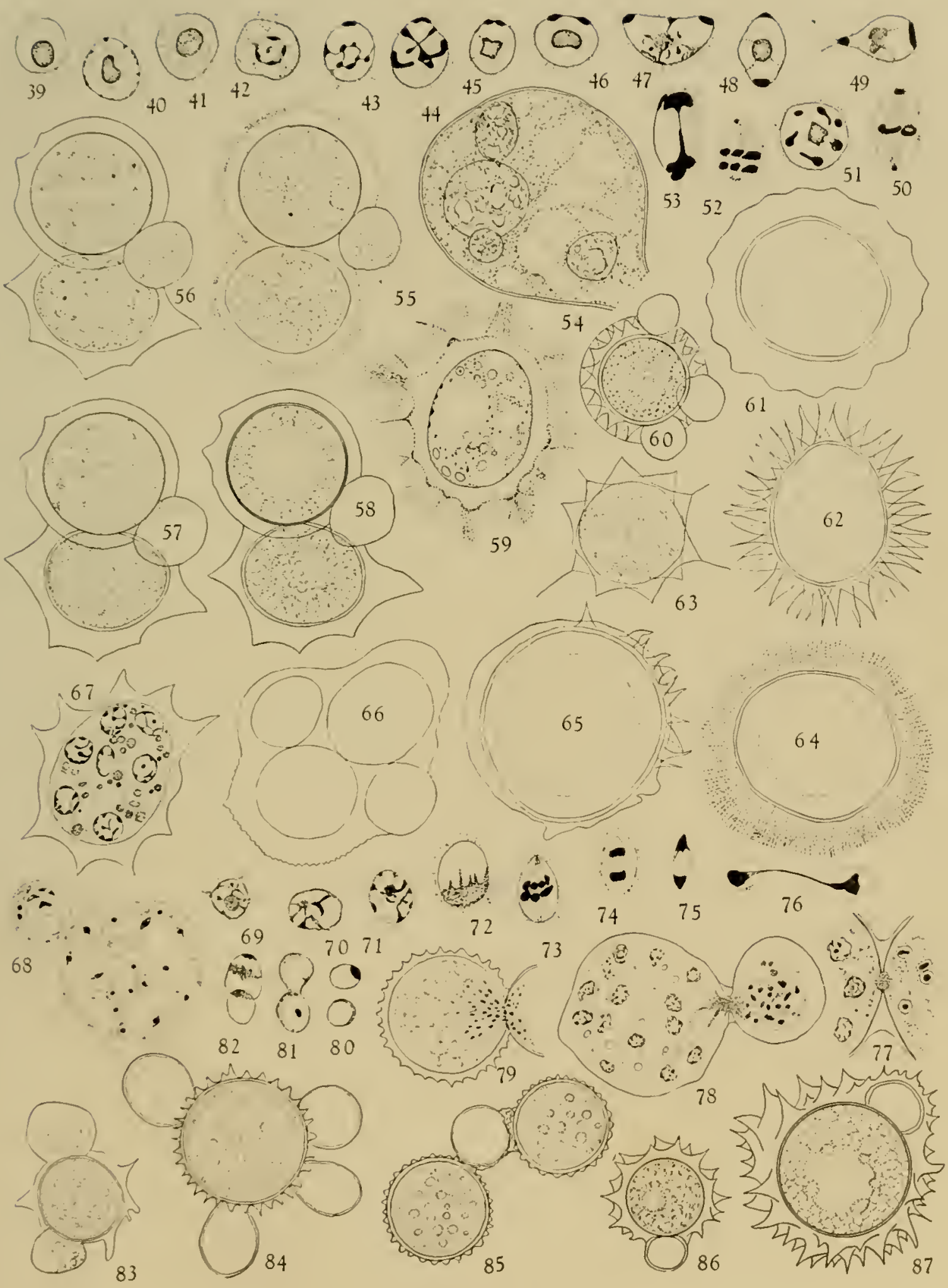

Olpidiopenis 
"ahout" equal length. Whether or not the heteroeont speeies should be segregated in a separate group on this basis is of questionable diagnostie value until the zoospores of all speeies have been intensively studied. Aeeording to Couch (' $\$ 1$ ) one of the flagella of O. Sa prolegniae has a long distinet tail pieee, while the other one possesses nine to eighteen lateral "tinsel" cilia, $1.5 \mu$ long, which may oceur on one or botlı sides or follow a spiral eourse. The same type of flagella will probably be found to oceur in all speeies of Olpidiopsis.

During growth and derelopment of the thalli the nuclei undergo simultaneous and synchronous division (figs. 34, 35, 37), aecording to Barrett and McLarty. Nuelear division is typieally indireet and not of the so-called promitotie type reported for the Plasmodiophorales, although the resting nuelei possess a very large nueleole and little ehromatin in the form of granules on a retieulum (fig. 39). Successive division stages from thalli of $O$. Achlyae are shown in figures 39 to 53 . The faet that most of the stainable material is in the form of a globular nueleole which of ten appears to be vacuolate or made up of differentially stainalule regions (figs. $+1,+2$ ) suggested to McLarty that the nucleole functions as a storehouse of elromatin. This is further substantiated, in his opinion, by the radial orientation of the chromatin network on the nueleole (figs. 40,41 ) and the latter's gradual disappearanee as the prophase ehanges progress. Barrett, on the other hand, found a well-defined dense ehromatin retieulum in addition to a large mueleole in resting nuelei of the female thalli (figs. 58 to 60 ). MeLarty interpreted the emergence of radially oriented eliromatin threads as the beginning of the prophases (figs. 40,41), and as these stages progress the eliromatin becomes more evident as glohular (fig. 43) or rod-shaped densely stained bodies (fig. 4.4). By this time the nucleole has usually disappeared. Coneurrent with the emergence of ehromosomes a deeply stainable eentrosome-like body appears at one of the nuelear poles in $O$. Achlyae (fig. 43) and undergoes division (figs. $45,46)$. The daughter bodies thus formed then gradually migrate around the nuelear membrane (fig. 47) to the opposite poles of the nueleus (figs. $48,49,50)$. Barrett, however, found no evidence of eentrosomes in $O$. verans. No conspieuous astral rays have been found in assoeiation with these bodies in $O$. Achlyae, nor does the division spindle appear to arise from them as far as is now known. Aecording to Barrett, the latter originates from the ehromatin mass in the equator of the nueleus and gradually grows towards the poles, hut his figures of the proeess are not definite and elear. In protile views of the equatorial plate stages the chromosomes are often arranged in a broken ring (fig. 50) around the margin of the spindle, but usually they are closely crowded together and appear as a dark hand. In polar views of this stage (fig. 51) MeLarty found six chromosomes in $O$. Achlyae which is the same number reported by Barrett for $O$. vexans. No evidenee of meiosis has been found in these divisions in the thalli and zoosporangia. The hatres of the ehromosomes separate in the metaphases and migrate (fig. 52) to the poles as two eompact deeply stained masses (fig. 53), which may often be conneeted by a slender ehromatin filament (figs. 53.76). The nueleus and spindle elongate considerably in the late prophases and metaphases, and by the time of the late anaphases the nuelear membrane has usually disappeared entirely. The formation of the daughter nuclear membranes and the telophasie reeonstruction stages of the nuelei are not well known, although figure 76 suggests that the daughter ehromosome groups become surrounded by clear spaces, the boundaries of which later beeme the nuelear membranes. Nuelcar division in the so-ealled antheridia and oogonia is also mitotie (figs. 68 to 76 ). In $O$. rexans, however, Barrett found prophase stages in whieh the chromatin was aggregated in synapticlike masses at one side of the nueleus (fig. 72 ), but he did not believe that they relate to prophases of meiosis.

\section{Resting Spore Development and Sex Differentiation}

As has been noted in the generic diagnosis above the resting spores of Olpidiopsis may develop parthenogenetieally without sexual fusion or as the result of fusion of a large female thallus with one to several smaller male thalli. Some speeies, i.e., $O$. gracile and $O$. $P$, thii, appear at present to be wholly parthenogenetic, while others are only partially so or entirely sexual. The small male and larger female thalli are generally referred to in the literature as antheridia and oogonia, respectively, and the fusion of these eells has been regarded as a primitive or rudimentary type of heterogamous and oomyeetous sexual reproduction. Petersen and Seherffel regarded the resting spores of Olpidiopsis as an oospore in an oogonium which lacks periplasm, and on these grounds the latter worker in partieular postulated the origin of a Pythium-Peronosporaceae series from simple speeies through Olpidiopsis. Use of the terms antheridia and oogonia for the male and female thalli respectively in this genus is obviously. open to serious question sinee these terms in their proper sense relate to gametangia whieh prodnee more or less differentiated gametes. Furthermore, in some speeies, i.e., $O$. andréei, the thalli which fuse may he equal in size, so that sexual reproduetion is oceasionally isogamous. Nevertheless, the development and evolution of antheridia and oogonia and the oonyeetous type of scxual reproduction is elearly foreshadowed in Olpidiopsis. In the diseussion whieh follows the non-committal terms male and female will be used for the thalli whieh fuse.

In the early developmental stages in living material, the female thalli are identieal in appearanee to those which are to develop into zoosporangia, and it is not until they have attained eonsiderable size 
that llaey can le dintinguishad. All thalli therefore alpe:ar to lo potential zoosporangia amel male or female thalli in the carly developmental stages. This is strongly sugresteded hy Maturizios figure 7 of $O$. major which shows two make thalli attached to a larger female thallus with an aborted exit tube. 'Tlue male thalli are indistinguishahle froun small young zousporangia also except for the ir close association with tle female tlalli (fig. 5 - $t$ ). In fixed and stained material. on the other hand, tle female thilli can he recognized quite elearly ly their staining reaction. Barrett found that they hive a marked attinity for Orange C. while the zoosporangia and male thalli readily take up aentian violet. MeLarty likewise noted that the female thalli may he distinguished in the young stages by mumeroms fatty bodies which stain brilliantly with erystal violet.

sucessive developmental stages of a parthemogenetic and a sexual resting spore are slown in figures 5.5 to 58 . In lotll of the incipient spores are numerous large refractive fatty globules, which later appear to decrease in size but inerease in number. The endospore in well developed in figures is and 56 , but in figure $5: 3$ there is yet no evidence of the exospore. Instead, the incipient spores are surrounded by livaline or sliglitly amber-colored zones. The formation of the exospore usually first becomes evident as a homogeneous, amorphous layer which develops centripetally around the spores and gradually replaces the closely surrounding grauular liost protoplasm shown in figure 5.. It is in this layer or zone apparently that the host protoplasm is transformed into spones. warts. knols. or a smooth undulating laver. In $O$. Pythii (figs. 118-1:0) Butler reported that the host protoplasm condenses centripetally, so that at one period the onter ends of the spines appear sharp and fully formed while the proximal part is still enveloped in lost protoplasm. "The investing band of protoplasm described ly Butler is probably a zone in which the host protoplasm is heing transformed and deposited as spines. A resting spore of $O$. Achlyar in the process of exospore formation from fixed and stained material is shown in figure 59. The condensation or deposition appears to be occurring along radially oriented lines, and in certain regions the lines are localized and organizcel into conical groups or hundles. which apjarently represent incipient spines. It is to be further noted that the lines do not cxtend all the way in. but are progressing from the outer margin towird the center. 'That the layer or zonc shown in figure 5.5 is not merely a region filled with cell sap may he demonstrated by microdisseetion. MeI arty found hy such studies tlat this zone is a comparatively tough structural layer. After the spines liave been fully formed the houndary of this layer may often persist as a thin memliranc-like structure (figs. j6, (io) a rund the tips of the spines, which gives the impression that the resting spore lices in an cmpty hyaline vesicle. McI arty found tluat the exospore may be poorly developed in resting spores whiclı use up most of the host protoplasm in the early derelopmental stages, and suggested tliat the extrnt of exospore formation, i.e.. length, thickness, and abumdance of spones, warts, knolus, coten is dependent on the amount of host protoplasm present at the time of its development. In that event, it will olvionsly vary to a higle degree and is not to he resiarded is a stable: diagnostic claracter. Furtherinore, the exospore composed of spunes, wirts, knols, or a smooth undulating layer does not vive a positive collulose reaction when tested with chloro-iodicle of zinc.

As noted above, the cxospore may exhibit marked variations in a single species. In $O$. Achlyar it may le smooth, even, or undulating in contour (figs. 56. 61, 65, 66) as in O. incrassata; composed of fine. thread-like spines (fig. 6 t) as in O. fil rillosa; loroad triangular spines, as in 0. minor (figs. 60, 63, 67) ; long tapering curved spines (fig. (62) as in $O$. curroispinosa; or partly smooth and spiny (fig. 6.5). Occasionally. two resting spores and two male cells may be enveloped by one exospore (fig. 66). l'arthenogenetic spores may vary in cxospore structure to the same degree as the sexual spores in $O$. Achlyar. Similar but less extensive variations have been described by Shanor ('39a) for O. rarians, and an examination of figures 91 to 111 shows how variable the earlier known species of Olpidiopsis also are. The empty male thalli or companion cells likewise may be smooth, eclinulate, warty or spiny. Obviously, a character as variahle as the exospore is of little diagnostic value in distinguishing species.

Returning to the deseription of plasmogamy and karyogamy, it is to he noted that the male and female thalli are multimucleate hefore they show any marked visible differentiation as gametes, except for relative size. Their nuclei may continue to divide mitotically (figs. 68-76) up to and even during (fig. 78) the initial stages of plasmogamy as has been shown by Barrett and McLarty. The first step in plasmogany in species in which it vecurs through a pore, according to Barrett, is a swelling and gelatinization of a portion of the intervening wall between the fusing thalli (fig. 77). In fixed and stained material this region is usually heavily stained. A more advanced stage of gelatinization is shown in figure 78 where the cell wall material appears to be diffusing into the two thalli. The nuclei in the male thallus are dividing while those in the female are at rest, hut it is not uncommon to find them dividing in both gametes during plasmogamy. After the so-called fertilization pore las becin formed the protoplasm of the male thallus begins to flow into the female (figs, 57,79 ). The passage ma he eompleted within a few minutes or last severisl hours. Following plasmogamy, the fused protoplasts change in their susceptihility to stains and have a greater aftinity for safranin. aceording to Barrett. The gametic nuclei become irregularly distributed in gromps and decreasc considerably in size. At the same time the number of refractive oil globules increases. and the fertilization pore eloses. During these processes the exospore undergoes differentiation, as described abore, and attains its definitive 
character. There are no size differenees between the male and female nuclei, so that it is impossible to distinguish them on this basis, according to Barrett and MeLarty. Both of these workers found nuclei in pairs, and Barrett figured a few stages of what he believed to be nuclear fusion (figs. 80-82). Although he did not find conclusive evidence of nuclear fusions in pairs, he nonetheless believed it oecurs. MeLarty, on the other hand, failed to observe fusion and held that the oceasional occurrences of nuclei in pairs may be merely fortuitous. Therefore, the problem of the type of karyogamy, i.e., whether the numerous gametic nnclei fuse in pairs or all but one pair degenerate, in Olpidiopsis still remains to be solved. That plasmogamy of male and female thalli is not always essential to resting spore development is evident in the species which are partly or wholly parthenogenetic. In $O$. Achlyae, McLarty observed cases in which only part of the male protoplast passed into the female thallus. Oceasionally one male may "serve" two female thalli, and in some instances as many as two to eight empty malc thalli have been found attached to a single resting spore. Apparently in these instances there are supernumerary wale nuclei following plasmogamy, but whether or not the unmated ones degenerate is not known. Obvionsly, sexual reproduction in Olpidiopsis presents numerous unsolved cytological problems. and until these have been solved it will be impossible to determine how closely Olpidiopsis is related to the higher Oomycetes.

It is also probable that male thalli are capable of developing androgenetically into resting spores. At least this is suggested by the small spore shown in figure 108. In some species the male thallus is attached to the female hy an attenuated neck or canal (figs. 143, 114, 149, 150, 156), through which the male protoplast passes during plasmogamy. As in other organisms this neck is generally referred to as a conjugation or fertilization canal. Sometimes the male thalli may occur in tandem (fig. 149) but whether or not the content of the terminal one passes through the adjacent companion cells to reach the female in such cases is not known.

\section{Sex Determination}

It has been generilly assumed by most mycologists that species of Olpidiopsis are heterothallic, inasmuch as the resting spores are formed nsually by fusion of thalli of unequal size. However, the monospore culture experiments of McLarty and Shanor on $O$. Achlyae and $O$, varians have discredited this belief, and it now seems that most, if not all, Olpidiopsis species are homothallic or haplosynoecions as was earlier suggested by the author ('39) and McLarty ('39b). As noted elsewhere MeLarty and Slanor found that sexually formed resting spores may occur readily in cultures propagated from a single zoospore. Similar results will probably he sccured from other species when they have been studied in monospore cultures. In light of what is known to oecur in haplonts. meiosis probably occurs during the first division of the diploid (?) nuclei in the germinating resting spore. but whether or not sex is genotypically differentiated at this stage is not alssolutely certain inasmuch as McLarty and Shanor did not make monozoospore eultures from germinating resting spores. However, the fact that a single zoospore from a sporangium will give rise to cultures which later form male and female thalli shows that it carries the potentialities of both sexes. If sex is genotypically determined at meiosis in the germinating resting spore the resultant zoospores would be male and female in equal numbers and develop into sporangia of opposite sexes, which is eontrary to the results obtiined by McLarty and Slanor. According to their data sex in Olpidiopsis appears to be determined phenotypically at some stage in the haploid generation. Olpidiopsis Achlyae and $O$. varians accordingly seem to be haplosynoecious. At which stage in the life cycle sex differentiation occurs is not known. As las been pointed out above ineipient zoosporangia as well as the male and female thalli are multinueleate and quite similar in appearance, and until differentiation occurs it is impossible to tell which type of reproduetive strueture is going to develop from them. It seems that all thalli in the early stages are potential male and female cells which under certain external environmental and internal conditions become differentiated and develop into gametes.

\section{Cellular Relations Between Host and Parasite}

As has been noted elsewhere, all species of this genus appear at present to be obligate parasites with a limited host range. So far they liave not been successfully grown on synthetic media, although Diehl ('35) was able to bring zoosporangia to maturity on agar. According to his observations, the maturation stages of zoosporangia are not dependent on the presenee of the host. All Olpidiopsis species which parasitize members of the Saprolegniales and Pythium usually cause marked local hypertrophy of the infected hyphae but do not induce septation except in the case of Pythinm. In the latter host the supporting hyphae may occasionally be delimited from the remainder of the mycelium by cross walls (figs. 112,113). The swellings in the lost lyphae may vary markedly in shape and size, and nay be terminal, interealary, or in some cases project out as lateral diverticula. Most species which parasitize algae cause little or no hypertrophy, but $O$. zopfii and $O$. appendiculata may induce local swellings which are two to four times the normal diameter of the algal filaments. Infection by $O$. Oedognoriorum leads to the formation of a conspicuous phug of cellulose loy the host cell (fig. 131) at the point of entry of the germ tubes.

In cases of infection by $O$. Achlyae, the penetration of the germ tube and entrance of the parasite 
may tanse a locialized temporary agitation of the

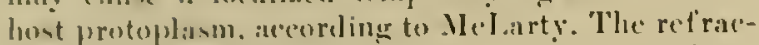
tive erramles in the latter swirl in cethe's armmel the young baravito (tig. 10) and soon olssure it from view, l'his reation. however. is of short eluration,

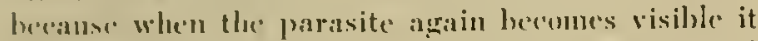
is elosely surrounded hy the loost protoplism and larelly divtinguishalole" from orelinary protoplasmic inclusions. "The two protoplasts apperar to be intimately assoeiated, and no visilule antagunism is exhibited. It least. there is no retraction of the loost protoplasm awy from the parasite. The lost unelei appear normal in its immedinte vicinity and ippurcontly are not stimulated to alivide hy its presence. In O. schenliana (fig. 133). O. Oedogoniorum, and $O$. andreci (tig. 1 (i: ) as noted hefore, the young parasite micrates toward and hecomes closely applied to the host nueleus, and in the case of $O$. andrepi ( $P$. Ectocarpii) may completely engulf it.

As the thalli increase in size the free floit ing phase cuds and the parisites leeome more or less localized in the hyphate. At this stage the host protoplasm herins to flow towarl and accumulates around the thalli. and in a short time hypertrophy of the lost lecrins. In some instances the swelling appears to be initiated in the immetiate vicinity of the parasite, lout this is not the geveral rule. Furthermore, hypertroploy does not invarialoly occur. In some oogonia and liyplace containing limited amounts of protoplasm MrIarty found little or no distortion following infection lis $O$. Achlyar. Aceordingly, he belicred that the swellings are not due to direct stimulation by the parasite but to the great aceumulation of tlec iost protoplasm in its immediate vicinity. 'That the hust wall is stretched in such regions has heen demonstrated hy I)ichl's ('3.5) plasmolytic experiments.

As the swellings increase in size conspieuous vacuoles appear in the host protoplasm (figs. J. 5 t). These soou beeome traversed hy more or less radiating strands of protoplasm moving slowly towards the parasite. 'This novement continues until all or most of the protoplasm has been attracted to and absorbed hy the developing thalli. In the species which parasitim green algae the plastids and muclei are destroyed, and at maturity the sporangia (fig. 1.46) and resting spores are partly surrounded hy a mass of degenerated protoplasm. In O. Ricciae on Riccia, however, no harmful effects are apparent, according to du plessis. This species occurs only in the rhizoids and hasal swelling of the same, and although they hecome infected when young they develop normally. So distortion, swelling, rupture or necrotic effects are produced, and du Plessis aeeurdingly believel that the relationship between host and fungus may possibly he syoubiotic.

\section{PARASI'TESOF SAPROHEGNA}

O. SAPROLEGNIAE (Brauu) Corut, l.c., 1. 1 li, l’t. :3, figs. 1-10.

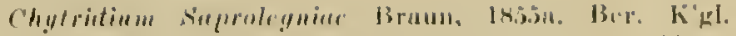

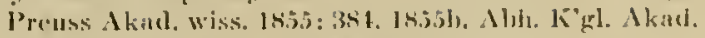

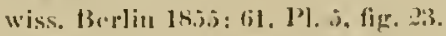

Oppidium Suprolegniere Braun, I.c., p. 7...

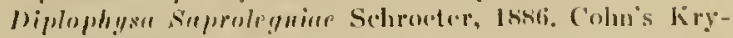
pit'1l. Sichlesicus $3: 19.5$.

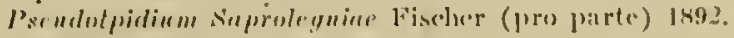
Rahoulloorst's kryjt"t]. I, h: 3.5.

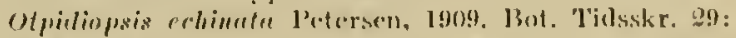

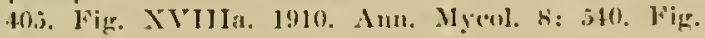
Xilla.

Zoosporangia usually numerous in a host eell. hyaline, smooth or spring (?), varialsle in size and

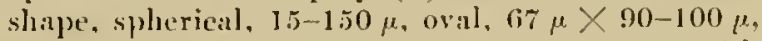
cllipsoid and elongate $15-25 \mu \times 20-150 \mu$, with one to several short or elongate, straight, curved, or irregular exit tubes which end flush with the surface of the host cell or extend consideralyly beyond it. Zoospores isoeont (?). ovil. or slightly liean-shaped with the flacella attached near the anterior end. Resting spores parthonogenetic (?) or sexual, hrown, oval spherical. $28-107 \mu$; endospore thick, exosprore covered witl mmerous slort (?) spines; eompanion or male cells when present 1 to f per resting spore, hyaline, smooth, oval, spherical, 18$32 \mu$; germination unknuwn.

Parasitie in Saprolegnia s].. S. ferax, S. thurcti, and S. mixta in Germany [Nageli, 'f.t (?) ; Briun, 55a, '55b; Pringshein, 60 : Reinsch, '78 (?): Behla, '03; Minten, '11; Diell, '35]; Saprolegnia sp., in Franee [Cornu, l.e.; Dangeard, '90; Varitchak, '31 (?)]. Russia (Sorokin, '83, '89), Roumania (Constantineanu, '01); $S$. dioica and $S$. monoica in Denmark (Petersen, '09, '10) ; S. thureti, S. diclina, S. delica, S. mixta, S. littoralis, S. momoica, Saprolegnia sp.. Isoachlya anisospora, I. unispora, and 1 . eccentrica in the U. S. A. (Barrett. '12: Davis, '1. : Selwarze, '22; Harvey, '27, '22; Graff, '28; Manceal, '37; Shanor, '10; Couch, ' 41 ; Wolf. H); S. thureti and S. monilifera in Japan (Tokunaga, '33) causing large terminal and intercalary swellings in the lost hyphae.

According to Shanor, this species is limited in host range to species of Saprolegnia and Isoachlya and will not infect Achlya, Iphanomyces, Aplanes, Dictyuchns, Leptolegnia and Protoachlya species. If this is true, the parasites deseribed by l'etersen ('09, '10), Coker ('23). Gilman and Areher ('29) and Sparrow ('32. 333) as O. Saprolegniae in . Achlya rolite to inother species, unless these workers werc mistaken ahout the jelentity of the host plants. Sparrow ('33) was of the opinion that Coker's fungrus is O. luxurians, but this seems nulikely since the latter species is contined to I phanomyces hosts, according to Sibnor ( $F 0$ ). Inasmuch as Coker interpreted $O$. Saprolegniae in the sense of lischer (' 922$)$. it is not improbialele that the sjecies which he observed in .1. flagellata and A. imperfecta miny pos silly he $O$. fusiformis or $O$. z'arians. In riew of the fact that sporangium size and shape and the "haracter of the exospore are: no longer diagnostically" specifice and in the light of Shaner's contentions that the species are restricted to certain hosts, it is 
obviously impossible to determine which of the parasites described in the older literature relate to $O$. Saprolegniae.

Olpidiopsis Saprolegniae Cornu is the type species of the genus and probably the parasite which Pringsheim mistook for a developmental stage of Saprolegnia. Cornu limited the name $O$. Saprolegniae to Saprolegnia-inhabiting parasites the resting spores of which are eovered with numerous fine spines, hut Fischer ('92) included Cornu's speeies in Pseudolpidium and restrieted the name $O$. Saprolegniae to a species with hemispherical or blunt, hyaline, up to $3 \mu$ high, warts or pegs on the resting spores. Barrett interpreted $O$. Saprolegniae in the original sense of Cornu and created a new speeies, $O$. vexans, for the parasite with warty resting spores described by Fiseher. Diehl and Shanor supported Barrett's interpretation. but Coker and Graff accepted Fischer's distinction. The present writer is following Barrett's interpretation of $O$. Saprolegniae to a certain degree bnt only temporarily until all species have been more critically studied. Olpidiopsis Saprolegniae Fischer and $O$. vexans Barrett are accordingly reduced to synonyms of $O$. incrassata. However, this does not completely solve the taxonomic problems involved nor greatly aid beginners in recognizing and distinguishing Olpidiops is species. In the first place, $O$. incrassata, for instance, is snpposedly eharacterized by resting spores with a wary undulating exospore, and the introduction under this name of synonymous species. $O$. Saprolegniae Fischer and $\dot{O}$. vexans, with warty or knobby resting spores destroys this distinction. On the other hand. McLarty (' 1 ) has clearly shown that $O$. Achlyae also may form resting spores with a way undulating exospore (figs. 58, 61, 66), which obviously indicates that this character is not speeific for $O$. incrassata alone. Furthermore, O. Saprolegniae Cornu, aceording to Shanor ( $\$ 0$ ), is limited to the same Saprolegnia and Isoachlya hosts as O. incrassata, with the cxception of $I$. eccentrica. Therefore, on the basis of host relationship there is no distinction between these two species. In riew of the fact that sporangium size and slape, number and lengtl of exit tubes, and the character of the exospore no longer appear to be constant for a species, and in the event that Shanor's bost range results are confirmed, it nay perhaps be taxonomically expedient to lnmp all reported Saprolegnia parasites, with the possible exception of $O$. irregularis, under the name of $O$. Saprolegniae Cormu. In that event, Cormn's species would have the following synonomy:

Chytridium Saproleguiur 13raun, l.c.

Olpidium Saprolegnine 13raun, l.c.

Olpidiopsis incressuta Cornu, l.c., p. 146.

O. Suproleguine Fischer, l.c.

O. mujor Maurino, 1895. Jabresber. Nat. Ges. Gräubunclens $38: 15$.

O. echinutu Petersen, l.e.

O. zeauns: Barrett, 1912. Ann. 13vt. 26: 231.

Diplopluyse Saprolegmiar Sehrueter, l.c.

Pscudulpidinu Suprolegniue Fiselar, l.e.

P. incrussutum Fischer, l.c.
Snch a elassification is based entirely on host relationship, which is often a questionable eriterion of distinction. Fevertheless, the author is inclined to agree at present with Petersen's view that $O$. Saprolegniae and $O$. incrassata may possibly be identical. The results of Shanor's cross inoculation experiments appear to be fairly conclusive, hut the number of monospore infections which he made is quite small. It is not altogether improbable that more ex-

\section{PLATE II}

Figs. 88 to 90 . Germinated resting spore and zoospores of $O$. vorions. Exit tuhe passing through empty malc thallus. Shanor, l.c.

Figs. 91 to 93. Echinulate, knobby and spiny resting spore's of $O$. Suprolegniue. Cornu, '72; Petersen, 09 , '10; and Shanor, ' $39 \mathrm{~b}$, respectively.

Fig. 94. Resting spore of $O$. echinatı. Petersen, "09, `10.

Figs. 95 to 97 . Smootl resting spores with attached nale thalli of $O$. Saprolegnice var. laezis. Coker, '23.

Fig. 98. Three parthenogenetic and one sexual resting spore of $O$. incrussuta with broad undtuating exospores. Cornu, l.c.

Fig. 99. Greatly enlarged resting spore of $O$. major with three male thalli, Nlaurizio, 95 .

Figs. 100, 101. Echinulate and knobby resting spores of O. rexalls. Barrett, l.c., and Shanor, $39 \mathrm{~b}$, respectively.

Figs. 102, 103. Irregular lobed zoosporangium and heterocont zoospores of $O$. irregularis. Constantineanu, 01.

Fig. 104. Fusiform zoosporangia of $O$. fusiformis. Petersen, '09, '10.

Fig. 105. Broad-spjined resting spore of $O$. fusiformis. Cornu, l.c.

Fig. 106. Similar resting spore of 0 . minor. Sparrow, $3 \%$.

Fjg. 107. Resting spore of $O$. iudex with echinulate male cell. Cornu, l.c.

Fig. 108. Large and small resting spore of $O$. fusiformis (?). Small spore may possihly be androgenetic. Coker, l.c.

Fig. 109. Resting spore of $O$. spinosa with spiny male cell. 'Tokunaga, '33.

Fig. 110. Knobhy resting spore of $O$. Aphanomyris. Petersen, '09, '10.

Fig. 111. Spiny parthenogenetic resting spore of $O$. dphonomycis. Whiffen, 't?.

\section{O. Pythii}

\section{(All figures after Butler, '07)}

Fig. 112. Three sporangia in a swollen spluerical hỵphal tip; supporting hypha with a cross wall.

Fig. 113. Nature sporangium.

Fig. 11t. Zoospores clustered at mouth of exit tubes.

Figs. 115, 116. Bean-shaped, isocont zoospores with refractive granules.

Fig. 117. Spiny, parthenogenetic resting spores.

Figs. 118 to 120 . Stages in the formation of spines on the resting spore.

\section{O. grucile}

1*ig. 121. Young parasite in a swollen lateral diverticulum. Butler, l.c.

Fig. 122. Sporangia and resting spores in short swollen lyphal branches, Butler, l.c. 


\section{PLA'TE 11}

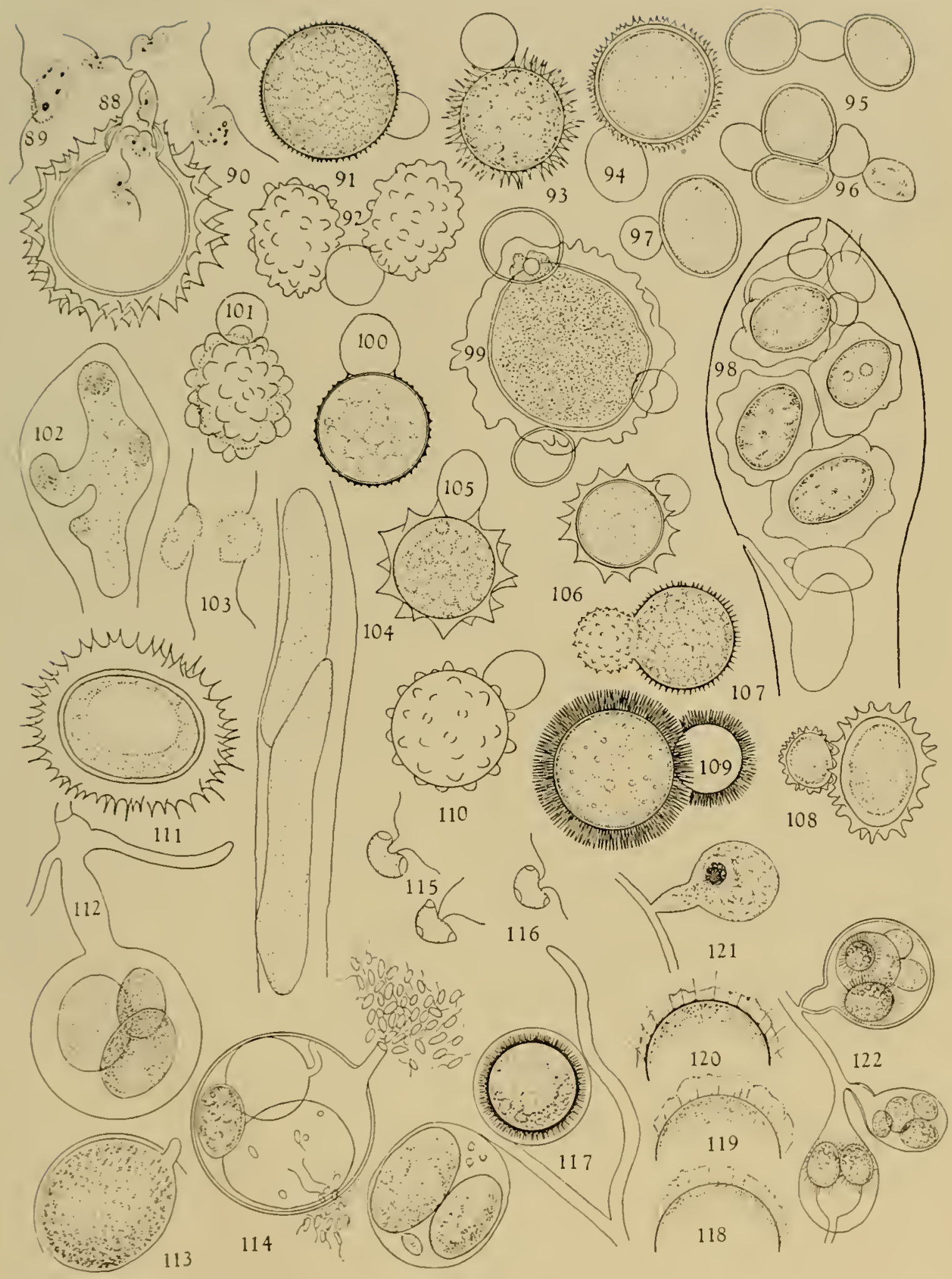


tensive tests under varying environmental conditions may produce different results.

Diehl made an intensive biological study of this species by growing its host under various cultural cnvironmental conditions. He found that the young thalli may change their position in the galls regardless of the strcaming of the host protoplasm and thus show independent amoeboid movement to some degree in the young stages of development. When infected hyphae of the host are transferred to agar the cxit tubes of the parasite may grow out into filaments $200 \mu$ to $567 \mu$ long. Under such cultural conditions, the sporangia may mature and produce normal zoospores. Diehl has also found that resting spore formation occurs abundantly at low temperatures. and that 1 to 3 so-called male thalli may fuse with the larger female cell.

O. SAPROLEGNIAE var, laevis Coker, 1923. The Saprolegniaceae, 1. 185. Pl. 62, figs. 1-6.

Zoosporangia solitary or up to seven in a cell, hyaline, smooth, spherical, oral, ellipsoid with 1-2 tapering exit tubes of variable length which project only slightly beyond the host cell. Zoospores small. Resting spores oval or elliptical, thick-walled and smootli; companion cells, 1-2, spherical, oval, elliptical, hyaline. and smooth; germination unknown.

Parasitic in Saprolegnia ferax and $S$. monoica in North Carolina, U. S. A.

O. INCRASSATA Cornu, l.c., p. 146, pl. 4, fig. 12.

O. Suprolegnicue Fischer, 1.c., pp. $34,38$.

O. mujor Maurizio, 1895. Jahresb. Nat. Ges. Graubundens $38: 15$, figs. $1-9$.

O. rexens Barrett, 1912. Ann. 13ot. 20: 231.

- Psentolpidium incressutum (Cornu) Fischer, 1.e., 1. 37.

Zoosporangia solitary or numerous, up to 12 or more in a lost lypha, hyaline, smooth, or covered with spines of various lengths. thicknesses, and abundance; spherical, $20-176 \mu$, oval ellipsoid, $6-30 \mu \times 90-121 \mu$, or elongate with 1 to 7 straight or curved. coiled, stout or filamentous and occasionally branched exit tubes of varying lengths. Zoospores isocont. oval, ellipsoid and somewhat elongate, slightly flattened on one side; flagella attached near the anterior end. Resting spores parthenogenetic or sexual, spherical, $30-60 \mu$, oval, ellipsoid, 40-80 $\mu \times 80-116 \mu$, rarely elongate, $5 \times 105 \mu$; exospore dark greyish-brown, thin and warty, or thick, undulating and wavy in contour, hyaline (?), yellowish-brown or bright-golden in color: endospore fairly thin or thick; contents coarscly granular with one to several small or large refractive globules: companion or male cells when present 1 to 4 per resting spore, hyaline and smooth, spherical, $18-30 \mu$, oral, $15-20 \times 20-32 \mu$; germination unknown.

Parasitic in Achlya racemosa (?) in France (Cornu, l.c.) and Denmark (Petersen, "09, '10); Achlya sp. (?) in Russia (Sorokin, '8:3, '89) and the U. S. A. (Sparrow, '33); Saprolegnia thureti, and S. monoica in Germany (Fischer, 92); S. thureti and S. hypogyna in Switzerland (Maurizio, l.c.); S. ferax, S. diclina, S. delica, S. mixta, S. monoica (?) S. littoralis, Isoachlya anisospora and I. unispora in the U. S. A. (Barrett, l.c.; Shanor, '39. '10), causing large terminal clavate swellings in the host hyphae.

According to Cornu this species is characterized by resting spores with a yellowish-brown wavy or undulating exospore as is shown in figure 98. The inclusion, however, of other species with warty and knohby resting spore as synonyms of $O$. incrassata changes this original distinction, and it is now impossible to distinguish this species by the character of the exospore alone.

Maurizio's $O$. major (fig. 99) is apparently the same as $O$. incrassata, but whether or not Fischer's $O$. Saprolegniae and Barrett's $O$. vexans are identical to Cornu's species may be open to question. Shanor ('10) came to the conclusion that they are identical as a result of his cross inoculation experiments. As is shown in table 1 . he found that $O$. incrassata is limited in host range to species of Saprolegnia and Isoachlya and will not infect Achlya. For this reason the present writer has inserted question marks after the Achlya species listed in the above host index. However, the number of Shanor's monozoospore infections is quite small, but if the general conclusion to be drawn from his results are confirmed it is obvious that the reports of Cornu. Sorokin, Petersen and Sparrow that $O$. incrassata occurs in Achlya species are incorrect. Shanor held that Cornu was probably in error about the identity of his host plants, since no apparent attempt was made to obtain them in pure culture for accuratc identification. Shanor further pointed out that infected hosts often became so distorted and atrophicd that identification is impossible unless they are grown in pure culture. Whether or not Sorokin, Petersen, and Sparrow also were mistaken about their host plants is impossible to determine at present. On the other hand. the possible existence of biological races of $O$. incrassata which parasitize Achlya must not be ignored in discussions of the host range of this and other Olpidiopsis species. Sorokin saw only oblong zoosporangia and no resting spores, so that it is not certain that he was dealing with $O$. incrassata. Fischer ('92) believed that Sorokin's fungus relates to $O$. fusiformis ( $P$. fusiforme) instead of to the former species. Sparrow observed nothing but ellipsoid resting spores with a hyaline undulating wall, which differs in color from the golden yellowish-brown exospore described by Cornu and Maurizio. As noted elsewhere, Petersen believed that $O$. incrassata ( $P$. incrassatum) Cornu is identical to $O$. Saprolegniae (P. Saprolegniae) Fischer and listed it as a synongm of the latter species.

O. IRREGULARIS Constantineanu, 1901. Rev. Gen. Bot. 13: 373, figs. 76,77 .

Zoosporangia solitary or up to 15 in a hypha, hyaline, smooth, oval. elongate, lobed and very irregu- 
Lar, size unknown. with one or two short cxit tulues which do not project beyol the surface of the host

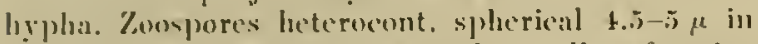
dismeter, or oval. liyaline with small refractive globules: witl onc slort flagellum directed forward and the longer ome backward in swimminer; often lying quicserent in a mass at the moutlo of the ('xit tule lxefore lecoming motile. Renting spores unknown.

l'arasitic in Saprolegmia sp.. ocensionally in association with Razella septigena, in Roumauia (Constantincium. l.c.) and Demmark (Sparrow. '3t). causing large terminal clavate swellings in the host lipphac.

This species takes its natue from the irregular shape (tig. 10.2) of the sjorangia. lut sporangium sloape is olviously a questionable diagnostic character in parasites as variable as Olpidiopsis species. Combantineanu was doubtful about its identity lecause no renting spores were found. and he assigned it tentatively to Olpidiopsis as a new species. It differs from the other parasites in Saprolegnia, as far as they are now known, by heterocont zoospores. As noted above. $O$. irregularis may be associnted with R. septigena, and Constantineaiu was of the opinion that it feeds of the latter's thallus.

\section{PARASI'TES OF ACHIIA}

\section{O. FUSIFORMIS Cornu, l.c., 1 , $14 \pi$, pl. $t$, figs. $1-4$.}

O. miner Fiscleer. I.c., ]. 39.

Prendotpiclium fuxifurme Fischer, 1.c. p. 3\%.

Zoosporangia bolitary or numerous, smootl or spiny. slongate, fuviform, $26-78 \mu \times 98-350 \mu$, oval, $7-10 \mu \times 21.7-80 \mu \times 120 \mu$. spluerical. 10-120 $\mu$. with 1 to 3 exit tubes. Zoospores isocont (?) eggshaped, oval. slightly elongate, $2 X+\mu$. Resting pores parthenogenetic or sexual, solitary or numerous, rellowish-brown. splerical. 30-60 $\mu$, соуcred with fine slort, or broadly eonical and triangular spines 11) to $10.5 \mu$ in lieiglit; contents coirsely granular with one to several refractive globules; companion or male cells when present 1 to 3 per resting spore. lyaline and smooth. oval. spherical 16-2 $1 \mu$; germination unknown.

l'arasitic in Achlya lencosperma, 1 . racemosa and Ichlya sp). in France (Cornu. l.c.) ; A. flagellata, 1. lescosperma, A. racemosa and $A$. polyandra in Germany [Cienkowski, '55 (?); Reinsch, '78 (?); lischer. '82. 'y2; Minden, '11]; Achlya sp.. and Sia prolegnia sp. ('), in Russia (Sorokin. '83, '89); Achlya sp.. in Demmark (Petersen. '09. '10); $\mathrm{A}$. flagellata and I. flagellata vir. yezoensis and $d$. racemosa in Formosa and Jip)an (Sawadia, '16, '19; Tokunaga. '3.3); Ichlya sp.. A. Haycllata, il racemosa, . I. imperfecta, I. lilebsiana, and Saprolegnia sp.. (:) in the U.S. A. (Sparrow. '3" : Mattlews, '35; Slanur. '3!). '10); Ichlya sp., in Fingland (Sparrow. "36). and .1. racemosa in Cotechoslovakia (Cejl?. '3 f). ('ausing large terminal and intercalary fusiform and clavate swellings in the host hyphae.
This species was maned fasiformis by cormu berause of the fusiform, elongate, and almost linear shape of its zoos]orangia. This claracter. howeser. is not very sprecifice. since fusiform and great!y clongate zoosporangia bave lecen reported in otler spec("ies as well. Furtlermore, resting spure's with broad triangular hyaline spines, whicl are reported to he characteristic of $O$. fusiformis, may" ocene in (). Achlyae and $O$. zarians aliso.

Slanor ('.10) found that $O$. fusiformis is linitud in lost range to $A$. racemosa and $A$. imperfecta and will not infect the other Achlya species which he tested (table 1). Particularly notewortliy is the fiact that it did not infeet. 1. flagellata, althonghl seven infection attempts were made. These results contradict the reports of Sawada. Tokunaga, and Matthews of its ocenrrence in this lost. Achlya imperfecta and . L. Lebsiana were leavily parasitized, lut 1. racemosa was infected only slightly in Shanor's experinents.

Sorokin and Sparrow are the only two workers who have reported $O$. fusiformis in Saprolegnia, and here again it is possible that they were mistaken about the identity of the host plants. On the other hand, they may equally well have lad (). Saprolegniae or $O$. incrassata at land. Sparrow leclieved that the fungus which Petersen reported as $O$. fusiformis relates to $O$. Aphanomyces ( $O$. luxurians). lut this is unlikely inasmuch as the latter species is limited in host range to I phanomyces.

As has been pointed out elsewhere, the parasite of A. imperfecta and A. flagellata which Coker (2:3) deserilsed as $O$. Saprolegniae Fischer may possillly. relate to $O$. fusiformis or $O$. Tarians, or in part to both species.

Whether O. index (Coruu) l.c. 1) 1.5.5, pl. 3, (fig. 11 ) is a ralid species or identical to $O$. fusiformis is not certain. Cormu descrihed it as a parasite of Achlya sj., usually with solitary, very large elliptical zoosporangia and resting spores and echinulate companion cells (fig. 107). No measurements were given of the size of the sporangia, zoospores, and resting spores. The presence of echinulate companion cells was nevertheless regarded by Cornu as specific, and he accordingly diagnosed the parasite as a distinet species. However, it is very dombtful that the occurrence of echinulations and spines on the conpanion eells is a specific character. since hotl smooth and sping male cells have leen repurted in $O$. iarians, O. currispinosa, and (). brezispinosa.

Olpidiopsis spinosa (Tokunaga. "3:3. 'Trans. Sap)poro Sat. Hist. So(. 13:25. 1'1. 2. figs. 10-11) prarasitizes A. flagrllata and orenrs in association with O. fusiforme and (). minor in Japan. 'Tokunaga deseribed it as follows: Zoosporangia solitary or numerous, hraline. smootl. ellipsoid. clomente or cylindric:al, $31-61 \mu \times 92-198 \mu$. with one or two exit tubes; \%oospores isocont. ellipsoid or clongate, si\%t unknown, with the Hagella attached laterally ne:ar the anterior end; resting spores liyaline. splecrical. .) $-73 \mu$. covered with nunerous fiuc. 9.6 $\mu$ long spines; germination unknown; companion cells siu- 
gle, hyaline, globose, $25.2 \mu-32.4 \mu$, covcred with numerous fine spines.

The size and shape of the sporangia of this species are strikingly similar to those of $O$. fusiformis, and besides the presence of long, fine spines on the companion cells (fig. 109) there are few or no charaeters to distinguish it from the latter species. While the spines on the resting spores of $O$. fusiformis and O. minor arc reported to be loroad and triangular, it is not improbable that they vary considerably in thickness, shape and length and may attain the dimensions of those deseribed by Tokunaga. The present writer is accordingly inclined at present to regard $O$. spinosa as a synonym of $O$. fusiformis.

It is quite possible that Pseudolpidinm stellatum (Sawada, 1912. Spec. Bull. Agr. Expt. Sta. Formosa, $3: 70$, pl. 8, figs. 11-16) is synonomous with this speeies also. Sawada found this species in $A$. prolifera in 1912 and 1919 in Japan, and it was subsequently reported by Tokunaga in 1933. Zoosporangia and zoospore were not observed, and the resting spores were reported to be hyaline, spherical, ovoid, or globoid, $24-100 \mu$, and covered witl long 9-2.4 $\mu$. pointed and sharp spines. No malc or eompanion cells werc found. Sawada reported that $I$. stellatum may occur independently or in association with $O$. fusiformis.

O. VARIANS Shanor, 1939. Jour. Elisha Mitchell Sci. Soc. 5.5: 171. Pl. 94 .

Zoosporangia solitary or numerous, smootl, warty or spiny, spines up to $7 \mu$ in length, spherical, oval, ellipsoid, $40-1.10 \mu$ by $60-350 \mu$, frequently $80 X$ $200 \mu$, with 1 to 5 exit tubes. Zoospores isocont, oval to clongate, $2.3-3 \mu \times 3.8-4.6 \mu$; flagella 1.2 to t.6 $\mu$ long. Resting spores yellowish-brown, spheri(a) $26-83 \mu$; exospore lyyalinc to yellowish in color, $1.2 \mu$ thick, usially bearing coarse, abruptly-tapering spines, 8.6 $\mu$ high, which are connected by a reticulnum; endospore yellowish-hrown, $1.7 \mu$ thick; companion or malc cells 1 to 2 per resting spore, usually splecrical, 17 to $30 \mu$, occasionally smooth, usually cnveloped by the spiny exospore of the resting spores, spines $1.7 \mu$ long; resting spore transformed directly into a zoosporangium in germination with an exit tube which usually penetrates the companion cell.

Parasitic in Achlya flagellata, A. racemosa, A. colorata and 1 . proliferoides in North Carolina, U. S. A. (Slanor, '39a, '39b, '40) causing large terminal or interealary swellings in the host hyphae.

shanor fonnd that this species is limited to the Ichlya species listed ahove and will not infeet $A$. americana, d. imperferta, A. klebsiana, A. recurra, 1. a piculata, .1. glomerata, nor any of the species of Saprolegnia, Aplanes, Protoachlya, Isoachlya, Aphanomyces, Dictyuchus, and Leptolcguia shown in talle 1. This species is highly variahle in sporangium size and shape as well as in the character of the exospore, and was nancd rarians because of its variability. The spines are broad and triangular as in some speeimens of $O$. fusiformis and $O$. Achlyae. (figs. 86,87 ), and some of the resting spores are strikingly similar to those of $O$. minor (fig. 106). Furthermore, the companion cells are usually enreloped ly the spiny exospore of the resting spore, although the spincs in the vicinity of such cells are usually shorter. A similar envelopment has been shown to oceur in $O$. Achlyae (fig. 66).

O. ACHLYAE McLarty (ad int.) 1941a. Bull. 'Torrey Bot. Cluh. 68:62, figs. 1-20. 1941h, 1hidl. 68: 75, figs. I-80.

Zoosporangia solitary or up to 50 in a hypla, smooth or covercd with fine or coarse noncellulosie spines or bristles, variable in size and shapc, spherical, oval, ellipsoid or elongate, 13.2-112.4 $\times 115-$ 666.+ $\mu$, with 1 to 3 exit tubes which may extcnd considerably heyond the surface of the host filament. Zoospores hyaline with numerous small refringent granules, oval or somewhat reniform 2.3$2.9 \mu \times 4.3-5.7 \mu$. usually about $3.1 \times 1.2 \mu$, with two approximatcly equal flagella attached laterally near the anterior end. Resting spores partlienogenetie or sexual, spherical or oval, 22.8-122.4 $\mu$, usually $41 \times 50 \mu$, brown, with several or usually one large refringent globule; endospore smooth cellulosic, 1 to $1.5 \mu$ thick; exospore noncellulosic, 1 to $11.4 \mu$ thick, covered with warty protuberances, small or large, narrow or broad-based spines, hairlike fibrillae, or with an entire, undulant or slightly serrate margin; companion or male cells 1 to 3 per resting sporc when present, thin-walled, hyaline, smooth, sometimes embedded in the exospore, oval or spherical; resting sporc transformed dircetly into a zoosporangium with an exit tube in germination.

Parasitic in Achlya flagcllata, London, Ontario, Canada (McLarty, '39, '10, '41), causing large terminal and intercalary swellings in the host lyphae.

McLarty diagnosed this parasite temporarily as a new species, until the other Olpidiopsis species with which it appears to be identical have becn more intensively studied. As is shown in Plates 9 and 10 , it is highly variable in structure and may produce resting spores with exospores which are characteristic of most species of this genus. In gencral it resembles $O$. fusiformis most closely, so that the writer and his student, McLarty, were inclined to regard it as closely related or identical to this species. But if Shanor's data that $O$. fusiformis will not infect $A$. flagellata are correct, these two species are different in host range at least. Since $O$. Achlyae occurs on the same host and shows much the same variations as $O$. varians, it is possibly identieal to the latter species. Although spiny companion cells have not been observed in $O$. Achlyae, this does not exclude the possibility of jts heing the same as $O$. rarians. On the other hand, it is equally probal,le that $O$. zarians, O. Achlyae and possibly $O$. index and (). spinosa may be biological varicties or races of $O$. fusiformis which are limited to particular hosts. If this proves 
ta lo true, all . Ichlya-inhahiting parasites may jussibly he areuped as a single species with several possilhe pliysiolengical races of varictic's. 'lo determine this possiluility an intensive study of the degree of morplological vin riation of all species and their host range must lie made.

\section{PARASITE OF APHANOMVCLS}

O. APHANOMYCIS (urutu. l.c., p) 11s. pl. t, figs. 5-11.

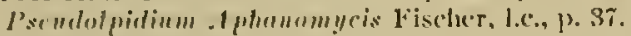

(1. tuxurians 13arrett. l.c.. 1). 231. l'). 23 , figs. 1, 5, 6, 9-14,

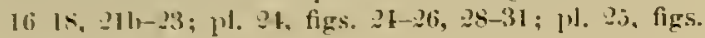
H3- $16:$ i 1.26.

Zoosporangia solitary or mumerous, up to 20 or more in a hypha. sumesth, or spiny, spherical. oval. fusiform and clongate, dincusions unknown; one to everal exit tules which may extend considerably hevond the surface of the liost cell. Zoospores isocont. orial. egg- and slightly bean-shaped, size unknown: coming to rest in a mass at the moutl of the exit tule for a few mintes and then swinming away ; Hagella inserted at ( $(\vdots)$ or near the anterior end. Resting spores parthenogenetic or sexual, brown, oval. spherical. 2.5-50 $\mu$ : endospore thick. exospore comparatively thin and covered with conical spines. 2.5 $\mu$ in heiglit. or blunt warts; contents grauular with ont or morc large refractive globules; compinion or male cell, when present 1 to 3 per resting spore. lyaline. smootl. oval. ellipsoid. splerical, 10-25 $\mu$. germination unknown.

Parasitic in Iphanomyres sp. and Pythium sp. (?) in France (Cornu. l.c.; Danereard, '90); Aphanomyces sp.. in l)emmark (1'ctersen, '03, '09, '10) and Cicrmany (Minden. '11); . Laeris in India (Butler, 07; Sydow and Butler, 07 ; Butler and Bishy, '31) and the U. S. A. (Barrett. l.c.: Shanor. '39, '10) and . 1. cladogamous (Whiffen, i2) causing large broadly fusiform interealary and almost spluerical terminal swellings in the host lyphac.

As noted ahove. Dangeard reported this species as a parasite of P'ythim, but Butler ('07) and Sinanor were unable to secure infection of $l$ '. monospermum, $I^{\prime}$. proliferum, $l^{\prime}$. gracile, and $J^{\prime}$. aphanidermalum with it. Butler nevertleless believed that the resting spore figurea by Dangeard relates to $O$. Iphanomyces, hut as IIinden ('11) and Sllanor ('3y) sugrested it is probably the resting spore of (). ('seudolpidium) I'ythii. Shanor ("HO) was muable to transfer O. Aphanomycis to Aphanomyces stellatus, Achlya, Saprolegnia and other water molds. and concluded that it is limited in loust range (1). I phanomyces larzis. II iss Whiffen. however. repurted its oceurrence in .1. cladogamous. It is to be nested. lowever. that lier fungus did not infect $\lambda$. laezis, which suggests at once that it may be a physological race of $($ ). Aphanomycis. 'This remains to be shown. however. from more extensive cross inoculation experiments involving Sajpolegnia, Ichlya and other similar host species.

\section{PARASTTES OHE P'THILAH}

\section{O. PYTHII (Jutler) ennl, nuv.}

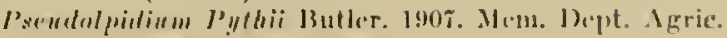
Judin. 13ot. Ser. 1 X゙o, s:127. Pl. 7, figs. 9-16.

Zoosporangia solitary or muncerous, liyaline, smouth, aral, and collipsoid, up to $35, \mathrm{~s}$ in the greatest dinneter, with a single texit tube of varying length which extends for a short distance leyond the surface of the host. Zoospores isocout, hyaline, uniequilateral, somewhat kidney-shiaped with one to several small refractive granules; Hagella laterally inserted: swarming in the veinity of the exit canal for a brief period, then coming to rest for a few minutes in a densc eluster; finally swimming away slowly. Resting spores parthenogenetic, solitary or numerous, often in association with zomsporangia. (val or spherical, $19.2-30 \mu$, lrown. comparatively thin-walled and covered witl fine, thread-like, short. evenly spaced spines; germination unknown; conpanion or male cells lacking.

Parasitic in Pythium monospermum, P. rostratum, $I^{\prime}$. verans, and $I^{\prime}$. intermedium in France (Butler, l.c.), Pythium sp.. in Germany (Minden, '11), l'. oryzae in Japan ('lokmaga, '33), and 'ythium sp., in England ('jparrow, '36), causing oval, spherical, olypyriform or balloon-shaped enlargements at the end of the host hyphae or in lateral diverticula, and oceasionally leading to septation of the liyplise.

O. GRACILE (13utler) comb. nov.

P. yrurile l3utler, l.c., 1. 129, pl. 7 , figs. 1-8.

Zoosporangia solitary or numerous. np to 10 in il single swelling. livaline, smooth or spiny, splerieal. $+-52 \mu$. with 1 to 5 contorted and swollen exit tules of varying lengths which may project considerals!y beyond the surfiace of the host cell. Zoospores, isocont (?). hyaline, obclavate, elongate, and somewhat curved with onc to several minute refractive granules, size unknown; one flagellum inserted near the anterior cud. the other laterally; swinning motion smootl. body of spore often revolving on its long axis. Resting spores parthenogenetic. single or numerous, occurring in association with the zoosporancria, spluerical to oval, je-27 $\mu$ exclusive of spines, ycllowish, containing a large refractive globule surrounded hy a peripheral layer of vacuolate proteplasm; cendospore .7 to $1.2 \mu$ thick. exospore 1.7 to $2.5 \mu$ thick and covered with long. $1 \mu$, tilpering. thick, crowded spines; germination unknown: companion or mile (e)lls liscking.

Parasitic in l'ythinm intermedium in Finnce (Butler. l.c.) and $I$. rostratum in the L. S. A. (IIhiffen, 't2) ('ausing terminal culargenents and lateral. oval- or ballow-shaped diverticula in the host lyphate which miy he $80-90 \mu$ in their greatest dianucter.

Whether the zoespores are heterowent or isocont is uest certain from Butler's description. He reported that one Hagellum is inserted near the anterior end while the second one is lateral, but his figure (fig. 
12) suggests that they are both lateral in position. According to Miss Whiffen, $O$. gracile will not infect $P$. torulosum, $P$. pulchrum, $P$. proliferum nor the unidentified Pythium hosts of $O$. brerispinosa and $O$. currispinosa.

O. CURVISPINOSA Whiffen, 1949. Amer. Jour. But. $29:$ :i10. Fiyss. 1, 5, :1.

Zoosporangia solitary or numerous, spherical to oval, $72-68 \mu$ in greatest diameter, hyaline, smooth or eovered ly short bristles, with one to three exit tubes. Zoospores with nunerous oil glohules. elongate and somewhat reniform, size unknown; flagella of about equal length and attached near anterior end. Resting spores liyaline, spherical to oval, 17$2.4 \mu$, containing a large refractive globule surrounded by vacuolate protoplasm; exospore covered by curved spines up to $5 \mu$ in length. Companion or male cell consistently present, hyaline, spherical, or oval, It-20 $\mu$, smooth or with short, closely-set spines; germination unknown.

Parasitic in Pythium sp., and $P$. torulosum in North Carolina, U.S. A., causing large terminal or intercalary swellings in the host hyphae.

\section{O. BREVISPINOSA Whiffen, l.c., p. 610. Figs. $2,22,27$.}

Zoosporangia solitary or numerous, oval, spherieal, I0.6-68.4 $\mu$, with one to thrce exit tubes. Zoospores elongate and somewhat reniform with several oil globules; flagella of about equal length and attached near the anterior end. Resting spores dark brown, spherical to oval, J0.6-45.I $\mu$, containing a linge refractive globule surrounded by vacuolate protoplasm: exospore 1.7-2.5 $\mu$ thick, covered by short, fine spines up to $3.5 \mu$ in length, endospore $.75-1.32 \mu$ thick; companion eell consistently present, oval, spherical, 7.1-25.5 $\mu$, smooth or spiny; germination unknown,

Parasitic in Pythium sp.. from Louisiana, U. S. A., causing large terninal and interealary swellings, up to $125 \mu$ in diameter, in the host hyphae.

'This species is limited in host range to an unidentified species of $P$ 'ylhium and will not infect $P$. rostratum nor the host of $O$. curvispinosa, according to Miss Whiffen's cross inoculation experiments.

\section{PARASITES OF ALGAE}

O. SCHENKIANA '\%opf, 188.1. Nova Aeta Ksl. 1.eop.Carol. Deut. Akad. Nat. 47: 168. Pl. 15, figs. 1-3\%.

Plencystidium parusiticum Fisch, 1881. Sitzh. Phỵs.Med. Soc. Erlangen 16: 60. Figs. 2t-39.

Olpirliopis promsition (Fiseh) Fischer, 1892. Rahenhorst's Krypt'fl. I, t: 40.

Jiplophysa schenkiuma (Zoj) Schrocter, 1897. Engler und Prautl, Die Nat. Pflanzent. I, 1: s.5.

J'seudolpioliopsis schrokinenu (7opf) Minden, 1911. Krypt'fl. Miark 13randenburg 5: 2.57.

1. pretasilica (Fisch) Minden, l.c., 1).25s.
Zoosporangia solitary or numerous, hyaline, smooth, spherical, oval, ellipsoid, egg-shaped, elongatc, 21.6-26.4 $\mu \times 30-81.6 \mu$, with one or two stout, short or elongate, up to $60 \mu$ long. straight or

\section{PLATE 12}

\section{O. "mrecill}

Fig. 123. Mature zousporangium with oxit tubes; accomplanied by a resting spore. Butler, l.c.

Figs. 124, 125. Pyritorm heterocont (?) zoospores with refractive bodies. Butler, l.c.

Fig. 126. A large diverticulum with numerous sporangia and resting spores. Butler, l.c.

Fig. 127. Smooth-walled resting spore. Whiffen, '42.

\section{O. currispinose and O. brerispinosa}

Fig. 198. Resting spore of $O$. currispinosa with long curved spines. Male cell spiny. Whiffen, J.e.

Fig. 1 39 . Spiny resting spore and male cell of $O$. brerispinost. Whiffen, l.c.

\section{O. schenkiana}

Fig. 130. Infection of Spirogyra cell. Zopef, '84.

Fig. 131. Cellulose plug on cell wall at point of entry of germ tube. Seherffel, ' 25 .

Fig. 132. Forked germ tube, and young naked vacuolate parasite in host cell. Seherffel, l.c.

Fig. 133. Young parasite next to larger lost nueleus (P. paraxiticum). Fisch, '8.t.

Figs. 134 to 136. Zoosjorangia and emission of zoospores. Zopf, l.c.

Fig. 137. A flagellate amoeboid primary swarmer with contractile vacuole. Scherffel, l.c.

Fig. 138. Side view of pyriform, heterocont secondary swarmer with contractile vacuole. Scherffel, l.c.

Figs. 139, 140. Optical and cross-section views of same. Scher ffel, l.c.

Fig. 14l. Early stage in resting spore formation. Z(n)f, l.c.

Fig. 142. Resting spore with one companion cell. Zopf, l.c.

Fig. 143. Resting spore with four companion cells. De Wildeman, " 96.

Fig. 144. Sinilar resting spore (P. purasitieum) Fisch, l.e.

Fig. 145. Gernination. Only one flagellum shown on zoospores. \%opf, l.c.

Figs. 1.46 to 148 . Koosporangium and resting spores of O. zopfi. De Wildeman, l.e.

Fig. 149. Resting spore of $O$. fibrillosa. Spines not shown. Two male cells in tanden. De Wilkeman, l.c.

Fig. 150. Same with fibril-like spines. De Wildeman, l.e.

Fig. 151. Resting spore of $O$. appendiculata. De Wildeman, l.c.

$$
\text { O. Oedogoniorum }
$$

(All figures after Scherffel, 25 )

Fig. 15:. Nature vacnolate zoosporangium.

Fig. 153. Isocont primary swarmer.

Fig. 151. Cystospores.

Figs. 155, 156. Resting spores in clongate hyaline vesicles with attached companion cells.

\section{O. Ricciue}

Fig. 157. Empty zoosporangium in a rhizoid.

Fig. 1.58. Anteriorly biflagellate, heterocont zoosjores.s.

Figs. 159, 160. Resting spore with companion cell, and elongate parthenogenetic (?) spore. 
PLATE 12
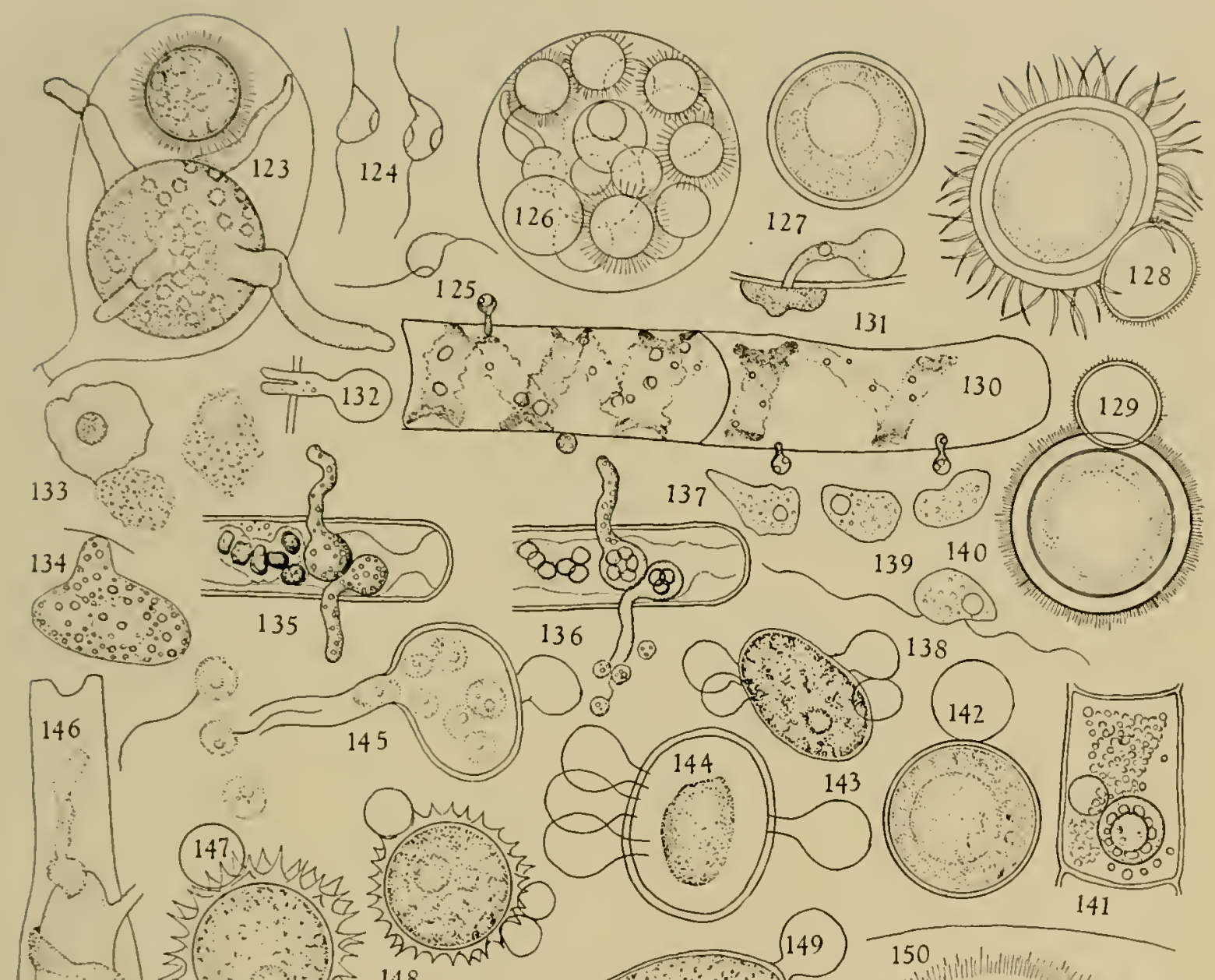

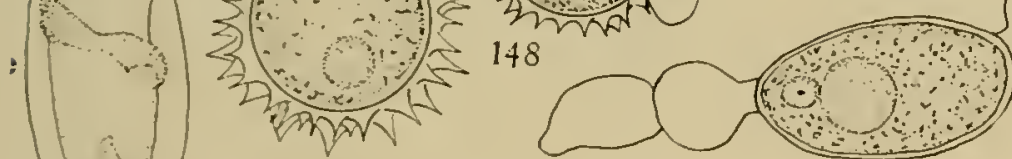

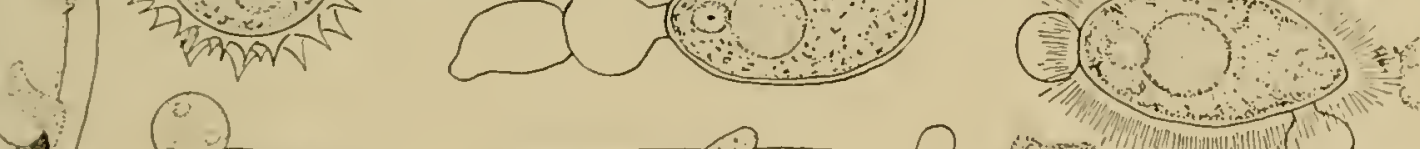
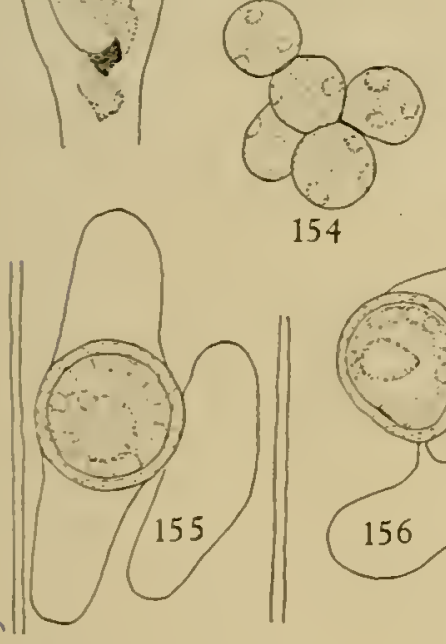

54
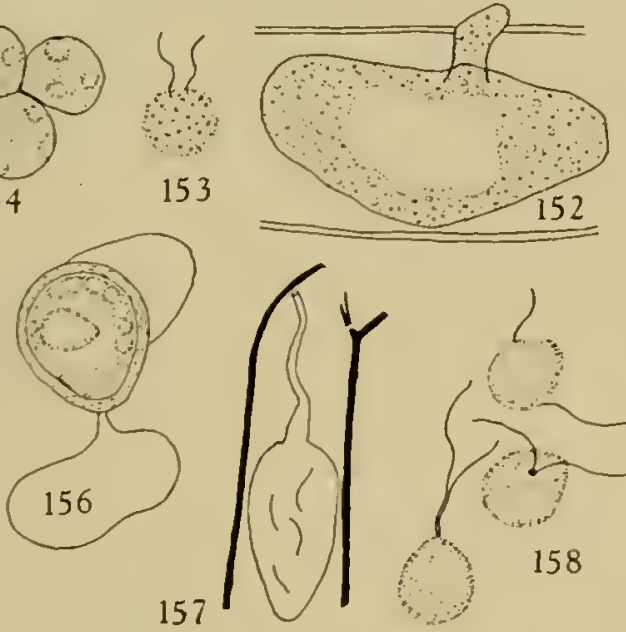

R sem
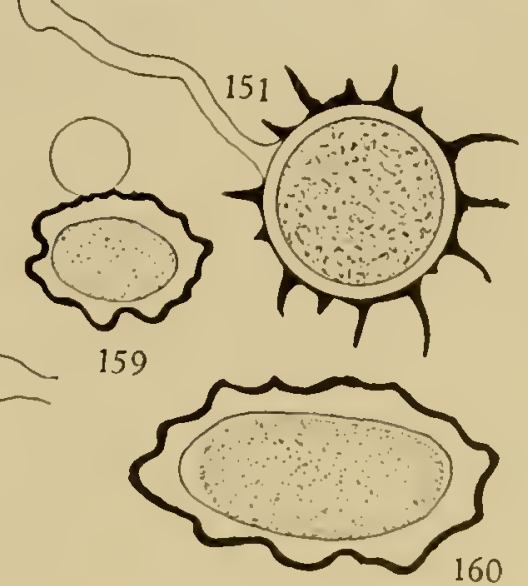

Olpidiopsis 
eurved exit tubes whieh may projeet considerably beyond the surf ace of the host eell or extend through adjacent cells. Zoospores heteroeont, oval, pyriform, $4 \times 6 \mu$, and slightly bean-shaped; hyaline with several small refraetive granules and a eontractile vaeuole; emerging singly, fully developed, and swimming directly away, or emerging and lying in a mass for a few minutes at the mouth of the exit tube before becoming amoeboid and flagellate and swimming away; flagella lateral (?), shorter flagellum extending forward and the longer one baekward in swimming. Resting spores hyaline, smooth, oval, egg-shaped or spherical, 30-40 $\mu$, thiek-walled with a large refraetive globule; companion or male eells 1 to 5 in number, hyaline, smooth, oval or spherical, $16.8-21.6 \mu$; resting spore transformed direetly into a zoosporangium with an exit tube in germination.

Parasitie in Spirogyra sp., Mougeotia sp., and Mesocarpus sp., in Germany (Zopf, l.e.; Fiselı, l.e.; Minden, '11); Spirogyra sp., in Hungary (Scherffel, '25); Spirogyra sp., in Belgium (de Wildeman, '90, '91, '96), Roumania (Constantincanu, '01), India (Butler, '07; Butler and Bisby, '31), Japan ('Tokunaga, '33), causing no or only slight hypertrophy of the host eell. The writer also has frequently observed this parasite in Spirogyra sp., in the vieinity of New York.

Fiseh and Zopf, among the early workers, deseribed the zoospores as uniflagellate, and for this reason Minden ineluded this speeies in his new genus, Pseudolpidiopsis. Seherffel's observations, however, leave no doubt about the number of flagella, and Zopf's species may now be returned to the genus Olpidiopsis. Obviously the previous investigators had failed to observe the second flagellum. Fiselh's Pleocystidium parasiticum is ineluded here as a synonym of Zopf's speeies, since it occurs in the same host and appears to have the same structure and type of development. Fiseher and Minden regarded both speeies as distinet because of the presenee of up to five eompanion cells on the resting spores of $P$. parasiticum, but de Wildeman found up to four male cells per resting spore in $O$. schenliana also. In view of the variations whieh Maurizio, Barrett, Diehl, McLarty, Shanor and others have obserrcd in other speeies of Olpidiopsis, the number of eompanion eells present is a questionable diagnostie character.

O. ELLIPTICA (Schroeter) Fischer, l.c., p. 41.

Diplophysin ellipticn Schroeter, 1886. Cohn's Krypt'fl. schlesiens 3: 196.

Psemdolpidiopsis clliptica (Schroeter) Minden, I.c., p. 260.

Zoosporangia and zoospores unknown. Resting spore obliquely ellipsoid, slightly less in diameter than the host cell, and eovered with fine, seattered spines; companion or male eells slightly smaller than the spores, brown and smooth; germination unknown.

Parasitic in Mesocarpus sp., in Germany.
This speeies has been reported only onee, but it is not altogether improbable that other speeies deseribed from Mesoearpus may be identieal or closely related to it. It is reported to differ from $O$. schenliana chiefly by the presenee of spines on the resting spores.

O. SOROKINII de Wildeman, 1890. Ann. Soc. Belge Nicro. 14: ??:? fig. 7 .

Zoosporangia solitary, hyaline, smooth, elongate, sae-like or cylindrieal with a single short exit tuhe whieh ends flush with the surfaee of the host cell. Zoospores small. Resting spore mknown.

Parasitic in Tribonema (Conferza) bombyeinum in Belgium.

This is a very donbtful speeies whieh de Wildeman thought might he identieal to $O$. fusiformis var. Oedogoniarum Sorokin. Later in his Census Chytridinaearum ('96), however, he listed it as Olpidium sorolinii. Inasmueh as the resting spores are unknown its validity as a member of Olpidiopsis is rery questionable.

O. ZOPFII de Wijdeman, 1895. La Notarisia 10:34. 1896, Ann. Soc. Belge $\mathbf{A}$ icro. 20 : 25 , pl. 1, figs. 1-3, 5-7.

Psculolpidiopsis zopfii (de Wildeman) Mlinden, I.c., p. 259 .

Zoosporangia solitary or numerous, hyaline, smooth, spherical, egg-shaped or ellipsoid with a single exit tube of varying length whieh usually projeets beyond the surface of the host eell. Zoospores mnknown. Resting spores spherieal, 16-22 $\mu$, with one or morc refractive globules, thick-walled and eovered with numerous stout, liroad-based, abruptly tapering spines; companion eells 1 to 3 in number, small, oval, spherieal, $12 \mu$, smooth, hyaline; germination unknown.

Parasitie in Spirogyra sp., in I.uxemburg, eausing local swellings, up to twiee the normal diameter of the filaments.

O. FIBRILLOSA de Wildeman, 1895. l.c., p. 34. 1896. Ann. Soe. Be]ge Micro. 20: 27. PJ. \&, figs. 13, 1t, $18,19$. Psendolpidiopsis fibrillosa (de Wildeman) Minden, I.c., p. 259.

Zoosporangia solitary, hyaline, smooth. oval or ellipsoid, with a single exit tube more or less broadened at the base. Zoospores unknown. Resting spores hyaline, thiek-walled, spherieal. 20-25 $\mu$, oval, eggshaped and ellipsoid with one to several refractive globules; exospore profusely covered with fine, radially oriented hair-like spines or fibrillae whieh give it the appearanee of a halo; companion eells, 1-3, hyaline, smooth, spherieal or pyriform, oeeasionally oeeurring in tandem; germination mnknown.

Parasitie in Spirogyra sp., in Belgium (de Wildeman, l.c.) and Germany (Minden, l.e.), eausing only slight swelling of the host filanents. 


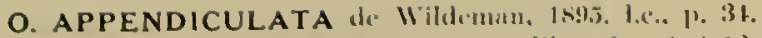

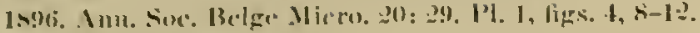

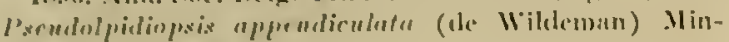
den, l.e.. 1). :59).

7oosporangia solitary. hyaline, smooth, splerieal. osal or cllipond with i single exit tule which does nol project fir heyond the surfice of the host cell. Zoospores unkuown. Resting spores spluerical, 1:3$25 \mu$ thick-wallnd, covered with clongate abruptly lapering. ratler well scparated spines; companion cell single. hyaline, smonth, vermiform and filamentous. : $0 \mu$ long. and inflated at the end; germination unknown.

l'arasitic in . Mesocarpus sp.. in Belgium, causing marked local swellings up to four tines the normal diminter of the filaments.

O. OEDOGONIORUM Silherffel, 192j. Arch. Protisk. j:: 109. 1'. 4. figs. 199-207c; pl. 5, figs. 20\%d-208.

O. fusifurmis var. Ordnguniurum Sorokin, 18s3. Arch. Bot. Norl. France 2: 39, fig. 31. 1859, Rev. Mycol. 11: s!. 1'l. s0. fig. 99.

Otpielium Orelugoniurum (:) de Wildeman, 1894. Ann. sore. Jelge Miero. 1s: I.j. Pl. 6, figs. 9, 10.

Zoosporangia solitary or numerous, up to 5 in a cell. Iyaline, smooth, oval, clongate, sac-like, 5-7 X $50 \mu$. wilh one or two short, $3-4 \mu X+6 \mu$, tapering exit tubes which may project sliglutly beyond the lost cell. Zoospores isocont and diplanetie. lyyaline, oval and elongate, $5 \mu$ long. witl a snall refringent spot but no conspicuous ventral furrow; flagella lateral. one extending forward and the other backward in swimning; cystospores $3 \mu$ in diameter. Resting spores hyalinc. smooth. splierical, oval, ellipsoid, $10-12 \mu \times 1+\mu$, thick-walled; content coarscly gramular with scveral small refractive globules surrounding a large central onc; resting spore lying free within a lyaline. thin-walled, oval or cllipsoid resicle (oogonium ?); companion or male cell solitary, hyaline, ovial or spherical, $10 \mu$, germination unknown.

Paranitic in Oedogonium sp). in Hungary (Scluerffel. l.c.) and Tew York. C. S. A. (Sparrow, '33), destroving the content of the algal cell but not causing hypertrophy.

Schertfel helicved that $O$. fusiformis rar. Oedogoniarum Sorokin and Olpidium Oedogoniarum de Vildeman are identical to this species. Fischer ('y-2), however. listed Sorokin's fungus as a syonym of Olpidinm entophytum, while Minden regarded it as identical to de Wildeman's (). Oedogoniarum. Since Sorokin and de Wildeman olserved only zoosporangia the questions of identity and synonomy of their species camot le answered at prescint. although both speceies ocenr in the sanc liost.

'The development of the resting spore in a vesicle. which ticherffel and Sparrow interpreted as a true oospore in an oogonium without periplasm. and the manner of zoospore formation and belavior arc strikingly similar to those of Iagenidium Oedogonii Scherffel, while the thallus and zoosporangia are like those of olpidiopsis. lior these reasoms sicherdfe] was uncertain as to which of the wo genera this s]w-

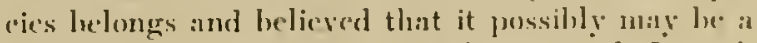
transition form between Olpidiopsis and Iagenidinm.

O. ANDREEI (I agerheim) nuv. comb.

Pleotrachelus anetriei Laperheim, 1899. Yoner 1: 1366.

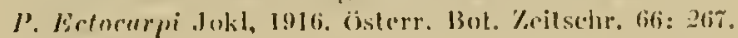

l's. I, .;.

letersonia (Olpiliopsis) andrici (Iagerheim) Sparrow, 1936. 13iol. 13ull, 70: 215. Figs. 1-8, 12.

Zoosporangia solitary or mumerous, "1] to 23 in a cell, splicrical, $3-80 \mu$, oval, cllipsoid, $8-15 \mu \times$ $15-25 \mu$, polygonal or irregular with $1-10$ tapering or irregular exit tulies. $3.5-10 \mu$ in diancter anct $6-78 \mu$ long, which may penetrate adjacent cells and project to the outside heyond the surface of the liost, or open within the host cell. Zoospores ellipsoid, somewhat pyriform, arched or curved $3 \times+-5 \mu$, with a large refractive spot at the narrow anterior and hroarl posterior end ; occasionally liberated witlin the host cell. Resting spores, parthenogenetic (?) or sexual, spherical or slightly ellipsoicl, 12$23 \mu$, browu, smooth and thick-walled; companion or male cell when present single, hyaline, spherical, $5-12 \mu$, or slightly oval; germinating by becoming transformed directly into a zoosporangium witl an exit tulbc.

Weakly parasitic and possilhly saproplyytic in the regetative cells and plurilocular sporangia of 'Spongomorpha sp., in King Charles Land (Iagerlieim, l.c.) ; Acrosiphonia incurca, and Acrosiphonia sp., in Greenland and Demmark (l'etersen. '05; Sparrow, '3t) ; Eetocarpus granulosus in the Gulf of Trieste (Jokl. '1 6 ), and F. silieulosus in Mass.. U. S. A. (Sparrow, '36) ; cansing slight hypertrophy" of the plurilocular sporangia in Ectocarpus, and degeneration of the plastids and remainder ol the protoplasm.

Althougl Sparrow placed this species in l'etersenia, he nevertheless believed that it should be referred to Olpidiopsis. Its zoospores. however, are strikingly like those of l'ontisma. 'The male and female thalli which fuse to form the resting spore may be cqual in size or quite unequal, so that sexual reproduction in this species may he iso- or lacterogamous, according to Sparrow. Occasional resting speres without attached empty male cells may also be found. and they have doubtless developed partlenogcnetically without fusion.

Sparrow furtler regarded I'. Eetocarpi Jokl as identical to this species, and the present writer is listing it provisionally as a synonym. Howerer. inasmuch as Jokl failed to ohserve fiagellate zoospores and resting spores its identity to $O$. andrexi is rery doubtful at prescnt. Aceording to lis olsscrvations, the sporangia may occasionally occur extramatrically and send their exit tulucs into the algal cell (fig. ifis). He further described and figured the newlyentered zoospores and young thalli as maked and amochoid with sereral jong tenuous, more or less 
radially oriented pseudopods (fig. 162). Jokl believed that the amoeba may often migrate towards the mucleus, as in $O$. schentiana and $O$. Oedogniorum, and engulf it. Very shortly, however, the amoebae retract their pseudopods, round up, and grown into large thalli. Petersen and Sparrow apparently failed to find extramatrieal thalli and the amoeboid stages, and it is quite possible that Jokl's fungus relates to another species.

\section{PARASITES OF RICCIA AND INSEC'IS}

O. RICCIAE du Plessis, 1933. Ann. Bot. 47: 761. Figs. $1-12$.

Zoosporangia solitary or up to 12 in a rhizoid, oval, elliptical, $20-35.7 \mu \times 2+40 \mu$, opening by an irregular fissure or an exit tube. Zoospores heterocont, lyaline, globose or slightly oroid, 2.4-4 $\mu$, swarming in the sporanginm lefore deliscence, liberated within the host cell or to the outside; flagella anterior, $8.3 \mu$ and $17.5 \mu$ long respectively, shorter flagellum directed forward and longer one backward in swimming. Resting spores parthenogenetic (?) or sexual, globose, elliptical, elongate or cylindrical, of ten laterally and terminally depressed, 12.8-32 $\mu$ $\times 1+4-48 \mu$, hyaline or light brown, with a thick warty exospore; companion or male cell livaline, smooth and spherical; gernination unknown.

Parasitic (?) in rlizoids of Riccia sp., South Africa, withont eansing hypertroplyy.

O. UCRAINICA Wize, 1904. Bull. Intern. I'Acad. Sci. Cracovie. 1904: 713. Figs. la-ig.

Thallus broadly oval, $35 \mu$ in diameter. Zoosporangia and zoospores unknown. Resting spores apparently formed by the contraction and encystment of the thallus content, and lying loose and free in a vesicular membrane until mature, orange or golden in color, spherieal, $20-30 \mu$; contents granular witl one large $15-25 \mu$, or several small, $3-5 \mu$, refringent globules; wall thick, sculptured and reticulate; companion cell lacking.

Parasitic in the larvae and pupa of Cleonus puntiventris and Anisplia austriaca in Repiszna, Ukraina, and Ruthenia, filling the insects' bodies with an orange-colored granular powder.

There is little, if anything at all, in the life cyele of this organism as described by Wize to justify its inclusion in Olpidiopsis. Sparrow ('39) believed that Wize's fungus relates to Myrophagus ucrainicus Sparrow, a chytrid which Thaxter lad collected in 1927. Petch ('10) likewise held that his earliernamed Entomophthora (Tarichium) rcticulala is identical to Wize's and Sparrow's species.

\section{PSEUDOLPIDIUM}

Fischer, 1892. Rabenh. Krypt'fl. I, 4: 33.

(PLATE 13, Figs. 171-190)

Thallus intramatrical, appearing more or less naked lut inmiscible with the host protoplasm when young and becoming enveloped by a sharply-defined wall at maturity. Zoosporangia solitary or numerous in a host cell, smooth, variously-shaped with one to several exit tubes of variable diameter and lengtl which nua often extend considerably beyond the surface of the host cell. Zoospores hyaline with one to several refractive bodies: somewliat egg-, bean-, or kidney-slıaped, oval, elongate, and pyriform; heterocont or isocont (?), flagella laterally inserted

\section{PLATE 13 \\ O. andriei}

Fig. 161. Infection of Ectucarpus cell. Sparrow, '36.

Fig. 16:. Young amoeboid thallus with psendopods, approaching host nucleus at right. (Pleotruchelus Ectoc(crpi). Jok], '16.

Fig. 163. Older vacuolate thallus enveloped by a distinct wall. Sparrow, l.c.

Fig. 164. Abnormal, partially extramatrical thallus. Jokl, l.c.

Fig. 165. 7oosporangium. Sparrow, l.e.

Fig. 166. Free hand interpretative drawing of zoospore, heterocont (?). Sparrow, l.c.

Fig. 167. l'lasmogamy. Sparrow, l.c.

Fig. 168. Resting s]rore with small companion cell. Sparrow, l.c.

Fig. 169. Mature parthenogenetic (?) resting spore. Sparrow, l.c.

\section{Pseudolpidium}

Fig. 170. Cyst of Glenodinium with two thalli of $P$. Glemodiniamum. Dangeard, '88, '89.

Figs. 171, 172. \%oosporangia of same. Dangeard, l.c.

Fig. 173. Emergence of zoospore to form a mass at the mouth of the exit papilla. P. Glenodiniunim, Dangeard, l.c.

Fig. 174. Heterocont zoospores, P. Glenodiniamum, Dangeard, l.c.

Fig. 175. Zoosporangia of $P$. Sphueritue in a smooth resting spore of Sphaerita e'udogena. Dangeard, l.c.

Figs. 176, 177. Heterocont zoospores with a large refractive globule. $P$. Sphucritue, Dangeard, l.c.

Fig. 178. Empty sporangium in a spiny cyst. $P$. Sphaeritue, Dangeard, l.c.

Fig. 179. Spiny sporangium or possibly a parthenogenetic resting spore of Pseudolpidinm sp., from the elcmentary tract of the boll weevil. Kratka and Miller, $" 26$.

\section{P. deformens}

(All figures after Serbinow, '07)

Fig. 180. Infection of hair cell of Draparnaldia glomerati.

Fig. 181. Amocbae of $P$. deformans in threc hypertrophied cclls.

Fig. 182. Amocba with long pseuckspods.

Fig. 183. Division of amoeba.

Fig. 184. Fixed and stained preparation of trimeleate amoeba; zoospores case and infection tube attached to host cell.

Fig. 185. Similar preparation of a host cell with cleven rounded amoebae.

Fig. 186. Hypertrophied eell with six thalli.

Fig. 187. Mature zoosporangia with zoospores.

Fig. 188. Emergenec of zoospores.

Figs. 189, 190. Biflagellate zoos]rores. 
1'LA'TH: $1: 3$
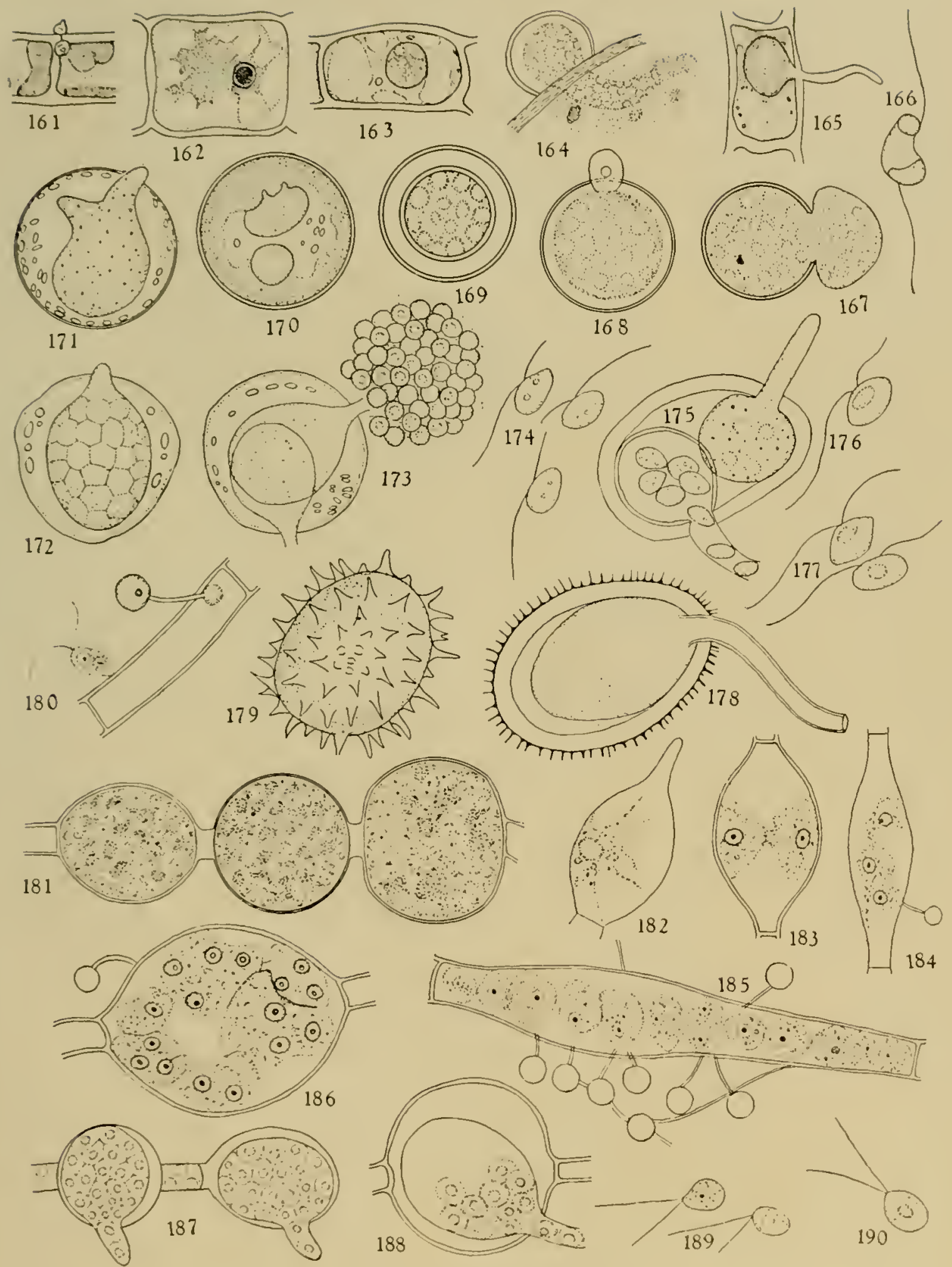

Olpidiopsis, Pseudolpidium 
(?), shorter flagellum extended forward in swimming; energing singly and fully developed and swimming directly away, or lying quiescent in a globular mass for a few moments at the mouth of the exit tube. Resting spores unknown.

The history of this genus has loeen discussed in relation to Olpidiopsis and need not be repeated here. As noted previously it is retained only as a temporary expedient for three species with biflagellate zoospores in which no resting spores have yet been reported. It is not improbalule as McLarty and Shanor have suggested that two of the species will eventually he included in Olpidiopsis, while the third one may possibly prove to be related to Rozellopsis or Woronina.

Zoospore germinating and infection of the host have heen described only for $\boldsymbol{I}$. deformans, so that an account of the early developmental stages must he hased on this species. As is shown in figure 180 the zoospores come to rest on the host, round up, encyst, and later develop conspicuous germ tubes (figs. 185, 186) which penetrate the lost wall. As in Olpidiopsis the content of the spore passes through this tube into the loost as a naked body, and in all species except $P$. deformans gives rise to one thallus or sporangium. At first the young parasite is more or less indistinguisluable from the host protoplasm, but as the latter is killed and partly consumed the parasite may be readily recognized as a small dense mass in the hypertrophied cells (fig. 181).

In $I$. deformans the thallus becomes amoeboid shortly after entering the host cell (fig. 24). It develops numerous long, fine (fig. 182) or blunt pseudopods (fig. 18.t) and creeps around in the infected cell. After its nucleus has divided it constricts and divides as is shown in figure 183. Serbinow's figures further suggest that the large multinucleate amoehoid thalli also may divide. so that numerous thalli result from a single infection. Whether or not several meronts are formed by a process of schizogony as in the Plasmodiopliorales is not certain. Multiple infection, lowever. is not uncommon (figs. 185, 186), so that the presence of several thalli in one cell does not mean that they have arisen from a single infection. The occurrence of single sporangia in a host cell (figs. 187,188 ) suggests that the amoeboid thallus does not always divide and that a zooppore may sometimes give rise directly to one sporangium. The early developmental stages of 1 . deformans are nonetheless suggestive of those of the septigeneous species of Rozellopsis, provided the reports that the thallus of this genus undergoes $\mathrm{di}$ vision are true. Minden was accordingly of the opinion that Serhinow's fungus is closely related to genera which develop sporangiosori. Únlike Horonina polycystis and species of Rozellopsis, the thallus of r. deformans is usually distinguishable from the host protoplasm, and no cross walls separate the respective segrments of the thallus as in $R$. septigena and $R$. simulans. It differs further from other species of Pseudolpidium hy the lack of oily or fatty refringent material in the developing thalli and sporangia, according to Serbinow.

P. GLENODINIANUM (Dangeard) Fischer, 189? Rabenh. Krypt'fl. 1, 4: 36 .

Olpidium Glenodiniumum Dangeard, 188?. Jour, de Bot. ?: 130. Pl. 5, figs. 6-10.

Zoosporangia solitary or up to 4 in a cell, spluerieal or ellipsoid, size unknown; lyyaline and smooth with a short papillae or exit tube which extends slightly beyond the surface of the host. Zoospores emerging fully formed and remaining quiescent for a few minutes in a glohular mass at the mouth of the exit orifice hefore swimming away; spherical at first. later becoming oval or ellipsoid, size unknown; flagella laterally inserted, shorter flagellum extending forward ass longer one projecting backward in swimming. Resting spores unknown.

Parasitic in Glenodinium cinctum in France. completely killing and destroying flourishing cultures.

According to Dangeard this species had been frequently observed before his time, hut its thallus and zoospores were mistaken for germination stages of the hosts as well as those of Ceratinm fuscus and $C$. tripos.

P. SPHAERITAE (Dang.) Fischer, I.c., p. 36.

Olpidium Sphecrilue Dangeard, 1889. Le Bot. 1:51. PI. 3, figs. 3- .

Olpidiopsis Spluterifue (Dang.) Schroeter, 1897. Engler und Prantl, Nat. Ptlanz.f. 1, 1: 69.

Zoosporangia solitary or up to 6 in one host cell, hyaline, smootls, spherical. or ellipsoid, size unknown, with a single exit canal which projects far beyond the surface of the host cell. Zoospores small. size unknown, hyaline with one to several refractive granules; flagella laterally ( $)$ inserted. shorter one extending forward in swimming. Resting spores unknown.

Parasitic in the resting spores of Sphaerita endogena in France.

This species has not heen reported since 1889 and nothing further is known ahout its life history and structure besides the original description of Dangeard.

P. DEFORMANS Serbinow, 190\%. Scripta Bot. Ilort. 1mp. Unir. Petrop. 24: 25, 15t. Pl. 1, figs. 1-12; pl. 4, figs. 16-28.

Thallus more or less naked, amoeboid. eonstricting and dividing to form additional thalli. Zoosporangia solitary or up to 11 in a host cell. hyaline. smooth, spherical, $35 \mu$, or elongate and ellipsoid, $14.7-27 \mu$ $X+7.5 \mu$ with a broad elongate. $8 \times 15.8 \mu$, exit tuhe which projects considerably heyond the surface of the host cell. Zoospores. hyaline, spherical or oval, 3.15-1.75 $\mu$, often changing shape; flagella laterally inserted; emerging singly. fully developed and swimming directly away. Resting spores unknown. 
Jaravitio in Draparnaldia glomerata in Russia, causing markind liypertropley of the loust cells.

The above dencription is taken from a German résume of the Runsiau text. Becianse the thallus of l'. deformans is amochoid and molergoes division into secondary thalli. Serlinow was meertain alsout the taxmomice position of this spereics. and he aceordingly assierned it muly temporarily to l'seuldpilium.

Anotluer guestionable and midentitied species of l'seudalpidium was found hy Kralka and Miller ('26) in the alimentary tract of the boll weevil iu Ceorria.'Tluse workers did not sturly its life cyclo and inerely reported and figured a tew spiny oval.

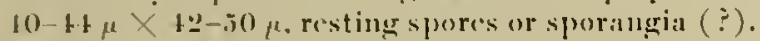
Whother these bodies are partlonogenetic resting spores or spiny zoosporangria of Pseudolpidium or relate to an entirely ditferent uranuism is not evident from Krafka and Miller's description.

Whether or mot the parasite which Niagler ('11) found in linglena sanguinea and described as P'seudosphaerita Fuglenae belongs here is questionahle. The prencence of long exit tulbes secmus to exelude it from P'sendosphaerita so far as this genus is now known, and the zoovporangin are sugerestive of those of Olpidiopsis and Pseudolpidiam. However. unt il the zoospores have heen olserved the identity of Vaggler's fungus will remain doulotful.

\section{PSEUDOSPHAERITA}

\section{Dingearl, 1895. I.e Bot. $4: 243$.}

\section{(PLATE: JH)}

Thalli intramatrical. solitary or up to 25 in a cell. a) plearing to le more or less naked lout immiscilhte with the luont protoplasm when young: becoming invested with a detinite wall or memlurane as they mature: wral, sphurical. eoiled. elongate. or slightly irregular. Zoosporangia of same shape and size as the mature thalli : (xit papillate apparently lacking; opening hy a rupture ( $\vdots$ ) of the wall. Koospores heterocont or isocont ( $\vdots$ ) with flagella inserted near the anterior end. short flagellum directed forward in swimning while the longer one is dragged along heljind: liberiated to the outside ( $\doteqdot)$ or inside the host eell where they may start secomdary infections. Resting spore unknowi.

This genme resemblen Sphaerita superficially lut according to Dangeard satest study ("3:3) differs fundamentally from the latter gemus by the division or segmentation of its thallus after tach suceessive mitosis (figs. (9-1.j), with tles result that multinureate thalli are rarely formed. The soments hecome progremively smaller witl eacle division and are eventually tramsormed directly into zouspores (fig. 17). D)ingeard, nevertheless. figured multinucleate thalli both in 1895 (fig. 3) and 1933 ( fig. 8). whel sngerented to him that he may have had two organisms at liand or that I'seudaspharita has two extreme tyjes of development with intermediat. atages between. In his lattror cont ribution, Danguard held to the former possibility, while . Mitchell (" 28$)$ upheld the scoond viewpoint. 'lhe latter worker roported that the parasite which he fonded in buglena eaudata segments aller told nuclear division (tigs. 19-22). while the one oceurring in $\%$. riridis de:velops a multinucleate thallus and finally undergroes cleavige into sport rudiments (figs. 23-27). Acoording to his aceoment these are hut dillinent stage's of the same parasite. However, the identity of Miteledl's speedes is uncertain because he did not doserve the zoospores nor the number, rolative lengtlis and position of the Hagella. 'The similarity in types of development monetheless suggests that his species are tlee same orginisms studied by d)angeard in 1895 and 19333 , and for this reason tiey are included ju Plate 1 f. Jahn ( 333 ) maintaned that the species with the multinucleate "plasmorlial" stage (figs. 23-27) is Spharita dangeardii Chatton and Brodsky. 1909. Obviously, more intensive study of botl Spliaerita and P'sewdosphaerila is necessary before the latter gemus can be adequatedy dianumsid and discussed in relation to otleer gencera with hiflagellate zoos jures.

Dangeard and Ilitelell did not olserve infection of the host. so that it is not known whether the zos)spores enter the Euglena cell direetly or germinate on its surface and then leave the cmipty spore ('ale and penetration tube behind as in Oppliopsis, liurychasma, ete. In instances where the zoospores are discharged within the host cell (fig. 18) they apparently develop directly into thalli ( $(j-8)$. As noted above. Dangeard figured scveral multinucleate thalli which appear to be underguing cleavage (figs. 1, .5), but this appearance is due to the complete or partial disappearance of the lines of demarkation of the: zoospores in the late stages of development, acourding to Bangeard's latest accomut. As a result the mature thallus may appear to be homogreneous and multimueleate (figs. 3, 16) or divjoled into large irregular multinuclear segments (figs. 1, 51). "The type of cytokinesis suggested by the latter two figures appears to be quite different from that illustrated in figures 10 to 1 t and 1 !) to 2.2. Here the whole thallus appears to be partitioned or franmented after each mitosis, while in figures $5,5$. and 27 it looks as if the content of a sporangium has umdergone endogenons division witl the original thallus wall remaining jntact.

'The method hy which the zoospores get ont of the:

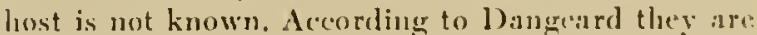
liherated within the lost. hut it is olvious that somen of them eventmally escolpe. Otherwine alditional lusts would not become infected. Mitchell sugagested that they might coscape through the "montly" valuole or liy rupture of the loust rell. The mature free swimming zoospores are pyriform aud pointed at the apex with two unegual Hagrella inserted a short distance hack of tla anterior cud (tig. 1). 'lheir mowement in swimming is more even. straight forward and less irregular and darting than in Siphaerita. 
According to Dangeard, the structure and activity of Euglena polymorpha are not greatly affected at first hy the presence of the parasite, and in exceptional cases of monoinfection this host may continue its nornal activities even after the parasite is mature. The plastids may remain green and unchanged, except for a reduction in size, np to the time of sporulation (figs. 16, 17). In instances of heavy infection, however, the injurious effects may appear sooner. As the parasites develop and mature the starch grains become corroded, the chloroplasts turn lighter in color, and the cytoplasm becomes reduced in quantity. The vacuome, stigma, and nucleus, on the other hand, remain normal for a louger time. The initial effect on the nucleus is an increase in chromaticity as densely stainable rods and fragments appear in the reticulum. Later the nucleus decreases in size and finally disintegrates. Like the remainder of the host cell it does not enlarge or divide becanse of the presence of the parasite. Nitchell also reported that the parasite bas no toxic effect on $E$. caudata. No differences in activity could be detected in infected individuals, although some of them were so crowded with parasites that little or no green color was visible. In $E$. viridis, on the other hand, infected specimens were nearly always rounded, and in fixed and stained preparations early degeneration of the uncleus and chromatophores was evident in such individuals. In the late stages of development the parasite was often envoloped by a mass of degenerating cytoplasm. including traces of the liost nucleus and plastids.

$P$ sendosphaerita includes at present $P$. Euglenae and possibly another species, $P$. radiat a conb. nov. However, the reports of Pumaly ('27) and Ce.jp ('35) that Sphaerita endogena and $S$. dangeardii have biflagellate zoospores suggest that additional species exit. It is equally possible that Sphaerita may have biflagellate zoospores and does not differ fundamentally from l'seudosphaerita. The parasite of $E$. sanguinea described by Nägler ('11) as $P$ '. Euglenae probahly does not relate to this species because it develops long exit tubes like Pseudol pidium Sphaeritae. The taxonomic position of Pseudosphaerita and its relation to other genera with biflagellate zoospores is very uncertain at present. Dangeard (95) first regarded it as a member of simple olpidiaceous chytrids elosely related to Splaerita, hut in 1933 he created a separate family, Psendosphaeritaceae, for it among the Arehinyctes because of its characteristic type of development. Mitchell included the species which he studied in the Sporozoa under the Haplosporidia.

P. EUGLENAE Dangeard, 1895. l.c., fig. 9. 1933, ihid. 25: 36. Pl. 4, figs. 3-16.

Zoosporangia solitary or numerous, oval, spherical. elongate, coiled, or slightly irregular, hyaline and smooth, forming 64 to 128 zoospores. Zoospores pyriform, $2.5-3 \mu \times 6 \mu$; flagella 2.5 and $7 \mu$ long respectively. For further details see the generic description above.
Parasitic in Euglena viridis and E. polymorpha in Franee (Dangeard, l.c.); E. caudala in Georgia, U. S. A. (Mitchell, l.e.).

This species is possibly the parasite with pyriform biflagellate zoospores which Stein (1878. Abt. III, 1. Pl. 20, fig. 21) figured in F. ziridis in Germany. He also illustrated parasites with biflagellate zoospores in Chlamydomonas alboriridis (P. ] t, figs. V1 t-14) and C. pulvisculus (Pl. 15, fig. 36), but since the flagella are posteriorly attached it is doubtful that these parasites relate to l'seudosphaerita.

P. RADIATA (Dangeard) comh. nov.

Sphaerita rutiuta Dangeard, 1890. Le 13ot. 2: 5.t. P1. \&, fig. 20 .

Zoosporangia solitary or up to 3 in a cell, liyaline, smooth, oval and egg-shaped, size unknown; liberated or expelled to the outside by the rupture of the host cell. Zoospores hyaline with a refractive globule, oval and elongate, isocont (?), size nnknown; liherated by the breakdown of the sporanginm wall. Resting spore unknown.

\section{PLATE I.t}

(Figs. 2-5 after Dangeard, 95; figs. 1, 6-8 after Dangeard, '33; figs. $28-31$ after Dangeard, '90; figs. 19-27 after Mitchell, :28.)

\section{Psendosphaerita Euglenue}

Fig. 1. Biflagellate heterocont zoospores with flagella inserted in a small depression near the anterior end; shorter flagellum directed forward.

Fig. 2. Uninucleate oval parasite (Sphaerita sp. ?) in E. viridis.

Fig. 3. Ifultinucleate coiled thallus.

Fig. 4. Cleavage stages (?) of multinucleate thalli.

Fig. 5. Euglena polymorpha with 17 uninucleate parasites which have applarently developed from zoospores liheratod within the host celi.

Fig. 6. Uninucleate parasites slightly larger.

Figs. 7,8 . Uni- and multinucleate parasite's.

Figs. 9-15. Stages in the division of the parasites following cach mitosis.

Fig. 16. A multinucleate parasite shortly before sporogenesis.

Fig. 17. Sporangium with fusiform zoospores.

Fig. 18. Zoospores liberated within host cell.

Fig. 19. Euglena cuudutu with one uninucleate thallus.

Figs. 20-22. Successive stages of growth and division of the thallus into spores in $E$. crudatr.

Fig. 23. Two uninucleate thalli (sphueritu dengendii ?) in $\mathbf{E}$. viridis.

Fig. 21-26. Stages in the development of a multinucleate tluallus in $E$. viridis.

Fig. 27. Sprorangium fillect with spherical and oval sprores.

$$
\text { Pscudosphaeritu (?) rudiate }
$$

Figs. 28, 29. 13iflagellate iso- and heterocont and uniflagellate zouspores.

Fig. 30. Cryptomoness orvele with two small parasites.

Fig. 3t. Cryptomonas oveta with a large parasite in which the refractive globules are radially oriented. 
PIATl: 14

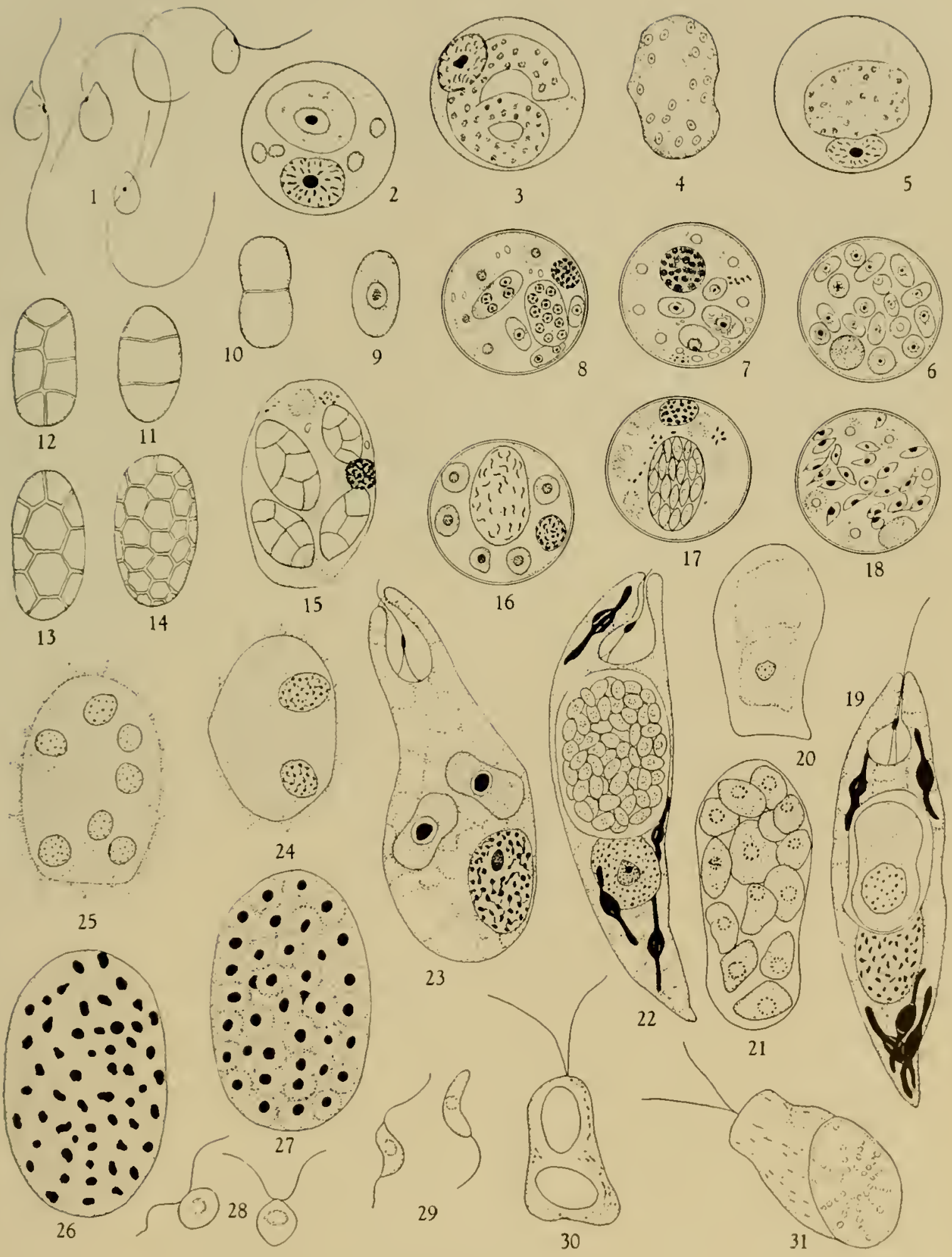

Pseudosphaerita 
Parasitic in Cryptomonas ozata in France.

This species was apparently observed by Dangeard in 1889 (Pl. 1, fig. 15) and mistaken for the endogenons germs of the host. Its outstanding charaeteristie, according to Dangeard (90), is the radial orientation of the refractive globules in the thallus (fig. 31). The inclusion of this speeies in Pseudosphaerita is obviously questionable, beeause the thallus is expelled from the host as in species of Sphaerita. Although Dangeard figured most of the zoospores as biflagellate he failed to include this species in Pseudosphaerita. Nevertheless, it is included here tentatively althongh nothing is known about the development of the thallus and the type of cytokinesis.

The oval and elongate "muclei" which Stein ( 1878, pl. 19, figs. 29, 31) figured in the same lost may possibly relate to this species, although no radially oriented refractive globules are shown.

\section{BLASTULIDIOPSIS}

\author{
Sigot, 1931. C. R. Soe. Biol. 108 : 37. \\ (PLATE ] 7, FIGS, 10-12)
}

Thallus intramatrical, unieellular. loled, plurilocular, irregular, and holocarpic. Zoosporangia solitary in host cell, liyaline. smooth, irregular, lobed and plurilocular with a low exit papilla. Zoospores biflagellate and isocont, developing completely and swarming in the zoosporangium, swimming directly away after emerging. Resting sprores unknown.

The thallus of this monotypie genus in very similar in appearance to that of Blastulidinm, lint the type of infection and thallus development are more like those of species of the family Lagenidiacear. 'The zoospore comes to rest on the ('yclops egg and forms a germ tube whieh penetrates the host wall. The eontent of the spore does not prass into the host eell as a more or less naked protoplast as in Olpidiopsis, Ectrogella, ete.. but instead the tip of the penetration tube enlarges, elongates, branches and eventually forms the irregular lobed thallus. Sigot did not observe germination. infection and the stages of thallus development in living material, but hased his account on studies of fixed and stained preparations. In the early stages of derelopment, the thallus contains numerous small vacuoles (fig. 10) which later fuse to form a large eentral one. 13y this time the contents of the host cell have heen largely consumed, and the parasite usually occupies the entire (avity. After the racuoles have fused, the more viscid, visible part of the protoplasm forms a thin parietal layer in which the muclei lie (fig. 11 ). Cytokinesis is apparently accomplished by centrifugal cleavage furrows which cut out unimedeate spore rudiments. 'The latter develop, into zoospores which soon begin to swarm within the sporangium. Shortly thereafter the tip of the exit papillit deliquesces, and the zoospores swim out and away. No evidence of diplanetism has so far been olserved. As is shown in figure 12, the zoospores are oval and slightly elongate with two flagella inserted near the anterior end at which lies a conspicuous refractive globule, similar to that described by Sparrow ('31, '36) for the zoospores of Sirol pidium and Petersenia.

The taxonomic position and relationships of Blastulidiopsis are obscure, since nothing is known about its resting spores. As noted previously its type of development, according to Sigot, is suggestive of species of the Lagenidiaceae, while the appearanee of the centrally vacuolate sporangia, swarming of the zoospores within, etc, are similar to those of Olpidiopsis, Sirolpidium, Petersenia and other related genera.

\section{B. CHATTON1 Sigut, l.c.. figs. 1-3.}

Zoosporangia solitary, hyaline, smooth, irregular and lobed, size unknown. Zoospores $6 \times 8 \mu$ with a refractive glohule at the anterior end; flagella $t 5-$ $20 \mu$ long, inserted near the anterior end and extending in opposite directions. Resting spores unknown.

Parasitic in eggs of Cyclops in France, destroying their content but cansing no enlargement or division of the inflated cell.

\section{PYTHIELLA}

\section{Couch, 1935. Mycologia 27: 160.}

\section{(PLATE 15)}

Thallus intramatrical, holocarpic. oral, ellipsoid and spluerical; solitary or up to $t$ in a swelling. Zoosporangia centrally vacuolate with 1 to 5 simple or hranched exit tubes. Zoospores fully delimited in the zoosporangia, diplanetic; primary zoospores aflagellate, gliding ont and encysting at the tip of the exit tule; content of cysts emerging after about an hour: motile secondary zoospores ohlong with a longitu-

\section{PLATE 15}

\section{Pythiella cermalis}

Fig. 1. Germinated zoos]rore with young parasite within Pythium ligplata.

Fig. :. Be giuning of host hypertrophy.

Figs. 3-7, 9-13. Successive stages of the maturation of a thathus into a zoosporangium, eleavage, zoospore emission, cheystment, and emergence from eysts.

Fig. 8. "The so-ealled esealloped or "balked" stage of sporegenesis.

Fig. 9. 'The lomogeneous stage following elearage.

Figs. 1+16. Successive stages of emergence of the zoospore from a cyst.

Fig. 17. A mature hiflagellate isoeont zoospore.

Figs. 1s, 19. Young antleridia anel oogonia in hyphal swellings.

Figs. 20, 21. Beginning and completion of plasmogamy.

Fig. 2.2. An chg fertilized by two antheridia.

Fig. Mature oospore within an oogonium and an (mpty attachet antheridiunt. 
PIATE 15

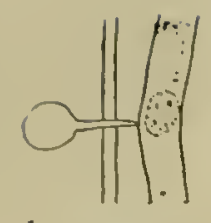

1
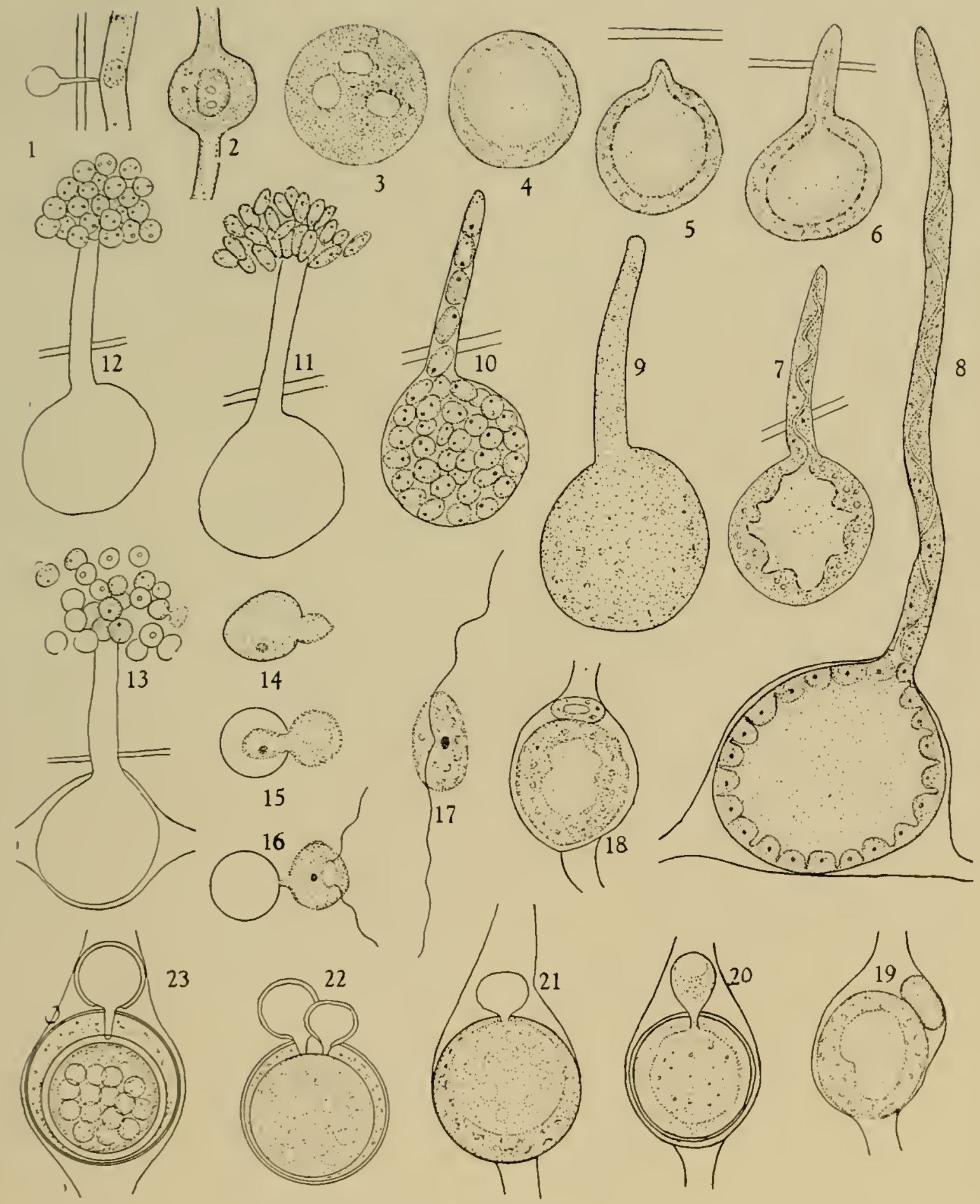

Pythiella 


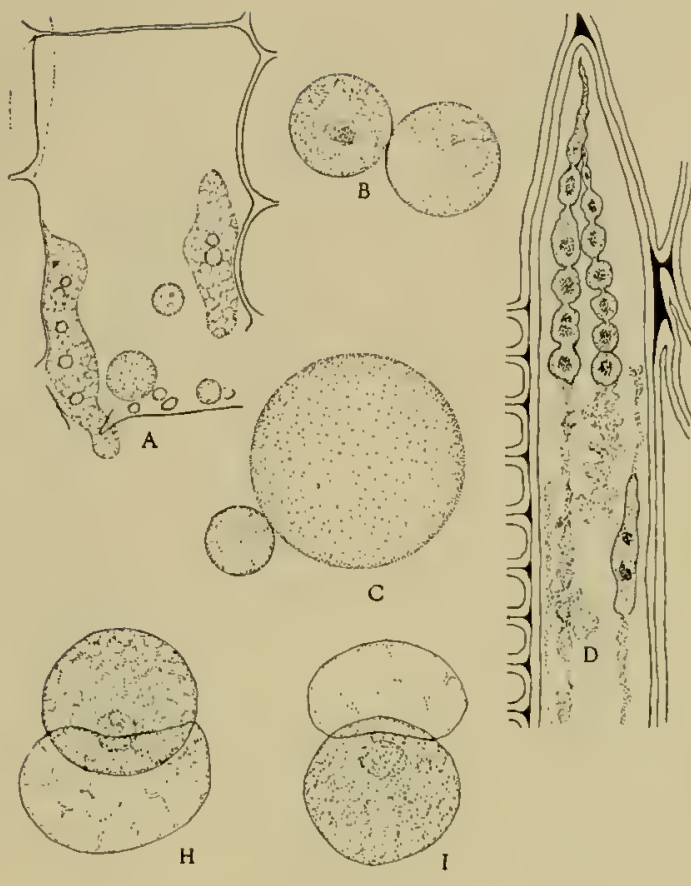

Carpenterella $s p .(?)$

Text-fig. A. Amoeboid thalli and spherical bodies in sugar cane. Drawn from plotograpls $5 B$ after Carpenter, 40.

Text-fig. B. Two almost equal, paired spherical bodies. Drawn from photograph 7, left, after Carpenter, ' 40.

Text-fig. C. Association of a large and a small sphere. Drawn from photograph 7 , right, after Carpenter, ' 40.

\section{Crerpenterella Molinea \\ (AII figures after 'Tehon and llarris)}

Text-fig. D. "Thalli in fiber cell showing plasmodial enlargements and head-like knots."

Text-fig. E. "Thallus in ray and wood parenchyma cells, showing eonnections through pits."

Text-fig. F. "Net-like thallus in parenchyma cell, sending plasmic projections into an adjoining trachea through half bordered pits."

Text-figs. ( $i$ to 1 . "Stinges in the formation of the oospore, showing shrinkage of the male cell to form the companion cell of the oospore."

Text-fig. M. "Mature oospore with dense alveolar cytoplasm, granules, heavy wall, and companion cell,"

dinal groove, laterilly biflagellate and isocont, one flagellum directed forward, the other backward in swimming; swimming movement slow in a spiral path, zoospores rotating on their axes. Oospores formed by the fusion of the contents of one or more small thalli (antheridia ?) and an egg cell (?) lying within a rudimentary (?) oogonium; fusion canal fine and delicate; male thalli remaining attached to the oogonium as empty hyaline vesicles or companion cells; germination unknown.

This genus includes a single species, $P$. vernalis, which combines in its life cycle many of the characters of the Olpidiopsidaceae, Lagenidiaceae,

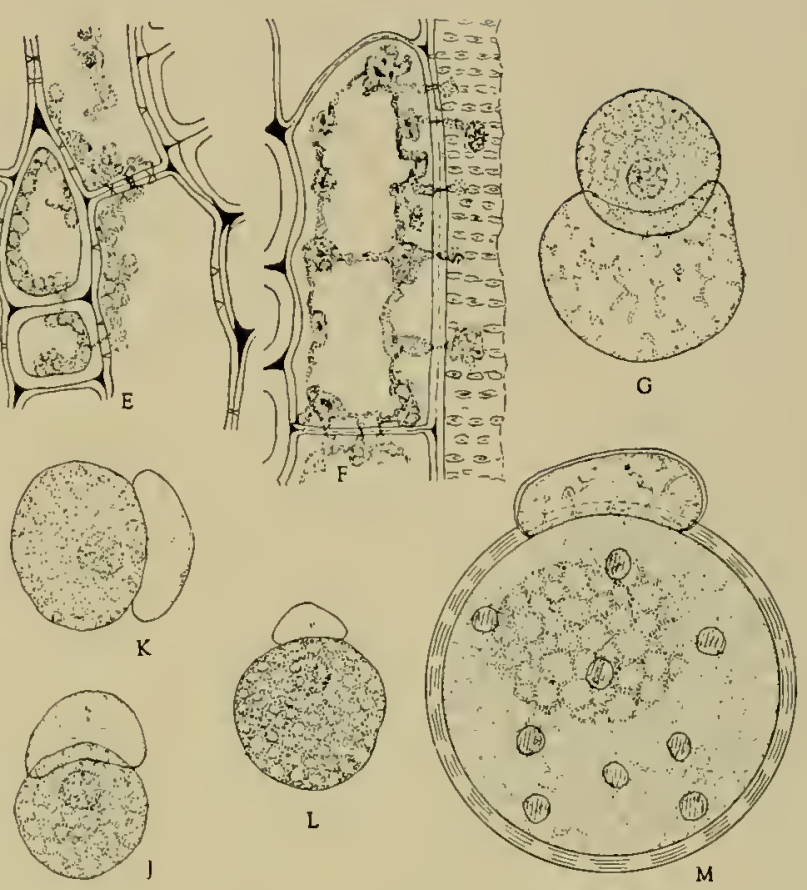

Saprolegniaceae, and Pythiaceae. It is strikingly similar to Ectrogella, A phanomycopsis, Achlya and Saprolegnia in the method of formation and hehavior of the zoospores, Int differs from these genera, according to Couch, by the appearance of its protoplasm which has a pale whitish fatty gleam like that of Lagenidium, Myzocytinm, Olpidiopsis, ete. In type of sexual reproduction it resembles to some degree Olpidiopsis schenliana, but differs from this speeies by the presence of periplasm in the oogonium. By the latter character it resembles species of Pythium.

Pythiella vernalis parasitized Pythinm gracile and $P$. dictyosporum which in turn are parasitic in species of Spirogyra. As is shown in figure 1 the zoospore of $P$. vernalis comes to rest on the Spirogyra filament, encysts, and then develops a fairly long germ tube which penetrates the algal cell until it reaches the Pythinm hyphae within. The latter is then pierced, and the content of the zoospores passes into the liost cell as a more or less naked globule of protoplasm (fig. 1), like that of Olpidiopsis, Ectrogella, etc. The zoospore case and penetration tube remain hehind and persist for a long time after infection. The young parasite assumes a spherical or oval shape in the P'ythinm hyphae (fig. 2), but it is not certain that it possesses a well-defined wall in the early stages of development. Couch believed that it may he enveloped by a membrane at this stage, but his figures do not show it. No evidence of amoeloid movement or migration of the young parasite has been observed. As the thallus develops, the host hyphae enlarge in the region of infection so that broadly oval, spindle-shaped and spherical swellings or galls are produced (figs. 2, 13, 18-23). However, the host does not form cross septa and delimit 
the parasite as in eascs of infection hy species of lozella. 'The young thallus usually includes a large mumber of small rienoles (fig. 3) and as it hecomes larger these increasce in si\%e al oo and eventually fuse to form a larese eentral vacuble (tig. +). As in the sporangia of Siaprolegnia specedes. this valcuole may cxtend in thromgle the center of the exit tule and often follows a spiral patl (figs. $\tau . s$ ). "lowe wall of the thallus and sporangia is well defined at maturity. but. unlike tlat of Olpidiopsis and other similir fungi. does not slow il marked cellulose reaction when tested with clolorn-iodide of zinc. 'The exit tuhes may be simple or loranched and vary from ] to 5 per sporangium. They are uswally quite long and cxtend not only be rond the host cell but through the wall of the spirogyra filament and far beyond its surface.

'The central racuole increases in size as the sporangia mature until tle remainder of the protoplasm forms a romparatively thin parictal layer (figs. + s). "The horder of the vacuole hecomes quite irregular as loroad cleavage furrows arc formed (fig. $\tau$ ) which progress centrifugally towards the periplicry. Just hefore these furrows reach the plasma memhrane the parictal layer of protoplasm has a characteristic scalloped aplearance (fig. 8) wlicll corresponds to the so-called spore initial stage in the siprolegniaceac and the "balling" stage described hy Schertiel ("․5) for Ectrogella and A phanomycopsis. As the rearage furrows attain the periphery the central vacuole collapses and disappears. The houndaries of the cleavage segments become quite invisible and the protoplasm appears to oc(up) the entire volume of the sporangium (fig. !). The latter decreases slightly in size at this stage. due possib!y to loss of water during the collapse of the central racuole. This stage is strikingly similar to the soalled homogenous plase of sporogenesis in Olpidiopsis, Eictrogella, and the Saprolegniaceae. Fery hortly afterwards the fully formed sporcs become visible (fig. 10) and soon ghlide out of the sporangium as the tip of the exit tule ruptures (fig. 11). "They are first ellipticial in slape and contain two or more conspicuous eramules. but soon round up) and encyst and thus form a cluster around the tip of the exit canal (fig. 12) as in Ichlya and sprecies of Lagenidium, Ectrogella, Iphanomycopsis, ete. Within all lour or two the content of the cyst emerges (figs. 13-16) and is transformed into an oblong biflagr.llate isocont zoospore (fig. 17) which soon swims away.

Sesual reproduction in l'. zernalis is hotorognmous. "The so-ralled antheridim and oogoninm are quite uncqual in size amd lice in the same gall or swelling (fie. 18). "The antheridium shows no structural differentiation as a gametangim. and it is accordingly questionahle whether or mot it slonld he designated as an antheridium in the original sense of the. term. I'lic oogonium, on the otlier liand. contains at large central vacuole and parietal laver of protoplasm whicls appear to undergo some decrrece of differentiation into ooplasm and periplasm. according to Conchis description. 'I'he antleridiun forms a fiuc: fusion eanal which penetrates the wall of the oogonium into the onplasm (figs. 20,21 ). The content of the antheridium therehy flows into the ooplasm and fuse's with it. As the gregote matures it forme a fairly. thick wall, while most if not all of the periplasm gradually disappears (fig. 23). O(rasiomally two antheridia may fertilize one ega cell (fig. "2.3) as in spereses of Olpjoliopsis.

Sothing is known concerning the origin of tha respective gametes in this genus. Whether the thalli whele arelop into the antheridium and oogonium respectively are derived from zoospores from the same or different zoosporangia is not known. It is accordingly impossille to say at present whetlecr sex differentiation is genotyoic or phenotypic. linrthermore, it remains to be seen whetler the gametes are multinucleate and their nuclei fuse in pairs or all hut one nucleus in each gamete degenerate before karyogamy occurs.

\section{P. VERNALIS Couch, l.c., figs, 1-97.}

Zoovporangia solitary or up to f in a swelling. spherical or subsplucrical. $10-30 \mu$, sumctimes flattened when several occur in a gall; exit tubes up to $50 \mu$ long by $+\mu$ in diameter. Notile zoospores 3.7+ $\mu$ in diameter. Oogonia spluerical or subsplerical. $11-18.5 \mu$. Antheridia livaline, smooth, slightly flattened or splerical. $5 \mu$. Oospore spherical. $9-15 \mu$. hyaline, smooth and thick-walled.

Parasitic in ''ythium gracile and I'. dictyos porum in Nortl, Carolina, U. S. A.

In comnection with the Olpicliopsidaceac lorief mention may be made of two mnusual and incompletely known parasites which Carpenter ('10), and 'Tehon and Harris ('H) described as forming oospores in somewhat the same mamer as Olpidiopsis. However, in referring to them here the antloor does not imply that they should he included in the Opidiopsidaceate as this family is now recognized, hecause their thalli are amoeboid and plasmodimmlike, and zoospore are not definitely known to oceur. 'The first of these fungi was reported by Carpenter to be associated with chlorotic streak disense of sugar cane in Ilawaii. 'l wo levelopmental phases of the barisite were olserved, but the connection luttween them was not definitely estalblisheel by Carpenter. 'I'lue first plase comsists of a naked amoelonid or plasmolimm-like thallus (text-fig. A) suggrestive of that of the l'lasmodioplorales and Woroninaceac. However, no individual movenent of the thallus or streaming of the protoplasm was observed, nor does the parasite calise cell stimulation or hypertrophy of the lost tissues. 'The second and most conspicums phase comsists of splacres of protoplasm which oceur in the parenchyma of the stalk and vary from $5-60 \mu$ in dianceter and hyaline to gray. brow or black and (op)acpuc in color. Tle hyoline splueres. 3-2.5 $\mu$. may have thick walls and rosemble livpuospores which, aceording to Carpenter. "appurar to lue formed lig copmlation of two units, the content of one spluere 
entering the other to form lyypnospores, while the empty sphere may remain as a companion eell." (Text-figs. B. C.) Carpenter was uneertain of the identity and relationships of his fungus. Nonetheless, he referred to it as a clytrid and frequently compared it with Physoderma maydis.

The second of these fungi was reported by Tehon and Harris as inlabiting the xylem of a diseased Moline elm from Wisconsin. It is very sinilar to the speeies found by Carpenter, and they aecordingly named it Carpenterella Molinea. Its vegetative thallus may appear in two slightly different forms, one elongate, attenuate and thread-like with few to many enlargements (text-fig. D), the other amorphie and amoehie in appearance (text-fig. F). This vegetative phase oecurs in wood parenchyma, wood fiber, and ray cells lut not in trachae. The thallus may he eonfined to one cell or extend through pits in the walls to adjoining cells (text-fig. F). The thalli figured by Tehon and Harris are somewhat suggestive of the psendo-plasmodium of Labyrinthula, but the bead-like enlargements are not as distinctively spindle-shaped and cellular as those of the latter genus. No zoosporangia have heen found in C. Molinea, hut the oecurrenee of zoospores is suggested "ly the presence in some host trachate of numbers of minute, mononueleate, rounded plasmodium-like bodies, some few of whieh seem to possess a single polar eilium," aceording to Tehon and Harris. They have not, however, ohserved motile flagellate eells.

The origin of the so-called male and female thalli which are reported to fuse is not elear and eertain. but Tehon and Harris helieved that the swollen ends of strands of the thallus which projeet into the trachae (text-fig. F) breome detaehed and assmme a spherical shape. These splueres later luecome associated in pairs, and as the staining reaction of one of them inereases in intensity the other sphere beeomes more lyaline and empty and deereases in size (textfigs. G-I.). 'This shrinkage was interpreted ly Tehon and Harris to mean that the protoplasm of one sphere had flowed into the other, and they aecordingly designated the two thalli as male and female. 'They reported that the fusing thalli are equal in size, Init text-fig. G shows clearly that the male eell may he eonsiderably larger than the female. The mature resting spore or oospore is spherical, $10 \mu$, with dense opaque protoplasm and nmmerous refractive globules, smooth, thiek-walled, and aecompanied by a small hemispherical or lunate companion cell (text-fig. M). Germination of these spores has not heen observed.

Tehon and Harris regarded their fungus as a chytrid but were not certain ahout its taxonomie position. They believed that the elaraeter of the thallus and the presenee of a vesiele or eompanion cell on the resting spore indieate relationships witl the Woroninaceae (interpreted in the sense of Minden) or the Olpidiaceat. They aceordingly placed C. Molinea and Carpenter's fungus in the latter family near Pseudolpidiopsis. This disposition is obviously untenable because Pseudolpidiopsis is synonymous with Olpidiopsis and belongs in the OIjpidiopsidaceae. Whether or not these fungi belong in the last named family will not he eertain until the presence or absence of zoosporangia and zoospores has been demonstrated. The method of resting spore formation is nevertheless very similar to that of many species of the Olpidiopsidaceae, while the amoehie, plasmodium-like vegetative thallus suggests some relationship to or a parallelism in development with the Plasmodiophorales and the family Woroninaceae as these groups have been interpreted ly the author. While the origin and phylogeny and relationships of Carpenterella are not elear, it is nevertheless a signifieant genus and serves to emplasize again that there may be many more simple fungi to be found, the discovery of which will doulstless ehange many of our present-day coneepts eoneerning the Phyeonyeetes.

\section{BIBLIOGRAPHY: OLPIDIOPSIDACEAE}

Atkinson, G. F. 1909. Ann. Myeol. $7: 4$.

Behla, R. 1903. Die Pflanzenparasitire des Krehses. Berlin.

Butler, E. J., and G. R. Bisby. 1931. The Fungi of India. Caleutta.

Carpenter, C. W'. 1940. The Hawaiian Planter's Record $49: 19$.

Ceju, K. 1935. Spisy vyd. Priridov. Fakul. Karlovy Univ. P'rahall, Ali, $i$.

Chatton, E., and A. Brodsky, 1909. Arch. Protistk. 17: 1.

Cienkowski, L. 185.5. Bot. Zeit. 13:801.

Couch, J. N. I941. Amer. Jour. Bot. $98: 704$.

Dangeard, P. A. 18s9. J e Bot. 1: 1. 1890, jbid. 2: 63.

Davis, J. J. I914. Trans. Wise. Acad. Sei., Arts, Letters. 2): 846 .

Diehl, H. 1935. \%entralhl. Bakt. Parasit. II, 9:2 229.

Fischer, A. 1880. Bot. '\%(it. 38: 689. 188?. Jahrh. wiss. Bot. 13: 986.

Graff, P. W. 1928. Mycolugia $20: 158$.

Gilman, J. C., and W. A. Areler. 1939. lowa Jour. Sci. 3: 299 .

Harvey, J. V. 19:2 T. 'Trans. Wisc. Acad. Sci., Arts, letters $23: 551$.

… 194?. Jomr. Elisha Mitchell Sci. Soc. 58: 39.

Jalın, '1'. L. 1933. Arch. Protistk. 79: 349.

Karling, J. S. 1939. Alstracts, Third Int. Cong. for Microbiol. 13. 2.25.

Krafka, J., and J. E. Miller. 19:6;. Ann. Entomol. Soe of America 19: 464 .

Maneval, W. E. 1937. Univ, of Missomri Sundies 12, 3.

Matthuws, V. D. 193.). Jour. Elisha Mitchell Sci. Suc. $51: 306$.

Melarly, D. A. 1939a. Alstracts, Third Int. Cong. for Microbiol. p. 226.

- 1939h. Amer. Jour. Bot. 206: 194.

Mitchell, J. B. 1928. T'rans. Amer. Miero. Soe. $47: 29$.

Mull(cr, F. 1911. Jahri). wiss. 13ot. $19: 421$.

Nigreli, C. 1844. Z.itsclur. wiss. Jot. 1, no. 3: 29.

Nägler, K. 1911. Arch. Protistk, $22: 262$.

Peteh, 'T'. 1940. 'The Naturalist No. 998:68.

Petersen. J1. E. 1903. Jour. de Bot. 17: 214.

Pringhleim, N. 1860. Jahrh, wiss. Bot. Q: 20.5.

Pumaly, A. 1927. Bull. Soc. Bot. France. 74: 47\%.

Reinsch, P’. I878, Jahr'). wiss. Jot. 11: 283. 


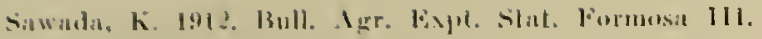
1919,1 , Iid. 19.

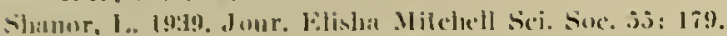
19) Ho, ilid. iti: leis.

sparrow, F. K. 1933. Mycologial 21: 3tis. 1933, ihid, 95:

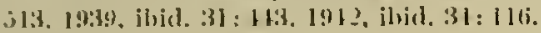

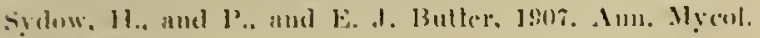
3: IN;.

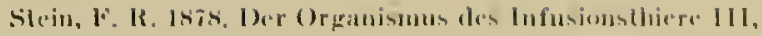
ahl, 1, 2. 1, c.iprig.

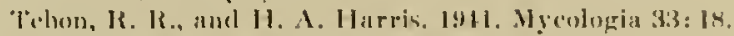

Valkanus, A. 19311. Areh. Prolislk. 73: 361.

Varilchak, 13. 1931. C. R. Aend. Sici. Jaris. 192: 37 I.

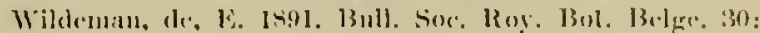
1 (i).

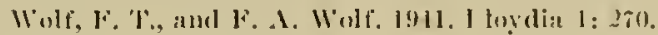

\section{('haty) I}

\section{Sirolpidiaceae}

Sparrow, 19+2. Mycologia 3t: 113.

Tuls rasule was established by Sparrow for the genera Sirolpidium and Pontisma which Petersen ("0.5) lrad previously made the hasis of the family. Holochytriaceac. 'Thirten rears earlier, however, Fisclier ("92) liad proposed the same family name as an alternate for the Aney listaceae to include $\boldsymbol{I}_{\mathbf{y}^{-}}$ zocytium, Achlyogeton, Lagendium and Ancylistes. 'The'e was thus no atrreement between Petersen and Fischer ats to which genera compriac the Holochytriaceae. hut the neverlheless placed it in the Mycochytricliales. While the Holochytriaceae may have priority over siparrow's family name, the suffix chytriacea (a)ries the connotation that these fungi are chytrids. which is incorrect in light of presentday knowledge. The name is the refore no longer appropriate and descriptive. The present author is accordingly adopting the sirolpidiaceace in preference to the Holochytriaceace, but only as a temporary convenience because it in not at all certain that Sirolpidiam and Pontisma constitute a distinct family. so far only vecretative thalli. zoongorangix, and zoospores laive been addequately dencribed, and very little. if anvthing. conclusice is known about the resting spores and their method of development.

since the thalli and zoospores of l'ontisma are not strikingly different from thone of Sirolpirlium, the two genera are herewitl, merged. and the former eronus is reduced to a syonym of the latter. Petersenta in a limited sense is also included in this family herause its thalli are frecpuent? similar to those of Sirolpidinm. Obvionsly. this arrangement also may be completely invalidated ly future discoveries. As the fannily is herewith prescinted it includes two grenera of incompletely known holocarpic specien characterized by olpodionol or elongale and sometimes filanentous thalli which may or may not undergo segmentation. In some speries the segments separate and lecenne transformed directly into zoosporangi:.

\section{SIROLPIDIUM}

Petersen. 1905. Overs. Kigl. Dansk. Vidk. Selsk. Forh. $5: 478$.

Pontisma, l'etersen, l.c.. p. 48:2.

(PLATES 16, 17)

Thallus predominantly intramatrical but lecoming partially extramatrical under certain conditions: olpidioid or clongate and filamentous; transformed directly into a single sporangium or undergoing se $]^{\text {- }}$ tation and framentation to form a row of separate sporangia; fragmentation reduced or lacking in some species. Zoosporangia usually numerous in the host rell, variable in size and shape with one simple or hranched exit tule which varies markedly in length and maye extend considerally beyond the surface of the host wall, or oecasionally opening within the host [e]l. Zoonspores isocont with the Hagella attached at or near the anterior end (?) and extending in opposite directions: swarming within the sporangia, cmerging lully developed and swimming directly away: occasionally liberated within the host cell. Resting spore doubtful or nuknown.

'This eremus was ereated he Petersen for de Bruyne's Olpidium Bryopsidis after he laad found that the zoosjores are biflagellate instend of uniHagedlate. In the writer's opinion, Pontisma doess not differ fundamentally from Sirolpidiume, and an the hasis of present-day knowldedge it may well he merged with the latter gemus. Sparrow ('35) maintained that it differs from Sirolpidium by it more irregularly tuhular thallus and the fact that the segments do not sejarate and form isolated and frece sporangia. Sivertheless. lostl he and l'etersen refort that in cxeceptional case's the thalli alperar to fragment and give rise to free or loosely connected 
sporangia as in Sirolpidium. This striking similarity becomes evident when figures 13 and 14 . Plate 16 , of $S$. Bryopsidis are compared with figures 4 and 5 , Plate 17, of S. (Pontisma) lagenidioides. The tendency to greater or less frugmentation may well be a specific instead of a generic difference. Sparrow further reported that the zoospores are slightly different in the two genera, but his descriptions and figures of the positions of flagella are somewhat indefinite and unclear. Here also the differences may be only specific.

Infection of the host and the early developmental stages are not well known in all species. and the following acconnt of these processes is based largely on S. Bryopsidis. As in Eurychasma and Eetrogella, the zoospore comes to rest on the host cell, encysts, and soon develops a germ tube which penetrates the host wall. Its content flows into the host cell, while the spore case and penetration tube are left behind and remain attached for some time after germination. According to de Bruyne, the young thallus (figs. 6-8, plate 16) very early develops a wall or nembrane which thickens with age and shows a weak cellulose reaction when tested. The thallus may develop into an oval, prriform, ellipsoidal sporangium or elongate into a tubular filament, become septate, and then fragment into a number of segments (figs. 11 , 12,13, plate 16). These fragments then develop into olpidioid sporangia of various sizes and shapes (figs. 1.4, 15. plate 16) and form one simple or hranched exit tuhe of variable length. The latter may curve alout in the host cell or penetrate the latter's wall and project for a long distance on the outside (fig. 1, plate 16). The same type of development apparently occnrs in $S$. lagenidioides with the exception that the segments of the irregularly elongate thalli rarely separate.

The protoplasm of the thalli and incipient zoosporangia is glistening and refringent in appearance with numerous suspended globules (figs. 6-9, plate 16 ; figs. 4, 5. plate 17 ). When young the zoosporangia contain numerous small vacuoles (figs. 14,15 , plate 16 ; fig. 6 , plate 17 ) which apparently How together at miturity and form a large central one as in Olpidiopsis, l'ythiella, and other similar genera. So far nothing is known about cytokinesis, but it is apparently accomplished by centrifugal cleavage furrows which progress from the horder of the central vacuole to the periphery and therehy delimit uninucleate spore rudiments. The zoospores complete their development in the sporangium (fig. 1 , plate 16 ) and hecome very active and motile before the tip of the exit tube deliquesces. According to Sparrow they swim directly away after energing, lout de Bruyne reported that in S. Bryopsidis they may pause for a few moments at the tip of the exit tube and hecome amochoid. He also figured them as anteriorly uniflagellate and occasionally undergoing division (figs. 4. 5, plate 16). Pctersen reported them to be nni- and biflagellate, but according to Sparrow they possess two flagella of equal lengtl insertcd at or near the anterior end (fig. 2 , plate 16). His figures of fixed and stained zoospores (fig. 3, plate 9), however. show the two flagella laterally attached. In $S$. lagenidioides, he reported that the two flagella appear to arise from the concave central region (fig. 2, plate 17), while in some zoospores they seem to be attached to the narrow anterior end (fig. 3, plate 17).

The presence of resting spores has not been demonstrated with certainty in Sirolpidium. In S. Bryopsidis, de Bruyne reported that the contents of oval and globular thalli may contract and become inrested with a thick hyaline smooth wall (fig. 18 , plate 16), and. according to Sparrow ('34) Petersen also observed occasional thick-walled spores which he believed relate to this species. So far none have been found in S. lagenidioides.

Unlike Eurychasma and Eurychasmidium, Sirolpidium does not cause enlargement of the infected cells. Furthermore, neither they nor adjacent healthy ones are stimulated to divide. The effects of the fungus are local and confined to infected cells. In the case of Bryopsis infected with S. Bryopsidis, heavily parasitized plants may be recognized by the presence of blackened areas along the fronds, which are apparently areas in which the cells have been killed. As the parasite increases in size the plastids turn greenish-brown in color and eventually become clumped together with the remainder of the degenerating protoplasm, according to de Bruyne's figures. Sirol pidium lagenidioides, on the other hand, appears to be a weak parasite or saprophyte on Ceramium and is capahle of growth and development under conditions unfavorahle to its host.

\section{PLATE 16}

\section{Sirolpidium Bryopsidis}

(Figs. 1. $+9,18$ after de Bruyne, 90; fig. 11 after Potersen, 05; figs $2,3,10,12-17$ atter Sparrow. 34.)

Fig. 1. Tip of Bryopsis plumosa branch with four zoosporangia eontaining zoospores; the exit tube of one sporangium is antirely intramatrical.

Fig. 2. Free hand drawing and interpretation of the zoospore showing tapering anterior end witl a refractive globule and the ventral groove from which flagelia apparently arise.

Fig. 3. \%oospore killed in osmic acid fumes.

Figs. 4, 5. Division of zonsprores.

Figs. 6-8. Young thalli with numerous refractive globules.

Fig. 9. Elongate and branched thalli.

Fig. 10. Young stage of fragmenting thallus.

Fig. 11. Early stage of thallus division.

Fig. 12. Elongate thallus fragnenting; traces of old thallus wall connecting the fragments.

Fig. 13. Elongate tragmented thallus.

Fig. 14. Fragments bucoming transformed into zoospesangia.

Fig. 15. Incipicnt, racuolate, lobed zoosporangium with long exit tube.

Figr. 16. Emergence of zoospores trom olpidioid sporangia.

Fig. 17. 'Tip of Bryopsix filament with numerous olpidioid sporangia. 
PIAT'L 16

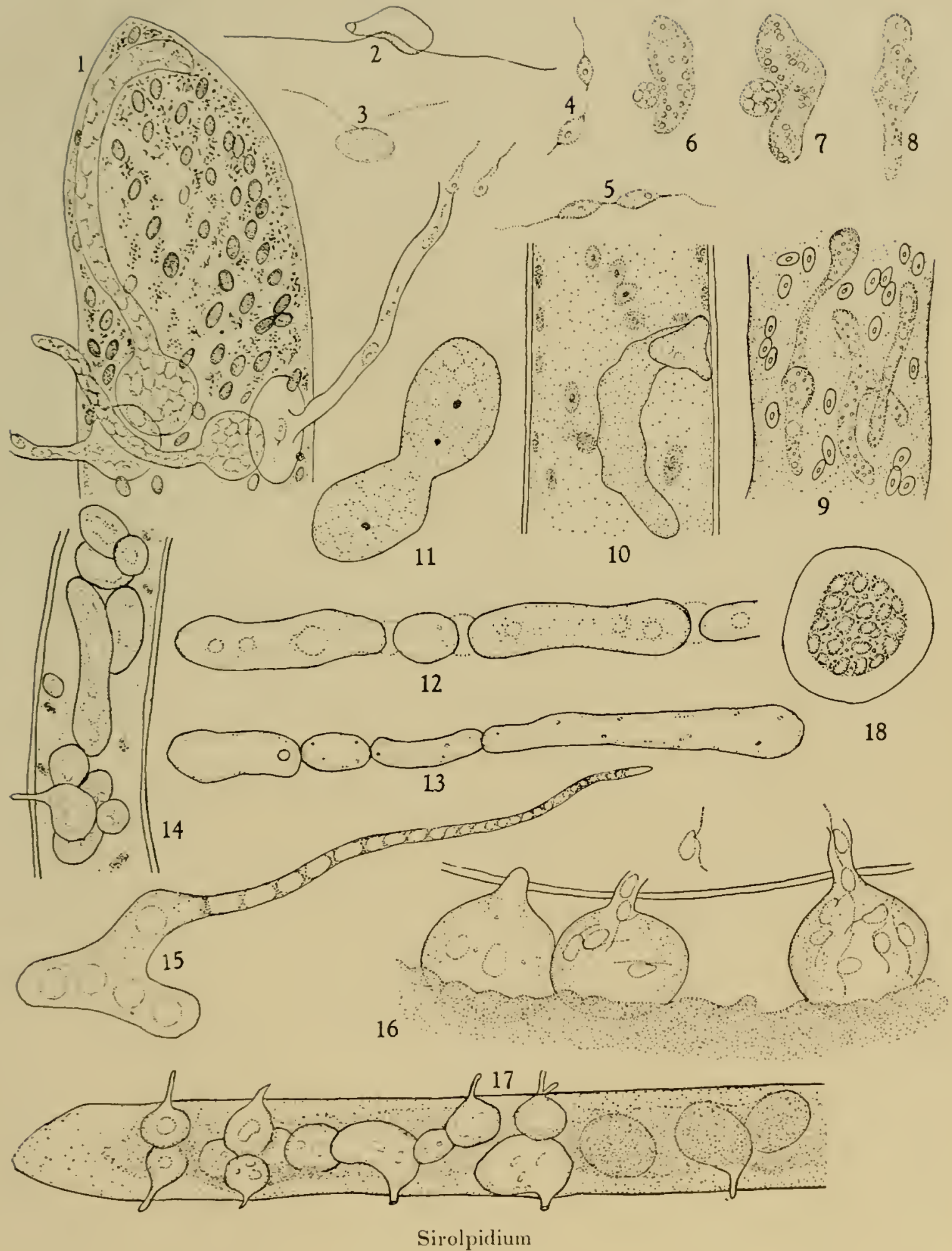


S. BRYOPSIDIS (de Bruyne) Petersen, l.c., p. 479. Fig. XI, $1-8$.

Olipidium Bryopsidlis de Bruyne, 1890. Arch. Biol. 10: 85. Pl. 5, figs. $1-15$.

Thallus usually intramatrieal, heeoming partially extramatrical under certain conditions; small, unicellular and olpidioid, or elongate, tubular and filamentous; frequently hecoming septate and undergoing fragmentation into unicellular segments which develop into sporangia. Zoosporangia usually mumerous in a cell, hyaline and smooth. spherieal, oral, ellipsoid, 12-17 $\mu \times 13-38 \mu$, elongate, eylindrieal, tubular, 3-5 $\mu \times 6-165 \mu$. Zoospores narrowly priform and slightly arched, $2 \times \pm \mu$, witl a refringgent granule at the anterior end; flagella inserted near the anterior end (?). Resting spore (?) spherical, oval and elongate, hyaline and smooth. germination unknown.

Parasitie in Bryopsis plumosa in Italy (de Bruyne, l.e.), Demmark (Petersen, l.c.; Sparrow, 3.4) and IIassachusetts. U. S. A. (Sparrow. '36); and saproplytic (?) in Cladophora sp., in Massaelusetts, U. S. A. (Sparrow, l.c.).

In material studied at Woods Hole, Mass.. Sparrow found that the growth of the thallus may be markedly influenced hy euvironmental conditions. When the host is removed from its normal habitat and exposed only to dripping sea water the fungus grows out of the host and becomes distinctly filamentous and hypha-like. Sparrow found that additional extramatrical growth eould he indueed by transferring the infeeted material to solutions of low sugar eoneentrations. It is obvious from these preliminary culture studies that $S$. Bryopsidis is highly variable in growtli and development.

\section{S. LAGENIDIOIDES cuml), nov.}

Pontismal laypnidioiles Petersen, l.c., figs. X, 1-3.

Thallus intramatrical, oecasionally unicellular, lobed, curved and olpidioid; usually elongate, lobed. irregular and septate, frequently constricted at septa; rarely fragmenting into isolated segments. Zoosporangia hyaline and smooth, usually eonneeted, oceasionally free; oral, elliptical, i3-15 $\mu$ $\times 11-16 \mu$, elongate, cylindrieal, $130-200 \mu$ in length, or irregular and slightly lobed. Zoospores pyriform and arched, $2.5-3 \mu \times 4.5-7 \mu$, with a refraetive granule at one or both ends; flagella laterally inserted (?) on the eoncare side and oppositely directed; oceasionally liherated within the host ecll; motion erratic and tumbling in swimming. Resting sjores unknown.

Weakly parasitic or saproplytie in Coramium rubrum, C'eramium sp., C. fructiculosum, C. lemuissimum, and C'. diaphanum in Denmark ('Petersen. l.c.; Sparrow, '3.4) and Massachusetts, U. S. A. (Sparrow. '36).

Sparrow reported that the zoospores of this species are strikingly similar to those of Butler's (1.c.) Rozellopsis inflata, and helieved that on thest grounds Butler's speeies shows affinities witl $S$. lagenidioides and speeies of Olpidiopsis. It is to be noted again, however, that the flagella of S. lagenidioides (fig. 3 , plate 17 ) also appear to be attached to the narrow anterior end of the zoospores.

\section{PETERSENIA}

Sparrow, 1934. Dansk. Bot. Ark. 8: 13.

(PLATE 18)

Thallus entirely intramatrieal, unicellular, elongate, narrowly eylindrieal, irregularly lobed and contorted, rarely ellipsoid, and olpidioid ; oeeupying one or more host eells. Zoosporangia solitary or numerous, variously shaped with 1 to 4 exit tubes of rariable length. Zoospores laterally (?) biflagellate, isocont; flagella extending in opposite directions; developing completely and swaming in the sporangium before emerging. swimming directly away without any panse at the mouth of the exit tube. Resting spores doubt ful or unknown.

This genus was estahlished to include species of Pleotrachelus whiel were found to have liflagellate zoospores. It is not improbable that other marine speeies of the latter genus may also be transferred to Petersenia when their life eyeles and method of development are completely known. Petersenia andréei is apparently a species of Olpidiopsis and is aceordingly exeluded from this genns whieh leaves only one valid speeies, $P$. Iobata. The thallus of

PLATE 17

Sirolpidium layeniulioides

(Fig. 1 after Petersen, 05; figs. $2-9$ after Sparrow, 34.)

Fig. 1. Elongate irregular septate, constricted thallus with four exit tubes.

Fig. Q. Arched zoospores with a refractive granule at each end and two equal, laterally ( $\left(\begin{array}{c}0 \\ 0\end{array}\right)$ attached flagella.

Fig. 3. Free hand drawing and interpretation of zonspores showing flagella attached near anterior encl.

Fig. 4. Jrregular septate thallus.

Fig. 5. Group of thalli showing "rudimentary framentation."

Fig. (i. Vacuolate sporangium with a loranched exit tuhe.

Fig. 7. Curved elongate, continuous and solitary sporangium witl quiescent zoospores.

Fig. 8. Emergence of zoospores.

Fig. 9. Empty loosely attached sporangia.

\section{Blustulidiopsis chattoni}

(All drawings aftur Sigot, '31)

Fig. 10. Young vacuolate lobed thallus in egg of $C y-$ clops.

Fig. It. Section of cyclops egr showing lohes of sporangium in section; nuclei lying in a thin peripheral layer of cytoplasm.

Fig. 12. 1.atcrally biflagellate isocont zoospore with nucleus noar the center and a large refringent body at the anterior end. 
PIANTE $1 \%$

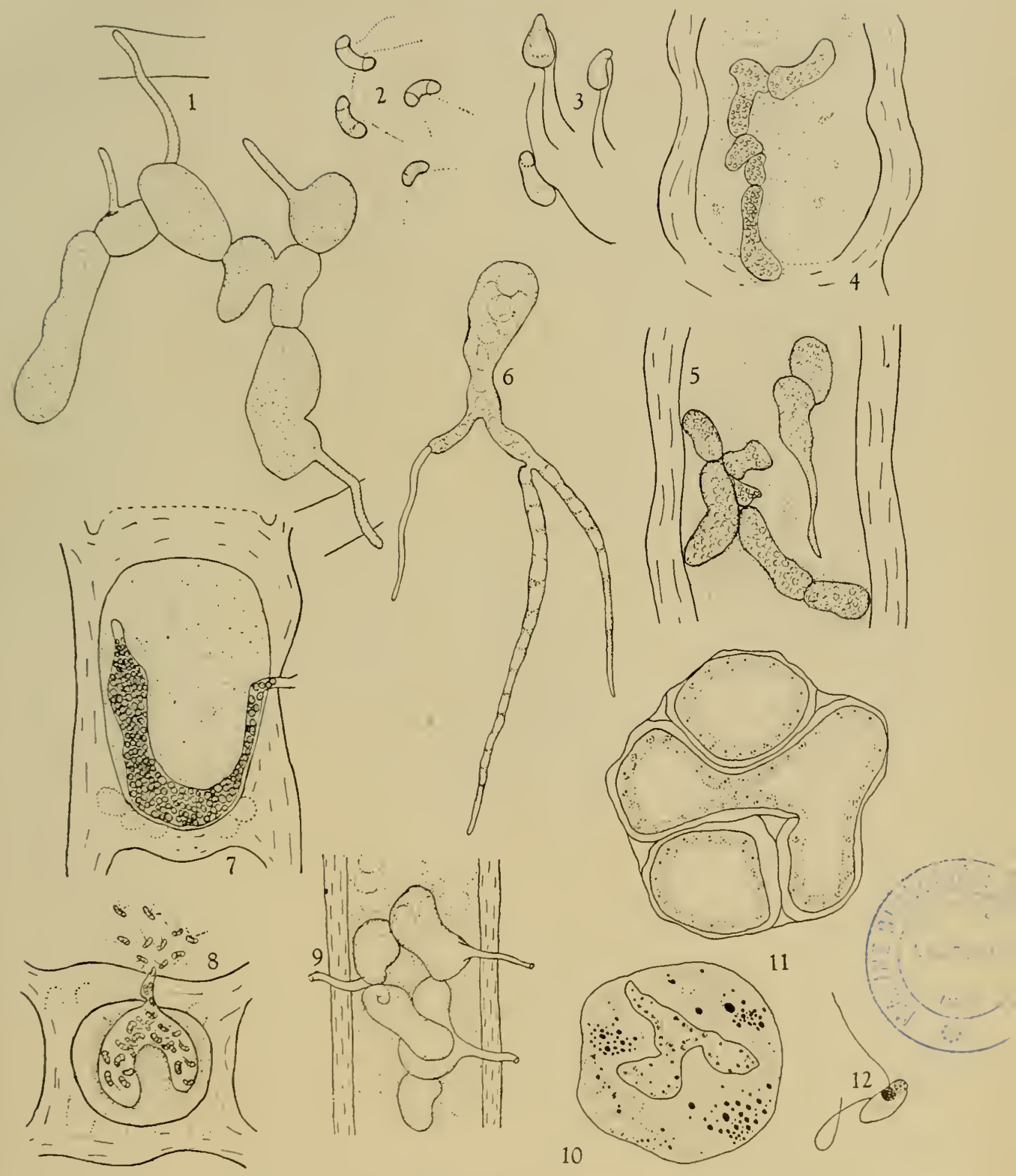

Sirolpidium, Blastulidiopsis 
this fungus may be strikingly similar in appearance to those of species of Sirolpidium, with the exception that it does not become septate and fragment into segments. Shonld the latter characters prove insignificant in generie diagnoses and phylogeny, Petersenia, in the present sense, may perhaps he merged with Sirol pidium. On the other hand, the olpidioid thalli bear a strong rescmliance to those of Olpidiopsis, particularly to O. irregularis, according to Sparrow (' 34 ).

Zoospore germination and infection of the host have not been observed in this genus, but these processes are probahly similar to those of Sirolpidium, Ectrogella, ete. Sparrow ('34) reported that in the early stages the thallus is "somewhat plasmodial in nature" but he did not illustrate any of the initial developmental phases. At maturity, however, a welldefined wall is present which stains a dark, ruby color when tested with chloro-iodide of zinc. As noted previously the thallus raries markedly in size and shape (figs. 3-8). Within the tetraspores of the host it usually assumes the shape of the confining cell (fig. \&), but even under such conditions lobed specimens may occur, as Feldman ('10) has shown. In the regetative state the protoplasm is refractive and vacuolate (figs. 1,7 ), and as the thallus is transformed into a sporangium. the small racuoles presumably flow together and form one or more larger central ones. The late stages of cleavage and sporogenesis closely resemble those of $P$ 'y thium, according to Sparrow. The incipient spore initials undergo an individual rocking morement which becomes more pronounced as they separate and acquire their mature form. At the same time traces of flagellary motion become visible at the periphery of the spore inass. and this increases in intensity until the zoospores are mature and swarming within the sporangium. As the tip of the exit tube deliquesces they emerge (fig. 3) and swim directly away. Aecording to Sparrow, the zoospores (figs. 1, 2) are elongate, pyriform, shallow-grooved. and contain a refractive body at the anterior end. The flagella are reported to be inserted laterally, but some of Sparrow's figures suggest that they arise near the anterior end.

P. LOBATA (Petersen) Sparrow, l.e., p. 13, pl. ?, figs. I-N ; 1936. Biol. Bull. 70: 24. Pl. Q, figs. 1, 2.

Pleotrachelus lobatus Petersen, l.c., P. 1(i0, figs. V. 1-7.

Zoosporangia solitary or numerous, often occupying more than one host cell, or filling it complctely and conforming to the latter's size and shape; usnally markedly and irregularly lobed, elongate and tubular, or oval, ellipsoid and olpidioid with 1 to 3 simple or branched exit tules of variable length. Zoospores elongate, pyriform, slightly arched and shallow-grooved, $3 \times 4.5 \mu$. Resting spores unknown.

Parasitic in the vegetative ceils and tetraspores of Spermothamnion turneri, s. repens, Callithamnion corymbosum and C. hooleeri, in Denmark (Petersen, l.c.; Sparrow, l.c.), C. roseum in Massachusetts,
U. S. A. (Sparrow, '36) and in the disporangia of Seirospora interrupta near Villefranche-sur-mer in the Mediterranean (J. and G. Feldman, ' 10$){ }^{1}$

This species may oceur in whitened and dead cells of its hosts which suggests that it is only weakly parasitic. According to Sparrow, it is not assisted by other organisms in the early stages of invasion, but in old infections, bacteria and protozoa are always present and aid in the destruction of the content of the host cell.

Whether or not Pleotrachelus pollagaster Petersen (figs. 9-11) belongs in P'ptersenia is questionable. Sparrow (' 34 ) included it provisionally in this genus, because he found its zoospores to be similar in shape and size to those of I'. lobata. He did not, lowever, determine the number and position of the flagella, and until these points have been conclusirely settled the exact generic position of $P$. pollagaster will remain doulbtful.

Sparrow ('36) found two other fungi whieh he assigned tentatively to Petersenia as midentified species. One oceurred in the eggs of a microscopic animal, possibly a rotifer, adherent to filaments of Ceramium diaphanum. The parasite filled the whole interior of the egg (fig. 12) and was transformed at maturity into a sporangium, $20 \times 50 \mu$, with 1 to 3 short broad, $8 \mu$ in diameter. exit tubes. The formation and emergence of the zoospores were not observed, although a number of the spores which had failed to emerge were found within sporangia. These bodies were reniform, "of the laterally biciliate type," $2 X+\mu$, and resembled the zoospores of

1 Bull. Soc. Hist. Nat. Afrique Nord 31 : $7 ?$.

PLATE 18

(Figs. 1-6, 11-14 after Sparrow, 34, '36; figs. 7-10 after Petersen, 05. Figs. 13, 14 ilrawn from plotograplis.)

\section{Peterseruia lobata}

Fig. 1. Group of isoeont zoospores; point of attachment of flagella uncertain.

Fig. 2. Freehand, enlarged drawing and interpretation of zouspore.

Fig. 3. Emergence of zoospore from olpidioid zocsporangium.

Fig. t. Infected tetraspores of spermothammium.

Fig. 5. Olpidioid and nodular thalli.

lig. 6. Irregular thallus with four short branehes.

Fig. 7 . Elongate, lobed aud constricted multivacuolate thalfus occupying two host cells.

Fig. 8. Empty zoosporangium.

$$
\text { Pleotrachelus (Petersonia) polloguster }
$$

Fig. 9. Lobed thallus with three long exit tubes.

Fig. 10, Olpidioid sporangiun.

lig. 11. Irregular resting spore.

$$
\text { Peterseniu s]. }
$$

Fig. 1:. Sporangium in rotiter (?) rgg with two biflagellate isocont zoospores.

Fig. 13. Young thallus of Petersenire sp. saprophytic in Cerentum stiuphenum.

Fig. 14. Empty zoosporangium with three exit tubes. 
PIATE' 18

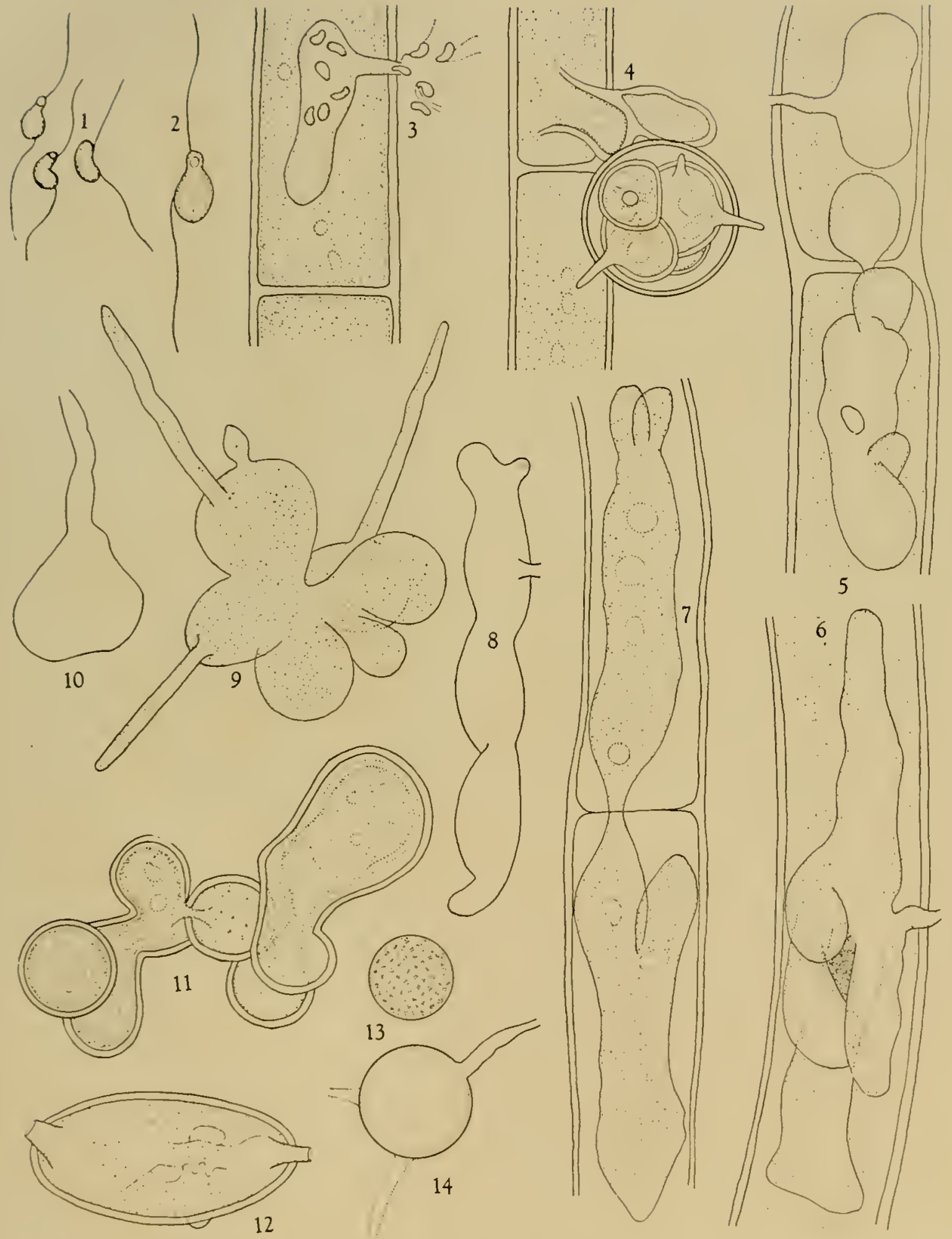

Petersenia 
Pythium. The other unidentified speeies oeeurred as a saprophyte in Ceramium diaphanum which had been kept in a laboratory aquarium for several weeks. One to several spherical (figs. 13-14) and irregular thalli of variable size, $20-96 \mu$ in diameter, were found in a single internode. Each thallus de- veloped into a sporangium at maturity with up to ten or more radiating, narrow tapering exit tubes, $7 \mu$ in diameter, which penetrated the host cell wall. Zoospores and resting spores were not observed, and it is accordingly uncertain whether or not this speeies belongs in Petersenia.

\title{
Chapter VI
}

\section{Lagenidiaceae}

\author{
Schroeter, 189\%. Engler und Prantl, Die Nat. Pflanz'f. I, 1: 88.
}

Thus family ineludes a number of saprophytes and parasites of algae, higher plants, nematodes, insects, and other animals whieh are eharaeterized primarily by reniform, laterally biflagellate zoospores, and sexually formed resting spores. The family was formerly ineluded in the Aneylistales, but in light of Miss Berdan's ('37, '38) diseovery that Ancylistes is a genus of the Entomoplithorales, the name Aneylistales is no longer tenahle. Accordingly, in 1939 the author raised the family Lagenidiaceae to ordinal rank, and sinee that time Sprarrow ('42) has included the Olpidiopsidaceae, and Sirolpidiaceae as well as the Lagenidiaceae in this order. Whether or not these families constitute a distinet order of equal rank with the Saprolegniales, I.eptomitales, Peronosporales, ete., is very questionable. According to Sparrow's interpretation the Lagenidiales inelude speeies with iso- and heterogamous types of reproduction as well as iso- and heterocont zoospores, and as such it obvionsly eannot be regarded as more than a temporary and convenient expedient of classification. In view of our lack of knowledge relative to many of the speeies, genera, and families included in this order, it is perhaps wiser for the time being to avoid placing the Olpidiopsidaceae, Sirolpidiaceale, and Lagenidiaceae in a distinct order.

The thallus of the Lagenidiaceae varies from a simple ovoid, unieellular, Olpidium-like eell to an extended filamentous, branehed, septate mycelium which may he eonfined to a single host eell or oceupy several eells. These parasites and saprophytes gain entrance into the host by an infeetion tube from germinating zoospores. The thallus develops as an extension and enlargement of the tip of the gcrm tube and soon becomes long and filamentous or enlarges into a globular, oval, loled, and irregular structure. It may remain unicellular and continuous in some speeies or divide transversly into several segments. Witl further growtl these segments may heeome oval, ellipsoid, and spherical, making the thallus deeply lobed at the septa, or they may remain cylindrical with little or no eonstrictions in the region of the eross walls. At maturity these segments are holocarpieally transformed cither into zoosporangia or slightly differentiated gametangia. In all speeies whieh have been tested the walls of the thallus give a marked positive eellulose reaction. The protoplasm, particularly in Lagenidium and $\boldsymbol{M}_{y z o-}$ cytium, usually inchudes a large number of refractive globules of various sizes, whieb give it a charaeteristie refringent and gleaming appearanee, but at maturity and as sporogenesis begins it becomes more greyish granular.

In the majority of species the eontent of the sporangium emerges as a globular mass from the exit tube and undergoes eleavage into zoospores on the outside in mueh the same manner as in Pytlium. The prescnec of a vesienlar membrane around the protoplasmie mass and the zoospores whieh are subsequently formed lias been reported in a number of spceies, but appears to be lacking in others. There is considerable disagreement in the literature abont the presenee of this structure, and further intensive study of its oecurrence in the Lagenidiaceae is needed. In a few speeies the zoospores are eompletely dereloped in the sporangium, emerge, and swim directly away, or they are diseharged prematurely, eome to rest in a mass and complete their development on the outside. In other speeies they eneyst in a loose mass at the mouth of the exit tube as in Achlya and exhibit marked diplanetism. It is aeeordingly obvious that the process of zoosporogenesis and the initial belavior of the zoospores vary from the Olpidiopsis to the P'ythium and Achlya trpes. The zoospores throughout the family are predominantly reniform and somewhat pyriform in shape, and in some species a distinet ventral groove is present in which the flagella are inserted. Heterocont zoospores have been rejorted in two species.

Sexual reproduction is predominantly heterogamous, but in Lagena and Resticularia it is reported to be isogamous. Isogamy is present in Lagenidium sacculoides also, aecording to Serbinow ('07). The segments of elongate thalli, as well as entire uniecllular thalli, which fumetion as male and femalc gametangia are ouly slightly or not at all differentiated as sexual organs. They may oeeur among the sporangia in the same thallus or in separate thalli, but the presence of heterothallism has not been definitcly proven. No monozoospore cultures and infec- 
tions have ret loen made to determine whether the yoospores earry the potentialities of one or both sexes. In soume of the unicellular species separate thalli may function as male and fomale gametangia, lut it has not hecon proven that ther represent distinct male and fomale strains. In light of our meager present-day knowledge it would he premature to disenss homo- anel heterothallism in the lagenidia(e'ate.

In some species the unicellular thallus may divide at maturity into two cells which then function as male and female rametangia. respectively. In most species. however, the female ganetangium is usually larger. more vesicular, and frequently barrelshaped. While the so-called antheridium is usually clongate and tuhular. In Lagena, as noted hefore. the unicellular thalli which fuse are cqual in size and indistinguishalle. For this reason, the terms oogonia and antlueridia may be used only tentatively and witl reservation for the sexual organs in the lagenidiaceac. l)ifferentiation of an egg cell and periplasm in the female ganctangium has not been eonvineingly demonstratcd, but the ooplasm may contract and aggregate tow ard the conjugation tube or pore during plasmogamy. Slortly hefore fusion a conneeting pore is formed between the two gametangia, or the antheridium forms a tube or canal which projects into the oogonium. In Lagena, lowever, the tube fuses with tlie surface of the oogonium without entering it. 'The eontent of the antheridium then slowly flows into the oogonium and fuses with the ooplasw, after which the zygote becomes invested witl a thick wall. The resting spore thus formed lies free in the ongoninm, resembles the oospore of the higher Oonycetes, and is gencrally referred to in the literature as an oospore. In some speeies the antlueridium is lacking. with the result that the resting spores are formed partlenogenetically.

'The eytology of sexual reproduetion from fixed and stained naterial las been studied in only one species, and rery little is knuwn abont the gametie nuclei and their hebavior during plasmogany and karrogamy in the fanily as a whole. Until more is known about these developmental phases the relationships of the Iagenidiaceae with the Saprolegwiales and Peronosporales will remain ohseure.

$A$ it is herewith presented the lagenidiaceae inclucles Lagenidium, Myzocytium, and Lagena. The first two genera are very similar and appear to be clucly rclated, and in light of present-day knowledge it is questionable whether they should be separated. As Cook ('35) has already noted, the differcnees are perhaps only specific instead of generic. Lagenidiopsis is merged with Lagenidium, while Achlyogeton and Mitochytridium are cxcluded hecause of their uniflagellate zoospores. Kesticnlaria is listed as doubtful genus, hut it may possibly prove to be identical to and syuonymous with Lagenidium. Its reported isogamous and zygomyectons type of scxual reproduction is very sinilar to that of $I$. sacculoides. On the other luand. future studies and discoveries may necensitate the inclusion of Lagena,
Resticularia and $L$. sacculoides in a scparate family because of their characteristic method of sexual reproduction. Protaseus is axeluded from the lagenidiaceae because of its lack of zoospores. A full description and illustration of this gems is nevertlueless presented liere to emplasize again to myeologists the priority of Damgeard's I'rolascus over the same generie mane proposed hy Wolk ("13) for another fungus.

Gaumann and Gaumaun and Dodge inclueled Eetrogella in the Iagendiaceac, but sulsequent workers have not followed this vicwpoint. The presence, however, of isocunt primary zoospores with flagella inserted just helow the anterior end and laterally biflagellate heterocont secondary swarmspores indicates a closer relationship, as Selierffel has pointed out, with the Saprolegniaceac. Tokunaga included Aphanomycopsis in this family on the gromnds that it lacks a typieally developed nycelium and is holocarpic. The shape, structure, size and general appearance of the thallus and zoospores are strikingly like those of the Lagenidiaceae, and in the encystment of the swarmspores in a eluster at the mouth of the exit tube this genus is similar to $L$. Oedogonii. Furthemore, the locally panmely cell in which the asexual or possibly parthenogenetie resting spore is formed is quite like the oogonimm in species of Lagenidium. There is thus good structural evidence to support Tokunaga's viewpoint. Whether certain stages of Borzi's Rhizomyxa belong here is also problematical. Its reported mode of sexual reproduction is nonetleless strikingly similar to that of Lagenidium and Myzocytium, with the exeeption that an egg eell and periplasm are formed hefore fertilization oecurs. In the latter character it is somewhat similar to Pythiella.

\section{LAGENIDIUM}

Schenk, 1859. Verth. Phys. Med. Ges. Wursburg $9: 2 \%$.

Lagenidiopsis de Wildeman, 1896. Ann. Soc. Belg. Micro. 20: 109.

(ILATES 19, 20)

Thalli intramatrical, solitary or mumerous, eonfined to one eell or extending through several loost cells ; frequently elongate, straight, crooked, curved, irregular, eoiled, tulular, hypha- and myceliumlike, with mumerous blunt protuberances: lobed. branclied or unbranclicd. sliglitly constricted or unconstricted at the cross walls; multicellular or uniccllular. the latter continuous. glohular, oval, cllipsoidal, sac-like and irregular: of ten attached to the host cell wall hy the infection tuhe and zooppore ease; holocarpic, transforncel into sporangia or gametangia at maturity. Sporangia of the same shape and size as the individual segments and uni cellular thalli, with one to scceral exit tubes of vary- 
ing length, diameter, contour, and shape; content of sporangium usually emerging to form a globular mass at the month of the exit tube. Zoospores beanshaped, reniform and somewhat pyriform, laterally biflagellate, with several small refractive globules, mono- or diplanetic; primary swarmers isocont, secondary swarmers heterocont; formed (1) extramatrically by progressive cleavage of the extruded globnlar mass of protoplasm which may be naked or surrounded by a resicular nembrane as in Pythium; (2) delimited in the sporangium, emerging singly and completing development at the mouth of the exit tulse; or (3) completely developed in the sporangium, emerging in succession and swimming directly away. Antheridia borne on the same or different thalli; oogonia terminal or intercalary, varionsly shaped: differentiation of egg cell or oosphere prior to fusion absent or very doubtful ; epiplasm lacking; content usually contracting toward the conjugation canal during plasmogamy. Antheridia when present usually more slender, elongate and cylindrical, frequently forming a conspicuous perforation and conjugation tube which extends into the oogonium; fused protoplasts contracting and becoming inrested with a definite wall. Oospores sexual or parthenogenetic, lying free in the oogonium, usually spherical, oval or ellipsoidal, smooth or warty, hyaline or colored, thick-walled with one or more large refractive globnles; germinating by giving rise directly to biflagellate zoospores.

This is the largest genus of the family and includes approximately fiftcen species, some of which are doubtful, incompletely known, and possibly synonymous. The majority are parasites of algae; two occur in tissues of higher plants, and two live in the body of insects. A number of species occur on the same host and are structurally similar. It is thus probahle that when extensive cross inoculations have been made and the range of rariation of the individual species is known some of them will prove to be identical. As to geographic distribution, they have been reported from Asia, Europe, and North America.

As is shown in figure 1 , the zoospores come to rest on the host cell and penetrate it by a germ tube of varying length and diameter, tip of which enlarges as the content of the spore passes into it. This tip soon elongates into a comparatively thick hyphalike tubular strand as in L. rabenhorstii (figs. 2-4) or enlarges into a globular, oval, vesicular, sac-like and somewhat irregular structure as in L. brachystomum, L. enecans, L. Oedogonii, etc. (figs. 30, 39, $45,49)$. This enlargement of the tip eventually develops into the mature thallus and in several species is attached to the host wall by the persistent zoospore case and infection tube. With further growth and increase in diameter, the thallus of the more extensive and elongate species derelops a few side branches and numerous protuberances which often make it very irregular and crooked. As its ends approach the limits and cross walls of the host, they may cither penetrate into adjacent cells or donble back in the same cell (fig. 34). Very shortly transverse septa are formed at more or less regular intervals in such thalli, and they thus are divided into a linear series of elongate, eylindrical or irregular segments. In some sprecies like $L$. Closterii, $L$. marchalianum, L. giganteum, etc. (figs. $34,37,54$ ) the thallus is quite narrow, mycelioid and Pythiumlike, while in L. pygmaeum, L. Cyclotellae, $L$. Oedogonii, and $L$. oophilum it may le reduced to a single globular cell as in Olpidium (figs. 25, 39, 49, $60)$.

The protoplasm of the thallus includes numerous fairly large refractive bodies which give it the whitish, refringent gleam characteristic of the family Iagenidiaceae. In addition several small vacuoles are usually present. The segments of the thallus or whole thalli are transformed directly into sporangia, oogonia and antheridia. In the case of sporangia the small vacuoles may run together to form a large central one by the time the exit tubes have developed. As sporogenesis approaches, the large refractive bodies apparently break up into smaller fragments and becone highly dispersed, so that the protoplasm loses much of its refractive appearance and becomes more greyish granular. The exit tubes vary considerably in length, diameter, shape, contour, and the extent to which they project beyond the host wall. They may be inflated at the base or just before they pass through the host wall, constricted or unconstricted, straight, curved, irregular or tortuous, and end almost flush with the surface of the host, or extend considerably beyond it.

In all species except $L$. pygmaeum, L. Cyclotellae, and $L$. oophilum the protoplasm of the sporangium is reported to emerge at maturity and form a spheri-

\section{PLATE 19}

\section{Lagenidium rabenhorstii}

(Figs. 1-14, 16 after Zopf, '84; figs. 15, 17 after Cook, 35; figs. 18-22 after Wildeman, '96.)

Fig. 1. Early infection stages of Spirogyra cells. Figs. 2-4. Successive developmental stages of thallus.

Fig. 5. Sporangium with emerged contents surrounded by a membrane.

Figs. 6-8. Successive stages of cleavage and maturation of the zoosjores.

Fig. 9. Small, reduced thallus witl zoosjores swarming in a vesicle.

Fig. 10. Mature zoosjore.

Figs. 11-14. Stages in fusion of the contents of antheridium and oogonium.

Fig. 15. Prefusion stage showing differentiation of an egg cell in the oogonium.

Fig. 16. Mature oospore in oogonium of an elongate thallus.

Fig. 17. Single, Jarge zoospore produced by germinated oospore.

Lagenidium (Layenidiopsis) reductum

Figs. 18, 19. Young and clongate unicellular thalli. Fig. 20 . Antleridium, oogonium, and warty oospore. 
PIATE 19

(0)
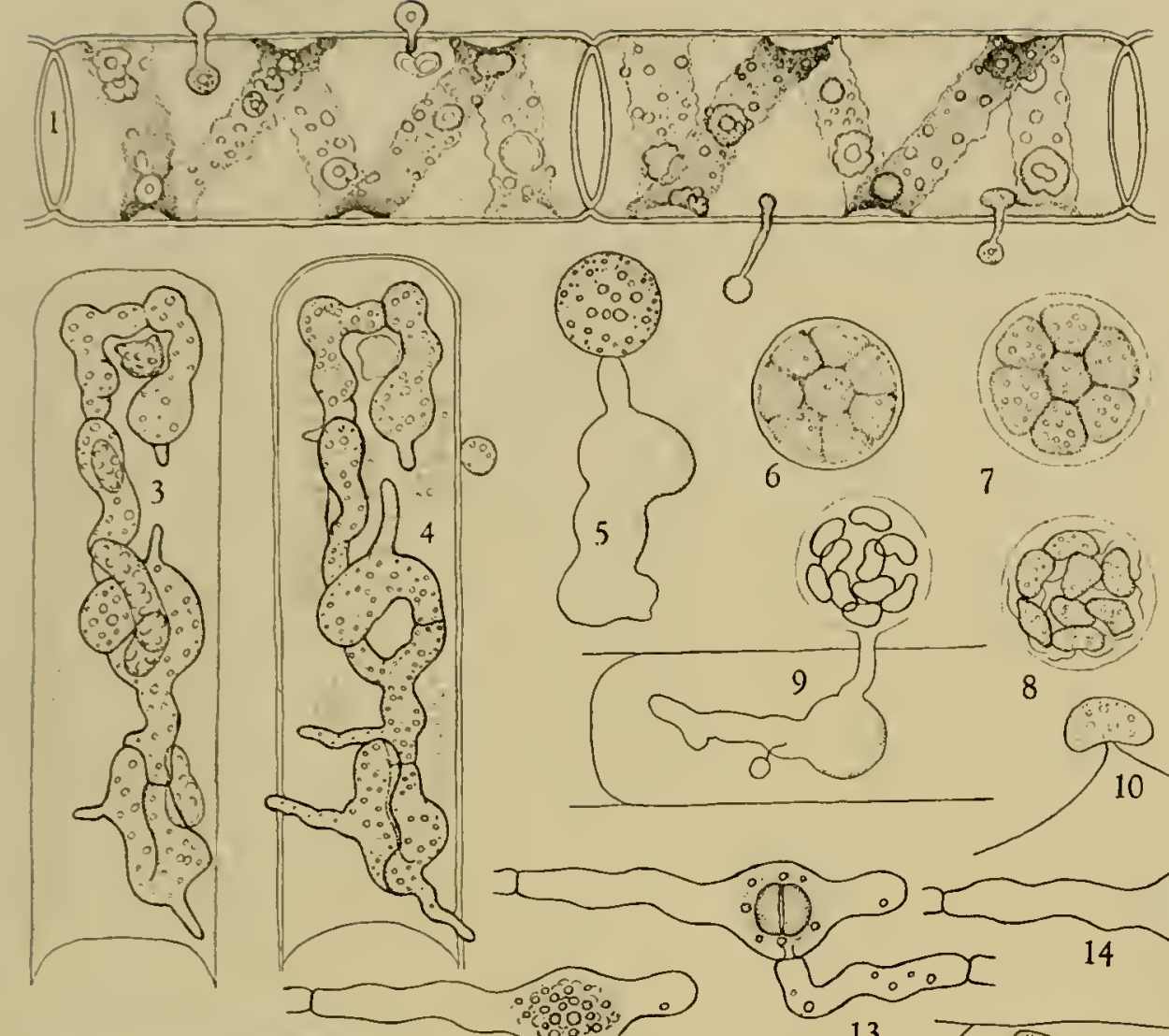

000000
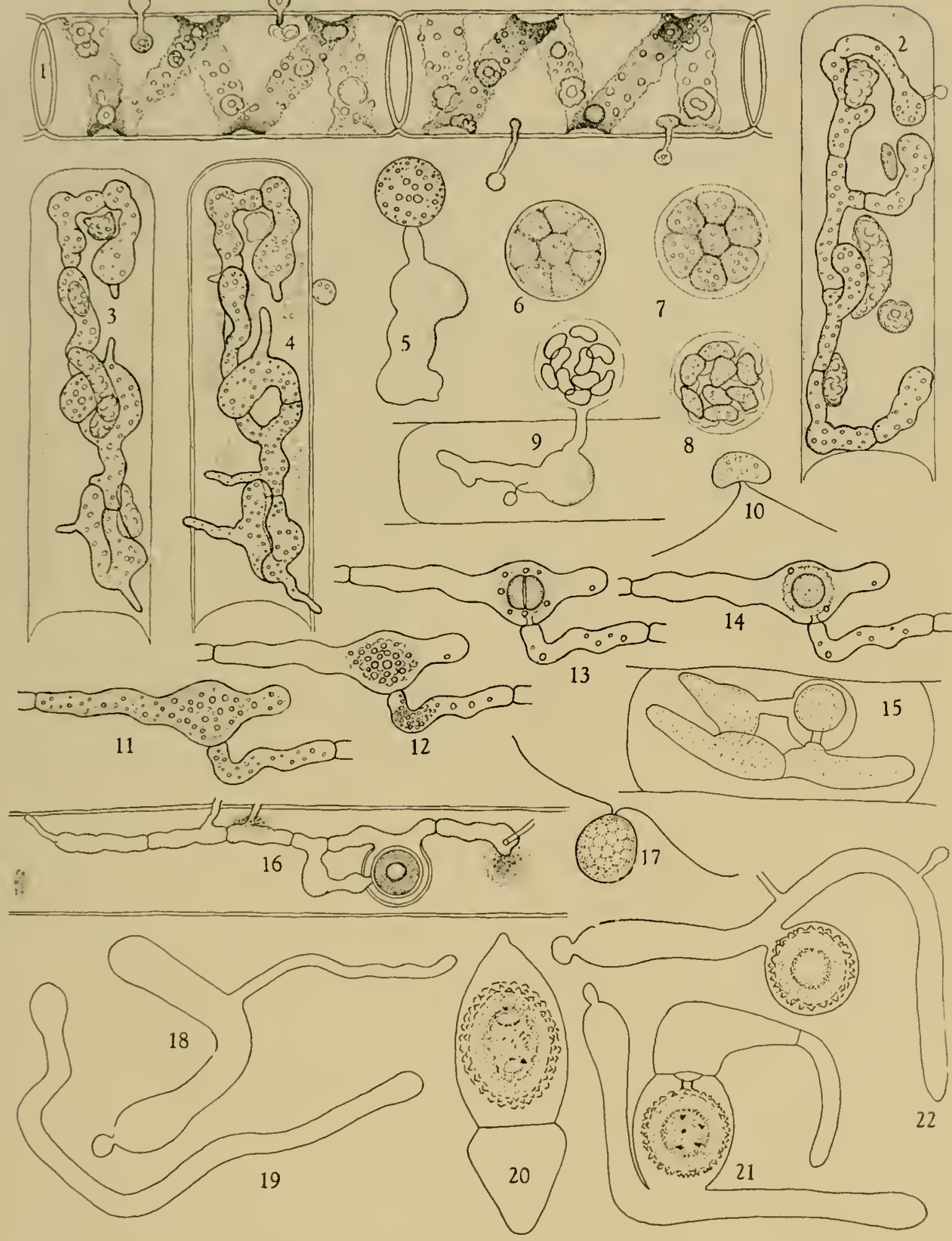

Lagenidium, Lagenidiopsis 
cal, oval or slightly irregular, glohular mass at the mouth of the exit tube. As will become more evident in the diagnoses of individual species, inrestigators are not in agreement as to whether this mass is naked or enclosed in a definite membrane as in Pythium. According to present data the latter is apparently present in some species and lacking in others, but a careful restudy of this structure is necessary before the problem is settled. The protoplasmic mass may be vacuolate and undergo marked rocking or oscillating movements shortly after emerging, and in some instances it may even move or be carried away from the exit tube. In L. giganteum the protoplasm may occasionally emerge in several separate masses, according to Couch (' 35 ). Cleavage hegins very soon, and in most species it appears to be progressive and centripetal. In the masses which possess a large central racuole, i.e., L. Oedogonii and L. giganleum, cleavage is largely centrifugal in direction. While cleavage is going on the slow oscillating or rocking movement continues, and as the process is completed and flagella develop at the outer periphery of the individual segments, and this motion is augmented by that of the rudimentary zoospores. Cleavage stages in L. giganteum have been intensively studied at different time intervals by Couch. As the protoplasm emcrges it includes one or more large central vacuoles and numerous small peripheral ones (fig. 55). The central vacuoles fuse (fig. 56), but the peripheral ones remain intact and are eventually included in the zoospores. Flagella in pairs are formed on the periphery of the mass opposite the small vacuoles, and shortly thereafter clearage furrows derelop centrifugally from the central racuole and divide the mass into biflagellate, univacuolate segments. The central vacuole collapses as the furrows reach the periphery, and as a result the zoospore mass contracts (fig. 57 ). The zoospores soon begin to oscillate individually and glide upon each other as they mature, and within a few minutes they are actively swarming in a localized and restricted region (fig. 58 ). It is this localized swarming in numerous other species which suggests or indicates the presence of a retaining membranc, although it often cannot be clcarly seen. Shortly thereafter the swarmspores separate very quickly as if they had been freed by the rupture or deliquescence of the membrane. In species where no membrane occurs, the zoospores pull apart more gradually as they mature, and soon swim away.

In $L$. pygmaeum and $L$. oophilum the incipient zoospore segments are delimited in the sporangium, emerge in succession, and complete their development near the mouth of the exit tule, while in $L$. Cyclotellae they are developed completely in the sporangium, emerge singly, and swim directly away, according to Scherffel ('25). Lagenidium Oedogonii is particularly interesting and significant relative to its zoospores. They may develop either extramatrically in a vesicle, as in Pythium, or within the sporangium. In the latter case they collect in a cluster at the mouth of the exit tube after emerging

\section{Plate 20}

Figs. 23, 24. Irregular contorted thalli of L. entophytum with smooth and warty oospores. Zopf, '84.

Fig. 25. Olpidium-like thallus of $L$. pygmaeum with partially formed zoospores emerging in a vesicle. Zopf, 87.

Figs. 26, 27. Encysted and motile zoospores of $L . p y g-$ mae um. Zopf, l.c.

Figs. 28, 29. Mature oos] ores of L. ${ }^{\prime \prime y g m a e u m . ~ Z o p f, ~ l . c . ~}$

Fig. 30. Empty thallus of $L$. enecans from a Cymatopleura solea cell. Scherffel, '25.

Figs. 31, 32. Heterocont secondary swarmers or zoospores of $L$. enccans. Scherffel, l.c.

Fig. 33. Oospores, L. enecrns. Scherffel, l.c.

Fig. 34. Portion of filamentous thallus of $L$. Closterii. Couch, '35.

Fig. 35. Inflation of exit tube before passing througl host wall. Couch, l.c.

Fig. 36. Zoospore of L. Closterii. Couch, J.c.

Fig. 37. Thallus of $L$. marchalianum in Oedogonium cell. Couch, l.c.

\section{Oedogonii}

Fig. 38. Germinated zoospore and cellulose plug formed around germ tube. Couch, l.c.

Fig. 39. Unicellular thallus transformed into a zoosporangium with contents beginning to emerge. Couch, l.c.

Fig. 40. Vacuolate content of sporangium after emerging. Couch, l.c.

Figs. 41,4 ? Side and ventral views of heterocont, secondary swarmers or zoospores. Scherffel, l.c.

Fig. 43. Encysted zoospores at mouth of exit tube. Scherffel, l.c.

Fig. 44. Oospore. L. brachystomum. Selierffel, l.c.

Fig. 45. Elongate, unbranched thallus from Gomphonema cell. Scherffel, l.c.

Fig. 46. Zoospores in a vesicle. Couch, l.c.

Fig. 47. Zoospore. Couch, l.c.

Fig. 48, Oosprore. Scherffel, l.c.

\section{Cyclotellae Scherffel, '25}

Fig. 49. Olpidium-like thallus undergoing cleavage.

Fig. 50. Zoospore.

Fig. 51. Oospore.

\section{Lagenidium sp. Couch, '35}

Fig. 52. Lagenidium sp., in Oedogonimm. Couch, l.c. Fig. 53. Diplanetic zoos]ores.

\section{L. giganteum Couch, '35}

Fig. 54. Portion of filamentous thallus.

Fig. 55. Vacuolate content of sporangium shortly after emerging.

Fig. 56. Early stage of sporogenesis; flagella arising adjacent to peripheral vacuoles.

Fig. 57. I ater contracted stage following disappearance of central vaeuole; peripheral vacuoles incorporated in the zoospores.

Fig. 58. Zoospores in a resicle.

Fig. 59. Various views of the zoospores.

$$
\text { L. zoophthorm Sparrow, '39 }
$$

Fig. 60. Lobed thallus in rotifer egg.

Fig. 61. Emergence of zoospores.

Fig. 62. Zoospore. 


\section{PI,ATE 20}

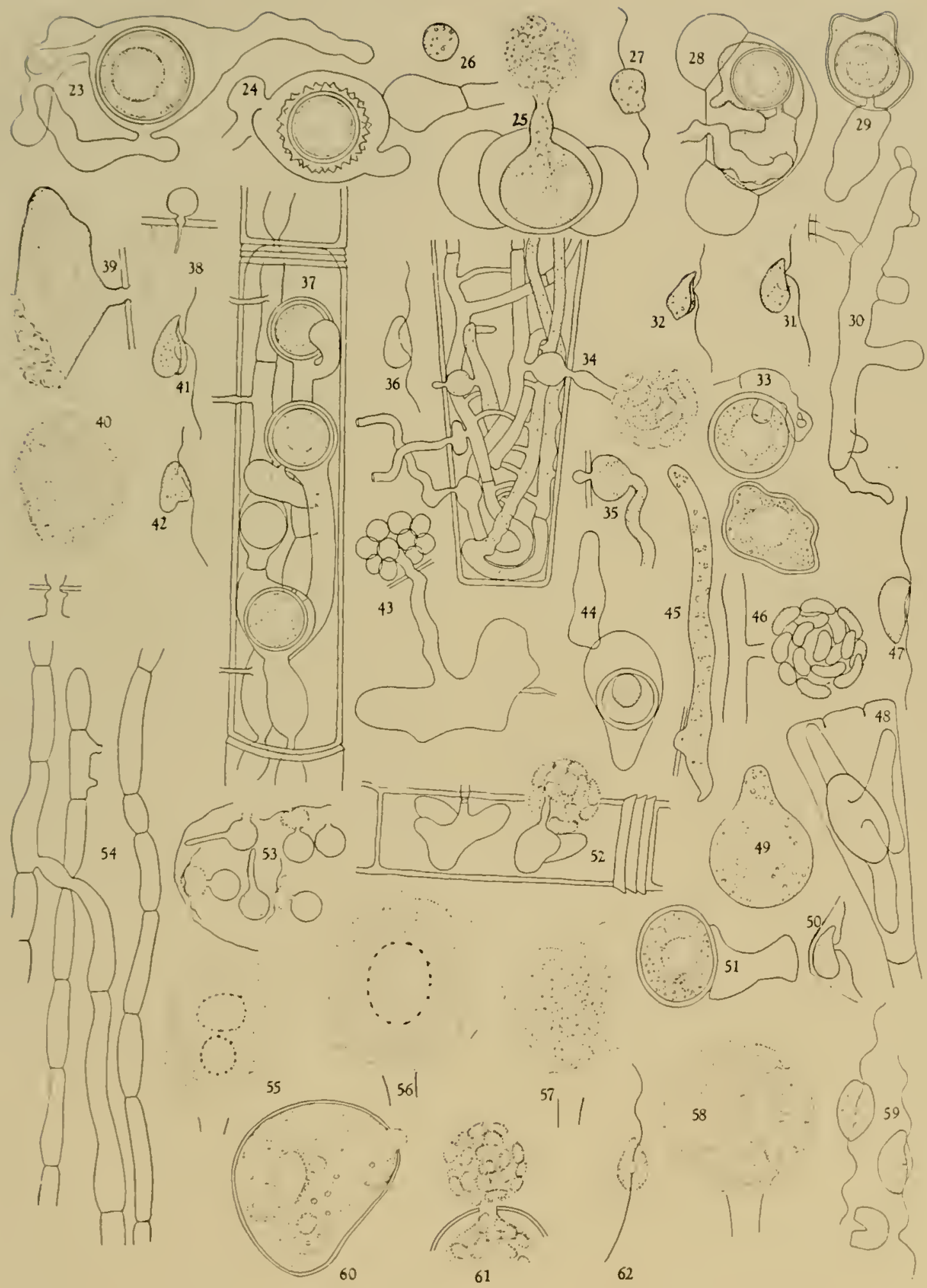


and enerst (fig. 43), later germinating and leaving a hyaline shell behind as in Achlya, Ectogella, etc. Diplanetism has also heen shown by Scherffel and Couch to occur in L. enecans and Lagenidium sp. (figs. 52.53). It is thus obvious that species of Lagenidium may exhibit a wide range of variation in place and time of sporogenesis and zoospore behavior.

The zoospores are generally described as beanshaped. but in species which have heen critically studied this appears to be the initial shape only. As they grow older they become more pyriform and reniform with a pointed anterior and a rounded posterior end and a ventral groove. The flagella are inserted laterally in this depression, and in most species they have been figured as equal in lcngth. The secondary swarmers in $L$. enecans and $L$. Oedogonii (figs. $31,32,41,42$ ), however, are heterocont with the shorter flagellum extending forward, according to Scherffel ('25), but in Lagenidium sp., Couch illustrated then as isocont (fig. 53). Their method of swimming is rather smooth and regular in contrast with the darting movement of the chytrid swarmspores, and in this respect they are very similar to those of Achlya, Saprolegnia, etc.

The antheridia and oogonia may occur in the same thallus and among the sporangia (fig. 16) or in separate thalli. The elongate multicellular thalli more often hear both gametangia. In the small unicellular specics the thallus is usually divided by a transverse septum into two cells at maturity, which become the so-called antheridia and oogonia, respectively, while in other reduced species conjugation may occur between separate uniccllular thalli. Species in which both gametangia are horne on the same thallus have been generally referred to as monoecious, while those in which the respective gametangia are horne on separate thalli are regarded as dioecious. It is not known and has never been demonstrated, however, whether the so-called dioecious thalli have arisen from zoospores of the same or different sporangia and thus represent distinctly male and female strains. Until monozoospore studies have been made and it has been shown that such thalli possess the potentialities of only maleness or femaleness or both, it is premature to describe some species of Lagenidinm as heterothallic or dioecious.

The so-called oogonium nay be elongate, spindleshaped, oval, ellipsoidal, ajmost splicrical, locally pannchy, and irregular, with or without conspicuous protuberances. The antheridium is usually smaller, more elongate and cylindrical, but varies somewhat in the different species. In $L$. rabenhorstii, $L$. marchalianum and $L$. enecans it is relatively slender and cylindrical like the vegetative filaments. In L. Cyclotellae and L. Oedogonii it is usually slightly smaller than the ongonium and not particularly different in shape. In most species it forms a conspicuous perforation or conjugation tube--i.c., L. rabenhorstii (fig. 14), L. marchalianum (fig. 37), L. enecans (fig. 333), etc, while in the smaller species, L. Oedogonii and L. Cyclotellae, the tube is not very evident, according to Scherffel's drawings (figs. 44, 51 ).

Zopf's description of fertilization in $L$. rabenhorstii is the only careful and detailed account of the process for the whole genus. After the conjugation tube lias pierced the oogonium wall, the gramular refractive protoplasm of the antheridium contracts into a globular mass and accumnlates at the side adjacent to the oogonium (fig. 12). Shortly thereafter it begins to flow into the latter, and after approximately three hours the process is completed (figs. 13, 14). While this is going on the ooplasm begins to contract toward the tip of the conjugation tube, and at the same time the granules, hodies, and discrete elements of the protoplasm undergo visible movements. As the contraction continues the ooplasm becomes more and more coarsely granular, and by the time the antheridium is empty, the granules have coalesced into two large refringent globules (fig. 13), which later usually fuse into a single larger one (fig. 14). Fusion is then complete, and eventually the zygote becomes invested with a thick wall.

It is to be particularly noted from Zopf's account that no egg cell and periplasm are differentiated prior to fusion as in the Saprolegniales and Peronosporales, respectively. The contraction of the ooplasm during plasmogamy, however, may perhaps foreshadow this development. Cook ('35), on the other hand, described the formation of an egg cell with a definite wall prior to fusion in L. rabenhorstii, and in his treatment of the whole genus he frequently referred to the presence of an oosphere. His figures, however, are not very clear and convincing, and in the writer's opinion the presence of a welldifferentiated egg cell remains to be shown.

In parthenogenetic species the antheridium is lacking, and the ooplasm contracts, rounds up and becomes invested with a thick wall. Germination of the oospores has been reported only in one species. In $L$. rabenhorstii this occurs within 24 hours after fertilization, according to Cook. "The wall of the oospore breaks dow and a single zoospore is liberated, which . . . is ahmost spherical in shape, $8 \mu$ in diameter and is provided with two large flagella" (fig. 17). He described this motile cell as a sexual zoospore in contrast to the asexual zoospores produced in sporangia. Inasmuch as nothing is known about the time and place of meiosis as well as sex determination in Lagenidium, Cook's use of the term sexual in this relation is obvionsly premature and unwarranted.

So far no cytological study of fixed and stained material has heen made of the genus. Accordingly nothing is known about mitosis and the details of cytokinesis. It also remains to be seen whether the gametes arc uni- or multinucleate at the time of fertilization, whether karyogamy immediately follows plasmogamy, and at what stage meiosis occurs. Such problems must first be solved before the relationship of Lagenidium with the higher Oomycetes becomes clear. 


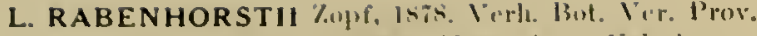

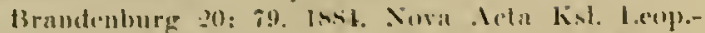

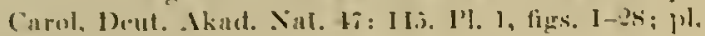
2. figs. I-9.

'Thallus usually elongate, filinnentous, tulular, lyphatlike when youngr. becoming septate, thicker, a-s $\mu$. vesicular and more irregular. curved, and crooked. witl several short brancle's and protulerances: frequently attached to the host cell by the infection tulye and goospore cise': contined to single cell or extending inte adjacent host cells; usually slightly eometricted at the septas scigments clongate, $10-20 \mu$. cylindrical and often irregular. sometimess breaking apart and separating : dwarf thalli nsually unicellular and often Olpielum-like. Sporangia of the sime size and blape as the thallus segments with one straight. curved or tortuous, narrow, rarely constricted exit tulec, $2-3 \mu \times 5-20 \mu$. which docs not project very far heyond the surface of the host; content of sporangium emerging and undergoing cleavage into zoospores ontside of host: resicle present. or doubtful. Zoospores at first bean-shiaped, later becoming more prritorm and reniform, $6 \times 8.5 \mu$. isocont. Gametangia horne on the same or different thalli; oogonia terminal or intercalary, spindle- and egg-shaped. locially paunclyy and irregular or almost spherieal, up to $15 \mu$ in diameter; antheridia unually clongate and cylindrical, $5 \times 15 \mu$, or somewhat irregular: sometimes horne on a delimited branch from the oogonial cell, usually on an adjacent, or interealary cell : developing a protuberance toward the oogonium which elongates and tapers into a perforation tube and pierces the oogonial wall; granules. bodies and diserete elements of the ooplasm undergoing slight morement, and the whole content contracting during plasmognmy ; fused protoplasts contracting further and becoming invested with a wall. Oospores spherical 10-15 $\mu$, hyaline, smooth, thick-walled with a large central refiative globule; germinating within 24 hours hy giving rise directly to a large spherical $8 \mu$, biflagellate zoospore $(\vdots)$. which soon infects the lost cell.

Parasitic primarily in the vegetative cells of spirogyra sp.. Mougeotia sp.. and Mesocarpus sp. in Germany (Zopf, l.c., '79) 11 inden, '11); Spirogyra sp. in Belgrum (de Wildeman. 91,93, 95) and Roumania (Constantineanu. '0t); Oedogonium sp. in Denmark (Petersen. '09, '10); Spirogyra sp. in Sew York and Mass., C.S. A. (Atkinson, 09 ; Sparrow. '32): Oedogonium pluciosporum and S. orthospira in Iontana, U. S. A. (Graff, '28); Spirogyra sp. and Mongeotia sp. in Bulgaria (Valkanor, 'i1); Spirogyra sp. S. mirabilis and Zyynema sp. in Hungary (Ceju, '35: 1)omjan, '35). Spirogyra sp. in Fingland and Wales (Cook, '32, '33. '35). 'The writer also has freguently found it in sipirogyra sp. and Oedogonium sp. in lew York City.

Investigators are divided in their observations and opinions alout the presence of a resicular membrane around the roung zoos pores in this speceics. Zopf and sparrow reported that zoospore cleavage and development accur within a vesiele, like in l'ythium, lout Atkinson and Cook ('\$5) deseribed the exuded protoplasmice mass as naked. In a previous piaper ('32). however. Cook had reported the appearance of at thin membrane, while ligure 9 and plate 1 of his 1935 contrihution are very' suggestive of its presence. Atkinson further described fusion of zoospores. but this appears to be an almormal and prossibly pathological belavior and apparently has no sexusl signifieance.

Cook ("35) maintained that the content of tile oogonium contracts and becomes invested with it wall before fusion. forming thus a definite ousplere or cog cell which is attached to the oogonium wall hy a stalk. Zopf, on the other hand, who carefully watched the successive stages of fusion at diflerent time intervals reported that contraction does not occur previous to but during plasmogamy and that a wall or membrane is formed only after the process has heen completed. Cook's figure and description of fusion are not particularly clear, and what he deseribed as an oosphere attaehed by a stalk seems to he a fertilized oospore and a conjugation tuhe (figr. $15)$.

Whether or not Cocconi's ('9h) L. papillosum is identical with this species is uncertain. Saccardo ('88) and Minden (11) regarded it as related, while Cook believed it to be an incompletely described specimen of $L$. rabenhorstii. According to his calcullations of Cocconi's drawings, the thallus is about $5 \mu$ in diameter, the sporangia $17 \mu$, zoospores $4 X$ $6 \mu$ oogonia $16 \mu$, and the oospores $10-12 \mu$ in $d i-$ ameter. The oosfores, however, have a distinctly warty wall, while the zonspores are figured as pyriform with two equal anterior flagella. Cocconi's drawings of the zoospores, however, may possibly be inaceurate. It is to be noted in conncetion that in his early papers ('78, 79) Zopf also descrilued the oospores of $L$. rubenhorstii as being golden in color and warty but these observations possibly relate to I.. entophytum.

L. ENTOPHYTUM (Pringsheim) 7.ppf, l.c., p. Ijl: pl. 2 , figs. 10-18; 14. 3. figs. 1-3.

Py/hium entophytum Pringshein, 18.58. Jahrb. W'iss. Bot. I : 287, 30.5. Pt. : fig. I.

L. Imericumum Atkinson, 1909. But. Gaz. 48: 331. Fig. ti.

'Thalhus tubular, resicular, short, relatively thick. 1-8 $\mu$, curved, crooked and very irregular witls mmerous sloort primary, secondary and tertiary branches or protuberances; usually constricted slightly at the cross septa d dwarf thilli continuous. Sporangia of the same size, $5 \times 12-15 \mu$. and shape as the thallus segments and dwarf thalli, exit tulses munerous, up to 20 or more. cylindrical and tortuous, $2 \mu$ or more in diameter and of varialble length, usually inflated hefore passing through loost wall, and extending considerably leyond it contents of sporangia emerging and forming an irregularly glolyular mass at the mouth of the exit tube, which may somctimes float away hofore dearage is completed; vesicular mombrane doulitful or alsent. Zooypores hean-shaped and reniform, $k \times 8 \mu$, isocont. Oogro- 
nia locally vesicular or paunchy; antheridia lacking. Oospores numerous, parthenogenetic, formed by the contraction and encystment of the oogonium content; spherical, $12 \mu$, with a bright-golden, thick, smooth or warty wall, and a large central refractive globule; germination unknown.

Parasitic in the zygospores of Spirogyra sp. (Pringsheim, Zopf, 1.c.), Euastrum humerosum and Microasterias mahabuleshwearensis var. wallichii (Schultz-Danzig, '23) in Germany; Spirogyra sp. in Belgium (de Wildeman, '91, '93,'95); S. varians, $S$. calospora, and $S$. insignis in New York. U. S. A. (Atkinson, l.c.), and Spirogyra sp. in Wales and England (Cook, '33,'35).

This species appears to have been described and figured first by Carter (' 56 ; pl. 9, figs. 9-10) as a develojmental stage of an Astasia-like flagellate in the zygospores of Spirogyra, and later by Pringsheim as a specics of Pythium. It differs primarily from $L$. rabenhorstii by its shorter, thicker, more crooked and irregular thallus, parthenogenetic oospores, and its lacalization to the zygospores of the host, although de Wildeman ('95) claims that $L$. rabenhorstii also may occur rarely in zygospores of Spirogyra. On the other hand, L. entophytum is strikingly similar to $L$. gracile which inhabits the same cells, and there is a strong possibility that the two species may be identical.

Pringsheim figured and described the zoospores of his fungus as being formed exactly as in Pythium within a definite vesicular membrane, but Cook reported that the latter structure is missing and that the extruded mass of protoplasm is naked. Atkinson likewise failed to observe a membrane and reported that the protoplasmic mass may float away from the exit tube before cleavage. Cook further regarded the contraction and encystment of the oogonium contents as the differentiation of an egg cell or oosphere as in $L$. rabenhorstii.

In view of the fact that no other workers have found this species in other hut Spirogyra zygospores it is perhaps questionable whether Schultz-Danzig's fungus in Euastrum and Microasterias relates to L. entophytum. His fungus may possibly belong to Petersen's Myzocytium irregulare or the unidentified species of Lagenidium reported by de Wildeman ('95) in Euastrum oblongum. Whether Atkinsou's $L$. americanum is identical to $L$. entophytum or L. gracile, or distinct from both is at present largely a matter of personal interpretation, but the author is inclined to agree with IInden that it relates to L. entophytum.

L. ENECANS \%opf, l.c., p. 154. Scherffel, 1925. Arch. I'rotistk. 5:2 : 20. 1'l. 2 , figs. 60-69.

Thallus sparingly branched with short plump, finger-like branches, $6-12 \mu \times 37-156 \mu$; attached to host cell by infection tube; apparently continuous, transformed completely into a zoosporangium at maturity. Exit tube cylindrical, $3-6 \mu \times 9-36 \mu$, extending only slightly beyond the surface of the host; thickened and inflated at base to form a "spreading "ipparatus" which enables it to pass be- tween the valves of the host cell. Zoospores egg- and kidney-shaped, elongate with a ventral groove, $5.7 \mu \times 8-12.5 \mu$; secondary swarmers heterocont with the short flagellum directed forward; vesicular membrane not clearly evident. Oospores spherical, $18 \mu$, broadly oval, I5-22 $\mu \times 20-24 \mu$, and irregular with a smooth thick wall, large central refractive globule, and finely granular protoplasm; germination unknown.

Parasitic in Stauroneis phoenocenteron, Cocconema lanceolatum and Pinnularia sp., in Germany (Zopf, l.c.); various diatoms in Belgium (de Wildeman, 93); Gomphonema constrictum, Cymbella cymbiformis var. parva, C. gastroides, Cymatopleura solea, Stauroneis phoenocenteron, Amphora ovalis, and Cocconema lanceolatum in Hungary (Scherffel, '02, '25); Navicula cuspidata var. ambigna and Stauroneis phoenoceuteron in China (Skvortzow, '31).

Inasmuch as Zopf and none of the subsequent workers except possibly de Wildeman had figured this species, Scherffel was not certain that the form whicb he found relates to $L$. enecans, although he described it as such.

L. PYGMAEUM Zopf, 1887. Abl. Naturf. Ges. Halle 17: 97. Pl. 1, figs. $21-39 ;$ pl. 2 , figs. 1-12.

Thalli usually solitary, sometimes 2-4 in a host cell, oval, spherical, ellipsoidal and Olpidium-like, or elongate, irregular and lobed with one or several short branches or protuherances; often completely filling the host cell; unicellular or dividing into an antheridium and oogonium at maturity. Exit tubes short, thick, tapering, and rarely hranched, usually extending but a short distance heyond the host cell. Zoospores hean-shaped, $5 \times 8 \mu$, tapering at the anterior and more rounded at the posterior end with a ventral groove and several small refractive granules; delimited in the sporangium, emerging in succession, and completing their development in an extramatrical vesicle; swarming in the latter and freed by its rupture; intermittently amoeboid. Oogonia oval, paunchy and slightly irregular with protuberances; intheridia smaller with none or fewer and less conspicuous protuberances; conjugation canal nsually well dereloped. Oospores predominantly spherical and oval, sometimes ellipsoidal and slightly elongate, 18-29 $\mu$ in diameter, hyaline, smooth, and thick-walled, with a large refractive globule; germination unknown.

Parasitic in pollen grains of $P$. sylvestris, $P$. austriaca, P. laricio, P. pallasiana, Pinns sp., and Cosmarium pyramidatum in Germany (Zopf, l.c.; Schultz-Danzig. '23). pollen grains in Switzerland (Maurizio, '95) and conifer pollen in Belgium (de Wildeman, '95) and Denmark (Petersen, '09, '10).

The author (' 11 ) collected this species in pollen of $P$. anstriaca in New York City and succeeded in transferring it to pollen of $P$. sylvestris, $P$. banksiana, $P$. densiflora, $P$. thunbergii, $P$. strobus, $P$. austriaca var. nigra and hemlock. Attempts were also made to infect living and killed cells of Nitella flexilis, Chara coronata, Cladophora glomerata, 
l'ithophora sp.. Stigeoclowium tenue, Clothrix zonata, ().dogonium sp.. Spiroyyra sp.. s. crassa, Mougentia sps.. and Mydrodictyon reficulatum without suceess. "l'hese results coist dombt on SchultyDanzig's report of the oceurrence of this species in Cosmarium. He hased his claim on the presence of an irregular. lobed. sac-like thallus with an exit tulue which is rarely hranched, and the presenes in the same culture of pollen grinins infested with $L$. p.ygmarnm. It is not improbible that his fungus relates to dwarf thalli of Myzocytium or another specic's of Lagenidium. Zopf's report that the zoospores are 16 to $18 \mu$ long is olwiously incorrect. The present writer has observed their formation and actirity numerous times and found them to he approximately $5 \times 8 \mu$ in sime and hean-shaped with a ventral groove.

Thalli of this species miy look strikingly like those of Olpidimm, and unless zoospore emergence is ohserved they may readily he mistaken for this ehytrid. Fischer helieved that the intramatrieal resting spores of $R$. pollinis noted by Cornu ('72, p. 121) relate to $L$. pygmaeum also. Atkinson ('09) belicred that the zoospores of $L$. pygmaeum species are diplanetic - the emergence of the incompletely dereloped zoospore segments representing the initial motile stage.

Whether Serhinow's ('99) Olpidium ramosum relates to this species or belongs at all in the gemus Lagurnidim is very doultful. Mention is nevertheless made of it here because it occurs in pollen grains of l'imus sylzestris in Russia and is reported to form oospores. However, the zonspores are fully formed in the yoosporangium, possess a single postcrior flagellum, and swim directly away after emerging from the hranched exit tuhes. In sexual reproduction two thalli, ipparently of unequal size, fuse within pollen grains and become invested with a thick wall. 'This type of fusion is suggestive of that which occurs in Olpidiopsis, but the presence of posteriorly uniflagellate zoospores excludes $O$. ramosum from this genus as well as from Lagenidium.

L. GRACILE \%pf, I.c., p. 158. Cuok, 1932, New Phyto]. 31: 1.40. 1 igs. 32-3\%, 193.). Arch. Protistk. 86: 88. Pl. 3, figs. $2(i-3)$.

Thallos very similar to that of $L$. entophytum but usually narrower, $+.5 \mu$, and less irregularly branched." sometimes penetrating adjacent host cells. Sporangia less irregular, tubular. cylindrical. 4.5 $\mu$ in diameter, and oceasionally alnost spluerical with a narrow unconstricted exit tube of viriable: length. whieh may lecome inflated hefore passing through the zygospore and gimetangium wall of the lost: extending for varying distances beyond. Zouspores bean-shaped, $+\dot{X} 7.5 \mu$, formed in an extramatrical resicle ( $(2)$; vesicular membranc doubtful. Oogonia intercalary, rarely terminal, oval, glohular, pauncly; ; antheridia lacking. Oospores few or mimerous, parthenogenetic, formed as in $L$. "utophytum, splerieal, 13-1. $\mu$, with a thick smooth wall; germination unknown.
Parasitic in the aygospores of Spirogyra sp. in Germany (Zopf, l.e.); S. grezrilleana in Belgium (de Wildeman. 95), and Spirogyra sp. in lingland (Cork. l.c.).

From the above description, the validity of this s]ecie's seems very questionable. 'l'he slight diflerences in diancter, irregularity of branching, lengtl and diameter of exit tules, ete.. noted by Zopf and subsecpuent workers are not suflicient to distinguisl it sharply from L. erutophytum, and inasmuch as both are parthenogenic and inhabit the aygospores of Spirogyra, the author is strongly of the opinion that they are identical. Zopf's claim that the oospores differ liv being smooth and not liright golden in color does not seem particularly siguificant, since such oospores have heen reported in $I$. entophytum ilso.

L. ZOPFII de Widenan, 1891. Bull. Soc. Belge Miero. 16: 139. Petersen, 1909. Bot. Tidskr. 9: 401. Fig. XV1b.

'Thallus irregular, branched, septate; consisting of elongate, cylindrieal and resicular segments, and extending through $3-4$ host cells. Sporangia and zoospores unknown. Oogonia vesicular and paunchy; oospores $14 \mu$ in diameter with an irregular warty wall; content refractive, large globule lacking; germination unknown.

Parasitic in Oedogoninm sp. in Belgium (de Wildeman, l.c.) and Iutland (P'tersen, '09,'10).

This speeies has been reported hut twice, and Petersen's single figure of it is the only one extint, as far as the writer is aware. De W'ildeman ('93, p. 11) and Minden ('11) believed it may possihly be identical to $L$. syncytiorum described below, and Cook ('35) listed it as a synonym of the latter species. However, if the two are identical, $L$. syncytiorum should be the synonym, since $L$. zopfii las priority. While the author is inclined to agree with the riew at present that they may he identical, botlu species are too incompletely known to warrant definite conclusions. For this reason they are herewitl treated as distinct species for the time heing. According to de Wildeman, the thallus is similar to that of $L$. rabeuhorstii, but P'eters'n described it as narrower and less liranched. The onspores, on the other hand, resemble those of $L$. entophytum.

L. SYNCYTIOR UM Klehahn, 1892. Jahrl,. Wiss. But. 24: 263. 1’1. 3, figs. 22-24.

Thallus at first straight, 3-5 $\mu$. irregular, curved, heady, filamentous and continuous; later beconing septate and more irregular with mumerous protuherances; extending through several incompletely divided host cells. Thallus segments and sporangia splacrieal, oval, cllipsoidal, $8-10 \mu$ in diameter. spindle-shaped. elongate, conred and somewhat irregular with a single short exit tulue which does not projicet very far beyond the loust cell. Zoospores, oogenial, antheridia and oos jores unknown.

Parasitic in Ordogomium bossii in Germany (K'le-

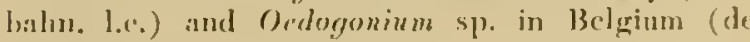
Wildeman, "(95). 
This species has been reported lut twice, and is so incompletely known that it is impossible to determine whether or not it is identical to $L$. zopfii. De W'ildeman, however. was inclined to regard the fungus which he found at Nancy as distinct from L. zopfii and possibly related or identical to Sorokin's Aphanistis pellucidia. It is to be noted here. however. that the zoospores of the latter species are uniflagellate, according to Sorokin.

According to Klebahn, L. syncytiorum has but little deleterious effect on the host cells at first. Nuclear dirision may proceed normally for a time. but cell division is not completed. As a result, infected cells may be multinucleate witl incompletely formed cross walls, and 2-4 times their normal length. In these respects the effects are very similar to those caused by Plasmophagus in the same host (de Wildeman. '95. p. 220). De Wildeman, on the other hand, failed to obscrve the effects described by Klebalm, and found that the thallus may be confined to a single cell the content of which it soon destroys. According to Klebahn, all host nuclei in infected cells are not similar in size and shape. Some may be large while others are quite small. suggesting perhaps a previous disturbance in cliromosome distribution. As the parasite matures the effects on the host become more pronounced. The plastids, nuclei, and the remainder of the protoplasm are gradually killed and largely absorbed.

The irregular thalli of this species resemble somewhat those of $L$. ellipticum, while those in w' ich t'se segments are arranged like a string of heads lock similar to thalli of $M y z o c y t i u m$ megastomum.

L. ELLIPTICUM de Wildeman, 1893a. Ann. Soc. Belge Ulicro. 17: 5. Pl. 1, figs. 1-11. 1893b. Jour. Roy. Micro. Soc. 1893: 765 .

Thallus thick. deeply lobed and irregular with numerous blunt protuberances, rarely becoming filamentous, non-septate and continuous with one or more short exit tules which project only slightly berond the surface of the host. Zoospores, oogonia and antheridia unknown. Oospores elliptical, 10-1. $X$ 20-30 $\mu$, with a thick irregularly warty wall, and a granular refractive content; germination unknown.

Parasitic in rhizoids of mosses in Belgimm.

De Wildeman was not certain about the relationship of this species to Lagenidium, and in view of the fact that no zoospores, ongonia and antheridia have heen ohserved it is herewith presented as very doultfful. The oospores are usually numerous, but de Wildeman did not deternine whether or not they are partlenogenetic.

L. CLOSTERII de Wildeman, 1893b. Ann. Soc. Belge 11icro. 1\%: 4?. Pl. 6, figs. 1-j.

Thallus mycelium-like. consisting of long, straight, curved, twisted, hranched, cylindrical filaments of more or less uniform. 1.8-2.8 $\mu$, diameter; occasionally swollen, resicular, and irregular, usually unconstricted; becoming septate at maturity; segments transformed into sporangia or gametangia.
Sporangia elongate and cylindrical; exit tuhes greatly inflated, globular and appressorium-like inside of host wall and extending a short distance or 20-30 $\mu$ beyond its surface. Zoospores hean-shaped, $3.8 \mu \times 5.6-6.3 \mu$; formed in an extramatrical resicle. Oogonia inflated and broadly spindle-slaped. antheridia less so. Oospores spherical $10-15 \mu$, with a double-layered wall, exospore warty, verrucose or knobbed; germination unknown.

Parasitic in Closterium striolatum in Belgium (de Wildeman, l.c.); Closterinm sp.. in Denmark (Petersen. '09. '10). Czechoslovakia (Cejp, '33, '35) and North Carolina. U.S. A. (Couch, '35).

The warty or verrucose oospores of this species are very similar to those of $L$. entopliytum and $L$. zopfii, but differ from those of these two species by the possession of a large central refractive globule, according to de Wildeman. Minden regarded this species as doultiul, but Conch thought it may be valid. The latter worker pointed out that it may readily be mistaken for a species of Pythium because of its fine. filamentous thallus, but the large refractive granules in the cytoplasm, however, distinguish it rather clearly.

L. INTERMEDIUM de Wildeman, 189.5. Ann. Soc. Belge Nlicro. 19: 96. Pl. 4, figs. 10-13.

Thallus irregular, rather thick, frequently branched and sparingly septate. Sporangia tubular. elongate and cylindrical with a single exit tube which may be rarely inflated inside of the host wall, constricted as it passes through. and extends a short or long distance heyond the surface of the host. Zoospores, oogonia and antheridia unknown. Oospores globular, smooth and thick-walled; germination unknown.

Parasitic in Closteriam chrenbergii in Belgium (de Wildeman, l.c.); Closterinm sp... and Pleurotaenium trabecula in Bohemia (Cejp, '35).

This species las been observed but twice and is imperfectly known. Cejp did not add anything of significance to the original description of de Wildeman. $B y$ its elongate and cylindrical segments this species resembles $L$. rabenhorstii, and according to de IVildeman it stands intermediate between the latter species and $L$. entophytum.

De Wildeman (1.e.. p. 75 ; pl. 2 , fig. 22 ) also figured an extensively lohed parasite in Euastrum oblongum which he believed relates to Lagenidium. He did not, however, observe the zoospores and oospores, and hence it is difficult to determine the identity of the species. He, nonetheless. believed it may he the same fungus which Reinsch ('78, pl, 17 . fig. 5) figured in $E$. oblongnm. Cornu ('77). however, belicred Reinsch's fungus relates to $1 y y z o c y-$ tium lineare.

L. REDUCTUM (de Wildeman) nov. comb.

Lagruidiopsis reducta de Wildeman, 1896. Ann. Soc. Belge Miero. 20: 109. Pls. 6-7.

Thallus filamentous, elongate, tubular, cylindrical. straight, curved and undulate, slightly inflated 
at the conds, rarely branched, eontinuous and unice?lular with the short infeetion tube and zoosjore case persistent. Sourangia and zoospores unkuown. ()ogenia crlobulatr. oval and almost splerical; hegriming as a terminal or intorealary swelling and with further arewth becoming somewhat lateral in position but continuous with the main axis. Antheridia oral, elavate, and cone-shaped: borne on the mogonium and delinited from the latter hy a cross wall: usually disintegrating and disalpleariug after fertilization: (omjugation tuhe usually well-eleveloped and conspicuous. Oospores single. rarely double, spherical, oval, ellipond and cgg-shaped. $13-19 \mu$ in dianeter, with a thick rough or warty wall: content granular with one or more refractive slohules: germination unknown.

Jarasitic in the oogonia of Chara in Switzerland.

De Wildeman created the genus Lagenidiopsis as an intermediate group between the l.agenidiales and Peromosporales, primarily because the thallus is filamentous and unicellular. These characters, howcver. arc no longer of signiticance in this case. since similar thalli lave subsequently hecn found to be - Haracteristic of certinin species of Lagenidinm also. Furthermore, the method of sexual reproduction in Iagenidiopsis is trpical of that in the former genus, and on these grounds it secms logical to merge the (wo) genera. Their identity or difference, however. cannot be definitely settled until the sporangia and \%oospores of Lagenidiopsis lave been found.

L. MARCHALIANUM de Wildeman, 1897. Ann. Soc. l3elge .1 icro. :1: 8. 1'l. 1, figs. 1-9.

Thallus filamentous, cylindrical, $2.2-6.7 \mu$ in diameter, sometimes irregularly swollen, slightly or not at all constricted; occasionally confined to a single cell, but usually extending througl six or seven host cells: cularged up to $7 \mu$ in diameter before entering the cross septil of the host and constricted to $1 \mu$ as it passes through. Sporangia cylindrical. clongate. 30-60 $\mu$, narrowly spindle-shaped with a delicate, $1.5-2 \mu$ thick, exit tube whichextends $1-5 \mu$ beyond the host eell. Zoospores unknown. Oogonia spherical, $20 \mu$. intercalary, rarcly terminal; antheridia adjacent to oogonia on the same filanents, or arising as a branch from an adjacent filament. Oospores spluerical, 8-1 $4 \mu$, hyaline, smooth, thickwalled, rarely partlenogenctic; germination unknown.

Parasitic in Oedogonium sp). in Belgium (de Wildeman, l.e.) and Virginia, L.S.A. (Couch, '35).

L. OEDOGON1I Scherffel, 1903. Hedwigia 11: (10.5). 19:5. Areh. Protistk. 52: 109. 1'l. 5, fizs. 209-219.

Thallus usually single, rarely two or more in a cell, ovoid, vesicular, $20-25 \mu \times 3.5-50$ - $\mu$. irregular, lobed. witl blunt protuherances, rarely filamentous, filanents when present several humdred microns in length and coiled; non-septiste and continuous with onc exit tulue which nay cud alunost flush with the urface of the loost cell or extend considerably beyond it. Zousprores mono- or diplanctic: fully formed in the sporangium or delimited in an extramatrical vesicle wilh an indistinct membrine: in the former case energing singly and encysting in a group at the month of the exit tuhe, later germinating and leaving the p-6.6 $\mu$ in clinneter. cysts hehind as in . $/ \mathrm{ch}$ lya; secondary zoospores or swarmers pointed at the anterior and rounel at the posterior end with a ventral groove, heterocont with the short fligellum directed forward; forming an apjoressorium on the host wall in gemmination. Oospores glolular, spheri(a), l-2-1+ $\mu$, with a $2 \mu$ thick. hyaline, smooth wall and containing coarsely granular protoplasm and a lisge eccentric globule: germination unknown.

Parasitic in Oedogonium s]). in Hungary (Scherffel, l.c.) and Missouri, U. S. A. (Couch, "35).

'This is a significant species because its zoospores exhibit several characteristics common to $P y$ thium and Ichlya. The zoospores may be formed cxtranitrically in a resicle as in l'ythium, or within the sporangium and then emerge and encyst at the mouth of the exit tube as in Achlya. It is to be noted in this connection that the zoospores of $O l$ pidiopsis Oedogoniorum have the same characteristics. while it.s resting spores and their method of formation are also strikingly similar to the oospores of $\mathrm{L}$. Oedogonii. Scherffel accordingly pointed out that $O$. Oedogoniorum has nuch in common with Lagenidium, and was of the opinion that it may relate to the latter genus. From his drawings and descrijtions of the thalli one might believe that the two species are closely related or even identical, but the clongate thalli of $\dot{L}$. Oedogonii which Couch figured are distinctly unlike those of Olpidiopsis. It is nevertheless olvious that further study and comparison is very essential to an understanding of the two species.

In this species Scherffel found segments of the thallus or possibly of sporangia the contents of which had contracted. become septate, and thichwalled. He regarded these resting structures as comparalle with the gemmae of the Saprolegniaceae. hut it is doubtful that they are of any particular morphological or phylogenetic significance.

\section{SACCULOIDES Serbinow, 1924. Ia Defonse des l'lantes 1 : 8.j.}

Thallus short, unicellular. sic-like with lohes or slowrt branches, or narrowly elongate. 3.5-7.6 $\mu$ in diancter. with oceasional septa. Zoospores apparcntly completing their derchopment in an extramistrical resicle: spherical, 3.5 $\%$. in tixed and stained preparations; position and relative lengths of $\mathrm{H}_{\mathrm{a}}$ gella and presence of diplanctism unknown. Sexual reproduction isogamous; contcnts of two adjacent cells flowing together and forming a zygospore (?) in the space between them. Zyesspores livaline. spherical, $13.3 \mu$, oval, clongate, $7.6 \mu \times 15.2 \mu$, with a seulptured outer and a smooth inner wall: containing a large refractive glolule; germination unknown.

Parisitic and saproplevtic in ('losterium ralfsii var. hybridum in the Mlenzelinsk district of the Cifusk province in Russia. 
Serbinow's study of this species relates to material collected in 1913 and fixed in glycerine jelly. Consequently the method of zoospore formation, motility and behavior of the zoospores, relative lengthis and position of the flagella, as well as the successive stages of sexual reproduction were not observed. Whether or not it belongs in Lagenidium is questionable. Because of the lack of or reduced branching of the thallus Serbinow regarded it as intermediate between this genus and Myzocytium. Its method of sexual reproduction, howerer, seems strikingly similar to that deseribed by Dangeard for Resticularia nodosa. Until more is known about $L$. sacculoides, its relationship to the above-mentioned genera will remain doubtful. Serbinow did not illustrate this species, as far as the present writer is aware. Its effect on the host is quite marked. It kills the desmid cells very quickly and soon destroys their contents, but it is not an obligate parasite, according to Serbinow. It may also attack dead and partly empty cells.

L. CYCLOTELLAE Scherffel, 1.c., p. 18. Pl. ^, figs. 49-59.

Thallus snall, sac-like, and continuous, attached to the extramatrical persistent zoospore case by the germ or infection tube; transformed completely into a single sporangium at maturity, with a short, $3 \mu$ wide exit tube. Zoospores fully formed in the sporangium; emerging singly and swimming directly away; oval, egg-shaped. $3.5 \mu \times 6 \mu$, slightly concave with a refractive mass near the posterior end; flagclla attached slightly below the apex. Oospores glolose, $10 \mu$, broadly oval, $8-10 \mu \times 10-12 \mu$, angular and somewhat irregular, hyaline, smooth, thick-walled; containing a large refractive globule, granular protoplasm, and a lateral spot; germination unknown.

Parasitic in Cyclotella kutzingiana in Hungary.

The manner of zoospore formation and emergence in this species are very similar to those of $L$. pygmaeum and $L$. oophilum. In shape and appearance, however, the zoospores are more like those of Ectrogella bacilliariacearum, according to Scherffel. He did not observe diplanetism but believed that it occurs. Scherffel regarded this species as a connecting link between Ectrogella and the Lagenidiaceae (Ancylistaceae).

L. BRACHYSTOMUM Scherffel, 1.c., p. 21. Pl. \&, figs. $70-85$.

Thallus elongate, $4-7.5 \mu \times 150-250 \mu$, usually' unbranched or with short side branches and protuberances; continuous, and transformed completely into a single sporangium at maturity with one or rarcly two very short, tapering cone-shaped exit tulbes, the wall of which is greatly thickence at the base to form a sprcading apparatus. Exit tubes forcing the ralres of host cell apart, horing through the wall. Zoospores kidney-shaped with a rentral groove, $4 \times 6-8 \mu$, formed in an cxtramatrical resi- cle as in Pythium. Oospores formed parthenogenetically or by sexual fusion, globose, broadly-oval, $6-10 \mu \times 11-24 \mu$, hyaline, smooth, thick-walled with one or two large refractive globules; gernination unknown.

Parasitic in Synedra ulna, Cymbella cymbiformis var. parva, Gomphonema constrictum and Nitzschia linearis in Hungary (Scherffel, l.c.) and Synedra sp. in North Carolina, U. S. A. (Couch, '35).

This species differs from $L$. enecans, according to Sclierffel, by its unbranched thallus, thin wall, short, cone-shaped exit tubes, and the fact that it parasitizes small diatoms. As lie pointed out, however, it may also occur in Cymbella cymbiformis var. parza, which is also often parasitized by L. enecans. Many of the structural differences which Scherffel described above may possibly be due to the smaller hosts in which this species lives and do not relate to fundamental specific characters. Until extensive cross inoculation experiments have been made, the validity of $L$. brachystomum must be regarded with question.

Scherffel (1.c.. p. 23; pl. 2, fig. 86) further described a species of Lagenidium with a long sparingly branched, multiseptate thallus in Pinuularia sp.. which bears some resemblance to $L$. rabenhorstii. The exit tubes are fairly long and cylindrical and extend for some distance beyond the surface of the host cell. No zoospores nor their method of formation were observed. The oospores are solitary, globose and appear to have arisen by sexual fusion. Scherffel was doubtful about whether this species is homo- or heterothallic, but he felt certain that it is not identical to L.enecans.

L. GIGANTEUM Couch, 1935. Mycologia 27: 376. Figs. $1-19$.

Thallus coarse, extensive and mycelioid, branched, constricted or unconstricted; extramatrical branclies somewhat fine and delicate. Sporangia elongate and cylindrical, 6-40 $\mu \times 50-300 \mu$, with a single, long 6-10 $\mu \times 50-300 \mu$, exit tube; content emerging through the tube to form one or several globular, naked and undifferentiated masses, which undergo cleavage into zoospores. Zoospores slightly oval, $8-9 \mu \times 9-10 \mu$, with a ventral groove in which two equal flagella are attached; frecd by the rupture or deliquescence of the resicular membrane. Monoplanetic and rather sluggish. Sexual reproduction unknown.

Weakly parasitic on mosquito larvae, copepods and Daphne in Virginia, U. S. A. (Couch, l.c.; Mattlews, '35) and mosquito in North Carolina, U.S. A. (Couch, l.c.).

Couch succeeded in growing this species on various syuthetic culture media and isolated what he believed to be a mutant of the original strain. His is the first report of the culture of a species of Lagenidium apart from its host tissues. Since sexual reproduction has so far not becn olserved, Couch was somcwhat in doubt about whether this species re- 
lates to Lagenidium. It dillers from any of the other specin's in heing a weak laculative parasite and laseing an extemively branched filamentons, myceliond tliallus.

Another midentitied species has been recorded loy Cunch ( 33.5, p. 3s.5, figs. :32-35) in Oedoyonium which lie fouk to he L. brachystomum. "l'he thallus is oroid aml slightly irregular. $7-10 \mu \times 15-20 \mu$. The zenspores are formed in an extramatrical resicle. and after swimming alout for a short while. encyst. Within one to lhree hours the enereac and become metile anain. In rare cases eneysted spores which have greminated with a tule comerese, leaving the germ tule and cyst helhind. No stage's of sexual repruluction nor onspures have hee'n olserved.*

L. OOPHILUM Sparrow, 1939. Mỵenlongia 31: 531. Figs. $1-1 t$.

La!!enn on hhilum sparrow. l.c.

Thallus solitary or several in a lost ecll, irregularly saceate. ellipsoidal. broadly lobed or nonIohed: romserted holocarpically into a thin-walled livaline zoosporangium, 1:2-25 $\mu$ wide hy $20-40 \mu$ long. with a short sessile or slightly prolonged exit papilla. $1-5 \mu$ in dimmeter. Zoospores grape seedGlaped, literally hitlagellate, isocont. $6 \times 8 \mu$. cmeruing individually and maturing in a globular grmul at the exit orifice, resicle doublful or unkuown: erstospures $5-6 \mu$ in dimmeter. Sexual reproduction unknown.

" Since this vulume went to press another species of Largudium has bern rejorted and deseribed by Coueh in the eggs and newly-hatchet individuals of the common blue crath in Virginia. It is the on] known marine speeies of this genus and is characterized hy a course, braneluel. sparingly septate mycelium, a persistent pesicle. and asexual resting spores. Its mycelium is very similar to that of $L$. gigumer $u m$. and Conch belieses that the two species are closcly related. Unlike the latter suecies, lowiever, it will not grow on nutrient agar malle with fresh water. Its economic significance as a plarasite is not known, lout it kills the infectrol cergs and young indisicluals. J'arasitized egfes of the Jost can be distinguished from normal ones by their smaller size and greater opacity:

L. CALLINECTES Courd, 1:42. Jour. Whisha . Mitchell Soi. Sue. 55: 15\%. PIs. J8. 19.

Thallus predominantly intramalrieal, myeclioid, conrse, irregularly branched, sparingly acptate, thin-walled, $5.1-12.6^{\circ} \mu$ in diametrer; each sogment becouning at spesangium. Fixtranat rical emergence papilla of sporangium tutular, $11-29 \mu \times 25-70 \mu$; protoplasm churging as an irregular, subspluerical or spluericil mass, up to $100 \mu$ in cliancter, and becoming enveloped by a persistent, thick, gelatinous envelope or vesjenlar meonbrane; alcaving into zouspores ats in Pylhium. \%oospores swarming in persistent vesiele and later liberated by its rupture; tapering at the anterior and rounded at the posterior cond. 9.fi $\times 12.6 \mu$ with a cliagonal growre; containing several oil [ulubules; isocont (E), flagella insurted laterally (:) in prowe and (extending in opposite dircetions in swimming; zouspores coming to rest and encysting, eystoupures oblonge or subupluerical, $10-11.3 \mu$; momoplanctic. liesting spores asexual, spherical, subs]werical or wal, Is-30 $\mu$, wills a $3 \mu$ thick wall; containing puld whitish protoplasm and an excent rie mass of oil getohules; frermination ursmown.

Parasitic in the eqgos and new]y-hatehol individuals of colliuertes sajudus in Virginia, $\mathcal{L}$. S. 1. l'arasitic in rotifer eggs and cmbryos, Huron River, Anu Arlwor, Michigan.

luasmuch as its sexual reproduction is unknown, the validity of this species is questionahle. Sparrow was doubtful ahout its identity, as is indicated hy the two names proposed above. He stressed the similarity of its unicellular vegetative thallus to those of $M_{y}$ zoeytium zoophthorum, L. Oedogonii, and Lagena radicicola, particularly when the latter's thalli are reduced. His suggestion of including this species in Lagena hecause of its unicellular thallus is not of much merit in light of 'Truseott's ('33) earlier ohservations that the thallus of $I$. radicicola may be greatly elongate, tubular and liranched. Obviously size and shape of thallus in this group of fungi are not always fundamental diagnostic characters. It may be noted lurther that L. oophilum also rescmbles L. pygmaeum in zoospore size as well as in sliape and size of thallus (Karling, ' 11 ). Cross inoculation cxperiments inrolving the respective hosts of these two species may. possibly show that they are identical. Sparrow made no attempt to grow his species on any hosts but rotifers.

The irregular, stout, $3-8 \mu$ in dianeter, branched thallus which Sparrow ('36, pl. 17, figs. 13-15) previously found in cysts of Euglena rescmbles that of Lagenidium and may possibly relate to this genus. Elliptical, $10 \times 13 \mu$, thick-walled resting spores were also olsserved in association witl empty thalli. Sparrow also believed that the irregular, immature thallus (pl. 19, fig. 16a) which he found in a dead nematode may belong in this genus.

In this connection it may be noted that Deckenbach ('03) found a marine species of Lagenidium at Balaclawa which parasitizes Chaetomorpha acrea. However, he did not describe or diagnose it and increly stated that it differs from the then known freshwater species hy its large size.

Two additional specics of Lagenidium (?) were reported by Scherffel ('26, 1. 216) in Oedogonium franliliniana and l'enium digitus but he did not identif $y$ them.

\section{MYZOCYTIUM}

Schenk, 1858. Über das Vorkommen Contractiler Zellen in Pflanzenreich, Wur\%burg, p. 10.

Bicricum Sorokin, 1883. Arch. Bot. Nord Franee 2: 43 .

\section{(1'LATKE 21, 2:2)}

Thallus intramatrical. holocarpie: unbranched. usually clongate. "ylindrical and continuous when young. later hecoming scplate and constricted: occanionally reduced to one or two seguents and becontung Olpidium-like. Zoosporangia formed directly from the scements of the thallus, oral, chlipsoid, spherical, elongate and cylindrieal, hyaline 
and smooth with one or two exit tubes of varying length which may projeet slightly or considerably bevond the surfaee of the host eell. Zoospores beanshaped with two flagella inserted laterally in a slight depression, and several small refraetive granules; partially formed in the sporangium, emerging in sueeession, and completing their development in an extramatrieal vesiele, or developing eompletely on the outside within a vesiele, and eventually rupturing the vesieular membrane. Gametangia formed in the same manner as, and of ten intermingled with, the sporangia; antheridia usually of the same size and shape as and alternating with the oogonia; no differentiation of egg cell, or oosphere and epiplasm prior to fusion; eontent of antheridia passing through a pore or small eonjugation tube into the oogonium; fused protoplasts contracting to form a spherical or globose oospore with a thin endospore, a thick smooth, stellate or seulptured exospore; containing one to several refraetive globules; germinating by becoming transformed direetly into a zoosporangium.

Mysocytium ineludes at present five species, two of which are doubtful. These speeies are parasites of desmids, green filamentous, fresh-water algae, nematodes and rotifers in Asia, Europe and North Ameriea. The development of the thallus is comparatively simple. As is shown in figures 3 and 4 , the zoospore beeomes attaehed to the host, develops a germ tube which penetrates the host wall and enters the lumen of the eell. The content of the spore passes into the tip of the tube, whieh then elongates, inereases in size, and eventually becomes the young thallus. It soon begins to absorb food from the host protoplasm and elongates further into a thiek, straight, eurved, irregular or lobed strueture whieh may often extend the full length of the host eell and even into an adjacent one. In the meantime, the zoospore ease and part of the gern tube disappear. At this stage the host protoplasm is usually elumped around the thallus and often obseures it, partieularly in $M$. proliferum (figs. $6,7,9,16$ ). By the time the thallus is mature most of the protoplasm has been absorbed. so that the host eell is almost empty, except for the parasite and a few extraneous granules.

In the early developmental stages the thallus is continuous, but as it matures it beromes septate and eonsists then of a linear series of eells. Aecording to Dangeard ('06) it is multinueleate from the early stages on. By further expansion of the individual segments, it usually lecomes constrieted at the septa, so that the thallus often appears as a series of beads eonneeted by short refractive isthmuses (figs. 5, 19, 37). The segments may occasionally break apart at the septal giving rise thus to a number of free cells within the host. The zoosporangia are developed direetly from the segments of the thallus. In the early stages they usually possess sereral small vacuoles. but these generally fuse to form a large eentral one as the exit tubes develop. In addition, the protoplasm includes a large number of conspienous refraetive granules, which apparently break up into smaller and smaller fragments as sporogenesis approaehes, with the result that the protoplasm loses some of its refraetive appearanee and beeomes more greyish-granular.

There is eonsiderable disagreement among students of this genus as to where the zoospores are delimited. Many of the early investigators deseribed the protoplasm as emerging through the exit tube and forning an extramatrical vesiele as in Pythium, whieh then underwent eleavage into swarmspore initials (figs, 10-17). With further development and maturity these become aetively motile in the vesiele and are freed eventually by the rupture or deliqueseenee of the resicular membrane. The more reeent workers, lowever, maintained that zoospore rudiments are first delinited in the sporanginm, pass out singly in suecession, and complete their development at the mouth of the exit tube. That they may even be completely formed in the sporangium is supported by the faet that zoospores may frequently be seen swarming inside. Aeeording to these latter investigators a vesienlar memlrane is visible only during the initial stages of zoospore emission (figs. 28 , $4.45)$. The process of sporogenesis doubtless varies to some degree in the different speeies, hut it is probable that the early workers were somewhat in-

\section{PLATE 21}

$$
\begin{gathered}
\text { Myzocytium proliferum } \\
\text { (Figs. 1, 2,5-19 after Zopf, '84) }
\end{gathered}
$$

Figs. 1, . Laterally biflagellate heterocont zoospores.

Figs. 3, 4. Infection stages.

Fig. 5. Young thalli in Spirogyra cell; A, unicellular, $\mathrm{B}$, bicellular, and $\mathrm{C}$, four-celled thallus.

Figs. 6-9. Successive developmental stages of a tricellular thathus; fusiform antheridium in center, sporangium on right, and oogonium on left.

Figs. 10-15. Emergence of protop]asm from sporangrinm, and stages in cleavage and maturation of zoospores within a resicle.

Fig. 16. A six-celled thallus, all segments of which developed into sporangia.

Fig. 17. Recluced Olpidium-like thallus with zoospores in a vesicle.

Fig. 18. Reduced thallus consisting of an antheridium, oogonium, and oospore.

Fig. 19. Elongate thalhus with oospores.

$$
\text { M. zermicolum }
$$

(Figs. 20-24, $27-35$ after Dangeard, '06; figs. 25,26 after Zojtet, '84.)

Fig. 20. Laterally biflagellate heterocont zoospores. Figs. 21, D2. Early germination stages.

Fig. 23. Elongate irregular germination zoospore on nematode.

Fig. 2.4. Infeetion.

Fig. 25. Unicelhular thallus from nematode.

Fig. 26. Nematode with at six-celled thallus.

Fig. $2 \gamma$. Nuclear distriloution in a sporangium.

Fig. 28. Emergence of zoospores.

Fig. 29. Germination in situ. 
l'I.A'Tl: 21

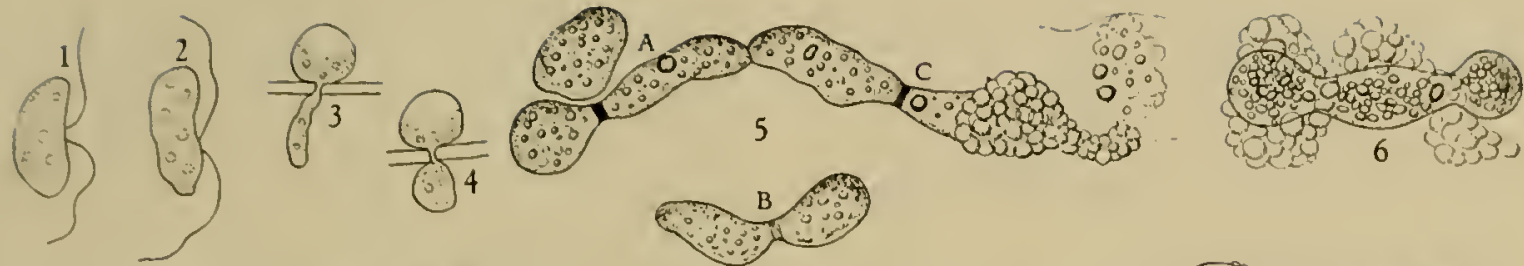

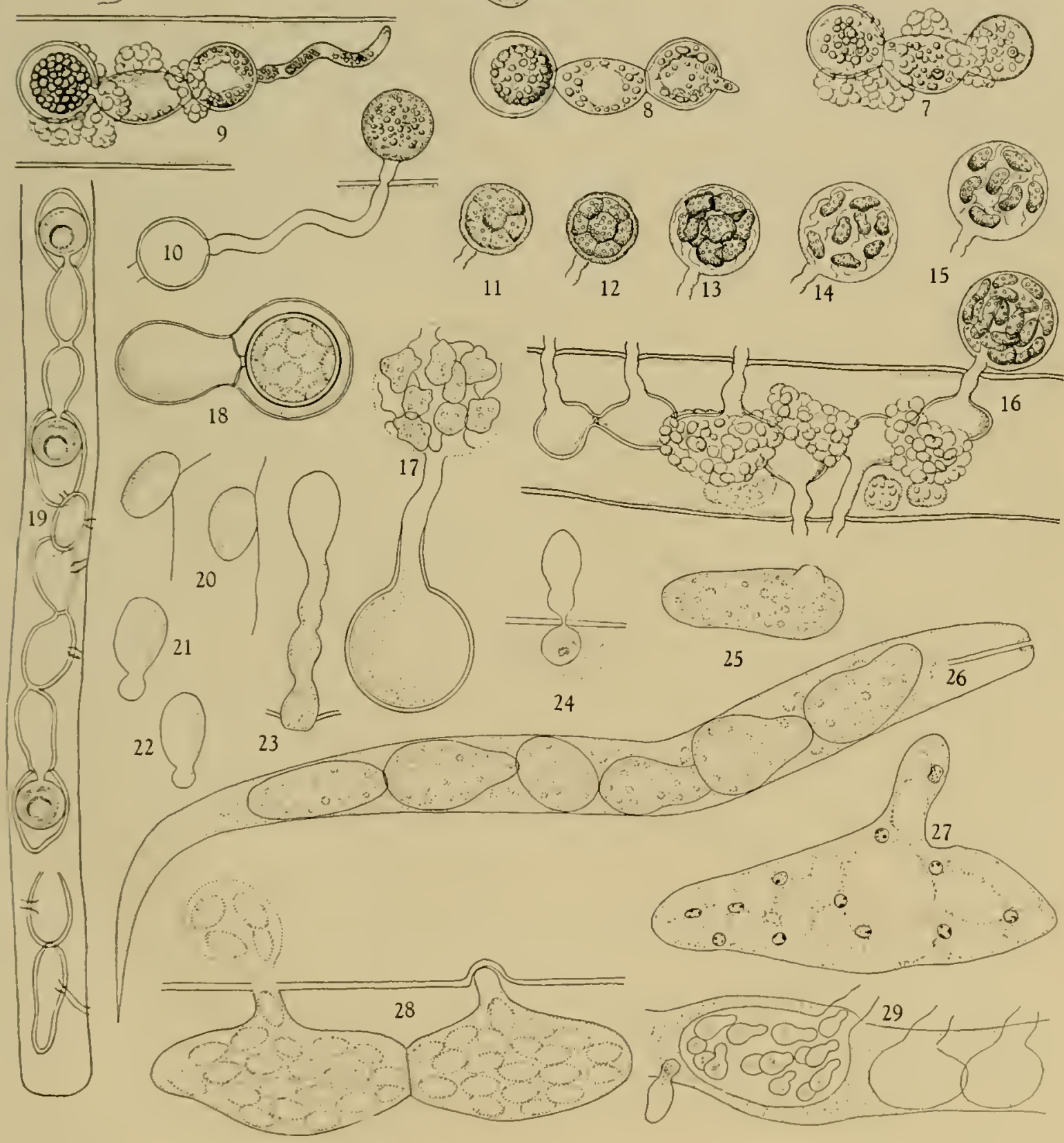

Myocytium 
accurate in their observations. Although Dangeard made a cytological study of the sporangia of $M$. vermicolum, he did not observe cleavage and maturation of the zoospores.

There is also some disagreement about the relative lengths of the flagella in this genus. Dangeard described the zoospores as lieterocont in $M$. vermicolum, with the shorter cilium extending forward (fig. 20). None of the other investigators were very definite on this point, and it is impossible to determine with certainty from their drawings whether the zoospores are iso- or lieterocont. In figure $\mathbf{4 7}$, for instance, Sparrow shows one flagellum to be slightly shorter, while in figure 48 they are more nearly equal in length.

The antheridia and oogonia may occur in the same thallus with the sporangia, but they usually do not appear in abundance until fairly late in the season. They are lut modified segments of the thallus in the same sense as the sporangia and do not undergo any marked differentiation. The so-called antheridium is usually more elongate and cylindrical than the oogonium, but it is not so specialized a structure as in Lagenidium. According to Dangeard, the oogonium contains approximately eight molei, and no differentiation of an egg cell nor the formation of epiplasm occurs hefore fusion. In preparation for plasmogamy seven of the nuclei degenerate, leaving the oogonimu uninucleate. Shortly before or at the time of fusion the protoplasm in the oogonium in $M$. proliferum contracts markedly (figs. 8,9 ) around the tip of the conjugation canal according to Zopf. The antheridimm, on the other hand, is hinucleate (fig. 30), but only one nucleus functions in karyogamy. Prior to fusion a pore is formed in the wall between the two gametangia, or the antheridium sends forth a short tulue into the ongonium (figs. 8, $9,19,37)$. The cytoplasm and one nucleus of tbe antheridium passes into the oogonium, and the two protoplasts fuse. The binucleate zygote begins to contract (fig. 31), and as the oospore wall hegins to form karyogamy oceurs (fig. 32). Dangeard's drawings and description are not very clear and convineing in relation to the critical stages of fusion, and further study of the behavior of the ganctic nuclei is very essential. When an antheridinm lies hetween two oogonia it is capable of fertilizing both, according to Dangeard.

After a period of rest the zygote nucleus divides and the oospore becones multinucleate (fig. 34). Dangeard did not olserve nuclear division, and nothing is known about when and where meiosis occurs. It presumally takes place during the first division of the oospore nucleus. Eventually the oospore devclops an cxit tube (fig. 35 ), but the formation of zoospores and their emergence have not been observed.

M. PROLIFERUM Sehenk, l.c.

Pythium proliferum Schenk, 1859. (Not P. proliferum de Bary, 1860. Jahrb. Wiss. Bot. 2: 182.) Verh. Med. Gesell. Wurzburg 9: 27. Pl. 1, figs. 30-42, 47.

P. globosum Schenk, l.e., 13. 27. Pl. 1, figs, 43-46.
P. globosum Walz, 1870 (pro parte) Bot. Zeit. 28: 556. Pl. 9, figs. 13-19.

Lagenidium globosum Lindstedt, 1872. Synopsis d. Saproleg., p. 54.

M. globosum (Schenk) Cornu, 187?. Ann. Sci. Nat. 5th ser. 15: 21.

Bicricium transzersum Sorokin, 1883. Arch. Bot. Nord. France 2: 43. Fig. 46. 1889. Rev. Aycol. 11: 138. Pl. 78, fig. 76.

Bicririum maso Sorokin, 1883, p. 43, fig. 47; 1889, p. 138. Pl. 81, fig. 117.

Thallus usually elongate, unbranched and constricted; consisting of 1 to 20, usually less than 10 , segments in a linear series. Sporangia byaline, smooth, splerical, 8-25 $\mu$, ellipsoidal, 13-i6 $\mu \times$ I $6-26 \mu$, and elongate witl a single, $2-6 \mu \times 4-48 \mu$, exit tube which may project for varying distances bevond the surface of the liost cell. Zoospores beanshaped, $3.6 \times 5.4 \mu$; partially formed in the sporangium, emerging and developing further in an extramatrical vesicle, freed by the rupture or deliquescence of the latter. Gametangia occurring

PLATE 22

M. zermicolum

(All figures after Dangeard, 06 )

Fig. 30. Two binucleate antheridia and two terminal multinucleate ongonia.

Fig. 31. Incipient oospore with gametic nuclei.

Fig. 32. Completion of karyogany.

Fig. 33. Oospore in median section.

Fig. 34. Oospore witl divided nuclei.

Fig. 35. Early germination stage.

\section{1. megastomum}

Fig. 36. Reduced thallus with elongate exit tubes. Wildeman, "96.

Fig. 37. Portion of thallus slowing sporangia, ongonia, antheridia, and plasmogamy.

Fig. 38. Ancylistes miurii Skrortzow which possibly relates to M. megustomum Skvortzow. Skvortzow, '25.

Figs. 39, 40. Antheridia, oogonia (?) and oosjores of A. minrii Skvortzow, l.c.

$$
\text { 11. zooplithorum Sparrow, "36 }
$$

Fig. 41. Infection stages.

Fig. 42. Young elongate thallus.

Fig. 43. Infected rotifer with numerous thalli, antheridia, oogonia, and oospores.

Figs. 44, 45. Stages in the emergence of the protoplasm from sporangium.

Fig. 46. Cleavage of initial glubule of protojlasm into zoospores; additional fully formed zoospores emerging from neck of sporangium.

Figs. 47, 48. Dorsal and ventral view of zoospores.

Fig. 49. Thallus of 1 . irregulare from Microasterias cell. Petersen, '10.

Fig. 50. Young antheridium and oogonium of $M y z o c y-$ tium (Rhisomyxa hypogra pro part) sp. (?) Borzi, '84.

Fig. 51. Oogonia with oospores, Myzocytium sp. (?) Borzi, ].c.

Fig. 52. Myzocytium sp. (?) from tobacco root cell. Preissecker, 05 . 
PLATE 22

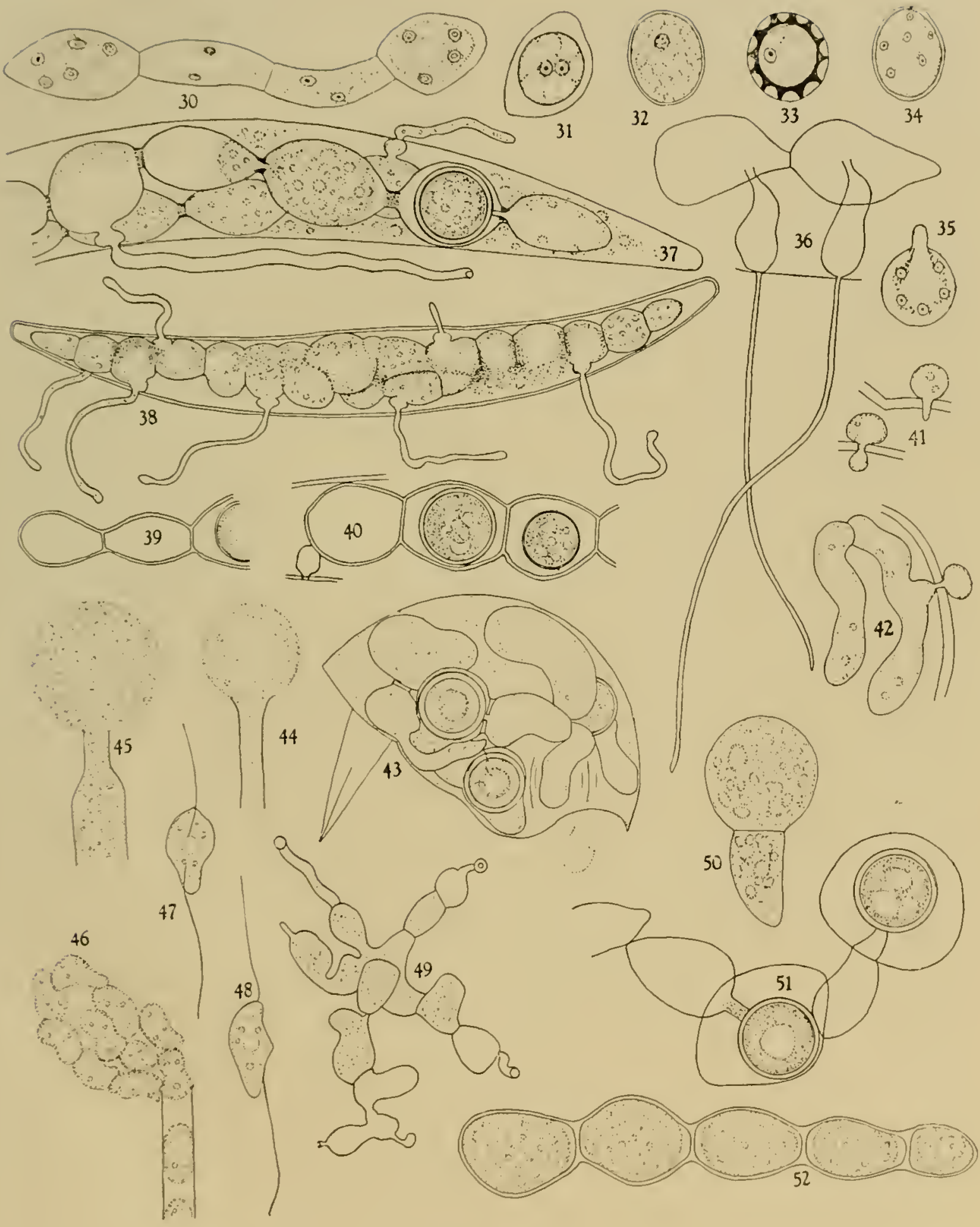

Myocytium 
among the zoosporangia; oogonia spherieal, 15$25 \mu$, oval, ellipsoidal and egg-shaped; antheridia fusiform, and elongate, $8-12 \mu \times 16 \times 18 \mu$, and narrowly spindle-shaped. Oospores spherical, 8$25 \mu$, ellipsoid, $14-22 \mu$, and somewhat angular, hyaline with a smooth thick, two-layered wall and a large eccentric refractive globule; germination unknown.

Parasitic in Mougeotia sp., Mesocarpus sp., and M. pleurocarpus, Spirogyra sp., Zygnema sp., Cosmarium connatum, C. botrytis, Micrasterias rotata, and Closterium didymotocum in Germany (Schenk, l.c.; Lindstedt, 1.e.; Reinsch, '78; Zopf, '84 ; Schroeter, '86; Minden. 'l1); various algae in France (Cornu, '69); Cladophora sp. and Arthrodesmus sp. in Russia (Sorokin. '83.'89); Spirogyra sp., Zygnema sp., and Cosmarium sp. in Belgium (de Wildeman, '93, '95, '96); Cladophora sp. and Spirogyra sp. in Roumania (Constantineau, '01) ; Mougeotia sp. and a dead insect in Denmark (Petersen, '09, '10; Lind, '13); Spirogyra sp. in China (Skrortzow, '27), Cladophora sp., C. luetzingiana, Zygnema cruciatum, Mongeotia sp.. Closterium acerosum and Spirogyra sp. in lowa, Montana, and New York, U. S. A. (Martin, '27; Graff, '28; Sparrow, '32, '33; Thompson, '31); Spirogyra sp. in Bulgaria (Valkanov, '31); S. affinis in lndia (Chaudhuri, ' 31 ; Mundkur, '38): Spirogyra jurgensii, Spirogyra sp., and Cladophora sp. in Japan (Tokunaga, 3 k); Spirogyra sp. and Mougeotia sp. in Hungary (Scherffel, '02; Domjan, '35) ; Spirogyra sp., Mougeotia sp., Zygnema sp., Mesocarpus sp., Closterium leibleinii, and Closterium sp. in Bohemia (Ce.jp, '32, '35).

This is the most widely distributed species of Myzocytium, but although it has been observed and described a great number of times. there are still numerous differences of opinion in the literature about eertain of its developmental phases. Cornu. Walz, Zopf, Sparrow ('32) and Thompson elaimed that the sporeplasm emerges through the exit tube and then undergoes cleavage into zoospores within a vesicle as in Pythium, while other investigators lave maintained that the swarmspores are delimited to some degree in the sporangium. emerge singly in succession. and then complete their development in the extramatrieal vesicle. Sparrow described the zoospores as only $3.6 \times 5.4 \mu$ in size, but Constantinean claimed that they vary from $5 \times 6$ to $6 \times 9 \mu$. This difference may be due to unequal and alnormal cleavage, wherely large zoospores are formed, als has heen described by Thompson. The writer has often found ahnormally large zoospores with four to twelve flagella.

1) warf thalli consisting of one or two segments often occur in this species, and for this reason the author is inclined to agree with Fiseher ('32), de Wildeman ('96), and Minden that Sorokin's Bicricium transversum and $B$. naso may possibly relate to this speeies. Petersen, however, was doubtful about the latter species' identity. It is to be noted here that the exit tubes of $B$. naso are inflated and globular at the hase and extend far beyond the sur- face of the host eell. If this character proves to be of specific diagnostic value $B$. naso, on the other hand, may possibly represent dwarf thalli of $M$. megastomum. Sorokin's Olpidium tuba and O. saccatum nay also possibly be redueed specimens of $M$. proliferum. Cornu ('77) was of the opinion that the parasites which Reinseh (pl. 17, figs. 6-12) found in various desnids relate to this species also, but Zopf ('8t) believed that the one with parthenogenetic oospores figured in Closterium didymotocum is not identical but only elosely related to $M$. proliferum.

Myzocytium irregulare Petersen ('09, '10) which parasitizes Micrasterias and Cosmarium may possibly be nothing more than dwarf and irregular thalli of $M$. proliferum. This species is characterized primarily by irregular and lobed sporangia, the short exit tubes of which are greatly inflated inside of the host wall (fig. 49). Nothing is known ahout the structure and shape of the zoospores, gametangia and oospores. Petersen believed that all forms which had been previously described in flat and small desmids, exelusive of those in Closterium, relate to $M$. irregulare, and that of $\boldsymbol{M}$. proliferum should include only the regular elongate and chain-like forms which occur in the filamentous algae and elongate desmids. He was further of the opinion that $\boldsymbol{M}$. irregulare may also possibly relate to Lagenidium or represent a new genus. Chaudhuri supported the latter viewpoint, but Cejp ('33, '35), who found $M$. irrcgulare in Micrasterias rotata, M, truncata, Cosmarium sp., and Pleurotaenium sp. in Bohemia, thought it may relate to Myzocytium. So far sexual reproduction and oospores have not heen observed. Until more is known ahout the life listory of this parasite and extensive inoculation experiments have been made, the validity of Petersen's species remains doubtful.

Myzocytium lineare Cornu ('72, p. 21) is imperfectly known and very doubtful, and Minden was of the opinion that it relates to a species of Lagenidium. Cornu described it very briefly as simple and sparingly branehed with elongate, linear sporangia, but he did not figure it. He ('77) also belicred that the thalli shown in Reinsch's (l.c.) figures 5 and 14 , plate 17 , relate to $M$. lineare. The data relative to Coruu's fungus are too fragmentary to warrant any definite conclusions, so that the ralidity, identity, and synonomy of this form are largely a matter of personal interpretation.

M. VERMICOLUM (Zopf) Fischer, 189?. Rabenh. Kryptog'fl. 1. 4:75.

M. proliferum var. vermicolum Zopf, 1884. Nova Acta Ksl. Leop.-Carol. Deut. Akad. Nat. 47: 167. P'I. 14, figs. $35-37$.

Biericium lethale Sorokin, 1883. Arch. Bot. Nord France 2: 37. Fig. 45. 1889. Rev. Mycol. 11: 138. Pl. 78, figs. $79-74$.

Zoosporangia spherical, oral, ellipsoidal, irregular, lobed; occurring singly and isolated, in pairs, or up to 12 in a linear chain, with $1-2$ wide exit tubes of variable length. Zoospores oval, heterocont (?). 
short thacellum direeted forward and the long onc backward; delimited in an extramatrical resicte (?) or formed within the sporangimm and eseilping vingly in suce'ssion: germination in siln fairly (oommon. forming a yoast-like hud in gemonation. Ciametangia occurringr anongr the zoopporangia; oogonia oval, cong-shaped and ellipsoidal: antheridin chonsate, cylindrical and slightly spindle-shaped. Oospores splerical and cllipsoidal with a thin endospore and a stellate or polygonally-sculptured exospore: germinating ly beeming transformed directly into a zoosporangium with an exit tube.

l'arasitic in nematodes in Germany (Zopf. l.c.). Russia (Sorokiu, l.c.). France (I)angard, O6), and Bulsiaria (Valkanow, 31).

Aceording to Dangeard, this species is very abundant in linance as a parasite of nematodes, oceurs frequently in association with P'rotascus subuliforms, and mia casily be mistaken for the latter specien when the thalli are young and reduced in size. So far as the author is aware there are no measurements of the thallus, oogonia, antheridia and zoospores of this species to be found in the literiture. Zope listed $M$. zermicolum as a variety of $M$. proliferum, but lischer raised the former to specific rank on the grounds that it parasitizes an entirely different grou]) of organisms. No cross inoculations, however, liave beon masle to determine whether or not $M$. iermieolum will parasitize algae.

Zopf reported that the zoosjores are delimited in an extramatrical vesicle at the tip of the exit tube. while Dangeard deseribed them as heing fully formed within the sporangium. Aecording to the latter worker a few of the swarmspores emerge in a small vesicle (fig. 28 ) which soon hursts and sets them free, while the remaining ones energe singly and in succession. It is to be noted liere that zoospore (mission in $M y z o c y t i u m$ sp).. deseribed by Thompson ('3.t) in Spirogyra sp.. is very similar to that reported hy Dangeard. With the exception that no small vesicle oceurs around the initial emerging spores. Further study is accordingly necessary to determine which or it both of the reported methods of zoospore formation and cmission occur. It is partieularly notewortly that Dangeard figured the zoospores as heterocont with the short cilium directed forward and the longer one backward (fig. 20). as in the casc of secondary swarmers of Lagenidium species; whercas in otler species of Myzocytium they are figured as isocont. In this respect also further study of this species is very ensential.

Maupas' ('15) M. polymorphum, the thallus of which breaks "l, into free and independent sporangia at maturit $x$ probably relates to this species. He merely autentincel it in relation to I'rolasens and apparently has wever figured or described it further.

M. MEGASTOMUM W'ildeman, 1893. Аnn. Sm. Helge Micro. 17: ;3. 1'1. 6, figs. 6-10; pl. 7. figs. 19-20.

Anrylistes miurii skvortzow, 192.;. Arrh. l'rotislk. is1: 432. Fizs. i-10.

'Mhallus at first "ylindrical. $7.1-12 \mu$ thick. unhrancled; later becouning constricted and septate, consisting of 5-18 ovoid, ellipsoid, elongate atnd somewhat cylindrical, $9-26 \mu \times 12-50 \mu$, segments with a single exit tube which is inflated, ghobular 3.7 t.2 $\mu$ in diameter. irregularly lageniform ind ilppressorial-like inside of host wall, and mily extend to a distance of $150 \mu$ on the outside of host. size, structure and hehavior of zoospures unknown. Antheridia oval and spindle-shaped; oogonia ovil, harrel-shipued, 12-15.5 $\mu \times 7.4-12 \mu$; oospores splecical, $7.1-1: 3 \mu$, with a thick, lyyaline, smootl wall and several refractive globules; germination unkuowu.

'Parasitic in Closterium attenuatum and Spirotaenia s]3. in Belgium (de Wildeman, '93, '95, '96); ('losterium sp. in Manchuria (Skvortzow, 1.c.); Closterium sp. and Menrotanenm trabecula in Bohemia (Cejp, '35) : C. striolatum and ('. aroolatum in North Carolina, U. S. A. (Berdan, '38).

Whether or not $M$. megastommm (de Wildeman) forma Skvortzow (1.6.. p. 4.31), which oc('urs in ('losterinm sp). is a variety or form of de Wildeman's species is uncertain, but the writer is at present of the opinion that it is identical with the latter. It is characterized by glohular and spherical, 12.9$22.5 \mu$, sporangia, $10-23.5 \mu$ long exit tuhes, and splicrieal, $11-13 \mu$, smooth, hyaline onspores.

Incylistes miurii Skvortzow is possibly identiea] to de Wildeman's species also. The author is accordingly listing it as a syonym and presenting figures of its thallus and resting spores (figs. 38-10). As Miss Berdan has pointed out, the infection hyphae whieh Skvortzow fignred may he nothing more than exit tulses for the emission of the zoospores. Unti] the presence of conidia and direct infection by hypliae have been demonstrated, Skrortzow's sperie's will remain a doubtful species of either Incylistes or $\boldsymbol{M}_{y}$ ocytium.

M. ZOOPHTHORUM Sparrow, 1936. Jour. Linn. Soc. London, Bot. 50: 1.61. Pl. 19, figs. 1-14.

Thallus rarcly hranclicd, constricted or unconstricted, septations narrow and inconspieuous, secrments 5-17 $\mu$ in diameter, variable in length. Zoosporangia irregular, sac-like and lohed with a single short exit tube. Zoospores $6-7 \mu \times 10-11 \mu$; partially or wholly delimited within the sporangium, emerging in succession, and forming a subspherical mass at the mouth of the exit tube, whiels soon scparites into irregular segments. Sexual fusion tlirough a pore; oospores hyaline, smooth, thick-walled, splerical. I $2-15 \mu$, with a large refractive globule; germination unknown.

l'arasitie in rotifors and rotifer egers in kingland and I)enmark.

Sparrow was uncertain about the gencric position of this species. In som respects it rescubles reduced thalli of $M$. zermicolum, while in other instances the tubular. contorted se rments are rominiscent of $L$. pygmaeum. In sexual reproduction, how evre, it is like. Myzocytium. More recently ('39) Sparrow has pointed out its similarity to $L$. aphilnm which also piarasitizes rotifer cegrs. "I'le possi- 
bility that it is not identical to the latter species thus remains to be shown.

Sparrow ('36, p. 163 , fig. 4q) further deseribed an elongate thallus consisting of a linear series of elliptical segments, $20-22 \mu \times 18-20 \mu$, connected by narrow eylindrical, refractive isthmuses in $S y n e-$ dra sp., which lic believed may likewise relate to Myzocytium. He did not. however, olserve any developmental and reproductive stages.

In connection with the ahove report of doubtful Myzocytium species it may be pointed out that Stein ('51, pl. 18, tigs. 1-7: '59. pl. 1 , figs. 49-55) figured an elongate body in Iorticella microsoma which he believed relates to the developmental cycle of this animal. At maturity this thallus becomes contorted and lohed and gives rise to bean-shaped spores in a spherical, extramatrical vesicle. The structure and appearance of the sporangia and spores suggest very strongly that they may relate to a species of $M y z 0^{-}$ cytium. He ( 59, pl. i, fig. 9) also showed another vesicle with spores in $I$. nebulifera which may also possibly belong to a similar parasite.

Preissecker ( 05, p. 3, fig. 43 ) figured and bricfly described a linear series of oval pale golden cclls in the roots of tobacco which he believed might represent a dwarf individual of Myzocytium sp., the largest cell of which measures $28 \times 37 \mu$ (fig. 52). Zoospores and oospores were not observed. As Preissecker pointed out, the extremely thick walls of the cells militate against the possibility that this is a species of Myzocytium.

It is not improbable that the heterogamous sexual stages which Borzi (' 84 ) included in the life cycle of Rhisomy a hypogea may relate to a root inbahiting species of Mysocytium. This is the viewpoint expressed by Schraeter ('97) and Minden ('11). More recently Barrett ('35) found similar sexual stages in association with a plasmodiophoraceous species in roots of Stellaria media and likewise concluded that they relate to a species of Lagenidiaceac. In view of these observations two of Borzi's figures have been included in plate 22 of Myzocytium.

Whether or not the fungus figured by Turner ('92) in Oedogonium sp. relates to Myzocytium or to the Lagenidiaceae is very doubtful. Superficially, it bears some resemblance to the thallus of $M y z o c y-$ fium, but the presence of several connecting isthmuses between adjacent segments militates against its inclusion in this genus.

\section{LAGENA}

Vanterpool and Ledingham, 1930. Canad. Jour. Res. 2 : $17 \%$.

(PLATE 23)

Thalli intramatrical, unicellular, coenocytic, solitary or numerous, sac-shaped, oval, elongate, tubular, lobed and branched; attached to the host cell wall by a short neck the end of which fits into a thickened collar: transformed holocarpically into zoosporangia or gametangia at maturity. Zoosporangia hyaline, smooth, and of the same shape as the thallus; content emerging at maturity through a short exit tube into an extramatrical vesicle and cleaving into zoospores. Zoospores bean-shaped, isocont, flagella inserted in a lateral depression. Male and female thalli fairly equal in size and usually indistinguishable, hyaline, smooth, oval or slightly elongate; conjugation canal of variable length, developed by the male thallus; no differentiation of an egg cell and periplasm; multiple fertilization rare. Oospores single or rarely numerous, hyaline, smooth. oval, spherical, thick-walled, simple or compound with one or two large refractive globules; germination unknown.

This monotypic genus has many characteristics in common with Lagenidium, Myzocytium, and $P y-$ thium. The isocont bean-shaped zoospores (fig. 8) have two laterally inserted flagella and the same characteristic method of swimming as in these genera, but sexual reproduction is predominantly isogamons. In germination the zoospores form an infection tule which penetrates the host cell wall (fig. 1 ), and after it has grown into the host cell its tip begins to enlarge and eventually develops into the mature thallus. The extramatrical zoospore case gradually disappears in the meantime, but the intramatrical portion of the germ tnlse remains attached to the thallus as a neck in contact with the host wall. A thick collar is formed around its upper end by the host cell wall at maturity, which gives it a characteristic appearance when viewed from above (figs. 2, 11-16).

The mature thalli may he comparatively small, oval and oblong as in Olpidium (figs. 1, 2) or greatly elongate, curved, lobed, hranched, and hypha-like (fig. 3), as in Lagenidium. A single thallus may completely fill a host cell, or several small ones may be present in one cell. They may develop directly into

\section{PLATE 23}

Lagena ruticicola

(Figs. 3, 17, and 18 drawn from photographs after Truscott; other figures after Vanterpool and Ledingham.)

Fig. 1. Stages of infection and development of the thallius.

Fig. 2. Two mature thalli and an empty sporangium.

Fig. 3. An elongate, tubular branched thallus.

Fig. 4. Mature sporangium with elongate exit tube.

Figs. 5-7. Stages of the emergence of the protoplasm into a vesicle and cleavage into zoospores.

Fig. 8. Rujture of vesicle and liberation of the zoospore. Fig. 9. Encysted zoospore.

Fig. 10. Empty sporangium and an encysted zoospore on surface of host cell.

Figs. 11-15. Stages in oospore development; content of male thallus passing into female thallus.

Fig. 16. A free mature oospore.

Fig. 17. Multiple fusion: contents of three male thalli passing into one female thallus.

Fig. 18. Compound oospore. 
PLATE: $2: 3$
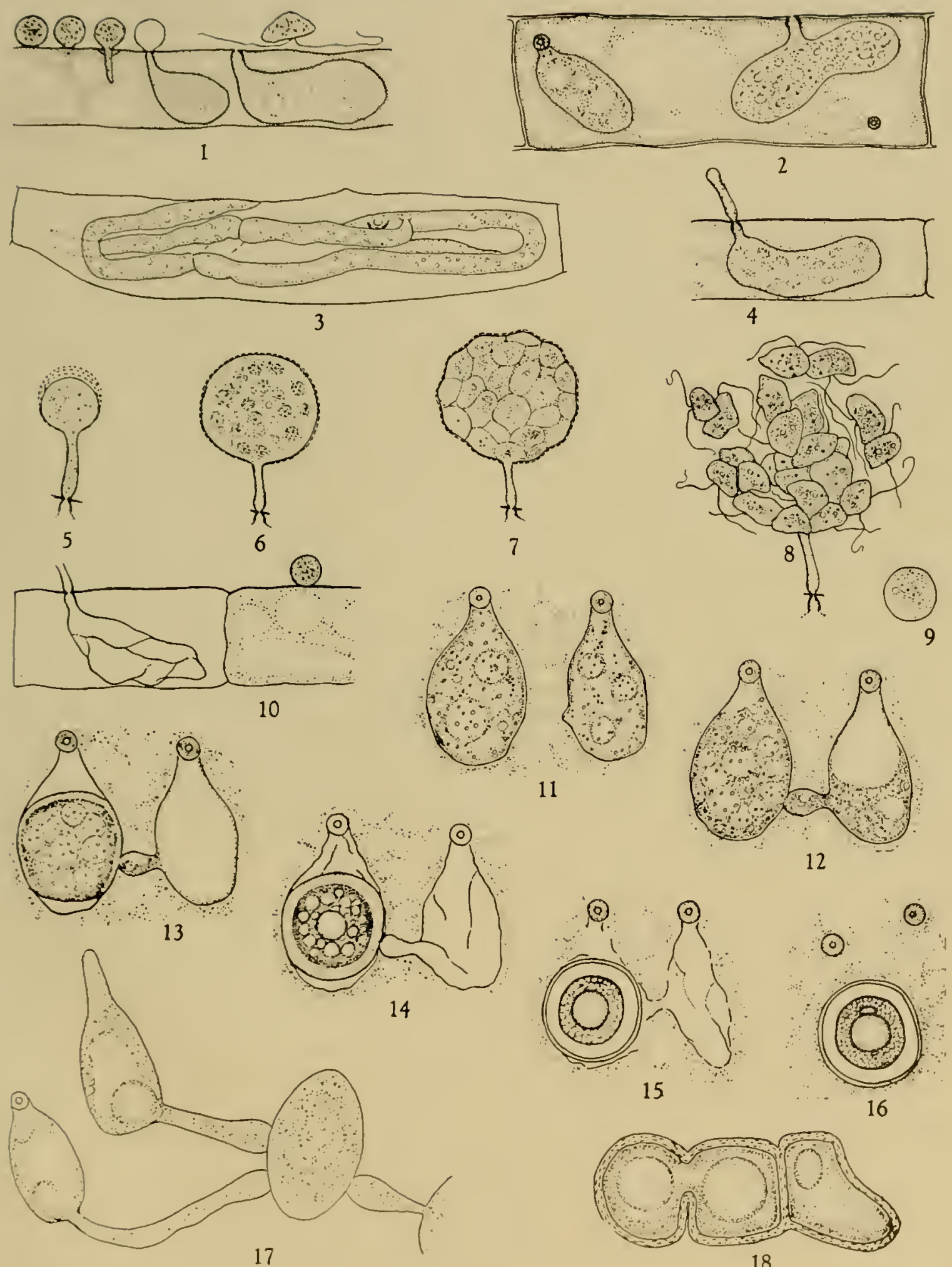

Lagena 
zoosporangia or male and female gametangia. In the former ease a short exit tuhe grows out from the neek of the thallus (fig. 4 ), and as the protoplasm begins to move out its tip gradually enlarges into a spherical vesicle into which the entirc contents of the thallus emerges (figs. 5-6). Vanterpool and Ledingham regarded this vesicle as the sporangium proper and referred to the thallus whieh gives rise to it as a presporanginm. The emerged mass of protoplasm soon hegins to cleave progressively into segments (fig. 7), and the whole mass of zoospores shows the same morement and behavior as in $P y^{-}$ thium.

Sexual fusion may occur between two or more thalli in the same cell. One of these, which is designated as the male, puts ont a conjugation tube of variable length which fuses with a female thallus (figs. 12. 13, 17). If the two are almost in contact the tube may he reduced to a small swelling on the side of the male thallus at the point of contact with the female. The content of the male then passes very slowly into the female thallus (figs. 12, 13), where the eombined protoplasts eventually contract and assume an oval or spherical shape (fig. 16). No delimitation or differentiation of an egg cell and periplasm occurs in the female thallus in preparation for fertilization, according to Vanterpool and Ledingham, hut Truscott's ('33) report that several oospores may be formed in one female thallus suggests at least that division of the ooplasm may take place. On the other hand, division may possibly occur after fusion has heen completed. A thick wall is eventually formed around the zygote, and after a short while the empty remains of the male and female thalli disintegrate, leaving the oospores free (fig. 16). Occasionally two or more male thalli may fuse with one female (fig. 17). The conjugants are multinucleate, according to Vanterpool and Ledingham, but nothing is known ahout the behavior of the gametic nuclei before and during fusion.

The formation of oospores may be increascd by drying out the soil slightly, and Vanterpool and Ledingham therefore coneluded that sex is largely determined by adverse environmental conditions. They described Lagena as dioecious but were uncertain whether the zoospores which give rise to male and female thalli respectively come from the same or different zoosporangia. 'They nonetheless assumed that zoospores from sporangia and germinated oospores may be of three types: i.e., + and ,-- and + , as shown in the diagram below.

Vanterpool and I.edingliam emphasized the striking similarity of Lagena to reduced species of $P y$ thim $m$ and Lagenidium and regarded it as a possible connecting link hetween the Lagenidiaeeae and $\mathrm{Py}$ thiaceae.

L. RADICICOLA Yanterpool and Ledingham, l.c. Pls. 1, 2. Figs. 3-7. 'Truscott, 1933. Mycologia 25: 263. Figs. 1-ll.

Thalli $1.4 \times 35 \mu$ or more, exit tubes $4 \times 10-$ $20 \mu$; zoospores $7 \times 11 \mu$; oospores $10-25 \mu$. (For additional details see generie description above.)

Parasitic in roots of Triticum aestivum, T. durum, Hordeum vulgare, Secale cereale, Agropyron repens, Zea mays, and other wild grasses in Ontario and Saskatchewan, Canada.

Aecording to Truscott, this species may oecur on a number of wild grasses, but Vanterpool and Ledingliam found it to be more limited in host range. Avena satiza, A factua, Agropyron Tenerum, A. spicatum, Bromus inermis, Poa compressa, and Sinapsis arvensis remained inmune to attack when grown among infected wheat plants. Lagena radicicola causes a root disease which is eharaeterized by stunted, curved roots. The fungus has a predilection for cells in the root tip, and its interference with nuclear and cell division doubtless leads to the shortening and curvature of the roots. Infected roots have yellowish-brown lesions in the region of infection and the root svstem as a whole is redueed. No enlargement of cells nor hypertroplyy of roots have been ohserved. The stems of infected plants are considerably shorter than those of normal specimens, while the leares become pale-green and lighter in color.

The thalli descrihed by Truscott from Toronto were more elongate, cylindrical, tnbular, and brauched than those found hy Vanterpool and Iedingham in Saskatchewan, and it is thus evident that the thallus of $L$. radicicola may vary markedly in size and shape. Truscott reported and figured compound oospores (fig. 18) and found evidence that as many as six oospores may possibly be formed in one female thallus.

\section{DOUB'TFUL GENERA RESTICULARIA}

\author{
Dangeard, 1891. Le Bot. 2: 96.
}

(PLATE 2.)

Thallus intra- and extramatrical, broadly elongate, tubular, vesicular and filamentous; irregular and undulating in contour, constricted at irregular intervals, with numerons short protuberances and

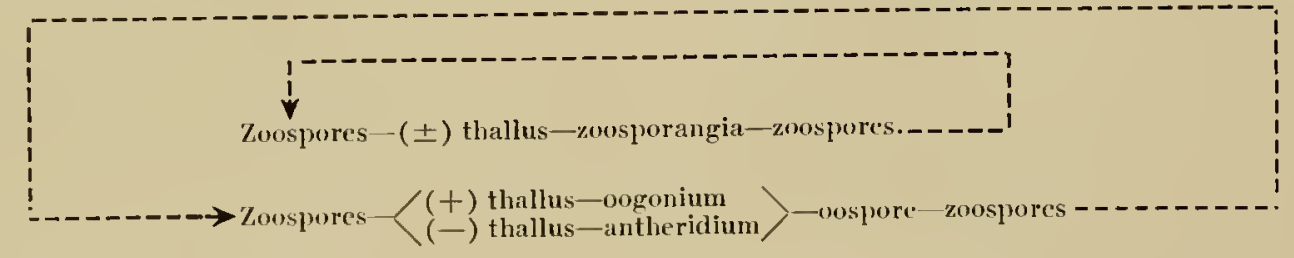


hranclues, eontined to a single lost filament or becoming extramatrical and infecting screral algal thronds. Zoonporaneria not sharply differentiated (?). contents emerering as a mass ind undergoing cleavage as in l'ythimm (:). Zoospores oval, laterally hifagcllate and iscoust. Sicxual reproduction imjerfectly known; two similar-sized protoplasts of adjacent swellings in the same thallus fusing to form splucrical resting spores (ocspores. zygospores? ) : gremination unknown.

This grenus was created hy I)angeard for a filamentous parasite of L,yngliya aes/uarii found in France. Hrolaned liesticularia in the Ialgenidiacene (Ancrelistales) close to Lagenidium and Myzocytium, hut lis description of its development and life eycle was manger and incomplete. As a result the identity and relationslipss of this genus have bean the suliject of much discussion and disagrecment among systematists in mreology who are not particularly fimiliar with the lagenicliaceac. Saccardo ('91, '12) followed Dangeard's disposition of this genus, lut some mycologists (Minden, '11; Fitzpatrick. "30) regarded it as a doubtful member of this group, principally hecause of the olservations of Fritscl ('03). Other mycologists (Fischer, '92; Wildeman, '96; Seluroeter. '97; Fritsch, l.c.) liave placed it next to Ancylistes and looked upon it as related to this geuus or a transition form between the Lagenidiaceae and Ancylistes. The latter views of course antedate the discovery that Ancylistes helongs among the Entomopthorales and does not relate to the Laigenidiaeeae.

Olservations on a parasite found in L.yngbya in the lahoratories at Columbia suggest that the organism found ly Dongeard is a ralid member of this family. This view is further supported by the recent discovery of Couch ('+1) that the zoospores of Reslicularia sl. arc laterally hiflagellate and isocont. However, the question of whether Resticularia slould stand as a distinct genus or be merged with Lagrnidinm or Myzocytium remains to he answered. At present. the author is of the opinion that his fungus and probably. Dangeard's $R$. nodosa relate to sprecies of Lagenidinm. Furtlee studies on the methorl of sexual reproduction are ncessary before this point can lee settled. The autlor is further of the opinion that the fungus which Fritsch descrilsed as $R$. nodosa as well as $R$. Boodlei in suecies of Tolypothrix do not relate to Resticularia in the sense of bangrard. "l'lue'y are accordingly listed as doulst ful or cxeluded specit's. Deserjptions and illustrations of them are uevertlacless included in plate $2+$ to make tluese data available to researcly students.

Accurding to Mangeard, the zoospores are posteriorly unflagellate. lut it is not juprobalsle that lie may have overlookerl a sceond flagellum of the tye slown in figure 1. The large zoospure's come to rest on the algal filament and form a lirmal germ or infection tube which penet rates the loust cells (fig. 22). "Tle tij) of this tube elongates, increases in diameter, and crentually develops into the mature veceretative thallus (figs. - j) while the zoospore c'asc romains on the outside. At maturity the thallus may hramels screral times, grow out levond the lust, and infect

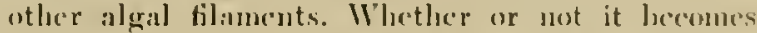
septate is not ohvious from I angerard's reacription. 'l'he muchei are rather evenly distributed along the length of tho thallus (fig. 7,8 ). No sharply differcutiated zoosporangia were tigured hy Dangeari, which suggests that clomgate segments of the thallus function in this capacity as in filancutous species of Lagendium. At any rate the sporeplism energe's througl an texit tulic (fig. 6 ) and undergoes cleasage into zoospores.

Very little is known ahout sexual reproduction, and no well-elefined antheridia and ongonia have yet bec'n described. According to Dangeard, the protoplasm in portions of the thallus contrats into two masses in adjacent swellings (fig. 9) which fuse to form oral. ellipsoidal, and splic rical resting spores (figs. 10, 11). Inasmuch as the protoplasts as well as the swellingrs in which they accumulate are usually equal in size, I)angeard referred to the resting spores as zygospores. The type of spore formation shown in figure 9 is suggestive of scxual reproduction in $M$ yzocytimm, although intervening sejta are lacking. Fischer was of the opinion that if Dangeard"s account of sexual reproduction is correct Resticularia is to be regarded as a forermuner of the Zygomycetes.

R. NODOSA Dangeard, I.c. Pl. 4, figs. 25-31; pl. 5, figs. $3,4$.

Resting sprores usually nume rous, oval, cllipsoidal, clongate and spherical, $6-10 \mu$ in diameter, contents coarsely gramlar with a large refractive globule, wall thick and domble-layered. For additional details see generic diagnosis above.

l'arasitic in Lynybya aestuarii in l'rance, killing the cells and causing the filaments to turn light yellow or eolorless.

Fritsch found a similar looking fungus in Tolypothrix in England whiclu he took to lue the same as 1)ingeard's species. The endophytic mycelium is ('omplaratively coarse, $\$-6 \mu$, irregular. frequently septate, and forms mumerous hrown, oval, spherical and ellipsoidal. 6-9 $\mu$, thick-walled chlamydospores (figs. 12, 1.t), while the cetoplytic nycelium is much finter, 0.5-1 $\mu$. more branched, and bears single chlamylospores on short lateral braneloes (fig. 13) Fitsch believed that the \%ygospores ilescribed by Dingeard are nothing more than chlamplospores. the formation of which does not involve sexusl tusion. While the endophytic mycelimm of Fitsch's lungus resembles the thallus of $K$. nodosa, it possibly loes not relate to l)angrard's species at all since l: ritsch failed to obscrve zoosporangia or zoosjores. Whather the fungus reported hy . Sparrow ('32) iu filanents of Tolypothrir in Massachusetts relates to li. nodosa or l'ritsely s organism is uncrertain becausc neitler zoosporangia and \%ouspores nor sexmal reproduction were oliscrued.

liesticularia boodlo is appurently further remored from I angeard's specoues than the two alume- 
mentioned fungi. The endopbytic mycelium is nevertheless ir regular, $5-8 \mu$, with occasional septa (figs. $16-20$ ) as in the previous species, but the ectophytic mycelium, $1.5-5 \mu$ in diameter, is highly branched, septate, and bears numerous thin-walled conidia (12-15 $\mu$ in diameter) in chains on lateral branches (fig. 15). Zoosporangia, zoospores, resting spores, and chlamydospores are unknown.

Whether or not R. Oedogonii Skrortzow ('25, p. 432, fig. 14) is a valid lagenidiaceous species is uncertain at present. This species parasitizes Oedogonium sp. in North Manchuria and is claracterized by a branched, hyaline, fine, 1-17 $\mu$ thick endophytic and a sparse ectophytic mycelium. The resting spores are hyaline, smooth-walled, 11.5$18.5 \mu$ long by $7.4-11.1 \mu$ wide, and contain a large refractive glolule. Zoosporangia and zoospores have not heen observed.

\section{EXCLUDED GENERA}

\section{ACHLYOGETON}

\section{Schenk, 1859. Bot. Zeit. 1\%: 399.}

Thallus intramatrical, usually elongate and septate, consisting of a chain or linear series of fairly short oral, ellipsoidal, egg- and spindle-shaped segments with truncate cnds; constricted at the septa; rarely dwarfed and unicellular, holocarpic. Sporangia of the same size and shape as the thallus segments or unicellular thalli, with one exit tuhe of variable length which may or may not be inflated before passing through the lost wall, extending a short distance beyond surface of host. Zoospores delimited in the sporanginm; diplanetic, emerging singly in succession, and encysting in a loose cluster at the mouth of the exit tube as in Achlya; emerging from the individual cysts and swimming away; posteriorly uniflagellate (?) with a small refractive glohule. Resting spores (doultful) formed asexually (?) by the contraction and encystment of the cell content; germination unknown.

The development and structure of the regetative thallus are so strikingly similar to Myzocytinm that it is very difficult to avoid a suspecion that Schenk may have heen incorrect about the number, relative lengths and insertion of the flagella on the zoospores. This possibility is further suggested by the fact that he figured the swarmspores of Myzocytinm, Lagenidium, and Pythium as uniflagellate also. Although Martin and 'Tokunaga saw encysted zoospores, they unfortunately did not determine the number of flagella and thus settle this important question. It is to be noted in this connection that the zoospores of Lagenidium Oedogonii also may encyst in il cluster at the mouth of the exit tuhe, which shows that such a character is common to the Lagenidiaceac and is in itself no basis for excluding Achlyogeton from this family. Shonld the zoospores prove to be bean- shaped and laterally biflagellate Achlyogeton might well be merged with Myzocytium provided both genera are also similar in type of sexual reproduction. The presence of posteriorly uniflagellate zoospores with a single ref ractive globule and the lack of antheridia and oogonia at present militate against this view. Achlyogeton is accordingly excluded from the Lagenidiaceae for the time being. It may be noted here that its thallus resembles that of Septolpidium which is likewise characterized by uniflagellate zoospores. The latter, however, do not encyst at the mouth of the exit tuhe as in Achlyogeton but swim away after a brief pause - a characteristic which precludes close relationship with the latter genus, according to Sparrow ('36). Six years later, however, Sparrow ('42) reversed his opinion about this characteristic and included Achlyogeton with Septolpidium and Bicricium in a new family, the Achlyogetonaceae, of the Chytridiales.

\section{A. ENTOPHYTUM Sehenk, 1.c. Pl. 13, figs. A1-8.}

Thallus composed of one to 15 segments. Sporangia oval, broadly ellipsoidal and egg-shaped with truncate ends, $15.6-33.6 \mu \times 9.6-20.4 \mu$; exit tubes $27-60 \mu \times 3.6 \mu$. Primary zoospores elongate as they emerge; cysts spherical, $4 \mu$; secondary swarmers more oval, rounded at the anterior and tapering sliglitly at the posterior end; flagellum approximately three times the length of the spore. Resting spores hyaline, smooth, oval and spherical.

Parasitic in Cladophora sp. in Germany (Schenk, 1.c.); Cladophora sp. and Anguillula sp. in Russia

\section{PLATE 2.1}

(Fig. 1 after Couch, '11; figs. 9-11 after Dangeard, 91; figs. 12-20 after Fritsch, '03.)

Fig. 1. Laterally biflagellate iscocont zoospore of Resticularir sp.; anterior flagellum witl tinsel; posterior flagellun with tail piece.

\section{R. nodosa}

Fig. 2. Germination of zoospore and infection of Lyngbya filament.

Figs. 3, 4. Later developmental stages of thallus.

Fig. 5. Coarse ir regular branched thallus.

Fig. 6. Emerged vesicular mass of protoplasm prior to cleavage; encysted zoospore above.

Fig. 7, 8. Distribution of nuelei in tliallus.

Fig. 9. Plasmogamy of adjacent protoplasts in oospore (zygospore) development.

Figs. 10, 11. Young and mature oospores (zygospores).

Fig. 12. Mycelium with internal chlamyclospore.

Fig. 13. Stages in ehlanydospore formation.

Fig. 14. Mature ehlamydospores.

\section{R. boodtri}

Fig. 15. Extramatrical mycelium with spores.

Fig. 16. Young thallus from germinated spore.

Figs. 17, 18. Intramatrical mycelium.

Fig. 19. Infection of two Tolypothrix filaments.

Fig. 20. Thallus with germinated spore and three infection liyphae. 
PIA'I' 24

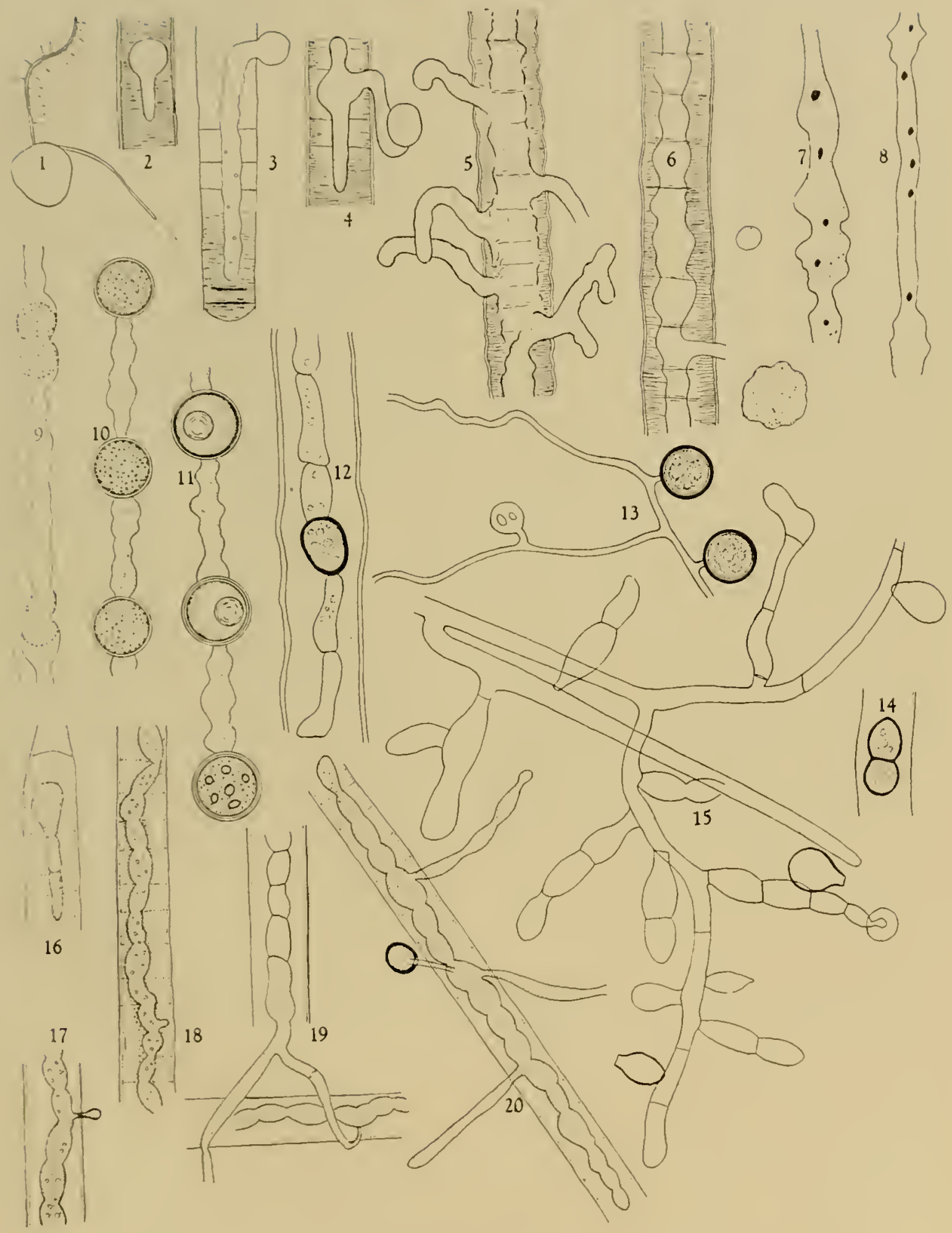

Resticularia 
(Sorokin, '76, '83, '89); Cladophora sp. in Iowa, U. S. A. (Nartin, '27) and Japan ('Tokunaga, '31).

The thalli which Sorokin ('76) figured in Anguillula are somewhat sinilar to those of Mysocytium, and there is accordingly the possibility that he may have confused this species with $M$. vermicolum. Ile is the only one to have reported $A$. entophytum on hosts outside of Cladophora. He nevertheless reported that the zoospores encyst in a cluster at the month of the exit tube in the same manner reported by Schenk, although he did not illustrate them.

Tokunaga found resting spores accompanied by a small, spherical, hyaline companion cell which he believed may relate to a species of Olpidiopsis parasitic in Achlyogeton.

Achlyogeton solatium Cornu ('70), parasitic in Oedogonium obsidionale, is imperfectly known, very doubtful, and has never heen figured. Its thallus is filamentous, branched, and apparently extends through several host cells. The sporangia are delimited at irregular intcrials along the thallus and form a single exit tube which is seven to eight times the diameter of the lost cell in length. Three to twelve zoospores emerge from the sporangia and encyst in a cluster at the mouth of the exit tube, and after a while they cmerge leaving the cysts behind as in Achlya. In addition, Cornu, reported the presence of an extremely irregular, cylindrical oogonium with one to several oospores, but he did not observe the character of the antheridim. Fischer ('92) regarded Cornu's fungus as a speeies of P'ythium, while Minden disregarded it entirely.

Achlyogeton rostratum Sorokin ('76) is a douhtful species. It parasitizes Anguillula and consists of chains of short oval segments or sporangia, 5-6 $\mu \times$ $7-9 \mu$, with one straight, curved, or tortuous exit tube which becones markedly inflated before passing through the host wall (figs. 11, 12). Zoospores and resting spores are unknown. Inasmuch as Sorokin did not observe the zoospores and their behavior, the relation of this species to Achlyogeton is questionalble. The thalli shown in his figures are fundamentally similar to those of Mysocytium and may equally well relate to that genus. The inflation of the exit tube is not a distinctive specitic character since Schenk has shown that it may oceur in A. entopliytum also.

Achlyogeton salinum Dangeard ('32) which parasitizes the marine algae Cladophora laetevirens and C. Havaescens in Irance is likewise too little known to ascertain its identity and ralidity as a member of this genus. Dangeard observed only developing and mature thalli, including sporangia and quiescent zoospores; so that nothing is known about the mumber, relative lengths, and position of the flagella in this species as well as its method of sexual reproduction. The mature thalli (figs. 13, 14) are strikingly similar to those of $A$. entoply $t u m$ which parasitizes a fresh-water species of Cladopliora. On the other haml, they are also similar to the thalli of $M y z o c y-$ tium and may equally well relate to a species of this genus.

\section{PROTASCUS}

Dangeard, 1903. C. R. Acad. Sci. Paris 136:

628. (Not Protascus Wolk, 1913.)

(PLATE 25)

Thalli intramatrical, single or numerous, elongate, cylindrical, unbranched and unconstricted, straight or curved, and septate; segments separating at maturity and with further growth becoming transformed into sporangia and gametangia. Sporangia cylindrical, flask-shaped, uteriform, pyriform, and slightly irregular, usually with a single curved or straight short tapering exit tube which may end almost flush with the surface of the lost cell or extend for a short distance beyond. Spores, non-motile, slightly curved and clavate, forcibly ejected from the sporangia; adhering to the host cell for some time after germination. Gametangia occurring among sporangia, unicellular, holocarpic, unequal in size, formed from the same or different thalli; conjugation usually lateral, sometimes scalariform or end to end; hoth gametangia contributing to the formation of the conjugation canal; contents of the larger female and smaller male gametangia often contracting toward the canal before plasmogamy; no differentiation of an egg cell and periplasm; protoplast of male flowing into the female gametangium and fusing with the ooplasm. Resting spores rarely parthenogenetic, lying free in the female gametangium, spherical and smooth with a fatty granular content which gives it a blackish, opaque appearance; germination unknown.

In ignorance of its method of sexual reproduction Dangeard placed this genus among the Hemiascales because of its non-motile spores and the manner in which they are ejected from the sporangium. At the same time he called attention to the similarity of its thallus to those of $M_{y}$ zocyfium and Lagenidium. In his opinion Protascus may possibly he a transitional genus between the Phyconycetes and higher Ascomycetes. Since the discovery of its phycomycetous type of sexual reproduction by Maupas, however, Dangeard's views are no longer tenable. Maupas called the resting spores, zygospores, but pointed out the similarity of their method of formation to that of the oospores of Myzocytium. He regarded Protascus as a possible member of Fischer's Merolpidiaceae. the direction of growth of which has becone distinctly oriented by its elongate host. Maire, on the other hiand, assigned it to a position between the Lagenidiaceae and what was formerly known as the Ancylistaccae and proposed a new family, Protascaceae, to include it. Fitspatrick regarded the resting spore as an oospore but was doubtful about the relationship of Protascus with the Lagenidiaceae. The lack of zoospores sharply delimits this genus from the lagenidiaceac as the family is now recognized, and it is accordingly excluded. However, inasmuch as it has often been described in relation to Lagenidium, Myzocytium, etc., the author 
feols that the following lorief description is warrauted.

Aerording to l)angeard and Maupas, this parasite may oceur in erreat aloumdance and can be easily enltured in living nematodes for a lomg time. 'l'he spores are predacenus, retain their vitality for a long time. and up to 15 days they are capalile of infecting nematede's with which tley come in coutact. 'The slender end of the spore apparently is adhesive. since it is at this end that it lecomes stuck to the nematode as the latter lurusles against it. In spite of the squirming and withing of the host, the spores remain attached in this position and soon ererminate. Whey send a tine. 0.3-0.t $\mu$, germ tube through the cuticle into the menatode (figs. is, i). and as the eontent of the spore passes into its tip) it swells into a glolular structure. This elongates in a linear direction and lecomes filamentous. The young thallus is first uninucleate (fig. 9) but very shortly the primary molem underaroes division. 'These divisions are simultineous, so that a large number of mitatic figures in the sinde stage may be fomd in the large sporangria (tigs. 12.13). 1)angeard was not certain whether division is direet or indirect, lut his figures indicate that it is mitolie.

After the thallus has attained its mature length, it divides by transverse walls into two to ten fairly equal segments (fig. 11). These soon separate at the septa, become free, and with further increase in lengtl and dianeter are transformed into either sporangia or ganctangia. Dangeard's description and figures snggest that dwarf unicellular thalli may also be formed as in Lagenidium and Myzocytium. The details of cytokinesis and sporogenesis a re not well known in sjote of 1)angeard's description. The incipjent sporangia usually possess several small racuoles whicll apjuarently coalcsce to form a large central one as they mature (fig. 13). and the nuclei lie in the primordial utrical surrounding the vacuole. 'The spores are doubtless dolinited by progressive cleavage as in other sporangia, and witl maturity become clavate and oricnted with the thick rounded end directed toward the exit tulhe (fig. 1t). 'I'he latter may le stright, curved, or bent at right angles to the surface of the sjorangium. As the neck of the sporangium jer forites the host wall and deliquesces, the spores are all forcilly cjected at one time or in successive groujes from the sporangium (fig. 15).

In some respects sexual reproduction is similar to that of Myzorytium and Lagena. Since conjugation is predominently lateral (fig. 16) Maupas helieved that most of tlic male and femile gametangia are segments of different tlaslli. Heterotlaallism lias not, however, leen definitely estahlished. Fnd to end or scalariform conjugation may also occur (tig. 18), which suggests that the renjective gametangia lave arisen from the sisme thallus. The segments which are to become grametangia do not usually increase much in size, and are frequently clomgate and cylindrical. Since the resting spore develops in the larger of the two gametangia and the content of the smaller is mobile, the two have been designated as male and [emald respectively. Lach sends wut a protuleranes toward the other as in some speceies of Spiroyyra and as these rome in comtact they fuse at the tips. 'I'le content of cach gametangium thon usually contracts toward this common camal, and as the intervening wall lireaks down the male gancte sluwly pisses over into the female gametangimm and fuses with the oojlasul. So differentiation of an eger cell and periplasm las so far leecu observed, liut the contraction of germ plasms toward the conjugition tulue seems somewhat similar to that descrilued by Zope in Lagenidium rabenhorstii. Furthermore, conjugation in Jrotascus is also similar to sexual reproduction in Lagena, with the excejtion that in the batter genus the gametangia are usually equal in size and indistinguishable, and the conjugation tule is formcd cxclusively by the male.

The \%ygote soon hecomes invested with a thick wall and goes into the resting condition (figs. 17-20). As noted ahove, Maupas called it a zygospore, while litzpatrick referred to it as an oospore. Since rejoroduction is to a slight degrec heterogimous, and the resting sporc lies free in the female gametangium, the latter's terminology is perhaps more deseriptive. The writer is nonetheless using the noncommital term, resting spore, for the time leing, since the relationshijus of Protaseus are still olsscure. No eytological study of sexual reproduction from fixed and stained material has yet been made, and it is not known whether the ginnetes are uni- or multinucleate at the time of fusion.

'The presence of the parasite does not hinder the activities of its host and produce any marked pathological effects until after two or three days. By this time, however, the nematode gradually loses its ahility to contract and move and hecomes slow ind heavy. I ater as paralysis becones more marked it undergoes tetanic contractions which last for a long time. In the end a final riolent contraction occurs which leaves the animal in a stiff, rigid, twisted position. In a short while it hegins to distend and straigliten out as deatli occurs.

P. SUBULIFORMIS Dangeard, l.e. 1906. t.e Bot. 9: 9.j6. I'ls. 1j-16.

I. subuliformis var. maupresii Maire, 1915, t3ull. Sue. Jist. Nat. Ifrique Nord. 6: 50 .

'J'hallus $5-10 \mu \times 100-100 \mu$; sporangia $6-7 \mu \times$ $16-110 \mu$. irregular ones $u\}$ to $26-28 \mu$ in diameter; spores 8-200 in a sporangium. $0.0-3 \mu \times 20-25 \mu$. apparently adhesive at the slender cond: ganctangia usually slightly smaller than the sporangia; resting spores $15-30 \mu$ in diameter. wall $1-2 \mu$; thick. (lior further details sec the generic analysis above.)

Parasitic in nematodes in linese (Dangeard, l.c.) ; Rhalditis teres, $R$. giardi, and $R$. dolichura in Mlgicrs (Maujas, '15).

IIaupas' attempts to infect ('osmarium s].. Closterium lunala, Cladophora sp., and Stigeodonium s]. as well as numerous mematodes including $D$ )iplogaster striatus, I). gracilis, Crphaloleus rigidus and 
Rhabditis monohystera with this parasite were unsuccessful, and his results suggest that $P$. subuliformis may have a limited host range.

It seems doubtful that Dangeard's species is different from Maupas' fungus, as Maire has suggested. The predominantly unicellular thalli which he describes and figures relate perhaps to segments of a longer thallus which have separated.

\section{MITOCHYTRIDIUM}

Dangeard, 1911. Bull. Soc. Mycol. France 27: 202.

This genus was crcated for a single intramatrical species, $\boldsymbol{M}$. ramosum, which parasitizes desmids of the genus Docidium. Dangeard regarded this species as intermediate between the Chytridiaceae and Ancylistaceae. but Butler ('28) was of the opinion that it should be included in the Cladochytriaceae, close to Catenaria. Couch's ('35) discovery of this species in North Carolina and his confirmation of the presence of rhizoids and posteriorly uniflagellate zoospores justifies Butler's view, in the author's opinion.

\section{RHIZOMYXA}

\section{Borzi, 1884. Rhizomyxa, nuovo ficomicete, Mes- sina.}

This genus has been fully discussed by the present author in his book on the plasmodiophorales. 1942, and need not he treated further at this point. See discussion under Myzocytium also.

\section{BIBLIOGRAPHY : LAGENIDIACEAE}

Atkinson, G. F. 1909. Ann. Mycol. 7 : 441.

Barrett, J. T. 1935. Phytopath. 25: 898.

Berdan, H. B. 1938. Mycologia 30: 396.

Bessey, E. A. 1937. Textbook of mycology. Phila.

Butler, E. J. 190\%. Dept. Agric. India I, no. 5: 1.

19:8. Ann. Bot. 42: 813.

Carter, H. J. 1856. Ann. Mag. Nat. Hist. Znd ser. 17:101.

Cejp, K. 1932. Rozprivy Ces. Akad. 42 cis. 3. 1933, Ibid. 43, cis. 9. 193.5, Tbicl. 15.

Chaudhuri, H. 1931. Areh. Protistk. 75: 472.

Cocconi, G. 1894. Mem. R. Acad. Sci. Inst. Bologna 4:361. Coker, W. H., and V. D. Matthews, 1937. North Amer. Flora 2, pt. $1: 17$.

Constantineanu, J. C. 1901. Rev. Gen. Bot. 13: 369.

Cook, W. R. 1. 1928. New Plı̣tol. 27: 2.13. 1933. Glamoran County Hist. Nat. 1: 213.

Cornu, 11. 1869. Bull. Soc. Bot. France 16: 222. 1870, Mbid. $17: 297$.

- 1872. Ann. Sei. Nat. 5th Ser. 15: 21. 1877. 13ull. Soc. Bot. France $21: 266$.

Couch, J, N. 1935. Jour. Elisha Mitch. Sci. Soc. 51: 293.

1941. Amer. Jour. Bot. 23: 70.4.

Dangeard, P. A. 1906. Le Bot. 9: 157, 207.

De 13ary, A. 1884. Vergleichende Norphologie der Pilze.

Deckenbach, C. 1903. Flora 92: 278.
Domjan, A. 1935. Folia Cryptog. 2: 31.

Fitzpatrick, H. M. 1930. Phycomycetes. New York.

Fritsch, F. E. 1903. Ann. Bot. 17: 619.

Gäumann, E. A. 1925. Vergleichende Morphologie der Pilze. Tiirich.

- and Dodge. 1928. Comparative morphology of fungi. New York.

Graff, P. W. 1928. Mycologia 20: 158 .

Gwynne-Yaughan, $\dot{H}$. C. I.. and B. Barnes. 1926. The structure and development of fungi. Cambridge. and ed. 1937.

Karling, J, S. 1939. Amer. Jour. Bot. 26: 518. 1941. Mycologia 33: 356. 1942. The Plasmodiophorales. New York.

lind, J. 1913. Danish fungi as represented in the herbarium of E. Rostrup. Copenhagen.

Lohwag, H. 1926. Arch. Protistk. 55: I.

Lotsy, J. I'. 1907. Vortr. Bot. Stammengeschichte. Jena. Maire, R. 1915. Bull. Soc. Mist. Nat. Afrique Nord 7: 50.

Nartin, G. W. 19:27. Nycologia 19: 188.

Matthews, Y. D. 1935. Jour. Elisha Mitch. Sci. Soc. 51: 306.

Maupas, E. 1915. Bull. Soc. Hist. Nat. Afrique Nord $\tau: 31$.

Maurizio, A. 1895. Jahrb. Nat. Gesell. Graiibundens 38: 9.

Minden, M. 1911. Krypt'fl. Mark Brandenburg 5: 1:3.

Mundkur, B. B. 1938. Fungi of India. Suppl. I.

Petersen, 11. E. 1910. Mycologia 8: 494.

Preissecker, K. 1905. Fach. Mitt. K. K. Gen.-Dir. Osterr. Tabakregie $5: 1$.

Rabenhorst, L. 186.1. Flora Europaea III.

Ramsbottum, J. 1915. 'Trans. Brit. Mycol. Soc. 5: 143.

Reinsch, P. F. 1878. Jahrl). Wiss. Bot. $11: 283$.

Saccardo, P. A. 1888. Sylloge Fungorum 7: 277. 1bid. A: 850. 1891, 1bici 9:348. 1919, 1bid. 21: 857 .

Scherffel, A. 1902. Nör. Közl. 1, 1902: 107-111.

- 1926 . A rel. Protistk. 54: $211,245,246$.

Schroeter, J. 1886. Coln's Krypt'fl. Sehlesiens 3: 225.

. 1897. Engler und Prantl. Die Nat. Pflanz'f. I, 1: 64.

Schultz-Danzig, p. 19:3. Schr. Siissw. -und Meereskunde $11: 173$.

\section{PLATE 25}

\section{Protascus subuliformis}

(Figs. 4, 5, 9, 10, 12-14 after Dangearr, '06; figs. 1-3, 7, $8,11,15-20$ after Maupas, "15.)

Figs. 1- Spores with refractive adhesive (?) content. Fig. 5. Early infection stage; content of uninuclcate spore passing into lrost.

Fig. 6. Later stage; parasite lying in host as an oval glohule.

Fig. 7. Heavily infected nematode with numerous attached spore cases and several lhalli within.

Fig. 8. Nematode with three elongate thalli.

Figs. 9, 10. Uni- and tetranueleate thalli.

Fig. 11. Elongate, curved, segmented, vacuolate thallus.

Fig. 12. Separation of multimueleate thallus segments and their transformation into sporangia.

Fig. 13. Mitosis in a sporangium.

Fig. 1t. Nematode with numerous sporangia, two of which are about to expel the spores.

Fig. 15. Expelled comma-like spores.

Fig. 16. Early stages in fusion of thallus segments connected by fusion canals.

Figs. 17-19. Zygospores.

Fig. 20. Nematode with numerous empty sporangia and zygospores. 
I'LA'TE 25

$\int_{1} 2$
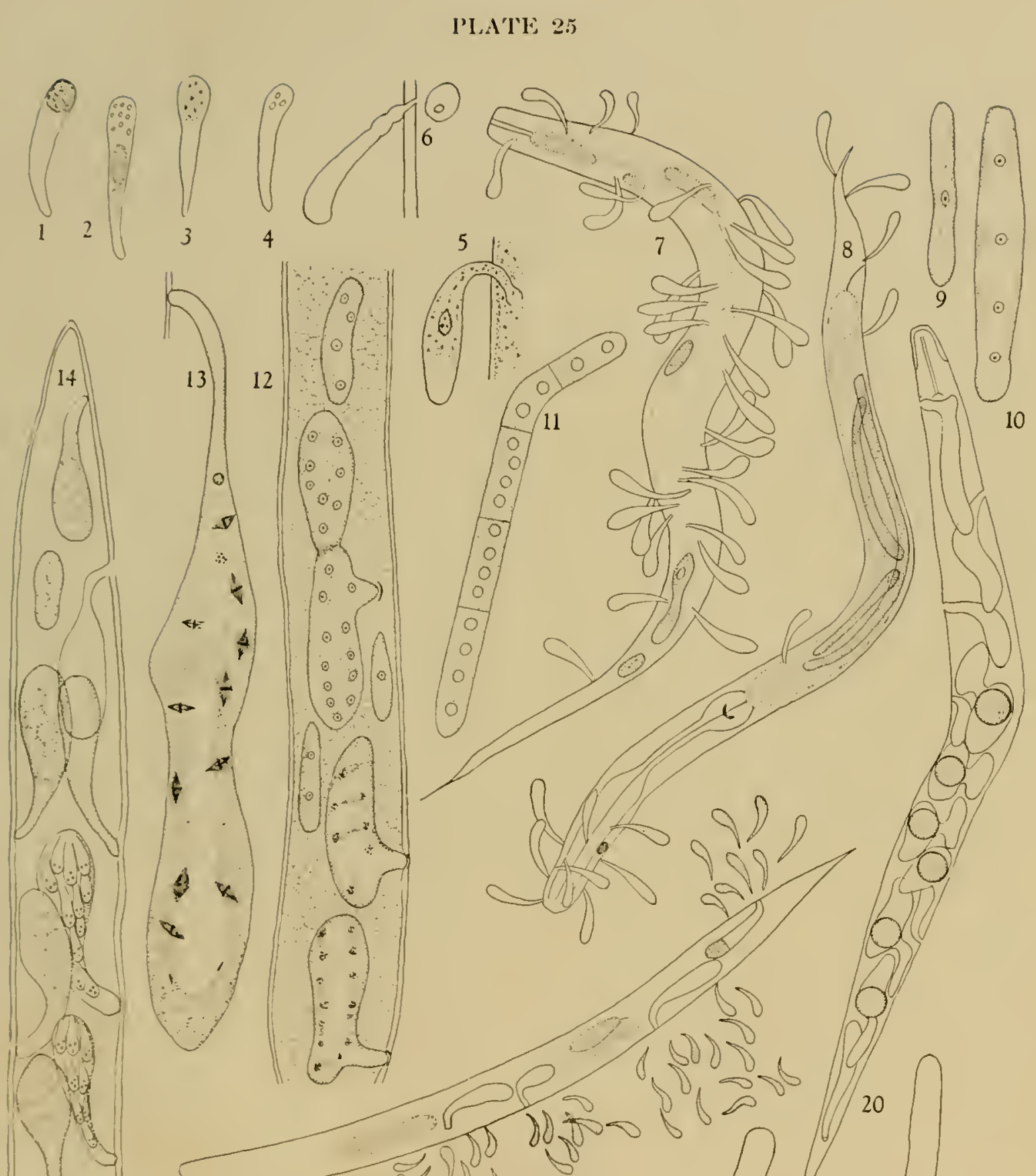

(n) $\rightarrow$
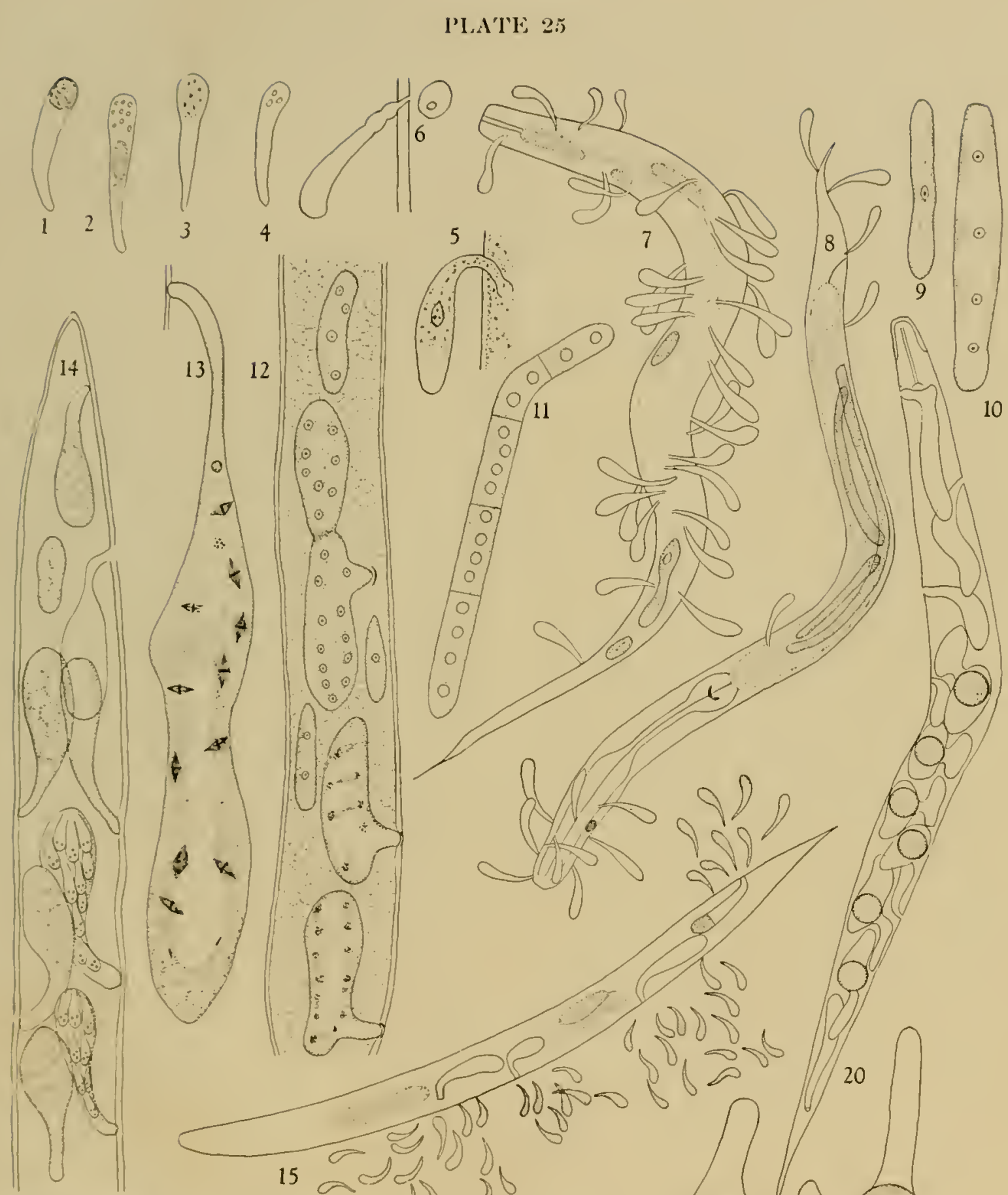

\section{5 acedo b}
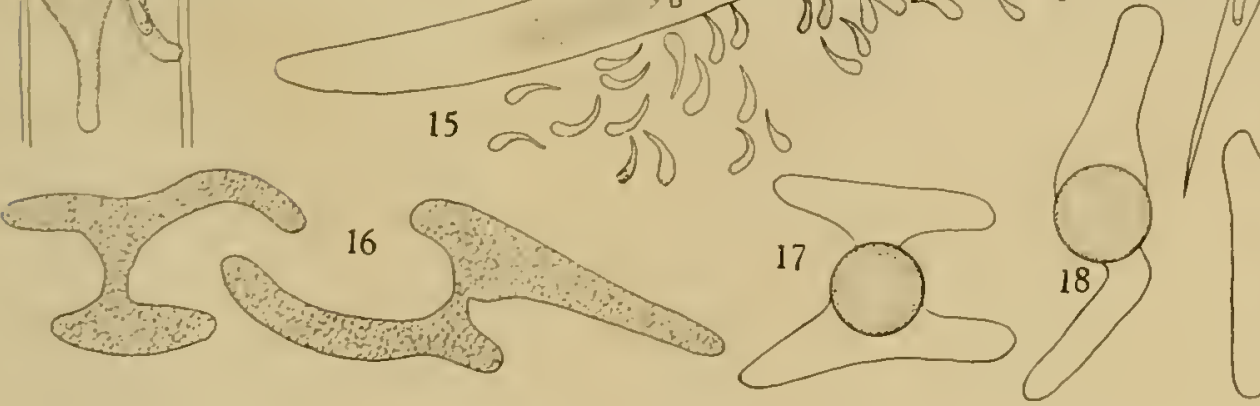
Serbinow, J. 1899. 'Trav. Soc. Nat. Petrograd 30: 255.

Skrortzow, B. W. 1995. Arch Protistk. 51 : 428. 19:37, Ibid. $57: 204$.

Sorokin, N. 1876. Ann. Sei. Nat. 6 ser. t: 63.

Sparrow, F. K. 193\%. Nycologia 24: 268 , 289. 1933, thid. 25: 513. 1942. Ihid. 34: 113.

Stein, F. 1851. Zeitschr. Wiss. Zool. $3: 475$. - 1854. Die Infusionsthiere und ihre Fntwickelungsgeschichte. Leipzig.

- 1859. Der Organismus der Infusionsthiere. Abt. 1: $165,189$.

Tavel, F. 1892. Vergleiehende Morphologie der Pize, Jena.

Thompson, G. F. 1934. Mỵeologia 20i: 118.
Tokunaga, Y. 1934. Trans. Sapporu Nat. Hist. Soc. 13: $2: 27$.

Turner, W. B. 189:. Kongl. Svensk. Veten.-Akad. Hand. $25,5: 1$.

Valkanov, A. 1931. Arch. Protistk. 73: 361.

V'uillemin, 1'. 1908. Prog. rei. Bot. 2: 1.

H'cttstein, R. 1935. Handb. der Sṣstenat. Bot. 4 ed. Leipzig.

Wildeman, E. de. 1895a. Ann. Soc. Niero. Belge 19: 63. $1895 \mathrm{~b}$, Ibid. 19: 215 .

1896. 13ull. Soc. Roy. Bot. Belgique 35: 7 .

Wolk, P. C. 1913. Mycol. Centralbl. 3 : 153.

Zopf, W. 1897. Hedwigia 18: 94.

\section{Chapter VII}

\section{Phylogeny}

Discussions of phylogeny at any given period of time must obriously be based on existing knowledge and data relative to the gronp of organisms in question. Relationships whieh thus seem obvions at present may be completely invalidated by future studies and diseoveries. Therefore, very few definite conelusions can be drawn at present about the origin and evolution of these holoearpie. biflagellate l'hycomycetes as a whole hecanse so little is known about the eritieal developmental stages of many of the genera and species. The present discussion will aceordingly be confined to pointing out similarities and differences letween these fungi, the lower organisms and higher fungi with which they appear to he related. Sinee it is not eertain that all of the families deseribed in the previous chapters eonstitute a natural phylogenetie series of elosely related speeies, differences in origin and relationship are to be expected. As has been briefly noted before, these relationships involve principally the Proteomyxa or Monadineae, Plasmodiophorales, Saprolegniales, and Peronosporales and are based on similarities or differenees in thallus structure, type of derelopment, relative lengths and position of flagella, diplanetism, presenee of cellulose in the cell walls, and type of sexual reproduction. Present day evidenee suggests very strongly that most of these holobiflagellomycetes are either remotely or elosely related to the higher Plyeomyeetes. However, it is not clearly evident whether they are primitive or reduced and degenerate, and many of the controversies on pliylogeny in the past have centered on these questions. While the views of the early mycologists in this respect do not relate to groups as specific as those ineluded in these so-ealled holobiflagellomyeetes, they nonetheless apply here in a general sense. DeBary ('81, '81), Tavel ('92), Gämmann ('26), Gäumainn and Dodge ('28), Mez ('29), Wettstcin ('35) among others regarded most of the biflagellate species as reduced and degenerate oomycetons fungi resulting from their assumption of a parasitic mode of life. On the other hand, Dangeard ('86, '06), Lotsy ('07), Vuillemin ('08), Atkinson ('09), Cavers ('15), Seherffel ('25), Fitzpatrick ('30). Cook ('28), Bessey ('+2), and others believed that they are primitive and represent an aseending evolutionary line. Lotsy and Bessey suggested that they may have been derived from the Isoeontae and unieellular Heterokontae, respeetively. Atkinson did not attacl mueh significanee to the number of flagella and derived them from the Chytridiales. Dangeard, Cavers, Scherffel, and Cook, however, believed that together with the Chytridiales they originated from the zoosporic Monadineae or Proteomyxa.

The evidenee bearing on the origin and relationships of these holobiflagellomycetes will now be eonsidered in greater detail. The provisional family, Woroninaceae, interpreted as a convenient dumping gronnd or a heterogeneous colleetion of genera which are quite probably unrelated, appears to be the nost primitive and stands somewhat apart from the other families beeause its vegetative thallus is reported to be plasmodial in strueture and mode of nutrition. As noted before, in IToronina the plasmodium eleaves into segments whieh are transformed direetly into zoosporangia or resting spores. These struetures may be united into eompact sporangio- and cystosori, respeetively, in $I T$. polycystis, while in $\dot{H}$. glomerata they lie comparatively loose and free. The striking similarity in type of development of these speeies to that of the Plasmodiopliorales is obrious. Zopf ('94), Maire and Tison ('11), and Winge ('13) and others early reeognized this similarity and stressed the relationship of $\Pi$. polycystis to Ligniera and otler genera of the Plasmodiophoraeeae. This relationslip was further emplasized ly Ledinglam's ('33, '39) and Couelı's ('39) diseoveries of Polymyxa and Octomyxa, respeetively. The lutter genus, particularly, is almost identical in life eyele to $W^{\circ}$. polycystis, as was stressed by the present writer ('12) in his book on the Plasmodiophorales. Sparrow ('12) ineluded Woromina in the latter order and discarded the family name Woroninaceae altogether. As has been stated already, futnre studies may possibly prove that $\boldsymbol{H}^{r}$. polycystis is a species of the Plasmodiophorales, hut so far as is now known, it differs in several respeets from the valid members of this order. In the first place, it is not definitely known whether the zoospores are iso- or heterocont and whether the flagella are lateral or 
anterior in position. Secombly. schimogom of the

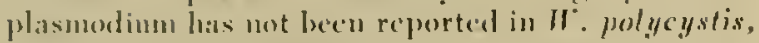
and mothing is known about the types of muclear divisions in the vegetative and sporogene ons thalli. Sellizonomy and the oceurrence of "promitosis" are chimed to le ontstanding characteristics of the Plismoroliophorale's. Thirdly, the sporangia and resting spores of $\mathbb{1}^{\circ}$. polycystis give a positive celluloses reation when tested with chloro-iodide of zinc. while those of the l'lasmodiophorales do not. liurthe rmore. in erermination the content of the zoospore enters the host directly through a penetration tube. leaving the empty spore ease on the outsicle of the hout iell as in Olpodiopsis, linzellopsis and other similar armera. In the l'lasmodiophorales. on the other hame. the zoospores are reported to enter the lost directly as a naked anowohid borly. How significant tlese minor difterences are in pliylogeny and whether or not they outweigh the sinilarities in thallus structure and type of development remains to he seen from future studies. Nevertheless. the presence or alsenee of collulose is regarded as fumdamentally significant ly many stmelents of phylogeny and evolution. Horonina glomerata differs from the previous speeies in several ways. Insteal of forming but one zoospore in germination as in W. polycystis and the plasmodiophoraceons species, tle resting spore functions as a sporangium and produces a large mumber of zoospores. lurtlermore, the plasmodium is animal-like in morle of mutrition, ac'eording to Kopf ('9t) and Scherffel ('25), and engulfs plastids, starch grains, and other solid bodies. This material is digested in well-defined lood vacuoles. and the extraneous waste material is discarden to the outside in preparation for sporogenesis. This type of feeding and digestion is characteristic of the Proteomya, and for this reason Zopf and sicherffel relegated $W$. glomerata to the zoosporic group of the Myxozoidia or Proteomyxil. Tluss. within the same genus, as IVomina is now interpreted. accur species with seemingly diverse relistionships. However, these differences of relationship may not prove to be as significant as they now alpear. because evilence is aecumblating which sugrests that certain species of the Proteomyxa. Plasmodioplorales, and IForonima may possibly be elosely related.

Turning to tle other two genera. Pyrrhosorus

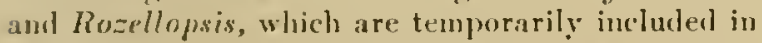
the Worminaceac, it hecones evident that the relattionships are not well defined. Koosporangia and resting spores apparently do not occur in P'yrrhosorus. lustead, the plasmodiun releaves into spore motluer cealls which unite into a sorus and later undergo three divisions, forming eiglıt free spores. The latter are transformed directly into biflagellate isocont zoospores. 1)espite these differences the presence of a plasmodium and sorus suggests some degree of relation to or parallelism in development with the Planmodiopliorales. Juel ('O1) was uncertain of the relationslip of Pyrrhosorns, hut lee emplasimed the striking similarity of its methorl of spore development to that of Tetramyara. As the writer ("12) lass already pointed ont. hard Orefo myara leen kuown at that tims. Juel would doulitless have emplusi\%(ed the relationship of his fungus witle the l'asmodiophorales even nume strongly. llinge: (13) also regarded it as closely rolistod to the Plasmorliopluoraceace and made extensive (2om)parisons hetween its life eyele and that of sorolpidinm. He considered the sporangiosori of the latter gemus is homologous with the sori ol spore mother eells of l'yrrhessorus and believed that the absence of walls arouml the spore mother colls is of mimor significanee. Cook ( 33 ), on the other liand, helieved that the relation of this gemus to the plisinodioplorales is very questionable.

The origin and relationships of the provisional genus liozellopsis are even more olscure. Compart or loose sporangio- and cystosori are unkmown, and the only significant characters which it has in conmon witl the two previous genera are its plasmodium-like vegetative thallus. which may or may mot undergo schizogomy or division, and biflagellate zoosporcs. Since the presence of a plasmodium las not been conclusively demonstrated in this gemus, the inclusion of $h$ ozellopsis in the same family witl IForonina and "yrrhosorus becomes even more questionable. However, the anteriorly biflagellate heterocont zoospores of $R$. simulans, according to 'Toknnalga's ('33) drawings, are strikingly sinilar to those of the Plasmodiophorales. but in infecting the lost they hehave like those of $W^{*}$. polycystis, Olpioliopsis, Eicirogella, etc. Insteal of entering tle host directly, they form an infection tube throngh which their content passes into the host eells. On the other hand, the strueture and development of the thallus and resting spores in the aseptigenous and septigenous species are identical to those of the mono- and polysporangiate species, respectively, of the clytrid genus. Rozella and Pringshpimella divica, as far as is now known. Whether this indicates nerely a parallelism in development from different ancestors or direct relationslip) is not certain. Aceording to Bessey"s ("12) theory of origin thromgh the retention or loss of the seeond flagellum, Rozellopsis is more primitive than hozella and P'rincesheimella and may have given rise to these genera liy the loss of one fagrellum. While this theory seems plansible, it is obrious that the loss of one flagellum. without change in position of the remaining one. from the zouspore of Rozellopsis would not lead dircetly to the distinctly posteriorly miflagellate \%oospore of Rozrlla and Pringsheimella, since hoth lingella in Rozellopsis aro roported to be rither latrersl or anterior in position. I.oss of one flagellum in h'. simnlans, for instame. would make the zoospore antoriorly unifagellate.

'The otler four families to be comsiclererl, mamely. the Fetrogellaceat. Olpidiopsidacenc, Sirolpioliaceace, and 1 , agendicliaceace. appear to he more closily related as a whole and constitute an ascending or descemling line, depending on which viewpoint one holds. The principal genera of these families con- 
SAPROLEGNINEEN-PERONOSPORINEEN-SERIES

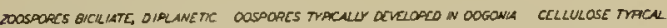

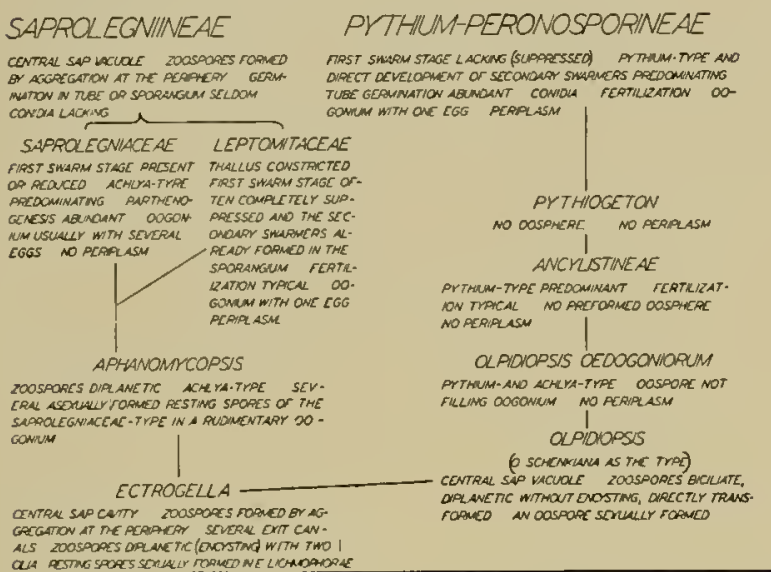

MONOBLEPHARIDINEAE

KOOSPORES UNCILATE NO GELLULOSE OOSPOAE GEVLLOAFO IN AN DOGONEM SACRMATOZOOOS

MONOBL EPHAROOACEAE MONOBLEPHARIS GONAPOONA

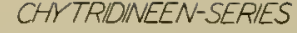

LNCHLTTE, ZOOSACRE MONOPLNTTC CELLLLOSE

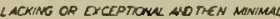

CHITRIDACEAE

NO CONTRA SW VMCUOLE 200 SPDESS POSTEAOATR UNCLLATE MOTON GR IOAG AND ONATWE UALCY DEVLLOACO, GEAMINAT SES TO FOFM 200 sapers

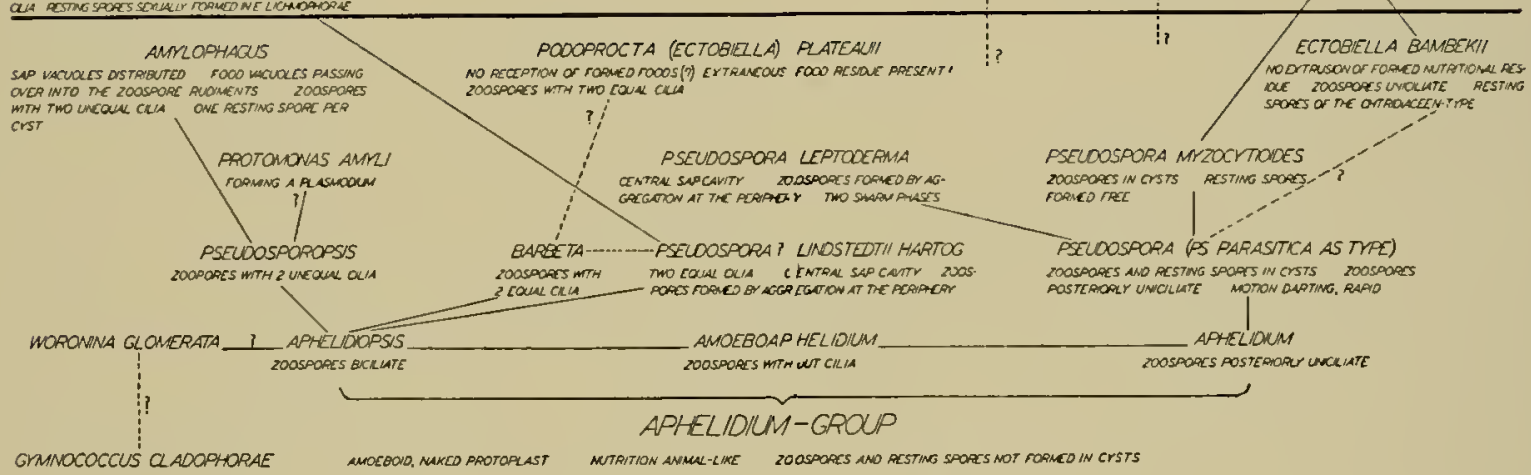

Diagras 1. Showing the origin of the Phyeomyeetes from the zoosporie Monadineae or Proteomyxa. After Scherffel, 25.

stitute the basis and starting point of what Scherffel ('25) earlier named the Saprolegniales-Peronosporales series of Oomyeetes, as is shown in diagram I. In his opinion, this series has four ontstanding charaeters which distinguish it from the Chytridiales on one hand and the MonohlepharidialesBlastoeladiales series on the other. These characters are: (1) biflagellate diplanetie zoospores whieh lack a large conspict:ous refringent globule; (2) grayish gramular appearing protoplasm and the presenee in the zoosporangium and oogonium of a large eentral sap eavity or vaeuole surrounded by a relatively thin parietal layer of protoplasm, and the occurrenee of simultaneous eentrifugal eleavage (hallung); (3) laek of motile male eells or spermatozoids and the produetion of sexual or asexual oospores in oogonia, and ( $k$ ) the presence of eellulose in the ("ell walls. Seherffel helieved that these eharacters indieate rlose aftinity within the series and that these lungi constitute an ascending evolutionary line originating in the zoosporie. Monadineae and culminating in the Peronosporiles. Although Seherffel presented more speeific and pertinent data in support of this riew, his theory is fundamentally the same ats that proposed ly Dangeard in 1886 and 1906.

Mez, on the other hand, eoncluded from his serum diagnosis method of determining affinities that the origin and relationships of the holobiflagellomyeetes are otherwise. He helieved that the Saprolegniales originated from the Siphonales near I aucheria and by reduction gave rise to the Lagenidiaceae, from whieh in turn was derived the Woroninaceae (in the broad sense of Minden) by further reduetion. However, his belief concerning the two last named families was not based on experimental data. because of the difficulty of obtaining suffieient material for serum analysis. Mez's riew is aecordingly seareely more than a revival of the reluction hypothesis of DeBary, Tavel, and other workers. More recently Bessey has suggested that the Olpidiopsidaeeae (interpreted as ineluding all of the biflagellate speeies except the Lagenidiaceae) as well as the Chytridiales have evolved from unieellular heteroeont algae throngh the loss of chlorophyll and the assumption of a parasitic mode of life, $\dot{A}$ s is shown in diagram 2, his theory of origin and relationships of the Phyeomyeetes is hased primarily on whether the second flagellum is retained or lost in evolution-the Olpidiopsidaceae and Lagenidiaeeae being derived from those aneestors which have retained both flagella.

If we examine elosely the data on phylogeny in these four fanilies we fincl, however, that they are rery incomplete and not so eonvineing as the abovementioned workers would have us believe. Beginning with the Ectrogellaceae, for instance, it is obvious 
that the four genera and apposuimately nine species which comprise this family are too poorly kmown to warrant definite comelusions for the prescout. As has beren prointed out ciarlicer, the type semus lietrogrlla was formerly includel in the cleytrid tamily. Olpialia-

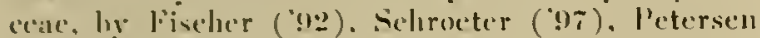
(0.)). Iimden ('I). (iwyule-Vaughan and barnes (26. 37 ). litzpatrick ( $(30)$, and otlers, although Zopf ('st) empliasized its similaritic's to tho I.agenidiaceac (Ancylisteen). Siclerffel's ("2.5) discovery that the zoospores are hiflagellate and diplanetice necessitated the remosal of this genus from the chytrids. and la accordingly made it the basis of a new fimily.

"l'he sliape and size of the thillus offer no definite sugerestions about to the origrin of the Ectrogellaceate beenuse it mis he oval, spluerical, ellipsoid. or elongate, as in many of tlue otluer families. Nevertlueless, the erayislo griumlar apjearance of the protoplasm, the presence in mature sporangia of al large central vacuole surromoled hy a parietal liacr of protoplasm, the method of cleaviage or zoospore delimitation (ballung), and the suhseguent accurrenee of the lomogeneons stage following cleavage indieate direct relationship, witl the Saprolegniacene, according to scherffel. While such characters alone are not always indicative of elose affinity, they are supported in this case ly the diplanctic hehavior of the zoospores. As scherffel has shown in Ectroymlla, the primary swarmers are usually apically biflagellate and isocont and swin directly away for a brief period before encystim as in Saproleymia, or they may he afigellate, glide out, sud encyst in a cluster at the moutl of the exit tube as in dichlya. 'The secondary swarmers in lictrogclla are lemon-shaped and pyriform, usually with a rentral groove, laterally biflagellate and lieterocont with the sloorter and more active fagellum extending forwarl in swimming. In the erenus Eurychasma the primary swarmers may encyst around the inmer periphery of the sporangium as in Jiclyuchus, but the sesondary zoospores do not emerge through imlividual pores in the sporanginm wall as in the latter genus. Instead, they emerge from the cysts into the central portion of the sporangium and then swin ont througli the exit tuhe. In l:urychasmidium and A phanomycapsis the primary zoospores are reported to heluave like those of Ifhlya and Iphanomyecs. Secondary zonspores. luwerer, have not beeil observed in linrychasmislium.

Thus, in the family Fetrogellaceat the zoospores may exhibit striking similarities in hehavior and structure to tluse of Sa prolegnia, Ichlya, A phanomyces and lJict yuchus. Jurtlermore. in Éctrogella, Aphanomyeopsis, and liurychasma may lo found the same degree of reduetion of the primary swarming period as oceurs frems Saprolegnia through Achlya and I phanomyces to Dictyuchus. Whetlice. on tlese srounds, the memlers of the lictrogellaceac are to be considered primitive or reduced and degenerate silprolegniaceouns species is not clenrly evielent. Mrcologists who alliere to the reduction hyothesis

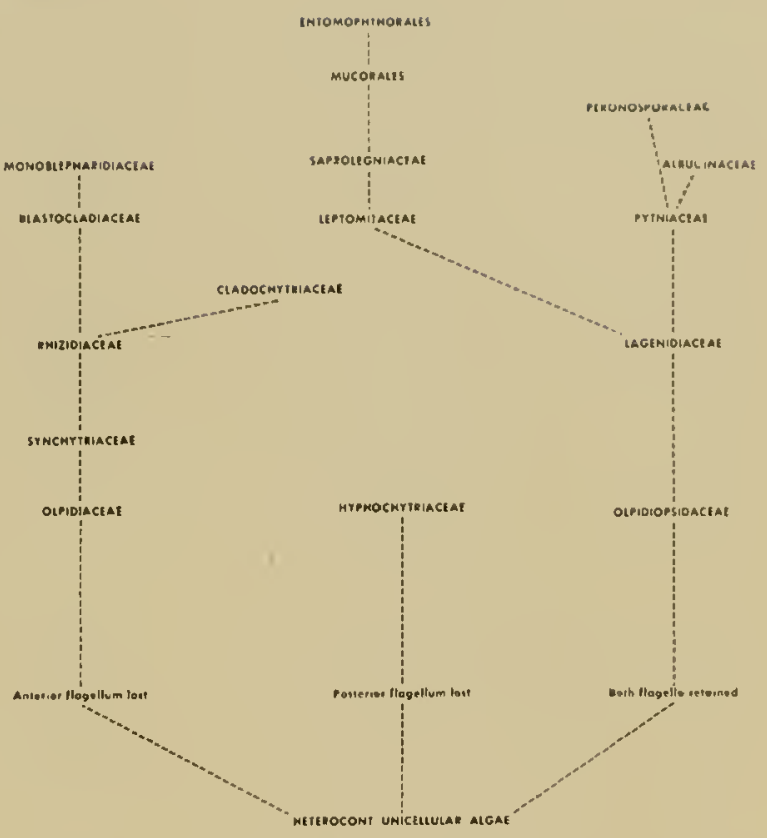

Drackan 2. Phylugeng of the Phycomycetes based upon the theory of their origin from unievilular algae. Ifter Bessey 191?.

may well argue that the thallus of this family las undergone reduction while the zoosjores have retained their diplanetic behavior. Siellerffel. however. regarded them as primitive and lecld that the type of diplanetism exhihited is derived from the l'roteomyxa or Monalinease instead of the Siaprolegniales. Ii line with his beliel that the Plyycomycetes in general are derived from the Monadineace as shown in diagram 1, he accordingly concluded that Ectrogella and I phanomycopsis may have originated Irom biAlagellate leterocont genera similar to I phelidiopsis, l'seudosporopsis, and Amylaphayus and possil.ly inlerited their diplanetic labit from an ancestor like l'seudospora leptoderma. He also believed that the large contral sip cavity or vicuule present in \%oosporangia is a relic of a protemyxean ancestor.

On the hasis of the type of sexual reproduction seluerffel furtler helieved that lictrogella may he comnected on one hand with the Silprolegniacene and I,ejutomitaceac thromgl A phanomycopsis and on the other land with the l'erouosporaceace thromgl o dpidiopsis, the I agendiaceate, and P'ythiogeton. 1lowever, is has been emplasized betore, the oceurrence of sexual reproduction in the Fetrugellaceace lias not been conclusively proven. Resting spores are known in omly thece species. In l\% perfarans they ajplear to be nothing nure than regetative thalli which have conested nud descloped thick walls. Selereflel regardiel the resting spore of $l:$ Licmo pharar as an oo pore in a rudinentary oogonimu, altlougl, he: did not actually olserve sexual fusion. Is the present author has alrenely pointed out. this resting spore may possibly he nothing more than the 
contracted and encysted content of an irregular, lobed thallus. In A phanomycopsis bacillariacearum one or more asexual resting spores are formed in a thallus or a segment thereof, and Scherffel accepted this as an indication of even closer relation to the Saprolegniaceae. Obriously much more study on the occurrence of sexuality in this family is essential before this character can he used as a basis of comparing relationships. Nevertheless, Scherffel's helief that there is a close affinity between the Ectrogellaceae and the Saprolegniaceae has been rather widely accepted, although subsequent workers have not been certain ahout whether the former family represents an ascending or descending series in the evolution of the Phycomycetes. Gaumann ('26), Gaumann and Dodge ("28) included Eurychasma and Ectrogella in the Ancylistaceae (Lagenidiaceae) and emphasized their close relationship to Lagenidium, Myzocytium, and the Saprolegniaceae. Sparrow (33, '36) included Ectrogella and Aphanomycopsis in the Saprolegniales without committing them to any particular family, but in 1942 he placed them in the Ectrogellaceae and made this family the first and most primitive of the Saprolegniales. Coker and Matthews ('37) also included the Ectrogellaceae in this order next to the Saprolegniaceae.

Very little can be said about the origin and relationships of the Sirolpidiaceae at present, hecause this family is even less known than the Ectrogellaceae. It has no particularly outstanding family characteristics which relate it distinctly to any of the other groups. The genera Sirolpidium and Pontisma were formerly included ly Petersen ('05) in the Holochytriaceae of the iIycochytridiales, althongh he had discovered that the zoospores of the type species, S. Bryopsidis, are biflagellate and not chytrid-like. His findings were confirmed hy Sparrow ('3t. 36) who later ('12) proposed the family Sirolpidiaceae for these genera and placed it in the Lagenidiales between the Olpidiopsidaceae and Iagenidiaceae. Whether or not present-day knowledge warrants this position is obviously open to question, hut the nature of the regetative thallus of the Sirolpidiaceae nevertheless suggests such a relationship. The thallus has a tendency to become elongate, filamentous. and somewhat mycelioid and may fragment into sections like those of some species of Lagenidium and $M y z o c y t i u m$. On the other hand. the thallus may sometimes be unicellular and olpidioid like those of the Olpidiopsidaceae. These likenesses are also correlated with similarities in the general appearance of the protoplasm, the presence of a large central vacuole hounded by a parietal layer of protoplasm in the mature zoosporangium before cleavage, and the method of cleavage. Size. shape, and structure of the thallus, however. are vegetative characters which rary markedly and by themselves are not always significant phylogenetically, so that too much empliasis must not be placed on thenr.
So far as is now know the zoospores are not diplanetic, and in this respect do not show affinity with the Ectrogellaceae or the diplanetic members of the Lagenidiaceac. According to Sparrow ('3.t), the zoospores of S.lagenidioides are strikingly similar in behavior and appearance to those of Rozellopsis inflata, while in Petersenia lobata the late cleavage and early zoospore stages resemble those of Pythium. Thus, aside from their arched, pyriform or slightly reinform shape and the presence of two flagella the zoospores offer few clews to the relationship of the Sirolpidiaceae. Comparisons on the basis of type of sexual reproduction camnot be made because nothing is known about sexuality in this family. Resting spores are unknown in most species, and in those for which they have been reported they appear to be nothing more than regetative thalli which have encysted and hecome thick-walled.

IIost species of the family. Olpidiopsidaceae are fully known as to life cycles and development, and the indications of relationship are accordingly more clearly defined. In thallus structure and appearance all species show a striking parallelism to the olpidiaceous chytrids, and for this reason they were first included in the Olpidiaceae and later in the Pseudolpidiaceae and Woroninaceae hy most mycologists and designated as biflagellate chytrids. This close resemblance in regetative structure is probahly due to convergent evolution and may not be indicative of affinity. Sharply defined diplanetism does not occur in this family except in Olpidiopsis Oedogoniorum and P'ythiella rernalis-two species which possibly do not helong in the Olpidiopsidaceae. In most species of Olpidiopsis, however, the zoospores may come to rest, retract their flagella, hecome amoeboil, and then remain quiescent for a while, but they do not encyst. After a short while flagella are formed again, and the zoospores resume their motility. The insertion and position of the flagella appear to be the same during both motile periods. Butler ('07) compared this interruption of motility to diplanetism in the Saprolegniaceae, and later Scherffel ('25) described it as diplanetism without encystment. Whether or not the behavior of these zoospores is to be regarded as evidence of primitive and rudimentary diplanetism which foresladows the development of true diplanetism in the Ectrogellaceae, Lagenidiaceae, and Saprolegniaceae is, of course, a debatable question. In O. Oedogoniorum, as noted hefore, true diplanetism has been reported by Scherffel, but the primary swarming period may loe reduced to nothing more than the emergence of the zoospores and a slight heating of the flagella. Occasionally the entire content of the sporangium may emerge as a protoplasmic mass and then undergo cleavage into zoospores on the outside as in Lagenidium and Pythium. A sinilar beharior was occasionally noted hy Coker ("23) in O. Saprolegniae. In $P$. vernalis the primary swarmers are aflagellate and merely glide out of the exit tube, near the mouth of which they encyst. The hehavior of the zoospores in these three species ranges from that of 
Ichlya to Tagenidium and Pythium. Is noted before. howerer. (). ()edogoniormm may possilbly be a speceices of Lagenidium while l'. zernalis may relate to anotlucr family. In these e'sents, the acemrence of truc diplanetism in the ()lpidiopsiclace ace remains to be comelusively clemonstrated. Su far nothing is known of its acenrence in l'sendosphaerita and Blastulidiopsis. "lhe Hagella of Olpidiopsis, partieularly of (). Siaproleguiae, are structurally similar to those of the Isagenidiaceace Sitprolegniales and Peronomporales. aceording to Conch ("H). ()ne of the flagella hears hairs or tinsels. while the other is of the whip lash type.

Except for Psendosphaerita, which is a doubtful member of this family. the appearance of the vacuolate protoplasm and the method of zoosporogenesis of mont species are rery similar to those of the reduced members of the I.agenidiaceac. and unless the type of sixual reproduction is observed it is difficult and almost impossible to tell the species apart. On these grounds then the Olpidiopsidaceat and Lagenidiaceac appear to be directly relaterl.

To many myeologists the type of sexual reproduction exhibited by the Olpidiopsidaceac is primitive and indicates an even (doser relationship to the Lagenidiaceac. In Olpidiopsis the degree of sexuality varies considerably in the same and in different speeies. and sex does not appear to he well established for the genus as a whole. The resting spores (oospores?) in some species are entirely asexual or parthenogenetic and appear to he nothing more than encysted. thick-walled regetative thalli, while in other species. O. Achlyae, for example. 75 per cent of them ma he parthenogenetic and the remainder zygotic. At the other extreme are species in which tile spores are 100 per cent zygotic. liurther evidence of rarialility in degree of sexuality is shown hy some partially parthenogenetic speeies in whieh only a portion of the male gamete fuses with the female. Also, one male ganete may ocoasionally "serve" two females, or one female may le fertilized by two to eiglit malc gamctes. Furthermore. exeept for size differences. the gametes are not markedly differentiated as such. Structurally, they do not apipear to be very different from ordinary vegetative thalli or sporangia and are morphologically equivalent to these structures. The male thallus is usually smaller than the female. hut occasionally the two are equal in size. Sexual reproduction in the Olpidiopmidaceace is, nevertheless. predominantly leterogamons. However. no egy cell or ouspore is differentiated in the so-called oogoninu in preparation for fusion. and except for the questionable species, O. Oedogoniorum, the oospore completely fills the thallus in which it develops. The type of undifferentiated sametes together with the great variability in degrce of sexual expression in Olpidiopsis suggest very strongly that this gemus and other members of the Olpidiopislaccare are primitive but on the otleer land they ma! erfually werl indicate reduction and degeneration. Sonetheless. Barrett. Cavers. Sicluerffel. Cook. and others regarded Olpidiopsis as prini- tive. Cavers and Cook alerived it from the Olpidiaccac in the Chytridiales, hut Sohorffel helieved that it originated froun an kirtrogella-like ancestor (diagrim 1). He regarded (). Schenliana as representative of the genus as a whole. and lirom such specie's erolution proceseded along the line of (). Oedogonio$r u m$ to the Aneylistincate (lagenidiaceac). 'T'le last mamed species. according to him, is very significant phylogenetically sinec the oospore lies free in a resicle or rulimentary oogonimu and is difficult to distiuguish from species of Lagenidium, particularly L. Oedogonii. In Pythiella rernalis sexual reproduction resembles that of (). schenliana hut differs from that of Olpidiopsis in general and the lagenidiaceac hy the partial differentiation of an egon cell in the oogonium and the presence of a small amount of periplasm. By these characters $P$. vernalis resembles species of $\dot{l} y$ thimm with which it may possilsly be closely related. Sclierffel's interpretation of the relationships of Olpidiopsis and related genera has been followed very closely by Sparrow (' 12 ) and Bessey ('12). Sparrow, as noted hefore, included the Olpidiopsidaceat in the langenidiales.

'The Lagenidiaceae is the most complex group of the lolobiflagellomycetes and is generally regarded as the climax family. Due largely to the fact that many of the species are incompletely known. this family has undergone the usual vicissitudes of classification and in mycological literature may be found in rarious relations to the Archinycetes and higher Oomycetes. The similarities of $M y z o c y t i m$ and Lagenidium to reduced speeimens of Pythium were so striking that Schenk ('59). Pringsheim ('58). and Walz ( 70 ) at first included the type species of these genera in $P$ 'ythium. Since that time a great many mycologists have recognized this close resemblance to the Pythiaceae and included the Lagenidiaceae among the higher Oomyectes, but as in the case of the other families previously diseussed these workers were not in agreement whether this family represents an ascending or degenerating line. The view points of many workers were influenced by the generally lueld belief that Aneylistes and other similar non-zoosporie genera. were closely related to the lagenidiaceac. Had they known that ducylistes and probably other genera also are members of the Entomophthorales, their interpretations would doubtless have been different. The fact that their viewpoints provided for Incylistis must be loorne in mind re ative to any criticisms which are made below.

De Bary ('8.). Schroeter ('86). Tarel ('92), Butler ('07), Clements ('09). Sicherffel ('25). Clements and Shear ('31). Wettstein ('35). Sparrow ('36.' '20), and others included the I agenidiaceac (Ancylistacene) among the Omnycetes in close relation to the Pytliaceac and l'eromosporaceac. hut Bessey ('37) and Coker and Mattlews ('37) rogarded it as a family of the Saprolegniales (ianmann ('25) and (Baumann and Dodge ('28) also included the Iargendiacene: in the Oomycetes lout discussed it as a fanily lotweren the Blastocladiaceac and Saprolegniaceac. De Bary and Tavel 
were of the opinion that it embraces only reduced and degenerate species which have arisen as the result of sulmersed parasitism-a riewpoint which has been revived by Gaumann. Gaumann and Dodge, and Mez. However, the majority of students of this group, including Schroeter ('97), Minden ('I1), Atkinson ('09), Cavers ('15). Scherffel ('25), Cook ('28), and Fitzpatrick (' 30 ), believed that this family constitutes an ascending series which has given rise to various groups of the Plycomycetes. Atkinson related Lagenidium to the chytrid Polyphagus and postulated that the Lagenidiaceae may have originated from certain species of the Rhizidiaceae and in turn led to the development along more or less parallel lines to the higher Oomycetes and Zygomycetes. In this connection it may he noted that many rears earlier Zopf ('8. p. 190) suggested that Rhizidiomyces apophysatus may be a type of species which relate the Rhizidiaceae with the Ancylistaceae (Lagenidiaceae) and Pythiaceae. While Cavers believed that the Phycomycetes originated in the Proteomyxa. he thought that the Ancylistineae (Lagenidiaceae) are derived from the Chytridiales and lead to the Peronosporaceae. Scherffel, as noted before, believed that the Lagenidiaceae developed from Ectrogella- and Olpidiopsis-like ancestors and is comected with his Pythium-Peronosporales series through Pythiogeton (diagram 1). Lagenidium C $y$ lotellae, in his opinion, is a connecting link hetween Ectrogella and the Lagenidiacene (Ancylistineae). Cook regarded the Ancylistaceae (Lagenidiaceae) as intermediate between the Chytridiales and Oonycetes proper and believed that it may have given rise on one hand to the Saproleguiaceae through the Blastocladiales and Leptomitaceae, and on the other hand to the Peronosporaceae through the Pythiaceac and Albuginaceae (diagram 3). Inasmuch as the

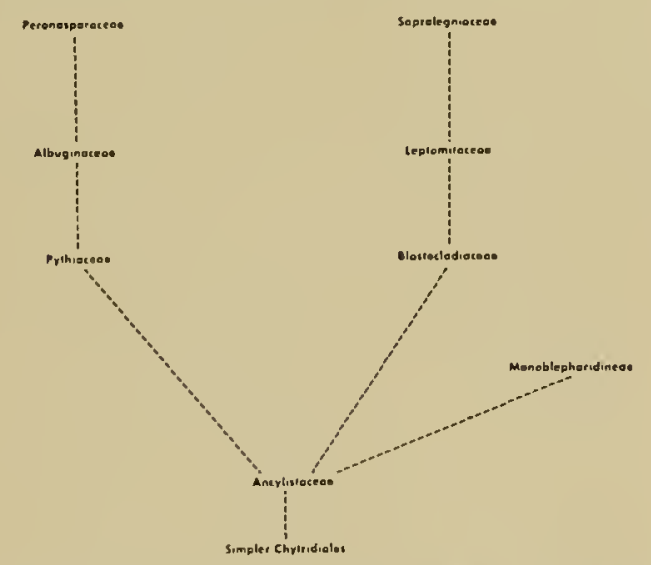

Diagham 3. The origin of the Ancylistaceate (Lagenidia(ceae) and its relation to the higher Oonycetes, according to Cook, 1928 .

zoospores of the Blastocladiales are uniflagellate and both gametes are motile. it is difficult to conceive how this order has arisen from the Lagenidiaceate.
Present day evidence indicates that the Blastocladiales may have originated directly from the Chytridiales. Sparrow (12) placed the Lagenidiaceae at the top of the Lagenidiales next to the Peronosporales, suggesting therehy that it may have originated from the Olpidiopsidaceae and Sirolpidiaceae. Bessey ('12) likewise derived it from the Olpidiopsidaceae and suggested (diagram 2) that it may have given rise in a more or less direct line to the Pythiaceae. Albuginaceae and Peronosporaceae on one hand and to the Leptomitaceae and Saprolegniaceae on the other.

Having reviewed briefly the various views on the pliylogeny of the Lagenidiaceae. let us now examine the data on which they are based. In size and shape the thallus of some species of this family resembles the mycelium of the filamentous Oompcetes, but in other species it is like that of the Olpidiopsidaceae. These characters, therefore, do not always afford a fundamental basis of relationship. lischer and Lotsy, nevertheless, used them and the holocarpic nature of the thallus as the chief grounds for including the Iagenidiaceae in the sub-order Ilycochytridineae, following the Olpidiaceae and Sychytriaceae. At that time few species with extensive, filamentous, mycelioid thalli were known so that the oral, ellipsoid or tubular, irregular, rermiform and elongate shapes were regarded as more characteristic of the fanily. Since then species like Lagenidium marchalianum, L. Closterii, L. giganteum, etc., have been described, the thalli of which can liardly be distinguished from the nycelium of Pythium. Conversely, reduced, holocarpic. relatively short, rermif orm and umbranched thalli may rarely occur in Pythium, Achlya, etc., so it is obvious that within certain limits size, shape, and extent of thallus are not always of fundamental value in judging aftinity.

In methods of zoosprorogenesis and the behavior of the zoospores after emerging. several lines of relationship are suggested. The majority of species slow distinct pythiacous tendencies hecause the prinary swarm period is suppressed and lacking. The protoplasm emerges from the sporangium and nndergoes clearage on the outside with or without a surrounding resicular memhrane. Lagenidium Oedogonii and Lagenidium s]s. Conch, on the other hand. exhibit a combination of Pythium, Saprolegnia and Achlya characteristics. In the former species the zoospores may be formed extramatrically in a resicle as in Pythium or within the sporingium and then encyst at the nonth of the exit tube after emerging as in Achlya. In the latter species they are formed in a vesicle lut after swimming about for a short while they encyst. Within one to three hours, they emerge from the cysts and become motile again as in Saprolegnia. In $\dot{L}$. Cyclotellae, however, the zoospores are formed in the same manner and behave Jike those of Olpidiopsis and some species of Ectrogella.

In shape, structure, position of the flagella, and type of swimning the zoospores of most species are essentially like those of Pythium and the secondary 
swaruers of Saprolegnia and other related generat In L. Cycletellae, however, they are more similar to those of Fetrouglla, while the markedly heterocont \%onspores of $l$. ene'ans and $V_{y}$ zoryfium, de-

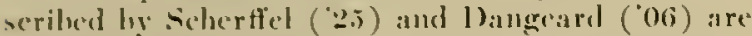
wome what like these of (). Ricciae, O. irregularis, I'sendelpidinm (ilenudineanum, I'. Sphaerita, and Psendosphaterita. Additional evidence of relation-

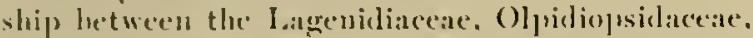
siprolegniacere and l'eronosporacene is suggested liv the fiset that the zouspores of liesticularia and Iyzorytimm and probalily other genera have one tinsel and whe whip lash trpe of flagellum.

lu exusl reproduction some species of the Lagenidiaceate may perhaps slow a slight adranee over that exhibited by the Olpidiopsidaceate by the fact that the oospore lies free in the oogonium and the grametangia are slightly more differentiated. In species of Lagenidium the oogonium is usually larger, more vesicular aud frequently harrel-shaped. while the antheridium is tubular and elongate. In 1.. enecans, for example. the antheridium may be closely applied to the oogoniun as in the siaprolegniaceate, according to seherffel. In other uenera like Myzocytium, Lagena and Resticularia, however. the gametingia are less differentiated and often appear to le nothing nuore than potential sporangia, with which they are morphologically equiralent. In no gremus is an egg cell differentiated in the oogonium in preparation for plasmogany. nor is periplism present. In hoth of these respects the lagenidiaceate differ from most of the l'eronosporales. lut slow some resemblance to the Saprolegniaceae by the absence of periplasm. The contraction of the ooplasm during plasmogamy in $L$. rabenhorstii may perhaps furesharlow a tendency toward differentiation of an egg cell before fertilization. That some differentiation does oceur in the cogonium and antheridium is suggested hy I)angeard's report that the supermumerary nuclei in II. zermicolum degenerate and only one from each ganuetangium functions in karyogamy as in species of the Peronosporales. Only one species of the I.agenidiaceate has been studied artologically in this respect. and whetleer or not this type of nuclear behavior is characteristic of the family as a whole remains to be seen. Tlie so-called aospores are nevertheless similar in appearance and structure to those of the siaprolegniales as well as the resting spores of many chytricls and species of the P'roteonyas.

Since the gametangia and gametes are not highly differentinted, Atkinson. Barrett. Conk, and others regurded sexual reproduction in the lagenidiacene as a generalized omnectous type with tendencies in more than one direction. Atkinson in partieular emphasized the isogamous and zygomycetous potentialitics and their relation to the origin of the: Zygumyectes from this family. As noterl previonsly. sexual reproduction in Resticularia, Lagmena, and Lagenidium sacculoides is isoganums. which lends support to the hypothesis that the \%ygomycetes also may have originated from lagenidiacous ancestors.
It is apparent from this discussion of origin and relationshipes that the so-eallecl hololitlagellomycetes have some chanacteristic's in (ommon with the Protomyxal. Plasmodiophorale's. Clyytridiales, Saprolemiales. l'eronosporales. and \%ygomyectes. As to their origrin. three principal theories have been proposed: (1) that they are reduced and degenerate ommectes resulting primarily from submersed parasitisn: (2) that they have been derived from heteroeont unicelhular algate through the loss of chlorophyll and the assumption of at parasitic mode of life, and (3) that they have originated from simpler fungi like the Cluytridiales or the more prinitive Proteomyxa. Their resemblance to the Chytridiales apparently is due more to parallelism of development or convergent evolution than close relationships. The genera included in the provisional lamily Woroninaceate show varying degrees of similarity to certain protemyxean species and the Plasmodiophorales ly their mode of nutrition and the presence of plasnodia and sori. The remaining families, on the other liand, exhibit marked Oomycete relationships ly their diplanetic zoospores aud predominantly heterogamous type of sexual reproduction. These atfinities involve principally the sitprolegniales and Peronosporales.

\section{BIBLIOGRAPIY: PIVLOGENY}

Atkinsun, G. F. 1909. Ann. Myeol. $7: 4+1$.

Barrett, J. T. 19]2. Am, But, 26: 209.

Bessey, F. A. t937. 'Pext-book of Mycology. Philadelphia. - 1913. Mycologia 34:365.

Butier. E. J. 190\%. Mem. Dept. Agric. India 1, no. s: 132. Cavers, F. 1915. New Phytol. It: zNo.

Clements, F. E. 1909. 'The genera of fungi. Minneapolis. and C. L. Shear. 1931. The genera of fungi. Minneapolis.

Coker, W. C. 1923. "The Saprolegniaceac, 1'. 184.

- and $\checkmark$. Matthews. 1937. North American Flora 2 pt. 1: $1 \%$.

Cook, W. R. I. 1928. Sew Phỵtol. 27:30\%.

1933. Arch. Protistk. 80): 223.

Couch, J. N. 1941. Amer. Jour. Bot. 38: 709.

.I. Lether, and $A$. Whiffen. 19:39. dour. Elisha

Witchell Sci. Soc. sis: 399

1)angeatrel, P. A. 1886. Ann. Sci. Nat. 7 scr. 4: 376. t906. l.e But. ": tsi.

1) Bury, A. 1881. Bot. \%eit. 39: 1.

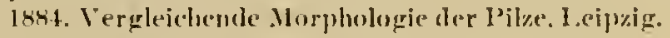

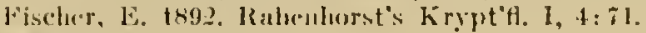

Fit\%utrick, H. .1. t930. The lower fungi-Phyconycetes. New Sork.

(Yiumann, E. A. t926. Vergleichende Morphologie der l'il\%, Ziirich.

- and C. W. Dodge. 19:k. Comparative morpholugy of fumgr. Xew York.

Gwyne-Vanghan, H. (. I., and B. Barmes, 1926. The strueture and developument of fungi. Cambriglge. जnel ed. $193 \%$.

Juel, 11. O. 1901. Jih, K. Sversk. Vet.-Akad. Iland. 26, aftl. $111, m, t t: 1$.

Karling, J. S. 1942. The Plasmodiopluorales, Xin Jork.

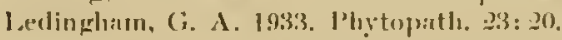

___ 1939. Canadian Jour. Ke:s. C, $17: 50$.

Iatsy, .T. 1'. 1907. Vortrigg ïbor botanisclw Stammengeschiehte $t: 118$. 
Maire, R., and A. Tison. 1911. Ann. Mycol. 9: 210.

Mez, C. 19:9. Schr. Königsberger Gelehrten Gesell.Naturw. Klasse 6: 1 .

Minden, M. 1911. Krypt'fl. Mark Brandenburg 5: 248.

Petersen, H. E. 1905. Overs. Danske Videns. Selsk. Forl. 1905 , no. $5: 46.5$.

Pringsheim, N. 1858. Jahrb. W'iss Bot. 1: $987,305$.

Schenk, 1859. Verh. Phys. Med. Gesell. Wurzhurg 9: 2 \%.

Scherffel, A. 19:5. Areh. Protistk. 5:38.

Schroeter, J. 1886. Cohn's Krypt'f. Schlesiens 3: 235. I : 70 .

Sparrow, F. I. 1933. Mycologia 24: 530.
1934. Dansk. Bot. Ark. 8, no. 6: 1.

1936. Jour. Linn. Soc. London $50: 461$.

1942. Mycologia 34: 113.

Tavel, F. 189:2. Vergleichende Morphologie der Pilze. Jena.

'Tokunaga, Y. 1933. 'Trans. Sajporo Nat. Hist. Soc. 13: 20.

Vuillemin, P. 1908. Progr. rei Bot. 2: I.

W'al\%, J. 1870. Bot. 7eit. $28: 556$.

Wettstein, R. 1935. Handbuch der Systematische Botanik, th ed., p. o04. Leipzig und Yienna.

Winge, O. 1913. Ark. f. Bot. 12, no. 9:26.

Zopf, W. 188t. Nova Acta Ksl. Leop.-Carol. Deut, Akad. Nat. $47: 145,190$.

—_. 1894. Plıys. Morph. Nied. Organismen Q: 3.

\section{Chapter VIII}

\section{Hosts and Bibliography}

The fungr described in the previous chapters are widely distributed in nature and ubiquitous in host range. As noted before, they occur in fungi, freshwater and marine algae, liverworts, mosses, gymnosperms, angiosperms, infusoria, rotifers, nematodes, insects, and erustaceans. With the view of expediting reference to these fungi and their hosts, a complete host index and bibliography is herewith presented. The hosts are listed in solid type and their parasites in italics. The arrangement of the divisions, orders, and families of hosts does not follow any particular system of elassifieation. Systematists in particular fields will doubtless object to and take issue with the present arrangement, hut the primary object of this index is not a elassifieation of algae, fungi, higher plants, and animals. In order to aroid confusion through personal interpretation of synonomy, the hosts as well as their parasites are listed in the same manner as reported by the various workers. The exaet identity of many of the early described parasites is doubtful. The early workers were not very specifie in their reports and descriptions, so that it is not certain which species of Olpidiopsis, Myzocylium, Lagenidium, etc., Nägeli, Cienkowski, Stein, Pringsheim. Reinsch and others, for example, referred to. Sucl, parasites have, nevertheless, been listed with question marks in the index with the view of hringing them to the notice of research workers.

\section{THALLOPHYTA}

\section{FUNGI}

\section{Olpirliecere}

Sphaerita endogena

Olpidium sphneritae

Dangeard, 1889. Le 13ot. 1:51.

Prsudolpidium Splucreriture (Dang.)

Fischer, 1892. Rabenhorst's Fryt'fl. $1,4: 36$.

Olpidiopsis Sphueritu (Dang.)

Schroeter, 1897. Engler und Prantl. Die Nat. Pflanzf. I, $1:$ : 6 .
Rozella septigena

olpirliopsis irreguluris (?)

Constantineanu, 1901. Rev. Gen. Bot. 13:376.

\section{Sripoleguinceres}

Aehlya sjo.

Itoronime polycystis

Dangreard, 1890. Le Bot. $2: 145$.

Hartog, 1890. Rept. 6th Meeting Brit. Assn. Adv. Sci. 1890: 872.

Petersen, 1909. Bot. Tidsskr. 29: 126. 1910, Ann. Mycol. 8:5.57.

Cook and Nicholson, 1933. Ann. Bot. 47:851.

Sparrow, 193?. Mycologia 24: 273. 1933, Mhid. $25: 515$. 1936, Jour. I inn. Soc. I ondon, Bat. $50: 425$.

Rozella simulüs

Maurizio, 1895. Jahrh. Nat. Gesell. Graübundens 38: 9.

Rozellopsis simulaws (Fischer)

Karling, 19.1?. A mer. Jour. Bot. $39: 33$, 194:2, Mycologia $34: 20 \%$.

Olpidiopsis incressuta

Sorokin, 1883. Arcli. Bot. Nord France 2: ?9. 1889 , Rev. Mycol. $11: 81$.

Psendelpirlium incressistu

Sparrow, 1933. Mycologia $25: 515$.

Olpidiopsis Suproleyuin"

Petersen, 1909. Bot. Tilsskr. 29 : 404. 1910, Ann. Mỵcol. $8: 539$.

Sparrow, 1932. Mycologia 24: 270. 1933, Ibirl. 25:515.

Gilman and Archer, 19:9. Iowa Jour. Sei, 3 : 299.

Olpidiopsis fusiformis.

Comu, 1872. Ann. Sci. Nat. 5 ser. 15: 147.

Sorokin, 1883. Arch. Bot. Nord France 2: 27. 1889, Rev. Mycol. $11: 83$.

Pseurlolpidium fusiforms

Sparrow, 1932. Uycologia 21: 272. 1936, Jour. I.inn. Sue. I ondon, Bot. 50 : 425 .

Olpirliopsis inder.

Cornu, 187:, l.c. p. 145.

Achlya americana

Worominu (?) asterina

Toknnaga, 1933. 'Trans. Saplyoro Nat. Hist. Soc. 13: 96.

Achlya colorata

Olpidiopsis zarions

Shanor, 1940. Jour. Elisha Mitehell Sei. Soc. 56: 171. 
Achlya de Harỵuat

II coranina pulyeystios

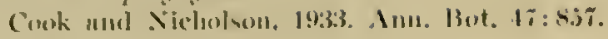

Achlya llagrelluta

livatlur vimuleros

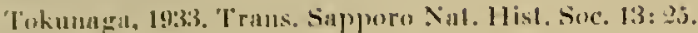

liosellopsis simulans (Fischer)

kinrling. 1913. Am. dour. 130t. 23!: 333. 1942, Ilyenlogia 3t: $30 \%$.

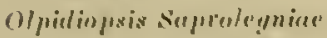

Coker. 1923. 'The Sajprolegniaceac, j. 1 s1.

Olpivinpsis fuxiformis (弓)

Cienkuwski, 1s5j. Bot. Zeit. 13:s01.

Oprieliopusis minor

Matllews, I935. Jour. Elisha Mitchell Sei. Soc. $51: 310$.

l'seudolpidium fuxiforme

Fiscler, 1s93. Rahenhorst's kiryt'tl. I, $1: 36$.

Mattlews, 193j. Anur. Flisha Mitchell Sei. Soc, $51: 310$.

Silvada, 191?. Spree. I3ull. Agr. Exp. Sta. Formosa $111: 199$.

Tokultaga, 1!33. 'T"rans. Sapporo Nall. 11 ist. 13: ?1.

Olpidiupris spinose

Tokunatgis. 19:33. 1.c.. p. 25.

Psoudelpirlium slalletum

Sawada. 191:. Spec, 13ull. Agr. Exp. Sta. Formosa, $111:$ :0. 1912, Jbid. 19.

Olpriliopsis zuriun.

Shanor. 1939. Jour. Elisha Mitehell Sei. Soc. 5j: 172, 14.5. 1910. Ibid. sti:171.

Olpidiopsis . I chlyere

MeLarty, 1911. 13ull. 'Torrey 13ot. Cluh 68: 62, 75.

Achlya tlagellata var. yeyoemsis

l'sentolpielium fusiforme

Tokunaga, 1933. Trans. Nat. IIist. Soc. 13:?1.

Achlya imperfecta

Olpidioposis suprolegniue

Coker, 19:3. The Sitprolegniaceae, p. 181.

Olpilliopsix fusifurmis

Shanor, 1940. Jour. Elisha Mitehell Sei. Soc. 56:171.

Achlya klelisiana

Olpidiopsis fuxiformis

Slanor, 1940. Juur. likislat Sci. Soc. j6: 171.

Achlya leucosperma

Olpidiopsis funifurmis

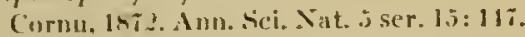

Perulolpillum fusiforme

Finclier, Ing I. Kalbenhorst"s Krypt" fl. J, 1: 36.

Olpidiopsis minor

Fischer, 1s9\&, l.c.. p.339.

Achlya polyandra

11 oromina polycyelis

Cormu, 14iz. Ann. Scí. Nat. s ser. 15: 17\%.

Rozolles simulans

Fiselwer. 1s4?. Jahrh. Wiss. Bot. 13: 321 .

Rozellopsis simuleus (l*ischer)

Karling. 1912. Amer. Jour. Bot. 29: 33. 1912, Mycologia $31: 20 \%$.

Olpridinpisis fusiformis

Fischer, 1642. Jalırh. Wiss. Bot. 13: 36 t.

Psoudolpilium fuxiforme

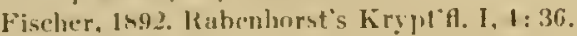

Olpidiopsis minor

Fiscluer, 1s92, l.c.. p. 39.
Arlalyn proliferoides

Olpieliopsis zarimos

Shanur, 1940. Jour. Vilisha Mitchell Sci. Soc. $56: 17$.

Achlya raceonosia

II oronina pulyeystis

Cormu, 187. Ann. Sci. Nat. sorr. 15: 177.

Sorokin, 1883. Areh. Wot. Nord l'ratuer 2: 39. 1889, Rev. Mreol. 11: 139.

linsella simuluus

Jisclier, 1462. Juhrl, Wiss. 13ot, 13:321.

Minden, 1911. Krvut'H. Mark 13raudenburg 5: 271.

liosellopsis simulans (Fischer)

Kiırling, 1912. Amer. Jour. J3ot. 99: 33. 191:, Mycologia 3t: 207 .

Olpidiopsis incressule

Cornu, 1852, l.e., p. 116.

Pseudolpidium inrrussetum

Fischer, 1802. Rabenhorst, Kryjt'fl. I, 1:37.

Petersen, 1910. Anm. M! ycol. 8:5+1.

Olprediopsis fusiformis

Cormu, 187:. Anu. Sci. Nat. 5 ser. 15: 117.

Fischer, 188:. Jahrb. Wiss. 13ot, 13: 364 .

Shanor, 19»0. Jour. Elisha Mitchell Sci. Soc. 56: 171.

Psemdolpidium fusiforme

Fischer, 1892. Rabeuhorit's Krypt'fl. I, I: 36.

lokunaga, 1933. Trans. Sapporo Nat. Ilist. Suc. 13:21.

Olpirliopsis minor

Fischer, 1892. Rabenlorst's Krypt'fl. I, 4: 39.

Cejp. 1931. Zvlátšt otisk z časop. Veda prírodni roe. 35: 220.

Olpieliupsis zarians

Shanor, 1940, l.c., 11. 171.

Aphanomyces cladogamous

Olpioliopsis atphenomycis

Whiften, 1942. Anure. .J our. Bot. 29: 609.

Aphanomyces laevis

Psendolpidium dphumomyris

13utler, 1907. Neru. Dept. Agr. India 1, no. 5: 132.

Sydow and Butler, 1907. Ann. Myeol, $5,18.5$.

Butler and l3ishy, 1931. 'l'he fungi of India.

Olpricliopisis luxuriens:

Barrett, 1912. Ann. 13ot. 26: 231 .

Shanor, 1939. Junr. Elisha Mitehell Sci. Soc. 55: 190. l!) 1 , IJil. .j(i: 170 .

Aphanomyces sp.

Olpridiojis is alphommysis

Cormu, 1872. Ann. Sci. Nat. 5 ser. 15: 118.

Petersin, 1903. Jour. (le Bot, 17: 211. 1909, 13ot. 'Tidsstir. 29: 104. 1910, Anu. Mỵcol. s: 339.

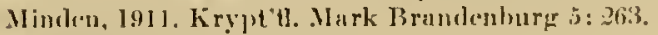

Pacuchalpidium a phanomyris

Fischer, 1892. Kahenhorst's Krypt tl, I, t: 37.

Iso:achlya anisospora

Olpirlinpsis Soprolegnin

Shanor, 1940. Jour. Elisha Mitchell Sei. Soc. 56: 172.

Olpidiopseis incrersselate. Slatuor. 1940. l.e.

Isomelilya creent ricin

()pridiopais suprolegnin

Sluanor, 1940. Jour. Elisha .Mitchull Sici. Soc. 56: 172.

Isisachlya moispora

Olpirliopsisis suproleynime

Slanor, 1940. Jour. Holisha llitchell Sci. Soe. $56: 172$.

Olpieliopsis ineressuta. Slatonr, 1910. I.e. 
Saprolegnia spl.

Woronina polycystis

Maurizio, i 895. Jahrb. N゙at. Gesell. Graiibundens $38: 9$.

Cook and Nicholson, 1933. Ann. Bot. 47: 857 .

Hornuiur polycystis forma sculcriformis

Petersen, 1909. Bot. Tidsskr. 29: 4:66. 1910, Ann. Mycol. 8: 557 .

Olpidiopsis Suprolegniae

Cornu, 187\%. Ann. Sci. Nat. s̀ ser. 15: 145.

Pringsheim, 1860. Jahrb. Wiss. But, 2: 205.

Reinseh, 1878. I ahrb. Wiss. Bot. 11:304.

Fisher, 1880. Bot. Zeit. 3s: 689.

Surokin, 1883. Arch. 13ot. Ford France 2: 27. 1859, Rev. Mrcol. It: 84 .

Dangeard, 1890. Ie Bot. 2: 83.

Constantineanu, 1901. Rev. Gen. 13ot. 13: $37 \%$.

Petersen, 1909. Bot. 'Iidsiskr. 29: 40. 1910, Ann. II ycol. 8: 539.

Barrett, 19 :2. Ann. 13ot. $26: 222$.

Schwarze, 1922. Mycolugia 14: 15:.

Varitchak, 1931. C. R. Acad. Sci. Paris 19:371.

Maneval, 1937. Eniv. Missururi Studies 12, no. $3: 52$.

Couch, 1941. Amer. Tour. Bot. 28: 706, 707.

Wolf, F. T., and F. A. Wolf, 194t. Iloydia $4: 370$.

Diplophysa suprolegnine

Schroeter, 1886. Cohn's Krypt'fl. Schlesiens 3:195.

Olpinliopsis irreguluris

Constantineanu, 1901. Rev. Gen. Bot. 13: 373.

Sparrow. 1931. Dansk. Bot. Ark. s:1.j.

Pupulolpilium fusiforme

Sparrow, 193\%. Mycologia $24: 272$.

Psudolpidium Saproleguine

Ce.jp, 1934, l.c. p. 2:26.

Saprolegnia asterophora

Psorulolpiclium sumpreleyniue

Fischer, 189-2. Rabenhorst's Krypt'fl. I, 4:35.

Saprolegnia delica

Olpialiopsix suproleyniure

Shanor, 1910. Jour. Elisha Mitchell Sci. Soc. $50: 170$.

Olpidiopsis ineressutetre

Shanor, 1940, I.c., p. 170.

Sayrolegnia diclina

Olpieliopsis supmoleyuiue

Sluanor, 1940, l.c., p. 170.

Olpidiopsis ineressuta

Shanor, 1910, l.c.

Saprolegnia dioica

Olpilliopsis erhiunte

Petersen, 1909. But. 'Tirlsskr. 29: 405. 1910, Ann, II r.col, $8: 540$.

Saprolegnia ferax

Horominn pulyeystis

Cook and Nicholson, 1933. Ann. Bot. 47: 857.

Chytrilium siaprolegniue

Braun, 1855a. Ber. Kgl. Prewss. Akad. Wiss. 1855: 3s4. 165.5b, Abl. K gl. Akad. Wiss. Berlin, 18.55: 61 .

Olpidium Suprolegniue

Braun, [855h, 1.c., ]. 7.5.

Olpidiopsis Seproleynice

Harvey, t927. Trans. Wisc. Acad. Sei. Arts, Letters 23: 5.5t. 1943, Jour. Wlisha Mitchell Sci. Soc. 58: 39.

Shanor, 1940. 1biel. 56: 170.

Olpuliopsis Sinprolegnios var. luezis

Coker, 1933. 'The Saprolegniacrae, p. t85.
Olpidiopsis zeaus

Barrett, 1912. Ann. Bot. 26: 231.

Olpidiopsis inerassata

Shanor, 1940. Jour. Elisha Mitchell Sci. Soc. 56: 170.

Saprolegnia ligpogyna

Olpidiopsis mujor

Maurizio, 189j. Jahrb. Nat. Gesell. Graubündens $39: 15$.

Saprolegnia lactea

Olpirliopris Suproleynice (?)

Pringsheim, 1860. Jahrb. Wiss. Bot. 2: 205.

Saprolegnia littoralis

Olpidiopsis Suprolegniate

Shanor, 1940. dour. Elisha Mitchell Sci. Soc. $56: 170$.

Olpitiopsis inerassuta

Shanor, 19 t0, l.c.

Saprolegnia mixta

Otpirliopsis Suproleguine

Diehl, 1935. Centralbl. Bakt. Parasitk. II, 92: 2:29.

Shanor, 1940. Jour. Elisha Hitchell Sci. Soc. $56: 170$.

Olpurlinpsis incerassuta

Shanor, 1910, l.c.

Saprolegnia monilifera

Olpidiopsis Suprolegnine

Tokunaga, 1933. Trans. Sappora Nat. Hist. Soc. 13: :24.

Saprolegnia monoica

Joromina polycystis

Dangeard, is90. I.e Bot. 2: 145.

Fischer, 189:. Rabenhorst's Krypt'tl. I, 4:66.

Rozella septiyenu. (Not R. septiyeua Coruu)

Fischer, 1883. Jahrb. W'iss. Bot. 13: 321 .

Rozellopsis septigpull (Fischer)

Karling, 19.2. Amer. four. 13ot. :29: 33. 194:, Mycologia $3 \mathrm{t}: 206$.

Olpicliopsis echimutu

Petersen, 1909. 130t. 'Tidssk. 29: 105. 1910, Ann. II ycol. $8: 540$.

Olpidiopsis Suproleguiue

Graff, 19:8. Mycologia $20: 159$.

Shanor, 1910. Jour. Ehsha Mitchell Sci. Soc. 56 : 170.

Olpidiopsis Saprolegnief var. late is

Coker, 1933. The Saprolegniaceae, 1) 18.5.

Psendolpirium Soproleguiate (")

Fischer (pro parte), is9:. Rabenhorst's Krypt'fl. I, 4: 35 .

Olpidiopsis incressate

Shanor, 1940. Jour. Elisha Mitchell Sci. Soc. 56: 170.

Saprolegnia spiralis

Horonimu jolycystis

Cornu, 1872. Aun. Sci. Nat. 5 ser. 15:17\%.

Saprolegnia thuretii

IVorominu polyeystis

Fischer, 189\%. Rabenhorst's Krypt fl. I, 1: 66.

Rozellu septiyenu. (Not R. septiglua Cormu)

Fischer, 188: dahrh. Wiss. Bot. 13:3?1.

Rosellopsis septigent" (Fischer)

Karling, 1942. Amer. Jour. Bot. 29: 33. 19:2, MycoJogia $31: 206$.

Olpiliopsis Suprolesmine

Fischer, 189\%, l.c.. 11. 38.

Minden, 1911. Krypt'f. Mark Brandenburg 5: 263.

Davis, 1914. Trans. Wise. Sci. Arts, Letters 17, 2: 818. 
Psendolprilinm suproblegnim (")

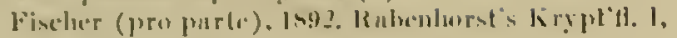
$1: 3.5$.

Tokumaga, J93:3, Tram, Sappura Nal. Ilint. Sice. 13: 2?.?.

() Milliopisis mujer

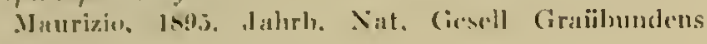
3.5: 1.5.

ryllinrerse

I'yllimm - Th,

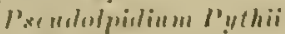

Mimlen, 1911. Kryjl’t. Mark. Brandenhury .j: 269.

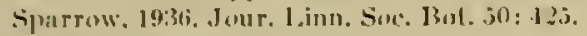

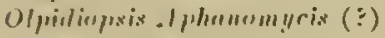

Dangeทrel, 1890). 1.e 13ot. 2: 63.3.

ly-thimu diclyompormm

Pylhidlla zormulis

Conch. 193.3. Myoulugia 2i: 160.

Pyllum gratcilte

"uthiellu reeruntios

Couch, 19:3.5, l.e.

Prthium inlermedium

Plonlpirlium inflatum

Butler, 1907. Yem. Dejet. Agr. India 1, mo. 5: 1:6, 127.

Ruallopxis influlu (Butler)

Karling. 1912. Aner. Jour. Jot. $29: 31.194 \%$, Jyeologria :34: 205 .

Psurululpirlinm P!ythii

Bulle.5, 1907, 1.c.. J. 137.

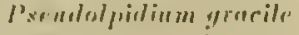

Butler, 1907, l.c., p. 129.

Dlpielieppisis curciappinose

I1"hiffern, 1942. Amer. Juur. 13ot. 29: (i]0.

()lpioliopsesis lerezispinosul

W'lsiffen, 1912. l.c.. P. 610.

l'y thium monespermum

Parterlpulimm P'ythii

13utler. 190\%, 1.c., ]. 137.

Pythium uryzate

Pserdulpilimur l'ythii

'Jukunaga. 1933. 'I'rans. Sapporo Xat. llint. Soc. 13: :2.2.

l’ythium roslratum

I'xrindeslpirlium Pythii

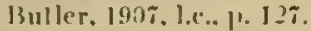

Promelolpielium yrurilo

11 hiffen, 1912, l.c.. p. 610 .

jylliurn Lorulomem

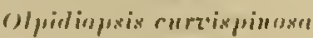

W"liff('). 1!) 2, l.c.. ]). 1i10.

Pythium sexams

Peruderlpridirm Pythii

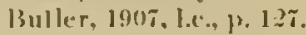

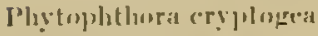

jerolpisliem -p.

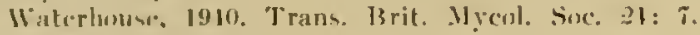
1912,1 hid. 2: : 317 .

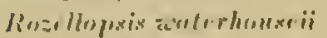

Karling. 1912. Amur. Jumr. J3ut, 39: 34. 1912, N!ecologia 31 : 2016.

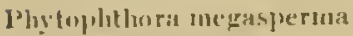

Pireslpidium sp.

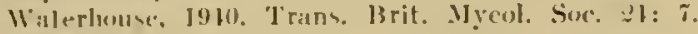
$1912, \mid l$ irl, $25: 31$;

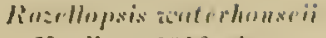

Kurling, 191?. Imer. Jour. 13ot. 39): 34, 191:, .19(2)logia 31: :060.

Anemreerus

l'iloholus spl.

11 ioromines sp.

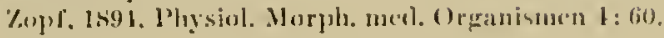

\section{A.CiAk}

MYXOHICFAE

Oscilleterineener

I.yugloya aestuarii

lirstimularier undesser

1):1ngeurd, 1891. J,e 13ot. 2: 96.

Tolyputhrix s]3.

\section{Sirytonemureren}

Restienlarin besedlei

Fritsch, 1903. Anu. Bot. 17: 6.5.1.

R. nodisule (?)

Fritsch, 1903, J.e.. ]3.6.50.

\section{HETEROKON"AE}

Tribumemurear

'ribonema bombycinum

Olpiclinpris sorohinii

De Wildeman, 1890. Ann. Soc. Bely. Micro. 14: 2.2.

$$
\text { reyletemonadereses" }
$$

Cryptomonas wrata

Sphaterila radiela

Dangeard, 1894). I,e Jout. 3: 51.

Finglenas sp).

Einglenereare

Myzocytium sp. (?)

Sparrow, 1936. Juur. I inn. Suc. 1.omton Bot. 50: 463.

Euglend caulata

Psudospheritu Enelemer

Jitchell, 19-s'. Trans. Amer. Nicro. Soc. 17 : 30.

Englena polymorpha

P'sendospherrila Englener

Dangeard, 1895. I.e J3ut. 4: 213. 1933, /l,ill. 25: 36.

Jimglena sanguinea

l'surlosphar rita linglenar" (?)

Nigler, 1911. Areh. Protistk. 23: 263.

billglena viridis

Psoudosphererilu Englones

Dangeard, 189.5. l.e 13ot. 1: 2133, 1933. /lidl. 25: 36.

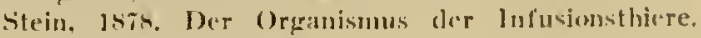
Alit. 111, pl. 20, lig. :21.

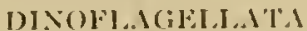

$$
\text { Peristiniereare }
$$

(ilemolinium cinctum

Olpiolinm Gileneshinienum

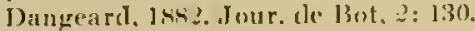

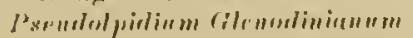

Jischer, 189:. Rabenhorsl is krypl'11. 1, l: 36.

\section{1) J.1'10MS}

Bucillerienesen

Amphora swalis

Inepenidinm ruerous

Scherffel, 192.5. Ar'lo. l'rulislk. i2: 20. 
Cocconena lanceolatum

Ectrogrlla bacillariacearum

Gill, 1893. Jonr. Roy. Miero. Soc. 1893: 1.

Lagenidium enecans

Scherffel, 19:5, l.c., 1). 20 .

Cyclotella kiitzingiana

Lryenirlium Cyclotellae

Scherffel, 19:5, l.c., p. 18.

Cymatopleura solea

Lngenidium enecans

Selierftel, $19 \supseteq 5$, I.c., p. 20.

Cymbella cymhiformis var. parva

Layenidium brachyostommm

Scherffel, 19:5, l.c., p. 21.

Crmbella gastroides

A phanomycopsis bacillariacearum

Scherffel, 19:25, l.c., p. 14.

Laypnidium enecons.

Scherffel, 19:5. l.c., p. 20.

Epithenia turgida

Aphanomyropsis bacillariacfarum

Scherffel, 19:5, l.c., p. 14.

Gomphonema s]).

Ectrosella bacillariacearm

Zopf, 1881. Nova Acta K'sl. Leop.-Carol. Deut. Akad. Nat. $4 \pi: 17 \%$.

Scluerffel, 1925, l.c., p. 6.

Domjan, 1935. Folio Cryptoganı. 2: 9.

Olpirlinm gilli

De Wildenan, 1896. Ann. Soc. Belge Micro. 20: $\$ 1$.

Gomphonema constrictum

Lugenidium brechyostomum

Scherffel, $19 \geqslant 5$, l.c., p. 21 .

Gomplionema micropus

Ertrogella Gomphonematis

Scherffel, 1925, l.c., p. 9.

I.auderia borealis

Olpirlium Lauderiue

Gran, 1900. Nyt. Mag. Nat. 38: 123.

Eurychasma Laideriu"

Petersen, 1905. Overs. Kigl. Dansk. Vids. Selsk. Forh. $5: 469$.

licmophora sip.

Ertroyella Licmophorar

Scherffel, 19:5. A reh. Protistk. 52: 10.

Eetrigella performs

Sparrow, 1934. Dansk. Bot. Ark. 8, no. 6: 19.

Licmophora abbreviata

Ectroyella perforans

Sparrow, 1936. Biol. 13ull. 70: 239.

Licmorplora Lỹnglỵei

Ectrogella perforans

Petersen, 1905. Overs. Kgl. Dansk. Vids. Selk. Forh. s: 1606 .

Mericlion circulare

Eretrugella barillariarearum

Scherffel, 19:25. Arch. Protistk. 5: : 6.

Dom,jan, 1935. Folio Cryptogam. Q: 9.

Naviculal sps.

Iphunomycopsis bacillariacearm

'lokumaga, 1931. 'l'rans. Sapporo Nat. Hist. Soc. 13: 237.
Nitzschia linearis

Lagenidium brachyostomum

Scherffel. 19:5, l.c., ]) 21.

Nitzschia sigmoidea

Ectrogella bacillariacearum

Gill, 1903. Jour. Roy. Nlicro. Soc. 1893: 1.

Aphanomycopsis barilariacearum

Scherffel, 1925, l.c., p. 14.

Pinnularia sp.

Eetrogella breillariacenrum

Zopf, 1884. Nova Acta Ksl. Leop.-Carol. Deut. Akad.

Nat. 47: 177.

Sclierffel, 1925. Arch. Protistk. 59: 6.

Sparrow, 1933. Nycologia $95: 531$.

Domjan, 1935. Folio Cryptogam. 2: 9.

Ectrogella monostoma

Sparrow, 1933, l.c., p. 531.

Apharomycopsis harillariacearum

Sparrow, 1933, l.c., p. 530.

Layenidium sp.

Scherffel, 19:5, 1.c., p. 23.

Pinnularia viridis

A phanom!copsis hacillariacearm

Scherffel, 19:5, l.c., p. 14.

Layeridium enecans

Scherffel, 1925, l.c.. p. 20 .

Pleurosigma angulatum

Ectrogella bacillariucenum (?)

Van Heurck, 1899. Traité des Diatomees. Anvers.

Pleurosigna attenuatum

Eetrogella bacilluriacearum

Gill, 1893. Jour. Roy. Micro. Soc. 1893: 1.

Stauroneis phoenocentron

Layenidium enecums

Scherffel, 19.25, l.c., p. 20.

Striatclla unipunctata

Ectrogella perforcus:

Sparrow, 1936. Biol. Bull. 70: 239.

Surirella sp.

Aphanomycopsis bacillariacearm

Tokunaga, 193t. 'Trans. Sapporo Nat. Hist. Soc. 13: 237.

Synedra sp.

Ectrogella barillariacen'um

Zopf, 1884. Nova Acta Ksl. Leop.-Carol. Deut. Akad. Nat. 47: 17\%.

Gill, 1893. Jour. Roy. Micro. Soc. 1893: 1.

Olpielium yilli

De Wildeman, 1892. Ann. Soc. Bel gre Micro, 20: 41 .

Synedra lumularis

Ectragella bacillariacearum

Zopf, 1884. Nova Acta Kisl. Leop.-Carol. Dent. Akad. Nat. $47: 17 \%$.

Synedra ulna

Ectroyplla perforans

Petersen, 1905. Overs, Kul. Dansk. Vids. Selsk. Forlı. $5: 466$.

Eetrogella bacillariacerermm

Scherffel, 192.5. Arch. Protistk. 52: 6.

Domjan, 1935. Folio Cryptogain. : 9.

Eetrogella monostome

Scherffel, 19:5, l.c.. 1). 


\section{CIII.OROTIIVClis:}

Chlomyelomonadaroue

Chlamelomomas alhoriridis

P'seculasplaneritur Einglemere (?)

stein. 1sit. Der (Organismus der lufusionsthicre. Abt. 111, 11. 11, fig. VI 1-I1.

Clalamyorlomomos pulviscolus

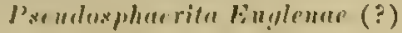

stein, 1אis, l.c.. p]. 1.5, tiy. 36.

\section{Xy!memucrine}

Misocarpus $\leq p$.

Olpialiopsis schenkiana

Zopf. 1sist. Nova Acta Ksl. leopr.Carol. Deut. Akad. Nat. 17: $16 \mathrm{~s}$.

liphophyse schenkinna

Schroeter, 1597. Engler und Prantl, Die Nat. Pflany'f. 1. $1: 8.5$.

Pso udolpiolinpsis schentiunn

Minden, 1911. Krypt't. Mark Brandenhurg 5: 257.

liphophysan elliptira

Sclirocter, 1ssti. Coln's Krypt fl. Schlesiens 3: 196.

Olpieliopsis miplisu

F"ischer. 1s9?. Rabenhorst's Krypt"fl. I, 1: 11.

Jusulolpioliopsis elliptica

Minden, 1911. Krypt $f$. Mark 13 randenhurg $5: 260$.

Olpicliopsis appendirulutu

I). Wilkeman, 189j. Ia Notarisia I0:34. 1896, Ann.

Suc. Bcelge .ITicro. $\geq 0: \geq 9$

l'se adolpioliopsis nplondirulata

Minden. 1911. Krypt fl. Mark Brandenburg 5: 259 .

Lugrnidium rabenhoretii

\%opf. 1Kis. Verh. Bot. Ver. Pros. Brandenbury 90: 7. Ist. Nova Acta hisl. Leop.-Carol. Deut. Akad.

Vint. 17: 11.5

1/ yะreytium prolifurum

\%opf. 1stit. l.e. p. 159.

Scherffel, 190?. Now Kïzl, 1: (109). 1926, Arch, Protitak. $51: \geq 15$.

17. irregulure

Ce.jp. 1935. 13ull. Int. I'Acud. Sci. 13aheme 1935: \%.

Mesocarpus pleurocarjus

Vyzoncytium proliferum

Schroeter, Iswor. Cohn's Krypt'fl. Schlesiens 3: 227.

Mongentia sp.

()lpirlioprsis xchenkinna

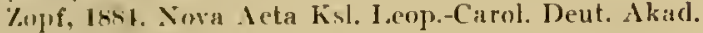
Dat. 17: Iris.

Leupnidlum robenhorslii

\%ipf, 1sist. l.c.. 1) 145.

Valkanex, 1931. Areh. Protistk. 73: 365.

Jyzarytium proliferum

sichent. 1sish. ther das Vurkommen Contractiler

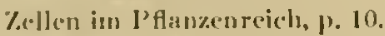

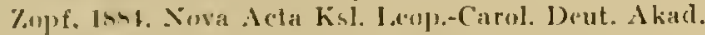
ㄴa1. 17: 1.59 .

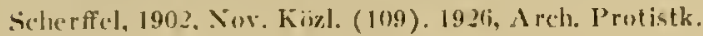
.j: : 21.5 .

Petersclt. 1909, 130\}. 'Tilskr. 29: 102. 1910, Sun. IIs:col. s: 5.3\%.

Minden, 1911. Krypt"fl. Mark I3ramlenhurg s: I:31.

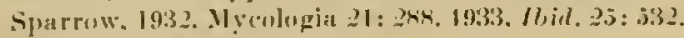

Domjun, 193\%. Folio Crypt. 2: s1.

V. irregulure

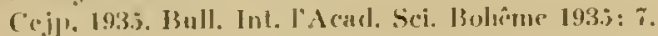

Spirogyrar sp.

Olpiblinpsis sohentiuna

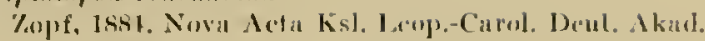
Nitl. 17: 16s.

1). Wildeman, 1890. Ant. Sixe. Belge Micro, 11: 21. 1891, I3ull. Soce. Roy. 130t. 13(.lg. 30: 173. I896, Am,

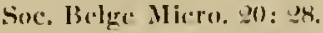

Constantineanu, 1901. Rev. Cien. 13ot. 13: 33i.j.

Butler, 1907. Ncm. Depl. Agr. India 1, um. i: 135.

13uller and 13isby, 1931. Fungi of Indiat.

Scherflel, 19:5. Areh. Prol intk. 52: 1:3\%.

Irocystidium parasiticnm

lisish, 18st. Sitzb. Phys.-Iled. Soc. Frlangen 16: (00.

Olpidiopsis purasilica (Fiseh.)

Fisclier, 189?. Habenhorst Krypt'fl. I, 1: 10.

Diplophysa schenlikun ('/u]if)

Sceluocter, 1897. Engler und Prantl, Dic Nat. Pflanzen $f$. I, I: 85.

Prendolpidiopsis schwntiuna (\%opef)

Minden, 1911. Krypt'tl. Mark 13randenhurge 5: 2.5\%.

'Jokunaga, 1933. J'rans, Sapporo Nat. Hist. Soc. 13: 82.

P. preresitive (Fisch)

II inden, 1911, l.c., p. 叉\$s.

Olpidiopsis zopfii

De Wildeman, 1895. Ia Nutarisia 10:31. 1896, Ann. Soc. Belye Micro. $20: 25$.

Psoulolpriliopsis zoppii (de Wildemitn)

Minden, 1911. Krypt'fl. Mark Brandenbury 5: 259.

Olpidiopsis fibrillosn

D) Wildeman, 1895. I a Notarisia 10: 3.4. 1896. Ann. Soc. Belge Micro. $20: 27$.

l'sendolpidiopsis fibrillost

Minden, 1911, Krypt'fl. Mark Brandenluty 5: :39.

Lagnielium rabenhorstii

7ouf, 1878. Verh. Bot. Ver. Pros. Brandenbury 30: 79. 1879. Hedwigia 18: 94. 1881, Nova Acta lisl. I.eop.-Carol. Deut. Akirl. Nat. $17: 11.3$.

De Wildeman, 1891. Bull. Sore. Roy:. But. Belge 30: 137. 1893, Amm. Soc. 13elge Micro, 17: 45. 189.; Mem. Soc. Belge Micro, 19: 98.

Constantineanu, 1901. Rev. Gen. Bot, 13: 3 \%9.

Atkinson, 1909. Ann. Mycol. $7:-150$.

Valkanov, 1931. Arch. Prolistk. 73: 36.5.

Scherffel, 19:ti. Hid. 54: 11 is, j10.

Sparruw, 1932. Mycolagia 21: 289.

Ce.j], 1935. 13ull. Int. l"Acad. Sci. Bohême 193.5: 7.

Domjan, 193.5. Folio Cryptogam. ㅇ: 31.

Cook, 1932. New 1'yytol. 31: 112. 1933, Giamorgan County Nat. Hist. 1: 214. 1935, Arch. Protistk. xi: 63 .

Lngenidlinm enlophytum

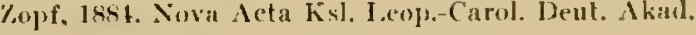
Nat. $47: 1.51$.

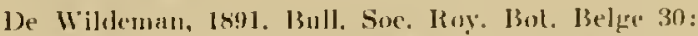
13к. 1893, Ann. Sme. 13. lge Miero. 17: 10, 16. I89.j, Jlen. Sise. Belge Jiroro, 19: 100.

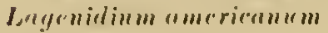

Atkinson, 190!) 13ot. (in\%. 18: 331.

Pythium antophylum

P'ringshein, Isiss, Jalirl,. Wiss. Bot. 1: $28 \pi, 30 \pi$.

Langrnilinm yrocils

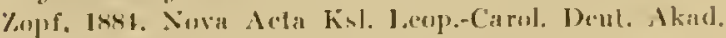
Sat.

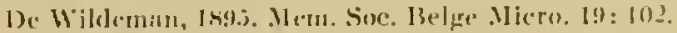

Conk, 19:32. Xiew 1'hytol. 31: 140. 1935, A reh. P'rotiatl. xis: in. 
Lagenidium papillosum

Cocconi, 1894. Mem. R. Accad. Sci. Inst. Bologna $4: 36 ?$.

Myzocytium proliferum

Schenk, 1858, Über das Vorkommen Contractiler Zellen im Pflanzenreich, p. 10. 1858, Verh. Phys.-Med. Gesell. 8: XXVIJ. 1859, /biul, 9: a7.

Cornu, 1869. 13ull. Soc. Bot. France $16: 222$.

Zopf, 1884. Nova Acta Kisl. Leop.-Carol Deut. Akad. Nat. $17: 159$.

De Wildenan, 1893. Ann. Soc. Belge Micro. 17: 53. 1895, Ibid. 19:68.

Constantineanu, 1901. Rev. Gen. I3ot. 13: 377.

Scherffel, 19:6. Arch. Protistk. 54: 245, 511.

Skvortzow, 19:27. Ilid. $57: 206$.

Valkanov, 1931. Hid. 73: 365.

Tokunaga, 1934. Trans. Sajpjoro Nat. Hist. Soc. 13: Q28.

Cej]", 1935. Bull. Int. I'Acad. Sci. Bohême 1935: 6.

Pythium globosum

Schenk, 1858. Verl. Physs.--IIed. Gesell. 9: 27.

Pythium globosum

Walz, 1870 (pro parte). Bot. Zeit. $95: 556$.

Lagonirlium globosum

Lindstedt, 1872. Synopsis d. Sajroleg., ]. 54.

Spirogyra affinis

II yzocytium proliferum

Chaudhuri, 1931. Arch. Protistk. 75: 17\%.

Mundkur, I938. Fungi of India. Suppl. J.

Spirogyra calospora

Lregenidium americamm

Atkinson, 1909. Bot. Gaz. 48: 334.

Spirogyra grevilleana

Lagenidium grarile

De Wildeman, 1895. Mem. Suc. Belge Micro. 19: 10?.

Spirogyra insignis

Lagenirlium umericanum

- Atkinson, 1909. Bot. Gaz. 48: 334.

Spirogyra jurgensis

II yzocytium proliferum

Tokunaga, 1931. Trans. Sapjoro Nat. Hist. Suc. 13: 929.

Spirogyra milabilis

Lreunidimm rebenhorstii

Domjan, 1935. Folio Cry]t. 2: 31.

Spirogyra orthospira

Lagenialinm rabenhorstii

Gruff, 1928. Mycologia $20: 169$.

Spirogyra variams

Lagenislium ameriranam

Atkinson, 1909. Bot. Gaz. 48: 334 .

L. rabenhorstii

De Wildenatn, 1s91. Bull. Soc. Belge Micro. 16: 138.

Zỵgnema s]'.

Lnymidium robunhorstii

Dontaun, 193.). Folio Cryjt. 2: 31.

1y y=ocytium prolifrum

Schenk, 18iss. Clyer das Vorkommen Contracteler \%ellen im Pflanmenreich, P. 10.

\%opf, 188t. Nova Aeta Kol. I eevp.-Carol. Deut. Akad. Nat, 1\%: 159.

De Wildeman, 1895. Ann. Soc. Belge Micro. 19: rfi.

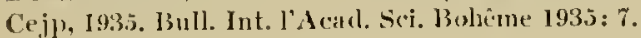

Pythium proliferum

Walz, 18\%0. Bot. Zeit. $28: 556$.

P!thinm globessm

Walz, l.c., ]. 556.

Zygnema cruciatum

My $y$ ocytium proliferum

Graff, 1928. Iycologia 20: 168.

Desmilacene

Arthrodesmus sp.

Birricium nuso

Sorokin, 1883. Arch. Bot. Nord France 2: 44. 1889, Rev. Myeul. 11 : 138.

Closterium sp.

Lagenidium Closterii

Petersen, 1910. Ann. Uycol. 8: 53\%.

Ceji), 1933. Bull. Int. iAcad. Bohême, I933: 7. 193ð, llid. p. 9.

Couch, 1935. Mycologia 27: 384.

Luypnidium intermedium

Ce.jp, 1935, l.c., p. 8.

De Wildeman, 1893. Ann. Soc. Belge Micro. 17: 54. 1895,1 bill. $19: 78$.

Myzocytium m"yustomum de Wildeman formu

Skvortzow, 192j. Arch. Protistk. 51: 431.

Myzacytium (Ancylistees) minrii

Skvortzow, $19: 5$, l.c., 1. 133.

Myzocytium froliferum

Ceip, 193?. 13ull. Int. l'A cad. Bohéme 193: 5 .

Closterium acerosum

.yzocytium prolifarum

Sparrow, 1932. Mycologia $24: 288$.

Closterium areolatum

My:ocytium megristomum

Berdan, 1935. Nycologia $30: 408$.

Closterium attenuatum

Myzocytium megrastomum

De Wildeman, 1893. Ann. Soc. Belge Micro. 17: 5.

Closterium didymotocum

I/ yzocytium lmoliferum

Reinsch, 1878. Jahrb. Wiss. Bot. $11: 300$.

Closterium chrenberyhii

Lagenidium intrimedium

De Wildeman, 1895. Ann. Soc. Belge Micro. 19: 96.

Closterium leiblinii

Myzocytium proliformm

Ce.jp, 193:. Bull. Int. l'Acad. Bohême 193?: 5.

Closterium ralfsii var hybridum

Lagenislium sncenluidios

Serbinow, 19:4t. Ia Defense des Plautes 1: 85.

Closterium striolatum

Lagrnidium C'losterii

De Wildeman, 1893. Ann. Soc. Belge Micro. 17: 12.

Myzocytium mernstumum

Berdan, 1938. Iýcologia 30: 108.

Cosmarium sp.

Mycocytium irreyulure

Ce.jl, 193.3. Bull. Int. l'Acad. Boh'me 1935: \%.

Cosmarium Butrytis

ly yzocytium forolifermm

Reinsch, 1878. Jahrh. Wiss. Bot. 11: 300. 
Comarium comalum

Yyacutium proliferum

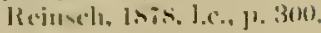

Cosmurium lÿramidatum

Jonpuirlinm ly,gmarem

sichultz-1)anzig, 19) 33. Sichr. r. Siissw-nud Mceresk. 11: 17!.

Cosmarium plamgana

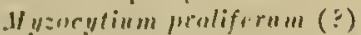

Roinsch. Ests. Inhrh. W"iss. But. 11 : 3000.

Duciklum chrenherghii

Witochytrilinm romensm

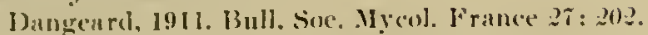

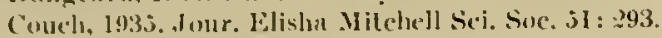

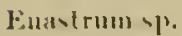

.11 y:ucytium froliformm

1)e Vileleman, 1s95. Ann. Sice. Belge Miero. 19: 7 .

Fuast rum homerosum

Lorepruidium eutophytum

Sclualtz-Danzig. 19:3. Schr. f. Siissw-und Meeresk. $11: 3$ ino.

Fuastrum ololongum

Lri!n nilinum sp.

De Mileleman, 18!5. Ann. Soc. Belge Micro. 19: 75.

Microusterias sp.

.1 yzorylium irregulore

Petersell, 1999. But. Tidsskr. 29: 403, 1910, Ann. Iỵcol. \&: 533 .

Jicroasterias mahabulenhwarensis var. walichii

Leenenirlium entophylum

Schultz-Danzig, 19:23. Sichr. f. Siissw:-und Meeresk. $11: 180$.

Dicroasterias rotatio

My:urutium prolifrrum

Reinseh, 18is. Jahrb. Wiss. Bot. 11:300.

Yy:orytium irregulure

Ceil), 1933. 33ull. Int. I'Acad. Sci. Bobrume 1933: S. 19:35, Ubill. j. $\mathrm{T}$.

Microasterian truncuta

Vyzurytiom irreyulure

C(.ji), 1935. /6idl. 13. i.

Peniun digritus

La!yrnillium s]r.

Siclurffel, 1936. Arch. I'rutistk, 51 : :216.

Pleourotatenium s]s.

.Vyzurytinm irreyulure

(c.i\}) 193.5, 1.c., 1. т.

Jleurutacnium ehrenherghii

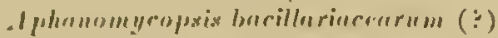

Went and II est, 1906. Trans. Ruy. I rish Acad. B, 33: $\approx$ i.

P'leurotanium trahecula

Lengenirlium infermedium

Cej], 1!13.5, J.1.. . . . .

spirotacnia sp.

. Iyzorylium mryuslomum

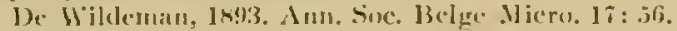

Spirotania condususulu

.11 yะuryfiltm s.

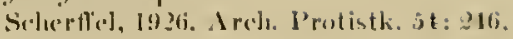

Staurastrum sp.

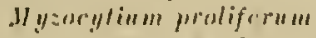

Selucerfel, 19:6, ].c., 1.,2 66.

\section{Chrietophersucerers}

Draparasalia glomerata

P'sundolpilium deformous

Serbiuw, 190i. Seripta Bot. Jhort. Lmpe. [nis.

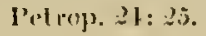

\section{Oedergeniucree}

(bedogronium s]).

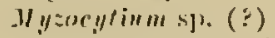

'Purwer, 186!. K'gl. Siensk. Folus. Akad. IJand. n.f. $25,110.5: 161$.

Langenislinm mbenhorestii

Pefersen, 190!). Bot. 'l'iklsk. 9: 400, 1910, Ann. My'col. 8: 536.

L. zanfii

De Wijdeman, I891. Bull. Soc. Brlge Micto. 16: 139.

Petcrsen, 1909. But. 'l'idiskr. 29: 101.

L. syurytiorum

Kleluhn, 189.2. Jahrh. Wiss. Bot. 24: 263.

L. marcheliurnum

De Wideman, 1897. Ann. Soc. Belge Micro. $21: 8$.

Couch, 193.5. Mycologia 27 : 38.1 .

L. Orelogonii

Scherffel, 190:?. Hedwigia 11: (10.5), 1935, Arch. Protistk. S2: 109.

Couch, 1935. Nyeologia $27: 386$.

Lanruilimm sp.

Cunch, 1935, l.c., ]. 385.

Olpieliopsis Ordoyonionem

Scherffel, 1925. Arch. Protistk. 5\%: 109.

Sparrow, 1933. Mycologia $25: 516$.

O. fusiformis var. Orelogoninrum

Sorokin, 1883. Arcli. 13ot. Xord France 2: 29. 18s9, Rev. Myeol. 11:89.

Olpridium Ordogyminrem (

De V'illeman, 1s9l. Ann. Soc. Belge Miero. 18: list.

Resticulacin Oedergonii

Skrortzow, 19:3. A reh. Protistk. 51 : 133.

Oedogonium boscii

Lenenilleme sunryfiorum

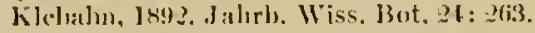

(helogumium crassusculum var. idiosporium

110 urouime polycystis

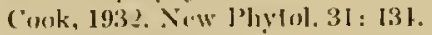

(). (logmium frankjinianum

lugenidium s]). (!)

sicherftel, 19:6. Areh. l'rotislk. sl: 216.

Gedogoniuns obsidiomale"

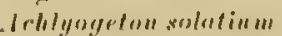

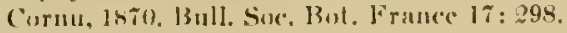

(kedogranium ortlompira

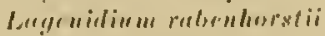

(iraff, 19 sk. MY(o)lugia $: 00: 169$.

roroloplenraerate

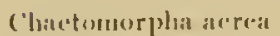

La!l wirlinm sp.

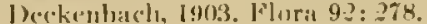


Cladophora sp.

Achlyoyeton entophytum

Sclıenk, 18.59. Bot. Zeit. 17: 399.

Sorokin, 1876. Ann. Sci. Nat. 6 ser. 4: 63, 1883, Arch.

Bot. Nord France 2: 44. 1889, Rev. Itycol. 11 : 139.

Martin, 19:27. Nycologia 19: 188.

Tokunaya, 1931. Trans. Sapporo Nat. Hist. Soc. 13: Q:อ7.

Bicricium trunstersum

Sorokin, 1883. Arelı. Bot. Nord France 2: 43. 1889, Rev. Atycol. 11 : 138.

Hy=ocytium proliferum

Walz, 1870. Bot. Zeit. 98: 553.

Hartin, 1927. Nycologia 19: 188.

'Tokunage, 1934. Trans. Sapporo Nat. Hist. Soc. 13: 298.

Sirolpidium Bryopsidis

Sparrow, 1936. Biol. 13ull. 70: 252.

Cladophora flavaescens

Achlyogeton sulinum

Dangeard, 193:. Le Bot. 24: 240.

Cladophora kuetzingiana

Myzocytium proliferum

Graff, 1928. Mycologia 20: 168 .

Cladophora laetevirens

Achlyogeton salinum

Dangea rd, 1932. Le Bot. 24: 240.

Bryopsis plumosa

Bryopsiduceae

Olpidium Bryopsidis

De Bruye, 1890. Arch. Biol. 10: 8.5.

Sirolpillium Bryopsidlis (de Bruyne)

Petersen, 1905. Overs. Ke. Dansk. Vids. Selsk. Forl. 13о. $5: 479$.

Sparrow, 1931. Dansk. Bot. Ark. 8, no. 6: 9. 1936, Biol. Bull. 70: 95:?.

\section{Jaucheriacene}

Vaucheria sp.

- Horomina glomerita

Scherffel, 19:5. A reh. Protistk. 52: 59.

Valkanov, 1931. Ilid. 73: 361. 1940, Hitl. 93: 940.

Vaucheria sessilis

Chytrillinm glomeratum

Cornu, 187\%. Ann. Sei. Nat. 5 ser. 15: 187.

Horomina glomerata (Cormu)

Fischer, 189?. Rahenhorst's krypt'fl. I, 4:64.

Zopf, 1894. Pliys. Morph. Med. Organismen 2: $\mathbf{4 6 .}$

Tokumaga, 1933. Trans. Sapporo Nat. Hist. Soc. 13: 26.

Vaucheria terrestris

Chytridium glomeratum

Cormu, 18\%'. Ann. Sci. Nat. 5 ser. 15: 187.

Joronina ylomerata (Cormu)

Fischer, 1892. Rabenhorst's Frypt*f. I, 4:64.

Zupf, 189. Phys. Jtorph. Nied. Organismen $2: 46$.

\author{
Characene \\ Charasp. \\ Layenibliopsis redurta \\ De Wilcknan, 1896. Ann. Soc. Belge Micro. 20: 109.
}

\section{PHAEOPHYCEAE}

\section{Eetocolpurene}

\section{Akinetospora sp.}

Eurychosmo dicksomii

Petersell, 1905. Overs, Kigl. Dansk. Vids. Selsk. Forlı. $5: 47 \%$.
Ectocarpus s]?.

Eurychasma dicksomii

Petersen, 1905, l.c., p. 466.

Jolnson, 1909. Sci. Proc. Roy. Dublin Soc. 12: 142.

Dangeard, 1934. Aum. Protist. 4: 69.

Petersenire andreei

Sparrow, 1934. Dausk. Bot. A rk. 8, no. 6: 17.

Ectocarpus confervoides

Rhizophilium dicksonii

Hauck, 1878. Oesterr. Bot. Zeitsclır. 28: 321.

Eurychasma dichsonii

Petersen, 190.j. Overs. Kgl. Dansk. Vids. Selsk. Forl. $5: 477$.

Ectocarpus crinitus

Rhisophidium dicksonii

Hauck, 1878. Oesterr. Bot. Zeitschr. $98: 321$.

Wriglit, 1879. Trans. Roy. Trisl Aead. $26: 369$.

Ectocarpus sandrianus

Eurychasma alicksonii

Petersen, 1905. Overs. Kgl. Dansk. Vids. Selsk. Forh. 5: $47 \%$.

Ectocarpus granulosus

Rhizophidium theksonii

Wriglt, 1879. Trans. Roy. Irish Acad. $26: 369$.

Eclocarpus sandrianus

Eurychasma dirksonii

Petersen, 1905. Overs. K̈gl. Dausk. Vids. Selsk. Forl. 5: 477 .

Ectocarpus siliculosus

Rhizophidinm dicksonii

Rattray, 1884. 'Trans. Edinburgh Roy. Soc. 32: 589.

Petersenia andruit

Sparrow, 1936. Biol. Bull. $70: 2+5$.

Pylaiella littoralis

Rhizophitlium thichsonii

Wriglit, 1879. Trans. Roy. Irish Acad. $26: 369$.

Wille, 1899. Vils. Selsk. Matl.-Nat. Klasse I, 3: 2.

Lowentlal, 1905. Arch. Protistk. 5: 925.

Eurychasmu dirksonii

Petersen, 1905. Overs. Kigl. Dansk. Vicis. Selsk. Forl. $5:+60$.

Striaria attennata

Rhizophidium tichsonii

Wright, 1879. 'Trans. Roy. Irish Aead. $26: 369$.

Hauck, 1878. Oesterr. Bot. Zeitschr. 28: 3?1.

Striaria attenuata var. tragilis

Olpillinm dicksmii var. Strinrine

W'ille, 1899. Vicl. Selsk. Matl.-Nat. Kilasse T, 3: ?.

Stictyosipbon corbierei

Eurychasmo dichsonii

Dangeard, 1934. Ann. Protist. 4: 69.

Stictyosiphon tortilis

Eirychasma alirkanii

Petersen, 1905. Overs, Kgl. Dansk. Vids. Selsk. Forh. $5: 4 \pi$.

\section{RHIODOPHYCEAE}

Crimiarpare

Callithamnion corymbosum

Pleotrachelus lobatus

P'etersen, 1905. Overs. Kgl. Dansk. Vids. Selsk. Forl. $5: 460$. 
Callilhammion hookeri

Prourarhelus dobalus

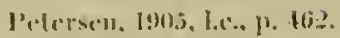

Callilhamuinn rosioum

l'elerseniol hobuta

Sipurrow, 1934. Biol. Bull. 70: 24.

Cогынiиm sp.

l'ontisma loupenidionides

l'etersen, Imn.i. Overs. Kipl. Dansk. Vids. Sclsk. Furh. 3: $1+3$.

Plontraclelus (1'etersenia) pollegester

sparrow, 1933. Dansk. J3ot. Ark. \&, no. 6: 15.

Coramium neanthemotum

Chylridium temifurien.

Magnus, lisiza. Silah. Gesell. Val. Jreunde. Berlin

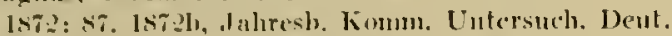

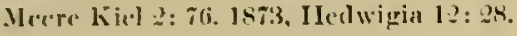

Ceramium diaphanum

Pemfisma lournieliniels: sinurraw, i936. Biol. Bull. $70: 252$.

linruchusmidium tumifuciens sparrow, 1936i. l.c.. p. 241.

pererseniu sp.

Sparrow, 19:36. 1.e., p. 243.

Ceramium flabelligerum

Chutrialium /umifucions

i]agnus, 167zit. Sitzh. Gesell. Nal. Frennde Berlin

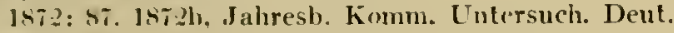
Meere Kiel 2: 76. 1573, Hedwigia 12: 98.

Olprilium tumifaciens. Fincher, 1892. Rabenhorst's Krypt'fl. I, t: 27.

liurychasmidium Iumifaciens

Sparrow, 1936. Biol. Bull. \%0: 211.

Coramium fructiculosum

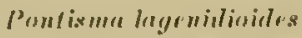

Sparrow, 1931. Dansk. Bot. Ark. 8, wo. 6: 11.

Crrunium rubrum

Pontisma layenirlinirles

Peternen, 190.j. Orers. Kgl. Dansk. Vicls. Selsk. Forì. j: 1 : $: 2$.

Pleotruchelus pollegenter

Petersen, 190.5, l.c., p. 462.

Ceramium tenuissimum

l'anfixma lagenidionides

l'etersen, 190:s, l.c., j. 182.

Sirospora interrupta

I'rersoria lobata

loeldmann, 1910. Bull. Soc. llist. Nat. Afrique Nord $31: \tau 2$.

Spermothamnion reperms

leetersonich lobuter

Spяrrow, 1931. 1)insk. Bot. Ark. 8. no. 6i: 13.

Sipuruothannion lurneri

Plestrachelus lestretus

I'eternen, 1905. Overs. Kgl. Dansk. Viuls. Selsk. Forl. ij: 160 .

\section{lihorlymeniucrote}

I Ialesaceron rancentaceum

liuryehresma nurculus

l'ceterwn, 190.j, l.c., p. 1\% .
Khudmenin palmatio

linrychersme sacerulus

Pelersen, 1905, I.c., ]1. 1.77.

Rhorlophyllidinerese

Cystochonium jurpurascens

Myrhosorus marinus

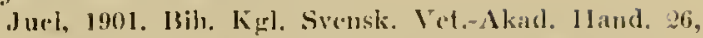
afol. III, Ho. IH: I I. I901, Rev. Iyeol. 21: 111.

\section{BSIROPHY'TA}

\section{JISI'TICIAIS}

Rirciucuee

Riecia sp.

Olpuiliopsis Rireriof

Du Plessis, 1933. Ann. Bot. 17: 7101.

Mnsi

Unidentified moss sprecies

Lregenidium elliplienm

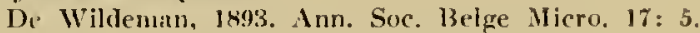
1893, Jour. Roy. Nlicro. Soc. 1893: 765.

\section{SPERMATOPHY̌TA}

\section{GINNOSPERIIAE}

Pinacere

Ahies canadensis

Lregenirlium j!ygmacum

Karling, 19.11. Nycologia $33: 3.28$.

Pinus sp.

Lagenidium pygmafenm

Sehultz-Danzig, 19:3. Schr. Sïssw.-und Jeerest. 11: 180.

l'inus aust riacen

Lagenilium lygmer'um

\%opf, 188т. Abh. Nat. Gesell. Halle 17:97.

Karling, 1911 , 1.c., p. 3.j8.

l'inus austriaca var. nigra

Letefenidium l'!!!morum

Karling, 19ii, l.c., pr. 3.58.

l'inms bituksiana

Lugenidium pygmarom

Katrling, 19:1, l.c.. 1).3.5.

Pinus densifora

Layf nillium py!muermm

harling, 1911, l.e., p. 3.5s.

l'imus laricio

Lergrnidlinm l!y!lmarnm

\%opf, 188\%, 1.c.. ]. 9\%.

Pinua pallasiana

Lanenidiam py! mar "m

kopf, 18st, I.c., 1.97.

P'inus sI robus

Lat) widium j"yymarum

Karling, $1911,1 . c^{\circ}, \mathrm{p} .3 .5 \mathrm{x}$. 
Pinus sylvestris

Lryenidiam lygmoram

Zopf, 1887. Abl. Nat. Gesell. Halle 17:97.

Karling, 1941, l.c., p. 358. 1941 , Torreya $41: 108$.

Pinus thunlyerghii

Laegenidium pygmentm

Karling, 19+1. My cologia 33: 358 .

Unidentified conifer pollen grains

Lagenidium l'ygmaeum

ilaurizio, 1895. Jahrsl. Nat. Gesell. Graübundens $39: 11$.

De Wildeman, 1895. Ann. Suc. 13elge Micro. 19:68.

Petersen, 1909. Bot. 'Tidsskr. 29: 101. 1910, Ann. Nycol. $8: 537$.

\section{ANGIOSPERMAE}

\section{Gramineae}

Agrojyron repens

Lagenu rudicicele

Vanterponl and Ledingham, 1930. Canad. Jour. Res. ?: 177.

1ruscott, 1933. Hycologia $\$ 5: 263$.

IJordeum vulgare

Lreyena radicicola

Vanterpool and Ledingham, 1930, l.e.

Saccharum officinarium

Chytridsp.

Carpenter, 1940. The Ilawaian I'lanter's Record 1:44.

Secale sereale

Lugenu rulicicolu

Vanterpoul and Ledingham, 1930, l.c.

'T'riticum aestivum

Lesence radicicula

Vanterpool and Ledingliam, 1930, I.c.

'Triticum durwm

Lugenu radicicola

Vanterpool and l,edingham, 1930, l.c.

7ea mays

Lugenu melicicolu

Vanterpool and Ledinglam, 1930, l.c.

Other wild grasses

Lugena rulirirola

Truscott, 1933, l.c., 1. 263.

\section{Elmucerte}

Uhus anericaua

Curpenterollo molinere

Tehon, L. R., and 1I. A. Harris, 19H1. Mycologria 33: $1 \geqslant 8$.

\section{Sulunacue}

Nicotiana sp. (?)

Myzorytium sp. (?)

Preissecker, 1905. Faclıl. Nitteil. Oesterr. Tabakregie 5, heff. $1: 3$.

\section{Curyouhyllacene}

Stellaria mudia

Myzueytirnm sp. (?)

Burreft, 1935. Phytopatl. 25: 898.

\section{ANIMALS}

\section{INFUSORIA}

Vorticella sp.

Éctrogella perforans

Sparrow, 1936. Biol. Bull. 70: 211.

Vorticella microsuma

Myzocylium sp. (?)

Stein, 1851. Zeitschr. Wiss. 7ool. 3: 176. 1854, Die Infusionsthiere und ihre Entw. Leipzig.

Vorticella nebulifera

Myzocytim s]). (?)

Steill, 1859. Der Organismus der Infusionsthiere. I abt., p. 106.

Philodina rosetía

Chytrillum eleyans

lerroncito, 1888. Centralbl. 13akt. Parasifk. $4: 295$.

Woronina eleyans

Fischer, 1892. Rabenhorst's Krypt'fl. I, 4: 66.

Unidenfified rotifers, eggs, and embryos

Putersenie sp. (?)

Sparrow, 1936. Biol. Bull. 70: 244.

Myzocytium zouphthorum

Sparrow, 1936. Jour. Linn. Soc. London kot. 50: 461.

Lnefrenitium vophilum

Sparrow, 1939. Mreologia $31: 531$.

Lreyend vophilum

Spar row, 1939, l.c.

\section{NEMATODA}

Anguillula sp.

Achlyogeton (?) rostratum

Sorokin, 18iti. Ann. Sei. Nat. 6 ser. 1: 64.

Myzocytium proliferum var. termicolum

Zopf, 188t. Nova Acta Kisl. Leop.-Carol. Deut. Atad. Nat. $47: 167$.

Myzocytium zermicolum

Fischer, 189\%. Rabenhorst's Krypt'fl. I, 1: 75.

1)angeard, 1906. I.e Bot. 9: 207 .

Birricium lethale

Sorokin, 1883. Arch. Bot. Nord France 2: 37. 1889, Rev. Mycol. 11: 135.

Protuseus sululiformis

Dangeard, 1903. C. R. Acad. Sci. Paris 136: 628, 1906. L.e Bot. 9 : 256 .

Rlublitis dolicluura

Protuscus subuliformis

Mauplas, 1915. Bull. Soc. I I ist. Nat. Afric. 6: 31 .

Proluseus subuliformis var. manpusii

Maire, 1915. llidl. 6: 50.

13habditis giardi

Protuseus subuliformis

Mlaupas, 1915, l.c., p. 31.

Protriscus subuliformis var. maupusii

Iaire, 1915, l.c., p. 50.

Rladsditis teres

Irotuseus subuliformis Natupas, 1915, l.c., p. 31.

J'otuscus subulifurmis var. manpresii Maite, 1915, l.c.. 1. 50. 
C'niskentilied nomaloudes

"y y:uryfium zurmirolum

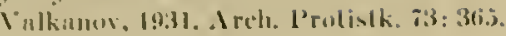

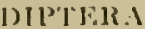

Mospuilo larsac

J.angrniliam! gigunteum

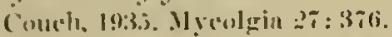

Mnllews. 1935. Jour. Flishn Milehetl Sci. Soc. jl: 309 .

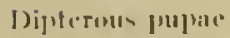

.y yrophenus urerninirns" Sparrow, 1939. Mycologia 31: 113.

Petels, 1910. The Naturalist mo. 995: bs.

Futemolhthere (Tarirlium) relirnlatu

l'eteh, 19:39. 'Trams. 13rit. Myeol, Soc, $2: 3: 1: z$.

\section{(U).FOI'TEMA}

Acarlhonomus granclis

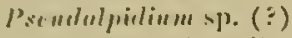

Krafka and Jiller. 19:6. Ann. Entmol. Soc. of America 19: 461.
Anisplia austrikes

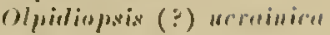

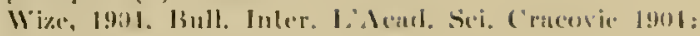
713.

Cleomus pumetivent ris

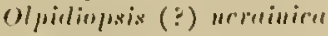

Wize, 1901. l.c... 1). 71:3.

\section{CIISTACLAR}

Cychuses sp.

bilustulidinpsis chutloni

Sigut, 1931. C". R. Soc. 13iol. 108: 37 .

D) (x)lune sp.

Lagenidium giganterm

Conch, 193.). 1lycologia $27: 376$.

Enidentified coprepords

Leryenidium !iguntenum

Couch, 1935, l.c., p. 376.

Callinectes sajudus

Lengunilinm Cullineress

Couch, 19 thatour. Flisha Mitchell sici. Soc. 5s: 1.58. 


\section{SPECIES INDEX}

Achlyogeton, 94

cntophytum, 9.4, 96 rostratum, 96

salinum, 96

Aphanomyeopsis, 28 bacillariacea rum, 30

Blastulidiopsis, 58 chattoni, 58

Diploplyysa, 50 elliptica, 50 Saprolegniae, $\mathbf{t} 1$ schenliana, 48

Eetrogella, 17 bacillariacearum, 20 Gomphonematis, 21 Licmophorae, 22 monostoma, 21 perforans, 21

Eurychasma, 2:2 diclisonii, 23 sacculus, 24

Euryelıamidium, 24 tumifaciens, 26

Lagena, 90 oophilum, 83 radicicola, 92

Lagenidiopsis, 71 reduct $a, 81$

\section{Lagenidium, 71} americanum, 77 brachystomum, 82 Closterii, 80 Cyclotellae, 82 ellipticum, 80 enecans, 78 entophytum, 77 giganteum, 8: gracile, 79 intermedium, 80 marchalianum, 81 Oedogonii, 81 oophilum, 83 papillosum, 77 pygmaeum, 78 rabenhorstii, 77 reductum, 81 sacculoides, 81 syncytiorum, 79 zopfii, 79 sp.. 83
Mitochytridium, 98

ramosum, 98

Myzoeytium, $8: 3$

globosum, 86

irregulare, 88

lineare, 88

megastomum, 89

polymorphum, 89

proliferum, 86

zermicolum, 88

zoophthorum, 89

sp.. 89,90

Olpidiopsis, 31

Achlyae, 16

andrćei, 51

Aphanomycis, 47

appendiculata, 51

brevispinosa, 48

'urvispinosa, 48

echinata, 1

elliptica, 50

fibrillosa, 50

fusiformis, 45

fusiformis var., Oedogoniarum, 51

gracile, +7

incrassata, $4 \mathrm{t}$

index, 4.5

irregularis, 14

luxurians, 47

major, th

minor, 45

Oedogoniorum, 51

parasitica, 48

Pythii, 47

Ricciae, 52

Saprolegniae, 41,44

Saprolegniae var.. leavis, th

schenliana, 48

sorolinii, 50

Sphaeritae, 5 t

spinosa, 45

ncrainica, 52

z'arians, $\$ 6$

zexans, t.t

sopfii, 50

Petersenia, 66

andréei, 51

lobata, 68

sp.. 68

Pleoeystidium, 48

parasiticum, 18

Pontisma, 66

lagenidioides, 66
Protaseus, 96

subuliformis, 97

subuliformis var., maupasii, 97

Pseudolpidium, 52

a phanomycis, 47

deformans, $5+$

fusiforme, 45

Glenodinianum, 54

gracile, +7

incrassatum, 4

Pythii, t7

Saprolegniae, 1

Sphaeritae, 54

stellatum, 46

sp.. 55

Pseudolpidiopsis, 50

appendiculata, $5 \mathrm{I}$

elliptica, 50

fibrillosa, 50

parasitica, 18

schentiana, 18

zopfi, 50

Pseudosphaerita, 55

Euglenae, 56

radiata, 56

Pyrrlosorus, 10

marinus, 10

Pythiella, 58

zernalis, 59

Resticularia, 92

boodlei, 93

nodosa, 93

Oedoyonii, 93

Rhizomyxa, 90, 98

hypogea, 90

Rozellopsis, 12

inflata, $1+1$

septigena, 16

simulans, 16

zeaterhouseii, 1.

Sirolpidium, 63

Bryopsidis, 66

Lagenidioides, 66

Woronina, 6

aggregata, 8

asterina, 10

elegans, 8

glomerata, 8

polycystis, 7

polycystis rar.. scalariformis, 7 


\section{SI B.JE(C'I IXI)H.}

Alics, is

Ichlya. . 10:3. $106 \mathrm{i}$

Acrisicule, 7

Icrosiphonia, j]

Igrop!yron, !)!

Alinetos pora, 2t

Alluminale'ale. 106

Imphara, is

Amylophas/ns, 103

Anisplia, s:2

Incylistes, 89.93. 10.5

Ancylistiles. 93. 10 1. 106

Androgenesis, to

Anguillula, !) \&.96;

Intleridia. 38. 72. 76.85

Iphrlidiopsis, 103

Iphaniste's, 80

Iphanomyces, +7. 103

- Iplanes, 3:3

Arthrodesmus, 86

Iz'ma, !)?

Bicricium, 86, 85,94

Biological races, 44,47

Blastorladialc's. 106

Blastulidium, 58

Boll IVecril. 55

Bromus, !2

Bryopsis, 66

Callithamnion, 68

Carpenterella, 60

Catemaria, 20.98

Centrosomes, :38

Cephaluleus, ys

Ceramium, 2t. 206, 66

Ceratium, .ot

Chactomorpha, 83

Chara, 79, 81

Chlamydomonas, 56.113

Chromosomes, 12, 38

Chytridiales, 1.2, 18, 100, 102, jo.j. 107

Chytridium, 8.21. 26

Cladoclivtriaceae. 98

Clatopliora, 6f5, 79, 88,9 1

Cleaviege. 31, 36, 7t, 10\%

('lounus, 5')

C'losterium, 80, 82. 86;.88,89,97

Coccunema, 78

Copreput. 8:3

Cosmarium, 86, 97

Crustaceate, 119

Cryptomenas, 58

Cyclops, 58

Cyclofilla, 82

Cymatoplenra, 78

Cymbanche, 20

Cymbella, 30.78.82

Cystoclomium, 10

Cysturpores, 30, 36
Crstosorus, 7, 8, 10

Daphne, $8: 1$

l) ietyuchns, 3:1, +1,103

Diplanetism, 17, 20, 21, 23. 28, $36.76 .94 .10 \% .106$

Diplogaster, 97

I) iuccism, 9:2

Docidium, !s

I) raparnaldia, ij

Ectocarpus, 23. 51

Fintomoplithorales, 93

Entomophthora, 5:

Epiplasm, 7:2

Epithemia, 30

Euastrum, 78. 80

Euglena, 55.56

Eurycliasmaceac, 17

Exospore formation. 13,11,39

Glenodinium, 5 t

Glycogen, 8

Gompleonema, 20, 22, 78, 82

Gymmococcaceat 7

Gymnococcus, 7

IIalosaccion, 2 .

Haplosynoccious, 10

Heterocont, 36.5 1,81

Heterogamy, 38, 39, 59, 71

Heterothallic, +0.70, 71

Homothallic, $40,70,71$

Hordenm, 92

IIydrodictyon, 79

Hypertrophy, ?.+

Isoachlya, 33. 11. 1.t

Isocont $10,28,31,36,92$

Isogamy, 38, 92.96. 105. 107

Karyogamy. 39, 10

Labyrintbula, 6.2

Lauderia, 2 1

Leptolegnia, 33.11

Leptomitaceae, $106 \mathrm{j}$

Licmophora, ㄴ1, 2쁘

Ligniera, fi. 100

L.yngl,ya, 93

Meiosis. 38

Meridon, $\geq 0$

Mesecarpus, 50,51.77.86

Micruasterius, 78. 86. 88

Monadincac, 100, 10

Monoecism, if

Monozoospore coltures, :32, t0

Mosquito. $8: 3$

Mosses. 80

Mongeolia, 50, 77,80

Mrxochlytribliales, 1,101

Myozoidia. 6,101

Vazirula, 78

Fematoules. 83.88.96

"Set sporangium," 23

Nitclla, 7!

Sitzschia, $20,30,82$
Nuclear division, 38

Octomy.xa, (i, 12, 100

Otologonium, 51,77.79, 80,81, 90, 96

Olpidiaceac, 17, 10:3

Olpidium, 20, 2:3, 51,54,6.3

Ooplasm, 76

Parthenogenesis, $38,76,78,79$

l'enium, 83

l'eriplasm, 38, 76, 105, 107

Peronosporaceite, 100, 103, 106. 107

l'hilorlina, 8

'Phytophthora, 12, 15, 16

Pilobolus, 8

Pinnularia, 20,30

Jinus, 78

Pithophora, 79

Plasmodiophorales, 6, 7, 98, 100, 101,107

Plasmodium, 3, 5, 6, 7, 8, 10,11

Plasmogamy, 39, 40

Pleolpirimm, 12, 14

Pleurosigma, $\geq 0$

Penrolaenium, 30, 80.88

Pleotrachelus, 20, 20,51,68

Poa, 90

Polymy.xa, 6.100

Pringsheimella, 7, 101

Proteonyas, (i. 100, 101

Protoachlya, 33. \$1

Pseudolpidiaceae. 2

I'sendospora, 103

Psendosporopsis, $10: 3$

Pylaiella, 23

Pytliaceae, 1, 105. 106

Pythiogeton, 103, 106

I'ythium, 14, 36. 10. 47, 59, 77. $10 \%, 105,100 \mathrm{i}$

Rhabditis, 97

Rhizophidium, 22:2

Rllizidiomyces, 10 ;

Rhorlymenia, 2t

Rircia, 52)

Rotifer, (is, 83, 89)

lioz=lla, 12, 1:3.1\%.101

Saprolegnia, 7, 16, 18, 11, 14. 103, joc;

Selizogony, 6, $, 1,101$

Secale, y)

Septolpidimm, 9.

Six determination, 39,10

Sixuality, 30. 10

Seirospora, 68

Simapsis, 9:2

Simrolpidium, 12

Surus. 2. 6. 7.8. 10

Sphaerita, 54.55. 56;

Spermothamnium, 18

Spirngyra, 50, 75, 78, 79, 89 
Spirotaenia, 89

Spongomorpha, 51

Sporangiosorus, 5, 6, 7, 8

Spore mother cells, 12, 101

"'Spreizapparat," $18,19,22$

Staurastrum, 115

Stauroneis, 78

Stellaria, 90

Stict yosiphon, $2+1$

Stigeoclonium, 79,97
Striaria, 23

Striatella, 21

Surirella, 30

Symbiosis. 41

Synchytriaceac, 1,18

Synchytrium, 18

Synedra, 20, 21, 82, 89

T'etramyxa, 12

"Theilplasmodien," 7

"'Tinsel"' flagella, 95, 105, 107
Tobacco, 90

Tolypothrix, 93

Tribonema, 50

Triticum, 92

Iraucheria, 8

Vesicle, 70, 73, 77, 78, 8ł, 86, 88

Irorticella, 21, 89, 90

Zea, 92

Zygnema, 77, 86

Zygomycetes, 93,107

\section{AUTHOR INDEX}

Archer, $30,+1$

Atkinson, 77, 78, 79, 100, 106, 107

Barmes. $10^{\circ}$

Barrett. 38, 39, 40, $41,44,47,90$

Behla, 41

Berdan, 70, 89

Bessey, 100, 105, 106

Bisby, 17, 50

Borzi, 71,90, 98

Braun, 1, 11

Brodsky, 5.j

Butler, 1 f, 15, 32, 39, $47,50,98$

Carpenter, 60

Carter, 78

Cavers, 100,106

Cejp, 45, 56, 77,80, 88, 89

Chatton, 55

Chandhuri, 88

Cienkowski, 1, 15

Clements, 105

Cocconi, 77

Coker, 17, 28, 36, 41, 4,105

Constantincanu, $36,41,41,45,50,77,88$

Cook, 6, 7.71,76, 79, 100, 106

Cornu, 2, 6, 8, 31, 41, 45, 47. 79, 96

Conch, 7. $+1,58,59,74,80,81,82,93,98,100$

Cramer, 26

Dangeard, $7,31,41,77,54,55,58,86,92,96,97,98$, 102. 106

Davis, 41

De Bary, 100, 102, 105

De Bruvne, 66

Deckenbach, 83

Dielıl, $\$ 1$

Dodge. $71,100,105$

Domjan, 20, 77

Du Plessis, 36, 52

Feldmann, 68

Fisch, $31,32,48,50$

Fischer, 4, 6. 8, 16, 24, 31, 32, 4. 45, 48, 88, 93, 96

Fitzpatrick, 93,96i,97, 100, 102, 106

löke, 21

Fritscl, 93

Gaïmann, 7 1, 100, 105

Gill, 20

Gilman +1

Graff, $41,77,88$
Gran, 24

Gwynne-Vaughan, 102

Harper, 17

Harris, 60

Hartog, 7

Harvey, 2.t, 41

Hauck, 23

Jahn, 55

Johnson, 23

Jokl. 51,52

Juel, 10, 11

Karling, 6, 1:2, 13, 14, 21, 78, 79, 100

Klehahis, 79

Krafka, 55

Kiitzing. 2.5

I.agerheim. 51

Ledingham, 90, 92, 100

I.ind, 88

I.indstedt, 86

L.otsy. 2, 100

Lowenthal, 22, 23

Magnus, 22, 2.4, 25,26

Maire, 100

Maneval, 41

llartin, 9.

Iatthews, $17,28,45,83,105$

Maupas, $89,96,97$

Maurizio, $7,16,14,78$

McLarty, 32, 3., 38, 39, $40,42,46$

Mez, 102

Miller, 5.5

Minden, 2, 1. 16, 15, .7 , 50, 51, 102, 106

Mitchell, 31, 55

Iundkur, 88

Nägeli, 1, 1

Nägler, 55, 56

Nicholson, 6, 7

Perroncito, 8

Petch, 52

Petersen, 7. 17. 21, 22, 24, 26, 41, 4t, 51,63, 68, 78, $88,102,10 \%$

Pfitzer, 20

Preissecker, 90

Pringsheim, 1.20, 11, 77, 105

P'umaly, 56

Ramsbotton, $7,20,26$

Rattray, 23 
Krillsch, 2. 332. H. 1.5

Sicosirilo. !):3

Silwimla. 4.). Hi

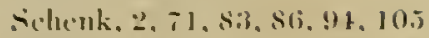

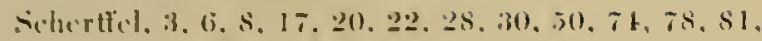
S.2. $100,102,106$

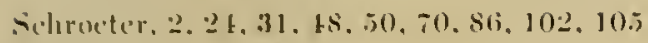

sionltz-I)amziç. - s

sihwarzo. 17. 11

sirlinow. $5+.5 .5 .7 ! .81$

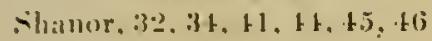

sicar. 10.5

sigurot. js

skiortzow,, 8 s. 89, 93

sultl, $+.20,20$

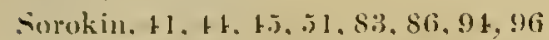

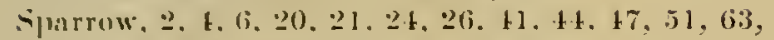
(iti. \&3. 89), 10 t

situin. $5(0,58,8 !)$

iwingle. 17

"livel. 100, 102, 105

rilion. 60
'Thompsom, s8, s?

'Tison, 100

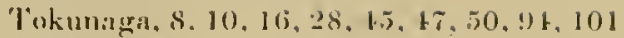

'Trument, (9):

'Turmer. 90

Vilknmex, 8, 77, 88

VanIeurek, 20

Vinterpool. 90,92

Vuillemin, 2. 100

11 il $\%, 2,8(j, 10.5$

Hiterhouse, 16

IVest. 28,30

Vieston, ?

IVettstein, 100, 10.5

11hitlen, 32, 17,48

Wildeman, 20, 26, :32, 50, $71, \tau 7,78,80,81$

Wille, 23

Winge, 12, 100

Wizc, 5:2

IIolk, 96

II right. 23

Zupf, $, 2,6,7,8,17,32 .+8,50,76,78,86,100,106$ 

, 

